FACULDADE DE EDUCAÇÃO

UNIVERSIDADE DE SÃO PAULO

MARIA NIZETE DE AZEVEDO

\title{
MEDIAÇÃO DISCURSIVA EM AULAS DE CIÊNCIAS, MOTIVOS E SENTIDOS NO DESENVOLVIMENTO PROFISSIONAL DOCENTE
}

SÃO PAULO

2013 


\section{MARIA NIZETE DE AZEVEDO}

\section{MEDIAÇÃO DISCURSIVA EM AULAS DE CIENCIAS, MOTIVOS E SENTIDOS NO DESENVOLVIMENTO PROFISSIONAL DOCENTE}

Tese apresentada à Faculdade de Educação da Universidade de São Paulo para obtenção do título de Doutor em Educação.

Área de concentração: Ensino de Ciências e Matemática

Orientadora: Profa. Dra. Maria Lucia Vital dos Santos Abib

São Paulo 2013 
AUTORIZO A REPRODUÇÃO E DIVULGAÇÃO TOTAL OU PARCIAL DESTE TRABALHO, POR QUALQUER MEIO CONVENCIONAL OU ELETRÔNICO, PARA FINS DE ESTUDO E PESQUISA, DESDE QUE CITADA A FONTE.

Catalogação na Publicação

Serviço de Biblioteca e Documentação

Faculdade de Educação da Universidade de São Paulo

371.121

A994m
Azevedo, Maria Nizete de

Mediação discursiva em aulas de ciências, motivos e sentidos no desenvolvimento profissional docente / Maria Nizete de Azevedo; orientação Maria Lucia Vital dos Santos Abib. São Paulo: s.n., 2013.

272 p. ils.; tabs.; anexos; apêndices

Tese (Doutorado - Programa de Pós-Graduação em Educação. Área de Concentração: Ensino de Ciências e Matemática) - - Faculdade de Educação da Universidade de São Paulo.

1. Formação de professores 2. Aprendizagem 3. Desenvolvimento profissional 4. Ciências (Ensino) 5. Mediação discursiva I. Abib, Maria Lucia Vital dos Santos, orient. 


\section{FOLHA DE APROVAÇÃO}

Maria Nizete de Azevedo

Mediação discursiva em aulas de ciências: motivos e sentidos no desenvolvimento profissional docente

Tese apresentada à Faculdade de Educação da Universidade de São Paulo para obtenção do título de Doutor.

Área de Concentração: Ensino de Ciências e Matemática

Aprovado em:

Banca Examinadora

Prof. Dr.

Julgamento:

Prof. Dr.

Julgamento:

Prof. Dr.

Julgamento:

Prof. Dr.

Julgamento:

Prof. Dr.

Julgamento:
Instituição:

Assinatura:

Instituição:

Assinatura:

Instituição:

Assinatura:

Instituição:

Assinatura:

Instituição:

Assinatura: 


\section{AULA DE VOO}

$O$ conhecimento

caminha lento feito lagarta

primeiro não sabe que sabe

e voraz contenta-se com o cotidiano orvalho

deixado nas folhas vívidas das manhãs.

Depois pensa que sabe

e se fecha em si mesmo:

faz muralhas, cava trincheiras, ergue barricadas.

Defendendo o que pensa saber levanta certeza na forma de muro, orgulhando-se de seu casulo.

Até que maduro, explode em voos rindo do tempo que imagina saber ou guardava preso que sabia.

Voa alto sua ousadia reconhecendo o suor dos séculos no orvalho de cada dia.

Mesmo o voo mais belo descobre um dia não ser eterno.

É tempo de acasalar: voltar à terra com seus ovos à espera de novas e prosaicas lagartas.

O conhecimento é assim: ri de si mesmo e de suas certezas. É meta da forma metamorfose movimento

fluir do tempo que tanto cria como arrasa

a nos mostrar que para o voo é preciso tanto casulo como asa.

Mauro Iasi 
Ao meu pai Cantídio, aos meus irmãos Carlinhos e Dio (em memória) porque são inesquecíveis.

À minha mãe Zenaide, à minha irmã Gracinha pela alegria de tê-las em minha vida e pela segurança que me transmitem todos os dias.

Para Téo, por significar o maior encontro de minha vida; Aos frutos desse encontro: nossas filhas Kena e Anana e nossa neta Luna, não apenas pela alegria que refletem em nossas vidas, mas porque concretizam a nossa continuidade. 


\section{Agradecimentos}

À querida Prof. ${ }^{a}$ Dra. Maria Lucia Vital dos Santos Abib, minha professora, orientadora e, para sempre, amiga. Muito obrigada pelo acolhimento desde o inesquecível primeiro encontro, marcado como o início de uma caminhada conjunta partilhada com afeto, dedicação, confiança e dignidade.

Ao Prof. Dr. Manoel Oriosvaldo de Moura pelas contribuições à minha formação como pessoa humana e pesquisadora e pelas preciosas orientações no exame de qualificação.

Ao Prof. Dr. Marcelo Giordan pelas portas que se abriram com os estudos em sua disciplina e por suas contribuições no exame de qualificação.

Aos professores Dra. Vanessa Dias Moretti, Dr. Cristiano de Mattos, Dr. Manoel Oriosvaldo de Moura e Dra. Lucia Helena Sasseron pelas grandes contribuições na defesa.

Às professoras Dra. Anna Maria Pessoa de Carvalho e Dra. Lucia Helena Sasseron por contribuírem com a formação das professoras e coordenadoras dos anos iniciais na EMEF Candido Portinari e pelo tanto que valorizam a escola pública como um lugar de aprendizagem.

Agradeço aos colegas do grupo de pesquisa pelas valiosas contribuições e compreensões compartilhadas.

Muito obrigada às amigas e parceiras de estudos e pesquisa Beatriz e Marta, pelo carinho e cuidado com que leram muitos dos textos que compõem este trabalho.

Não encontro palavras para agradecer à Verônica, nome que identifica a professora que generosamente participa desta pesquisa. Muito obrigada a essa minha amiga e parceira de trabalho pela aprendizagem mútua e por sua imensurável contribuição a esta pesquisa.

Milhares de palavras seriam insuficientes para expressar a minha gratidão às professoras da EMEF Candido Portinari, parceiras e amigas de uma longa trajetória de docência construída conjuntamente. Muito obrigada pelos motivos e sentidos partilhados e pelo tanto que aprendo com vocês. Esse agradecimento se estende às professoras que compuseram o quadro docente da escola e, que hoje, estão em outras unidades escolares ou se aposentaram.

Agradecimentos à equipe gestora da EMEF Candido Portinari pela compreensão e apoio.

Obrigada ao grupo do "Observatório da Educação" pelas boas discussões, muitas delas acolhidas como subsídios teóricos à escrita deste trabalho.

Agradeço aos familiares, amigas e amigos por compartilharem comigo, presencialmente ou virtualmente, dos pequenos e grandes momentos de minha vida. Muito obrigada às amigas e aos amigos presentes na defesa, cujo apoio foi imensurável.

Agradecimentos especiais ao meu companheiro Téo pelas boas conversas sobre o meu objeto de pesquisa e, principalmente, pela compreensão e tolerância às turbulências dos últimos momentos da escrita. 


\section{RESUMO}

A presente pesquisa aborda como temática central o desenvolvimento profissional de professores dos anos iniciais de escolarização, relativo ao ensino de ciências. Desenvolveu-se em uma escola da rede municipal de ensino da cidade de São Paulo, tendo como base uma formação contínua em serviço orientada pela realização de atividades investigativas de ensino. A partir de referenciais teóricos da perspectiva histórico-cultural, o desenvolvimento profissional é abordado como um processo desencadeado pela docência, concebida como atividade, e como tal, mediada por ações coletivas e colaborativas. Esta investigação problematiza a relação entre ensinar ciências e aprender a ensinar ciências, a partir da seguinte questão: o que a mediação discursiva docente pode mostrar sobre o trabalho docente e desenvolvimento profissional de professores dos anos iniciais que ensinam ciências sob orientação investigativa? Trata-se de um estudo de caso, com aproximações à análise microgenética. A análise privilegia a atividade docente em sala de aula de uma das professoras do coletivo da escola, realizada mediante a configuração de suas mediações discursivas. Os resultados mostram o desenvolvimento profissional como um contínuo processo de realização de motivos e objetivos pelo professor, e de subsequentes atribuições de sentidos, potencializados por situações de aprendizagem oriundas de necessidades formativas que emergem do movimento dialógico discursivo em sala de aula. Conclui-se que o desenvolvimento profissional do professor está relacionado ao conteúdo de seus motivos e sentidos, à capacidade de reversibilidade dos modos de mediação por ele adotados para realizar os seus objetivos e à dimensão coletiva e colaborativa de sua docência. Desse modo, a pesquisa pode contribuir com reflexões no campo teórico/prático da formação de professores no ensino de ciências, não apenas por evidenciar realizações e necessidades docentes em sala de aula, mas por destacar a construção da docência na amplitude da práxis, como condição essencial para o desenvolvimento profissional.

Palavras chave: Formação de professores; aprendizagem e desenvolvimento profissional docente; ensino de ciências nos anos iniciais; mediação discursiva; motivos e sentidos docente. 


\begin{abstract}
The theme of this research is the professional development of first school years science teachers. It has been developed in a school of the São Paulo municipal teaching network based on continued education on site and supported by investigative teaching activities. Based on theoretical references that have a historic-cultural perspective, professional development is approached as a process triggered by the teaching activity and, as such, affected by collective and collaborative actions. This investigation discusses the relation between teaching science and learning how to teach science, and asks: what can the teaching discourse mediation show about the teaching activity and the professional development of first years' science teachers that teach using an investigative approach? This is a case study that approximates microgenetic analysis. This analysis focuses on one of the school teachers' teaching activity in the classroom and was conducted through the configuration of her discourses. Results present professional development as a continuous process through which the teacher accomplishes motives and objectives and, subsequently, assigns meanings that are strengthened by learning situations deriving from educational requirements that arise from the discourse/ dialogue movement inside the classroom. It is possible to conclude that the teacher's professional development relates to the content of her motives and meanings, to her capacity of reversing adopted mediation modes to achieve her objectives, and to the collective and collaborative dimension of her teaching. Accordingly, this research may contribute to reflections on the theoretical/practical field of science teachers' education, not only because it evidences teaching accomplishments and requirements in the classroom, but because it emphasizes the construction of teaching, considering the praxis as the key condition for professional development.
\end{abstract}

Key words: Teachers education; learning and professional development of teachers; first years science teaching; discourse mediation; teachers' motives and meanings. 


\section{SUMÁRIO}

Introdução

Capítulo I - Atividade humana, trabalho docente e desenvolvimento profissional

1.0 Trabalho e atividade humana - categoria fundante do materialismo histórico-dialético. 22

1.1 Sobre a Teoria da Atividade .28

1.1.1 Significado e sentido na Teoria da Atividade. 38

1.2 Trabalho, atividade e consciência e alienação .42

1.3 Sobre o trabalho docente 45

1.3.1 Espaços de construção de novos conteúdos ou sentidos para o trabalho docente .50

1.4 Trabalho docente, aprendizagem e desenvolvimento profissional docente 53

Capítulo II - Trabalho docente: linguagem como signo/instrumento de mediação e de aprendizagem docente em aulas de ciências .65

2.0 Mediação: conceito explicativo do desenvolvimento humano 65

2.1 Linguagem e palavra: gênese, conceito e função social 70

2.2 Linguagem e modos de mediação docente em aulas de ciências 77

Capítulo III - A pesquisa: contexto e metodologia 88

3.0 A escola e os processos formativos 88

3.0.1 Organização geral do ensino de ciências e estrutura das aulas de ciências 96

3.1 Metodologia da pesquisa 101

3.1.1 O problema, a unidade de análise e objeto da investigação .106

3.1.2 Sujeitos da pesquisa e os procedimentos para coleta de dados 109

3.1.3 A pesquisa como um estudo de caso com proximidades com a análise microgenética 
4.0 Procedimento de análise 114

4.1Eixo e estrutura da análise 116

4.2 Eis a narrativa: história da vida profissional - Professora Verônica 119

Capítulo V - A análise

5.0 Os dados analisados

5.1 Aula 01 - "Para cima e para baixo com o submarino"

5.2 Aula 02 - Roda de conversa: como resolvemos o problema do barquinho e por que conseguimos resolvê-lo? .156

5.3 Aula 03 - Roda de conversa; O que aprendemos sobre os dinossauros e a pré-história humana

5.4 Síntese: sobre as mediações discursivas docente 186

5.5.1 Mediações discursivas e o modo geral de ação da professora Verônica 186

5.5.2 Mediações discursivas e as comunidades vocais no sistema coletivo de atividade. 193

5.5.2.1 Multivocalidade da sala de aula

5.5.2.2 Processos formativos: grupo escola e parceria colaborativa com a universidade vozes virtuais em sala de aula

5.5.3 Mediações discursivas e o desenvolvimento profissional

5.5.3.1 A realização do objetivo/motivo docente culmina com a construção de sentidos favoráveis ao desenvolvimento profissional

5.5.3.2 Necessidades formativas e situações de aprendizagem da docência. 202

5.5.3.3 Indícios de desenvolvimento profissional 204

Capítulo VI - Conclusões e considerações finais .206

Referências bibliográficas 


\section{Introdução}

Anos de exercício profissional na escola pública somados a experiências no campo da formação contínua de professores nos aproximam da temática desta pesquisa. Compreender a relação entre aprendizagem da docência, desenvolvimento profissional e trabalho docente no processo de ensinar ciências nos anos iniciais de escolarização, constituiu-se como uma necessidade diante da busca por caminhos que conduzam à superação da reconhecida crise do ensino de modo geral, particularmente do ensino de ciências, no Brasil e em muitos outros países. Conhecer com mais profundidade necessidades, motivos e sentidos docentes que emergem dos modos como o professor articula ações e linguagem para mediar as relações discursivas em aula, podem nos aproximar do processo de desenvolvimento profissional docente e nos subsidiar com novas contribuições para as reflexões no campo da pesquisa em ensino de ciências e da formação permanente de professores.

Há algum tempo estamos nesse encalço. A presente pesquisa dá continuidade a estudos anteriores realizados em nível de mestrado (Azevedo, 2008), por meio dos quais investigamos como um processo formativo organizado por atividades investigativas de ensino, com pressupostos próximos a uma pesquisa-ação, contribuiu para a elaboração de saberes em ensino de ciências pelos docentes nele envolvidos. Os resultados mostraram que a elaboração de saberes docentes era proporcionada por situações de aprendizagem de cunho colaborativo criadas no âmbito da realização das atividades investigativas de ensino (pesquisa-ação). Além dessas contribuições, o trabalho mostrou a elaboração de saberes docentes relacionados a elementos indicadores de aprendizagem, como a auto-organização docente, a iniciativa ao estudo e à pesquisa, modos de se ensinar ciências sob orientação investigativa, e de articular esse ensino com o processo de alfabetização na língua materna, construção de práticas colaborativas na escola, entre outros.

No âmbito desses resultados emerge a necessidade de aprofundamento dos estudos acerca dos modos de aprendizagem docente e a relação dessa aprendizagem com a possibilidade de mudanças da prática em sala de aula. Quais elementos formativos apresentariam potenciais para diminuir a distância que há nessa relação? De modo mais claro: quais elementos formativos levariam professores a necessidades de mudanças em seus modos 
de ensinar? Seria a tomada de consciência sobre o seu próprio modo de ensinar? Seria o estudo teórico articulado à observação da prática? Como potencializar processos formativos realizados na própria escola para que questões dessa natureza sejam introduzidas nos grupos de trabalho? Muitas dúvidas lampejavam nossas mentes, cujas respostas ou parte delas apenas poderiam vir com a continuidade dos estudos sobre a aprendizagem desse mesmo grupo de professores em formação.

O processo formativo em discussão acontece na EMEF Candido Portinari, escola pública da rede municipal de ensino da cidade de São Paulo. Essa escola é considerada como um contexto escolar que guarda algumas peculiaridades, se comparado às características das escolas públicas de modo geral. A construção do seu laboratório de ciências, por exemplo, foi um dos marcos na história dessa escola (Azevedo, 2008). Em 1995, por iniciativa de um grupo de professores, do qual a pesquisadora compunha no papel de professora de ciências e coordenadora, e com recursos advindos da própria comunidade escolar, um banheiro desativado que servia de depósitos de móveis velhos foi transformado em um pequeno laboratório de ciências. A partir da efetivação desse projeto, instaura-se um processo formativo em ensino de ciências majoritariamente composto por professores dos anos iniciais, cuja singularidade é pontuada não somente por sua prática colaborativa, mas por se tratar de um movimento que nasceu dentro da escola, diante de necessidades identificadas pelo coletivo docente e por este construído e gerido. A continuidade e os resultados desse projeto são surpreendentes, pois, atualmente, esse laboratório é reconhecido não apenas como um amplo espaço físico bem equipado, mas, sobretudo, como um ambiente que reúne motivos de aprendizagem tanto para o professor como para os estudantes. A construção de uma concepção de ensino em ciências sob orientação investigativa inclui-se na história e na prática dos professores envolvidos com o laboratório de ciências.

Essa experiência gerou reflexões presentes no corpo de algumas pesquisas realizadas no âmbito da escola, como a supracitada (Azevedo, 2008) e a desenvolvida por Bezerra (2009), em nível de doutorado, com resultados que discutem o papel da escola na formação do estudante leitor, com destaque para as contribuições dos projetos realizados junto ao laboratório de ciências para essa formação.

Os resultados dessas pesquisas e sua divulgação trouxeram novas perspectivas para a escola e para as atividades formativas organizadas e realizadas a partir do laboratório de ciências. Uma delas foi a parceria colaborativa estabelecida entre a escola e o LaPEF 
(Laboratório de Pesquisas em ensino de Física - FEUSP) no período de 2008 a 2010 por meio do projeto intitulado "Aprender a ensinar e ensinar para que os alunos aprendam" (CNPq, $\mathrm{n}^{\circ}$ 471237/2008-6), envolvendo professores e alunos da escola dos anos iniciais de escolarização. Por um lado, a escola buscava meios que impulsionassem o processo de formação contínua de seus professores, por outro, a universidade pretendia testar em escolas públicas sequências didáticas em ensino de ciências, elaboradas por seus pesquisadores.

Os motivos da atual investigação são gestados nesse contexto formativo e se substanciam a partir de observações contínuas e participantes de aulas de ciências realizadas pela pesquisadora ao longo da sua atividade profissional como coordenadora e no próprio processo de coleta de dados para esta pesquisa. A centralidade nas questões referentes à linguagem, como modo de mediatização da comunicação e mediação das inter-relações discursivas, salta aos olhos e podem fornecer pistas para aprofundarmos e ampliarmos a nossa visão sobre a aprendizagem e desenvolvimento profissional docente.

O seguinte relato construído a partir do registro do diário da pesquisadora marca um desses momentos de observação de aulas, inesquecível para um pesquisador em busca de motivos especiais para seus estudos. Ele pode ilustrar e facilitar o entendimento de nossos propósitos:

Uma das professoras do coletivo docente ensinava a crianças de $1^{\circ}$ ano de escolarização (6 a 7 anos de idade) sobre o Sistema Solar. Para tanto, junto ao seu grupo de trabalho, planejou e desenvolveu uma sequência de atividades com pesquisas, experimentos e outras ações. Para finalizar o ciclo investigativo (assim denominado pelo coletivo), organizou uma roda de conversa no laboratório de ciências, adotando como modo de mediação a leitura de uma matéria da revista Recreio ${ }^{1}$, intitulada "Mudança no céu" que informava sobre o rebaixamento de Plutão, até então considerado um dos planetas do Sistema Solar, à condição de planeta anão. A leitura da matéria conduzia à conclusão de que Plutão tinha deixado de ser um planeta e estava "fora da turma". Imediatamente após a professora proferir tal informação, Gabriel, uma das crianças, levantou a sua mão, pediu a palavra e, impetuosamente, disse: "professora como pode ser? Não estou entendendo. Para onde levaram Plutão? Onde ele está agora?”. Reinou um clima de difícil descrição, de surpresa, risos e dúvidas. A professora retomou a sua mediação discursiva, e, uma vez com a posse da palavra, após indagar às outras

\footnotetext{
${ }^{1}$ Revista Recreio, $\mathrm{n}^{\mathrm{o}} 340$, setembro/2006
} 
crianças se elas haviam compreendido do mesmo modo, explicou para a classe qual fora a confusão de Gabriel. Entre uma palavra e outra, acompanhadas de gestos explicativos, foi tentando dirimir a dúvida de Gabriel, afirmando que tudo não passava de novos estudos e decisões de cientistas, em que Plutão, por suas próprias características diferentes daquelas dos demais planetas, havia deixado de ser considerado um planeta, mas que permanecia no lugar de sempre.

Perguntamos: é possível não se encantar pelo movimento discursivo que emana dessa simples conversação? Como não despertar interesse pelo estudo da linguagem, pelo modo como as palavras podem ser usadas pelos sujeitos em uma aula? Como afirma Bakhtin (2010, p. 117):

(...) a palavra é uma espécie de ponte lançada entre mim e os outros. Se ela se apoia sobre mim numa extremidade, na outra se apoia sobre o meu interlocutor. A palavra é o território comum do locutor e interlocutor.

Bakhtin nos fala da complexidade que se encerra no processo de comunicação, ampliado ao ser estabelecido com crianças em um contexto coletivo, como o é uma sala de aula. Mesmo no papel de professora, digamos assim, tradicionalmente e hierarquicamente possuidora do poder sobre o discurso na sala de aula, nem assim, é possível ter domínio total sobre como as palavras são interpretadas do outro lado da ponte. Como criar territórios comuns às palavras numa sala de aula? As palavras da professora e as palavras de Gabriel habitam o mesmo território? Como usar as palavras de modo que elas mediatizem a comunicação numa aula de ciências para crianças? Sob quais pontos de vista podemos analisar o modo de mediação adotado pela professora e relacioná-lo à enunciação da criança? Quais elementos dessa mediação discursiva podem ser relacionados às necessidades e ao motivo docente? E quais elementos podem sinalizar como indícios de desenvolvimento profissional docente?

Com esse pequeno episódio e com as tantas questões levantadas, queremos tão somente nos aproximar do foco deste estudo, o qual pressupõe a mediação discursiva docente em sala de aula como um espaço de relações semióticas fecundo à aprendizagem e ao desenvolvimento profissional docente. Nesse contexto, tomamos como problema de pesquisa, a seguinte questão: o que a mediação discursiva docente pode mostrar sobre o trabalho 
docente e desenvolvimento profissional de professores dos anos iniciais que ensinam ciências sob orientação investigativa?

Para tanto, delimitamos importantes escolhas: a sala de aula foi eleita como o lugar característico onde o ensino e a aprendizagem, de fato, se articulam e se realizam, e, de modo subsequente, como o lugar da apropriação de significados pelos sujeitos em inter-relação, professor e alunos; o professor foi tomado como um sujeito em processo de aprendizagem e desenvolvimento profissional, como tal, o sujeito a ser estudado; assim, a sala de aula, no contexto do trabalho e da aprendizagem docente, pode ser entendida como o lugar, por excelência, de mediação sobre o seu objeto de trabalho; o lugar de onde provêm e onde se expressam as necessidades, motivos e sentidos docentes, os quais são aqui relacionados à aprendizagem e desenvolvimento profissional; e, por fim, designamos a linguagem e, sobretudo, a palavra como o instrumento/signo mais importante na mediação docente das relações que permeiam o processo de ensino e aprendizagem.

As discussões tecidas no corpo desta tese são ancoradas na teoria histórico-cultural, cuja base epistemológica é o materialismo histórico e dialético. Karl Marx, Vigotski, Leontiev, Luria e Bakhtin, expoentes dessa matriz teórica, nos emprestam importantes elementos, entre eles, os significados de trabalho humano, atividade, mediação e linguagem, os quais nos possibilitam discutir o desenvolvimento profissional docente como um processo decorrente do trabalho docente.

Para Karl Marx, o trabalho, categoria fundante do materialismo histórico e dialético, consiste na relação mediada entre o homem e a natureza. É pelo trabalho, como atividade humana adequada a um fim, que o homem, ao mesmo tempo em que transforma a natureza para satisfazer as suas necessidades materiais e psicológicas, se autotransforma, desenvolvendo faculdades especificamente humanas. O desenvolvimento humano resulta-se da atividade do trabalho, o que confere a essa categoria a dimensão transformadora e criadora.

O conceito de atividade é fundamentado na obra de Vigotski, como elemento essencial na formação da consciência e, como princípio fundante, inspira Leontiev na elaboração da Teoria da Atividade. Na abrangência dessa teoria, o desenvolvimento do psiquismo, bem como da formação da consciência e da personalidade estão relacionados à "atividade principal", aquela que, construída nas condições concretas da vida, governa as principais mudanças nos processos psíquicos. 
Para Leontiev, cada atividade é mobilizada por um objetivo/motivo específico, se diferenciando de outra atividade, sobretudo por esses elementos. Em uma atividade, objetivo e motivo são coincidentes ou correspondentes, o que significa dizer que um sujeito se coloca em atividade quando o seu objetivo, aquilo para o qual suas ações se dirigem, corresponde ao motivo que o impele a realizar tal atividade.

O conceito de atividade, em completa relação com o conceito de trabalho, corresponde aos processos que “(...) realizando as relações do homem com o mundo, satisfazem a uma necessidade especial correspondente a ele" (Leontiev, 1978, p.68). Atividade é o trabalho tomado como práxis humana, cuja substância básica é a inseparabilidade entre a atividade teórica e a atividade prática. Essa inseparabilidade se traduz em práxis, na medida em que a prática se torna fundamento da teoria, e a teoria se desprende do seu estado puramente teórico e se insere na atividade reflexiva (Sánchez Vázquez, 2007).

Buscamos nos aportes dessa base teórica, sobretudo na Teoria da Atividade de Leontiev e na teoria vigotskiana sobre desenvolvimento e aprendizagem, elementos que nos ajudem a estabelecer relações entre a aprendizagem docente, desenvolvimento profissional e trabalho docente, sendo este último visto em sua dimensão transformadora, como produto de construções humanas, ou seja, como atividade ou práxis humana. Sob tal dimensão, o trabalho docente pode ser considerado como a atividade dominante do sujeito professor em seu estágio de vida como adulto, da qual desencadeia o seu processo de desenvolvimento profissional na abrangência dos diferentes nexos que se interligam para compor o significado de desenvolvimento profissional: formação do pensamento teórico, identidade, consciência, personalidade laboral, entre outros.

Em contraponto, discutimos o caráter alienante do trabalho docente, em que o professor, uma vez destituído do conhecimento, da possibilidade de planejamento e reflexão, não mais encontra em sua atividade laboral sentido para a sua autotransformação. Nesse caso, o motivo que o impele a trabalhar não mais coincide com o objetivo dessa atividade. Em outras palavras: o sentido pessoal que o professor atribui à sua atividade não mais corresponde à significação social ou função social da docência.

Esse quadro de alienação do trabalho docente manifesta em sua aparência a ideia de paralisação das ações humanas determinada por condições objetivas e subjetivas que impactam a profissão docente. Felizmente, a essência desse fenômeno mostra o caráter de mutabilidade da consciência e personalidade humana, a qual delega transitoriedade e continuidade ao processo de construção de sentidos. Novos motivos surgem das relações de 
trabalho, os quais impulsionam à busca de possibilidades encontradas nos núcleos de resistência subsistentes no próprio espaço dialético da alienação: o que à primeira vista se aparenta como caos, tem em si engendrado a sua própria contradição e negação. Professores, uma vez conscientes de sua condição de trabalhadores explorados, das circunstâncias históricas, politicas e econômicas nas quais eles estão inseridos, e dos elementos que os alienam ou os separam do trabalho como atividade humana e criadora, podem se constituir em coletivo e passarem a forjar espaços de atuação e superação e a negar o conteúdo alienante de seu trabalho. São, exatamente, esses elementos de contradição e de negação que podem se converter em motivos que promovem à construção de novos sentidos, por sua vez, capazes de conduzi-los a novas ações e à mudança de realidade.

Isso posto, inserimos a discussão sobre desenvolvimento profissional docente no âmbito do trabalho docente, na abrangência da atuação em sala de aula e nos espaços coletivos de atuação e de formação forjados no cotidiano da escola, os quais passam a ser considerados como núcleos de resistência ao conteúdo alienante do trabalho docente e, consequentemente, como núcleos articuladores de ações favoráveis à construção de novos sentidos com conteúdos que venham a superar o caráter de alienação, com reflexos sobre a consciência individual e coletiva. Essa inserção nos leva a ampliar o conceito de desenvolvimento profissional e a entendê-lo como um processo que implica na construção de sentidos favoráveis à construção da atividade laboral como práxis.

Considerar a práxis como um processo em construção guarda a ressalva de que não pressupomos o limiar ótimo de atividade humana, embora o vislumbremos, isto é, não se espera que o professor tenha atingido o nível máximo de consciência em relação aos sentidos que atribui à sua atividade pedagógica para que o consideremos em desenvolvimento humano. O sujeito situado em desenvolvimento profissional é o professor inserido no campo contraditório das ações diárias circunscritas à sua atividade, porém com determinado grau de consciência em relação às suas necessidades e inconclusões, como tal com motivos e sentidos que lhe impelem à busca de superações.

Portanto, motivo e sentido se constituem como conceitos chave no corpo desta tese, compreendidos e adotados na amplitude da Teoria da Atividade, por conseguinte, na relação dialética entre atividade humana e a formação da consciência. A construção de sentidos, desencadeada pela realização de motivos, consiste em mudanças no nível da consciência do sujeito - premissa fundamental para as relações que estabelecemos entre o modo geral de atuação docente e o desenvolvimento profissional. 
Com tais conceitos em mente e com a perspectiva de articula-los à discussão sobre mediação e linguagem, enriquecida por elementos teóricos, como enunciação e dialogia, adentramos à sala de aula e passamos a abordar o movimento dialógico discursivo estabelecido entre o professor e seus alunos como um processo eminentemente social, como tal, repletos de relações mediadas.

A atividade docente, como toda atividade laboral, é mediada por signos, instrumentos e pelo "outro". Não perdemos de vista a ideia de que "o outro" também "medeia as relações com o mundo, com as outras pessoas e com nós mesmos" (Braga, 2010, p. 23). O professor, como usuário da linguagem, e como mediador, lança mãos de variados recursos para conduzir sua aula a fim de criar oportunidades para que seus alunos se apropriem dos significados produzidos culturalmente e historicamente pela humanidade.

Ação e linguagem docente se integram para compor a mediação discursiva do professor, a qual se realiza nas relações mediadas advindas das enunciações ou atos de falas surgidas da própria necessidade de comunicação, característica do processo de ensino e aprendizagem. Segundo Bakhtin (2010), uma enunciação encontra voz em outra enunciação, compondo, desse modo, a dialogia, em que diferentes vozes são ouvidas e consideradas. A voz do professor só pode ser compreendida em relação às vozes dos alunos e vice versa.

Apoiados no materialismo dialético, tomamos a mediação discursiva docente como um conceito de destaque no corpo de nossas análises por integrar a ação docente e a linguagem, compondo e representando os processos dialógicos mediados semioticamente por signos e instrumentos. Como tal, a mediação discursiva docente passa a ser concebida como a unidade de análise das relações entre ensino e aprendizagem e, por suposto, das relações aqui estabelecidas entre trabalho docente, aprendizagem e desenvolvimento profissional docente. Como unidade, a mediação discursiva encerra-se como ação mediada, e como tal, contempla de modo irredutível e indecomponível, a atuação docente e a linguagem, como componentes que guardam elementos da totalidade das relações entre esses processos (Vigotski, 2010).

Escolhemos uma professora participante do coletivo da escola, como sujeito da pesquisa, cujo desenvolvimento profissional torna-se o foco em investigação. Os dados, empíricos, extraídos de aulas videogravadas e organizados em episódios de ensino, foram analisados de modo aproximado com a perspectiva microgenética. Centramos nossa atenção para detalhes manifestados via mediação discursiva docente em sua inter-relação dialógica com as enunciações dos alunos. Portanto, sua sala de aula, ou melhor, o movimento dialógico discursivo estabelecido por ela e seus alunos perfaz o eixo central de análise. 
Com base em Engestron (1999) e Daniels (2003), assentamos esse movimento dialógico discursivo, bem como a discussão sobre o desenvolvimento profissional docente, em um sistema coletivo de atividade. A sala de aula ganha a dimensão de uma comunidade multivocal composta por vozes para além daquelas que se fazem fisicamente presente, pois, ao analisarmos o movimento dialógico discursivo estabelecido entre a professora e seus alunos, nos atentamos para as vozes virtuais trazidas em sua memória de outras comunidades vocais, entre elas, a sua experiência formativa e profissional.

Em suma, a tese foi estruturada em seis capítulos. Os dois primeiros contemplam o arcabouço teórico: no primeiro, nos ocupamos da conceituação de trabalho como categoria fundante do materialismo histórico e dialético, bem como de elementos teóricos como motivo/objetivo, sentido/significado constituintes do conceito de atividade, tal qual fundamenta Leontiev. O contraponto a essa discussão é feito a partir do conceito de alienação e de trabalho alienado, bem como de suas implicações para a formação humana do trabalhador. Ainda nesse capítulo inserimos o trabalho docente e o desenvolvimento profissional docente no espaço dialético constituído entre a concepção de trabalho como atividade humana e de trabalho alienado, com a intenção de compreender possibilidades e entraves ao desenvolvimento profissional docente, criados no âmbito dessa relação dialética.

No segundo capítulo, configuramos, em nível teórico, a atuação docente mediada por ações e pela linguagem, retomando conceitos como mediação, dialogia e enunciação. Aproximamo-nos da atividade docente em ensino de ciências, ao apresentarmos elementos contemplados por variadas pesquisas em âmbito nacional e internacional em relação a contextos linguísticos de sala de aula, e aos diferentes modos de atuação docente, nos quais buscamos subsídios para discussões tecidas neste trabalho sobre formação e desenvolvimento profissional docente.

No terceiro capítulo, retomamos o contexto da pesquisa, fornecendo elementos importantes para a compreensão do leitor sobre seus objetivos e o problema que a orienta. Posteriormente, discutimos sobre a abordagem metodológica adotada, nos filiando ao método construído por Vigotski a partir de pressupostos oriundos do materialismo histórico e dialético.

No quarto capítulo, a partir da orientação metodológica pressuposta no capítulo precedente, apresentamos o procedimento de análise, o qual contém os eixos essenciais norteadores da configuração da mediação discursiva docente, como o padrão de diálogo e 
padrão temático. Apresenta também as categorias orientadoras da análise, como os motivos e sentidos docentes, por meio das quais discutimos as necessidades formativas e os indícios de desenvolvimento profissional. Ainda nesse capítulo, apresentamos a narrativa com a história da vida formativa e profissional da professora escolhida como sujeito da pesquisa, considerada como importante comunidade vocal do sistema coletivo de atividade.

A análise toma corpo no quinto capítulo mediante a configuração das mediações discursivas docentes de três aulas, estruturadas em episódios de ensino, cujos dados são interrelacionados com episódios de formação e citações extraídas de entrevistas e depoimentos proferidos em encontros formativos. A partir do conhecimento sobre a essência das mediações discursivas, compusemos o modo geral de ação docente e o tomamos como base para estabelecer as possíveis relações com a aprendizagem e desenvolvimento profissional.

O trabalho é finalizado com a apresentação das conclusões sobre as relações construídas e discutidas no processo de análise acerca da aprendizagem e desenvolvimento profissional da professora investigada e com considerações que abordam os objetivos mais amplos da pesquisa referentes às suas contribuições para o aprofundamento acerca da formação contínua de professores. 


\section{Capítulo I: Atividade humana, trabalho docente e desenvolvimento profissional}

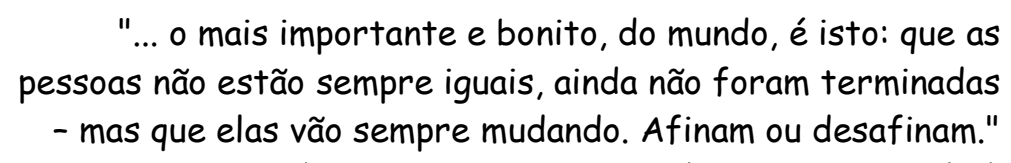

(Guimarães Rosa - Grande Sertão: Veredas)

Ao longo deste capítulo, estabelecemos relações entre atividade humana, trabalho docente e desenvolvimento profissional docente a partir de conceitos como trabalho humano, atividade, mediação e alienação, originários do materialismo histórico e dialético, base epistemológica da teoria histórico-cultural. Karl Marx, Vigotski, Leontiev e Luria, expoentes dessa matriz teórica, nos emprestam importantes elementos que nos possibilitam tecer tais relações à luz da própria formação histórica e cultural do ser humano, no seu processo de humanização.

A partir dessas relações buscamos subsídios para nos aproximarmos do trabalho docente a fim de evidenciar a sua dimensão humana transformadora em contraponto com a sua dimensão não transformadora, em que o professor é separado, isto é, alienado do conhecimento - seu principal instrumento de trabalho. Quais relações podem ser estabelecidas entre o trabalho formador e criador e o trabalho docente? Quais elementos influenciam e compõem o desenvolvimento profissional? Em que situação o trabalho docente se configura como trabalho alienado ou se constata a não correspondência entre a significação social da atividade docente e o sentido dessa atividade para o professor? Este é o conteúdo do primeiro capítulo.

\subsection{Trabalho e atividade humana - categoria fundante do materialismo histórico- dialético}

O trabalho é uma atividade especificamente humana. Karl Marx, ao proferir tal afirmativa no livro I do $O$ Capital, o diz com a convicção de que é pelo trabalho que nos fazemos humano. Leontiev (1978, p. 267) em acordo com Marx reafirma tal pressuposto, ao dizer que nós não nascemos humanos, nos tornamos humanos "no decurso da vida, por um 
processo de apropriação da cultura criada pelas gerações precedentes", isto é, "no decurso do desenvolvimento histórico da sociedade humana". Integrar-se num grupo que "lhe ensine a cultura e preencha a distância entre o cérebro e o ambiente" é condição para que o indivíduo da espécie humana se torne homem (Nóvoa, 1991, p. 109).

O desenvolvimento do ser humano não depende apenas de suas características biológicas, mas também da relação que se estabelece com o mundo, de sua apropriação da cultura produzida e acumulada historicamente. Somos seres eminentemente sociais, formados e transformados na atividade humana, isto é, na relação com o outro e com os instrumentos mediadores dessa relação. A educação exerce papel fundamental nesse processo, pois lhe é cabido a criação de atividades educativas capazes de mediar as relações do educando com o mundo e de mediatizar a apropriação dessa produção social.

Qualquer indivíduo criado separado das relações com a sociedade se alija do processo de desenvolvimento da humanidade e não adquire características humanas, como linguagem, pensamento e muitos movimentos corporais. Um bom exemplo é retratado no filme “O enigma de Kaspar Hauser”, dirigido por Werner Herzog em 1974. Hauser, criado aprisionado em cativeiro até os 18 anos de idade, destituído do contato verbal com pessoas e sem poder se movimentar, não sabia falar e nem sequer ficava equilibrado de pé. Apenas depois, incluído à sociedade, pôde, paulatinamente, aprender a falar e adquirir as habilidades motoras humanas.

Outro exemplo ilustrativo que pode nos levar a refletir sobre a importância das relações humanas e da transmissão das aquisições culturais de geração a geração na formação do indivíduo e do próprio movimento histórico, é trazido por Leontiev (1978), em seu livro “O desenvolvimento do Psiquismo". Esse autor cita a obra de Piéron (1959), a qual retrata essa ideia nos levando a uma instigante imaginação: o planeta Terra teria sido acometido por uma catástrofe com a sobrevivência de apenas crianças pequenas. A morte de todos os adultos, não significaria o fim do gênero humano, mas o processo histórico seria “inevitavelmente” interrompido. Não restaria ninguém para ensinar as crianças a falar, a ler, a usar a produção deixada pelas gerações anteriores. "A história da humanidade teria que recomeçar” (Leontiev, 1978, p. 272). Ou seja, necessidades, até então superadas, teriam que ser recriadas ou reinventadas. 
Exemplos como esses nos põe em frente à história da humanidade, cuja sistematização constitui a essência do materialismo histórico e dialético, no qual o trabalho é eleito como categoria fundante.

O trabalho se estabelece como o próprio intercâmbio entre o homem e a natureza, o qual se constitui essencialmente como atividade mediada. $\mathrm{O}$ conceito de mediação permeia a concepção marxista e, sobretudo, a obra de Vigotski, como a chave da relação homem/natureza, em que, a ação humana não se estabelece de forma direta e imediata, mas interposta por instrumentos e ferramentas psicológicas. A atividade mediada guarda a relação estabelecida entre o sujeito, o seu objeto de trabalho, interposta por instrumentos e signos, e os resultados decorrentes dessa atuação, nos quais se tem objetivado a essência humana e material presentes na relação.

O instrumento ou "objecto material", mediador das relações de produção humana inerentes ao trabalho, atua como um prolongamento da mão e da ação humana, "capaz de objectivar ou modelar determinadas funções do organismo humano" (Leontiev, S/D, p. 151). Para esclarecer a definição de instrumento, Leontiev nos lembra do machado de pedra, um simples objeto material usado por nossos antepassados, o qual consistia em uma pedra toscamente talhada dos dois lados, com uma ponta cortante em um dos extremos e do outro uma fenda para manuseio. Esse instrumento usado para golpear, cortar e ferir assumia as "funções que realizavam os punhos, os dentes e as unhas". Atualmente poderíamos exemplificar essa relação de mediação e de objetivação, considerando a evolução histórica e cultural de uma infinidade de instrumentos mediadores, como por exemplo, esse computador por meio do qual as funções das mãos e da mente humana são objetivadas na produção de um texto, tal qual ocorre na realização deste trabalho.

Torna-se impossível falar do trabalho senão como uma atividade humana mediada, por meio da qual os homens, a um só tempo, transformam a natureza para satisfazer as suas necessidades materiais e psicológicas e se autotransformam, desenvolvendo faculdades especificamente humanas. Karl Marx (1985, p. 149) escreve:

Antes de tudo, o trabalho é um processo entre o homem e a Natureza, é um processo em que o homem, por sua própria ação, medeia, regula, e controla seu metabolismo com a Natureza. (...) Ele põe em movimento as forças naturais pertencentes à sua corporalidade, braços e pernas, cabeça e mão, a fim de apropriar-se da matéria natural numa forma útil para sua própria vida. Ao atuar, por meio desse movimento sobre a natureza externa a ele e ao modificá-la, ele modifica, ao mesmo tempo, sua própria natureza. 
Marx quer dizer que todo ato de trabalho começa com uma teleologia, com objetivos advindos de necessidades criadas. Deixa claro que só com a ideia, a necessidade que impele o ato de planejar não seria resolvida; nada seria produzido historicamente e objetivamente apenas com bons projetos. O processo de trabalho finaliza com a produção do instrumento e, por suposto, com a satisfação da necessidade.

$\mathrm{Na}$ totalidade do processo de realização do trabalho, corpo e mente humanos são postos em movimento. O produto do trabalho incorpora essa natureza humana, ou seja, as forças naturais do homem "pertencentes à sua corporalidade" são objetivadas e exteriorizadas no instrumento produzido. Essa objetivação é o processo pelo qual a totalidade dos instrumentos produzidos guarda em si a marca humana. $\mathrm{O}$ objeto resultante de uma atividade contém, a um só tempo, a objetivação imediata do trabalho de quem o produziu e a objetivação cumulativa das tantas gerações precedentes. Como afirma Sánches Vázquez (2007, p. 129), o homem “(...) é por excelência um ser que necessita objetivar-se de um modo prático, material, produzindo, assim, um mundo humano".

Esse mundo humano, do qual fala Sánchez Vásquez, é também produto da criação e imaginação humana. A necessidade, bem como o planejamento dos meios ou dos instrumentos destinados a satisfazê-la pode compor um processo de criação e imaginação de algo nunca existido. A imaginação, antes pertencente ao mundo interno da mente humana, adquire uma "concretude material", se cristaliza, se faz objeto e "começa a existir realmente" (Vigotski, 2009a, p. 29). Para Vigotski a imaginação é um atributo humano presente em toda atividade que "tem como resultado a criação de novas imagens ou ações" (idem, p. 13). "Todos os objetos da vida cotidiana, sem excluir os mais simples e comuns, são imaginação cristalizada" (Ribot ${ }^{2}$ apud Vigotski, 2009a, p. 15).

Como vimos, criar, imaginar, produzir e objetivar-se compõem o processo de produção do mundo humano. Vale ressaltar que em cada objeto se objetiva, e dele se exterioriza, não apenas as forças físicas do homem, mas a força interna de seus pensamentos, imaginações, valores culturais, habilidades e conhecimentos envolvidos na realização da atividade. Como afirma Leontiev (1978), o que se encarna e se objetiva no instrumento são os traços essenciais da atividade. Ou seja, todo instrumento não é senão "o produto da cultura material que leva em si, da maneira mais evidente e mais material, os traços característicos da criação humana" (idem, p. 268).

\footnotetext{
${ }^{2}$ RIBOT, Armanda Théodule. Essai sur l'imagination crêatice (Paris: Felix Alcan, p. 140).
} 
Ao longo da história da humanidade essa produção material e ininterrupta, garante a produção constante de conhecimentos, e é garantida pela criação de novas necessidades e possibilidades. Como já dissemos antes, a apropriação pelos sujeitos dos conhecimentos historicamente produzidos, acumulados e exteriorizados, melhor dito, da "experiência sóciohistórica da humanidade", é o processo que garante a "formação das faculdades especificamente humanas" (Leontiev, 1978, p. 268), as quais se consubstanciam na completude do desenvolvimento tanto do individuo como da humanidade.

Marx não se refere ao trabalho como uma forma instintiva, animal, e sim, ao trabalho numa forma em que pertence exclusivamente ao ser humano. Trabalho é uma atividade propriamente humana, a qual "implica a intervenção da consciência, graças à qual o resultado existe duas vezes - e em tempos distintos: como resultado ideal e como produto real" (Sánchez Vázquez, 2007, p. 221). Ou seja, apenas o homem, planeja, prevê, impõe ao trabalho a atividade teórica e a atividade prática.

A esse respeito, vale lembrar a célebre comparação feita por Marx (1985) entre as operações das abelhas na construção dos favos de sua colmeia e o trabalho do arquiteto: o pior arquiteto se distingue da melhor abelha por ele antecipar a sua construção em mente, em plano de trabalho, antes de torná-la realidade. Nenhum animal realiza trabalho, por mais complexa que seja a sua atividade e por melhor que seja o resultado de suas operações, todas elas, sem exceção, são operações biológicas e instintivas, em respostas a necessidades relacionadas à alimentação e à sua adaptação ao meio.

Apenas o homem tem a sua atividade orientada a um fim, tem a sua relação com a natureza mediada por instrumentos. Apenas o homem cria necessidades e os meios para satisfazê-las. Os animais tecem teias, constroem ninhos, vivem em conjunto, usam instrumentos para aproximar o alimento de si, o que são, sem dúvida, atividades complexas, porém nenhuma delas modifica a natureza, acumula cultura, transforma instrumentos. Como bem lembrou Duarte (2004) o pássaro joão-de-barro constrói seu ninho há milhares de anos exatamente como o faz hoje. O ninho do joão-de-barro não foi transformado no decorrer dos tempos, pois consiste num ato instintivo, não havendo, de modo algum, produção de conhecimentos e acúmulo cultural.

Outro aspecto inerente ao ser humano são as ações coletivas na realização de atividades. O trabalho é um processo não apenas mediado por instrumentos, mas também pelas relações humanas em sociedade. Parafraseando mais uma vez Karl Marx, destacamos que qualquer produção humana ocorre por meio de colaborações e trocas entre seus 
participantes. "Para produzir, entram em ligações e relações determinadas uns com os outros e não é senão nos limites destas relações e destas ligações sociais que se estabelece a sua relação sobre a natureza, a produção" (Karl Marx³ apud Leontiev, 1978, p. 75)

Nesse sentido, vale a pena lembrar o que nos disse Werstch (1999) sobre a sociabilidade da ação humana. Segundo esse autor, mesmo uma ação contemplativa é situada socialmente e culturalmente, pois nossas percepções, sensações e pensamentos são mediados pelo outro, por recordações e por conhecimentos apropriados em experiências vividas até então.

A palavra e a linguagem também são imanentes à atividade humana. Para Leontiev (1978), palavra e linguagem se formam no trabalho, num processo em que homens entram forçosamente em relação uns com outros, criando a necessidade premente de comunicação. Em nenhuma situação, a linguagem se destaca da produção material e do processo de educação, se constituindo não somente como um meio de comunicação, mas como uma forma de consciência e pensamento humano.

O papel mediador da linguagem também se estabelece no exercício do registro da memória humana. Por sinal, enfatizamos que memória e registro são elementos absolutamente humanos, de importância imensurável para o desenvolvimento da humanidade, pois não é possível imaginar a história humana sem registros, sejam desenhos rupestres, sejam livros e outras formas atuais. Um e outro materializam o pensamento humano de sua época e garantem o conhecimento sobre o passado em tempo presente.

A consciência humana se forma junto com a transformação do homem no processo histórico, em que o trabalho ou a atividade se constitui com modo central de mediação. Como individuo, não nascemos com consciência do mundo, nos apropriamos do mundo na medida em que estabelecemos relações sociais e entramos em atividade. Na teoria histórico-cultural o conceito de atividade ocupa posição especial, se constituindo como a base ou substância da consciência e do desenvolvimento do psiquismo. Portanto, consideramos importante levantarmos algumas considerações sobre a Teoria da Atividade sistematizada por Leontiev, o que poderá nos municiar de mais elementos para prosseguirmos em nossas construções teóricas.

\footnotetext{
${ }^{3}$ A Nova Gazeta Renana, t. III. Ed. Sociales, (S/D) p. 237.
} 


\subsection{Sobre a Teoria da Atividade}

O conceito atividade origina-se do materialismo histórico e dialético, introduzido por Marx na teoria do conhecimento com um rigoroso sentido materialista, traduzido no entendimento da prática humana

(...) como a base do conhecimento humano, como o processo em cujo curso surgem as tarefas cognoscitivas, se engendram e desenrolam a percepção e o pensamento do homem (...); na prática, disse Marx, o homem deve demonstrar a verdade, a realidade e o poderio, o caráter multifacetado de seu pensamento (Leontiev, 1983, p. 15).

Para que essas teses de Marx não sejam interpretadas como expressões do pragmatismo, Leontiev (1983, p. 15) esclarece que não se trata de identificar a teoria como prática, mas de reafirmar que "o conhecimento não existe fora de um processo vital, que por sua própria natureza, é um processo material e prático”.

Segundo Leontiev (1983) quem introduziu a categoria atividade como método de análise na psicologia foi Vigotski, com ênfase para o papel da atividade humana como mediadora do desenvolvimento geral humano. Com foco sobre o desenvolvimento psíquico e formação da consciência, Vigotski privilegia a mediação como elo fundamental nesses processos, com destaque para os conceitos de instrumento, signo e objetivo e introduz o conceito de motivo, ao se referir à esfera motivacional da consciência. Leontiev, por sua vez, amplia e aprofunda esses conceitos para propor a estrutura geral da atividade humana em sua Teoria da Atividade.

A essência da Teoria da Atividade discorre sobre o desenvolvimento do psiquismo, vinculando-o à atividade principal ou dominante e não à atividade em geral. Caracteriza-se como principal ou dominante aquela atividade cujo "desenvolvimento governa as mudanças mais importantes nos processos psíquicos e nos traços psicológicos da personalidade da criança, em certo estágio de seu desenvolvimento" (Leontiev, 1991, p. 65).

Leontiev esclarece que o conteúdo de cada estágio de desenvolvimento não se relaciona à idade do indivíduo, mas às suas condições e modos de vida, os quais são determinados "pelas relações sociais existentes e pelo lugar que o indivíduo ocupa nestas relações" (idem, 1978, p. 89). Tais condições e modos de vida determinam qual atividade é a principal ou qual é a mais importante em determinado estágio de vida do sujeito. Essa atividade tem predomínio sobre outras, exatamente por circunscrever um círculo mais amplo 
de fenômenos e de relações humanas, nas quais o sujeito se envolve e participa. Além dessa importante característica, a atividade principal possui o atributo de desencadear outras formas de atividades correlacionadas.

Leontiev sugere a brincadeira ou o jogo como a atividade principal na infância; na fase pré-escolar, seria o estudo sistemático; e na adolescência e fase adulta, a atividade principal poderia ser o estudo ou o trabalho. Seja qual for a atividade que predomine em determinado estágio, é nela que os "processos psíquicos particulares tomam forma ou são reorganizados" (ibidem, 1991, p. 64).

Para supormos uma atividade como principal em determinado estágio de desenvolvimento, torna-se necessário conhecer as condições concretas de vida do sujeito. Para exemplificar, perguntamos: seria o estudo a atividade principal de crianças que se encontram no estágio escolar, todavia submetidas a condições e modos de vida desfavoráveis socialmente e/ou emocionalmente? Seria o estudo a atividade principal de crianças que, embora, não sejam submetidas a condições e modos de vida desfavoráveis socialmente, por motivos diversos, não centram sua atenção nas atividades escolares?

Questões como essas, além de nos levar a compreender melhor o conceito de atividade principal, podem nos fazer pensar sobre a profundidade das relações de ensino e aprendizagem que permeiam os conteúdos dos estágios de desenvolvimento. Indagamos ainda: sob qual dimensão o conceito de atividade poderia ser apropriado pelo ensino para se pensar sobre a aprendizagem? Qual é o sentido atribuído ao conceito de atividade em tal dimensão teórica e prática?

A precisão sobre esse conceito está na base da Teoria da Atividade. Como afirma Leontiev (1991, p. 68)

Não chamamos todos os processos de atividade. Por esse termo designamos apenas aqueles processos que, realizando as relações do homem com o mundo, satisfazem uma necessidade especial correspondente a ele.

Por atividade, designamos os processos psicologicamente caracterizados por aquilo a que o processo, como um todo, se dirige, coincidindo sempre com o objetivo que estimula o sujeito a executar esta atividade, isto é o motivo (1991, p.68).

Para Leontiev (1991) atividade é o reflexo da relação dos sujeitos entre si e destes com o mundo que os cerca. Toda atividade origina-se de uma necessidade, por sua vez, materializada no motivo, o qual impele o sujeito a buscar meios para satisfazer a necessidade 
e atingir o objetivo. O motivo, completamente relacionado às condições concretas de vida do sujeito, abrange conteúdos de cunho social, material, cognitivo e emocional. Para Leontiev, o motivo tem um valor substancial, pois consiste na gênese da atividade, desenvolvendo um papel fundamental em sua estrutura. O próprio Leontiev (1983, p. 83) diz que "o objeto da atividade é o seu motivo real".

Cada atividade é mobilizada por um objetivo/motivo específico, se diferenciando de outra atividade, sobretudo por esses elementos. Em uma atividade, objetivo e motivo são coincidentes ou correspondentes, o que significa dizer que um sujeito está em atividade quando o motivo que o impele coincide com o objetivo, com aquilo para o qual as suas ações se dirigem. Ou seja, para afirmar que uma pessoa está ou não em atividade é preciso analisar o caráter psicológico do processo; é preciso ter conhecimento sobre qual motivo a coloca em ação.

Leontiev explica esse processo com o seguinte exemplo: um estudante, lendo um livro para prestar um exame, foi informado de que a leitura desse livro não mais seria necessária para a realização da prova. Com tal informação, que atitude tomará esse estudante? Colocará o livro de lado, imediatamente? Continuará a leitura? Ou, com pesar, desistirá de ler o livro? A atitude tomada pelo estudante mostrará o seu motivo.

O abandono imediato do livro indicaria que o motivo do estudante não era o conteúdo do livro, mas apenas a sua aprovação no exame. Por conseguinte, a atividade não era a leitura do livro, mas sim a preparação para o exame. O seu motivo, ser aprovado no exame, coincidia com o objetivo de se preparar para o exame. Portanto, a leitura se configurava apenas como uma ação no corpo da atividade de preparação para o exame.

Em caso de continuar a leitura ou de abandoná-la com pesar, o estudante teria mostrado que o seu processo de leitura estava sendo estimulado pelo conteúdo do livro, sendo este, portanto o seu motivo. Nesse caso, a leitura se constituiria como a atividade, pois o motivo do estudante - o conteúdo do livro - o induzia a ler para satisfazer a necessidade de conhecer e aprender o assunto tratado no livro.

O exemplo acima nos leva a prestar a atenção no motivo, como elemento importantíssimo na identificação de qual atividade o sujeito realiza. A coerência entre motivo/objetivo também se destaca no exemplo da leitura como atividade: se o motivo é o conteúdo do livro, portanto o objetivo coincidente é conhecer e aprender tal conteúdo.

Além da necessidade, motivo e objetivo, uma atividade estrutura-se em ações e operações. Desencadeada pelo motivo, objetivo e necessidade, a atividade é posta em movimento 
por um conjunto de ações relacionadas entre si, orientadas e estimuladas pelo objetivo geral da atividade. A ação é compreendida como "um processo cujo motivo não coincide com o seu objetivo (isto é, com aquilo para o qual ele se dirige), mas reside na atividade [objetivo da atividade] da qual ela faz parte" (Leontiev, 1991, p. 69).

Há relativa independência entre a ação e a atividade, ainda que a ação seja subordinada ao objetivo da atividade. Essa relação de independência explica o fato de uma mesma ação poder fazer parte de diferentes atividades. Por exemplo, a ação de leitura de um determinado livro pode fazer parte da atividade de preparação para um exame, como pode compor outra atividade de estudo ou de lazer.

Para melhor diferenciar uma ação de uma atividade, vamos exemplificar com uma professora, em atividade, ensinando ciências para crianças. Para admitirmos que ela realiza uma atividade, partimos do pressuposto de que conhecemos o motivo que a induz a trabalhar - criar e desenvolver oportunidades de aprendizagem para seus alunos, sendo este motivo coincidente com o objetivo da atividade de ensinar, que seria a própria aprendizagem dos seus alunos em ciências. Então, proporcionar resoluções de problemas de cunho experimental, criar oportunidades de leituras ou garantir conversações entre seus alunos, são ações, cujos motivos criar oportunidades de aprendizagem - são direcionados para o cumprimento do objetivo da atividade de ensinar, da qual essas ações fazem parte.

Cada ação, por sua vez, tem o objeto em si, ou seja, tem um alvo reconhecido pelo sujeito. A ação de garantir conversações, por exemplo, encerra o objetivo imediato de fazer com que os alunos falem sobre o que aprenderam e/ou que façam perguntas sobre o assunto em pauta. Como é possível notar, o objetivo ou objeto dessa ação aparece para o sujeito em completa relação com o motivo da atividade. Fazer com que os alunos falem o que aprenderam tem certa relação com o motivo/objetivo da atividade de ensinar, qual seja, proporcionar a aprendizagem. Desse modo, podemos reafirmar que ensinar se constitui como uma atividade para essa professora.

De fato, a relação que há entre a atividade e a ação não é de fácil entendimento à primeira vista, uma vez que no processo de realização de uma ação esta pode ser transformada em uma atividade. A conversão da ação em atividade está diretamente vinculada à transformação na qualidade dos motivos que envolvem o sujeito. Para Leontiev, os motivos podem aparecer para o sujeito como "motivos compreensíveis" ou "como motivos eficazes". A ação se torna uma atividade para o sujeito quando o motivo, antes compreensível, se transforma em motivo eficaz. 
Como o próprio nome sugere, motivo eficaz é aquele que de fato conduz o sujeito para o objetivo da atividade; motivo compreensível é aquele que não coincide com o objeto da atividade.

Vamos usar um exemplo hipotético para explicar a conversão de uma ação em atividade. Suponhamos que há uma professora de ciências que, embora reconheça que a atividade educativa tenha como significado ou objetivo social a aprendizagem dos alunos, o motivo que dirige suas ações é apenas a sua subsistência humana, ou seja, ganhar o seu salário. Esse motivo não corresponde com o objetivo da atividade educativa, caracterizando-se, portanto, como um motivo compreensível. Ensinar para essa professora, portanto, não consiste em uma atividade, mas apenas em uma ação.

Vamos imaginar que nossa professora remova-se para outra escola, onde é convidada a participar de um processo formativo, o qual privilegia o trabalho coletivo com o intuito de se pensar estratégias de ensino para ensinar de modo a melhorar a aprendizagem dos alunos. Por um longo período, essa professora participou dos encontros formativos, realizou parcialmente as estratégias de ensino, sem, no entanto se envolver completamente. O motivo de suas ações ainda não correspondia com o objetivo da atividade da docência.

Com a continuidade dos estudos coletivos e dos planejamentos e realizações das novas estratégias de ensino, esse quadro foi se modificando na consciência de nossa professora. As boas parcerias estabelecidas com suas colegas de trabalho, a alegria com que seus alunos passaram a se envolver e a participar das aulas, bem como os novos resultados satisfatórios no quadro da aprendizagem dos alunos, aceleram o processo de transformação em seus motivos: o motivo compreensível vai se tornando motivo eficaz. O motivo - levar seus alunos a aprender começa a ser percebido e a fazer sentido para a professora, ou seja, vai ganhando existência em sua consciência. Ela começa a notar que sua ação de ensinar não apenas garante o seu salário, mas também bons resultados junto aos seus alunos, sem falar no clima de confiança e solidariedade que foi se estabelecendo junto às suas parceiras de trabalho. Criar oportunidades de aprendizagem para seus alunos passou a ser o motivo que lhe impele a trabalhar, considerado como eficaz por coincidir com o objetivo da atividade educativa, qual seja, proporcionar a aprendizagem. O motivo, antes compreensível, tornou-se motivo eficaz.

O processo vivenciado por tal professora não foi senão o surgimento de uma nova atividade: a ação de ensinar tornou-se atividade de ensinar. Para a professora, ocorreu uma "nova objetivação de suas necessidades" (Leontiev, 1991, p. 71), o que significa dizer que essas necessidades passaram para um nível mais alto de compreensão. O seu estágio de 
desenvolvimento profissional foi influenciado por novas relações sociais, consequentemente, passou a apresentar novos conteúdos, os quais modelaram a nova atividade e alteraram o conteúdo do sentido atribuído pela professora à atividade educativa. Isto é, o conteúdo de sua consciência em relação à sua atividade laboral foi alterado. Como vimos, a gênese dessa alteração reside na mudança de qualidade do motivo - de compreensível para eficaz. Ainda que o exemplo em discussão seja hipotético, ele nos permite sugerir a potencialidade dos motivos eficazes na alteração e/ou construção de sentidos com novos conteúdos.

Vamos continuar tomando como exemplo a atividade de ensinar realizada pela professora para diferenciarmos ações de operações. Ações e operações se distinguem tanto em suas origens, como em suas dinâmicas e funções. A operação é o modo como se executa determinada ação. Uma mesma ação pode ser executada por diferenciadas operações.

Vamos supor que nossa professora na abrangência de sua atividade decida propor a resolução de um problema para ensinar determinado conhecimento cientifico, o que lhe exigiu a realização da ação de mediar o processo de resolução do problema por meio de uma situação experimental. Uma vez em sala de aula, realiza a sua ação mediante a execução de operações diversas: sugerir o problema a ser resolvido; organizar os alunos em grupo; orientar os grupos de trabalho; verificar o uso dos materiais disponíveis; dirigir a sua atenção para o modo como os alunos estão empregando os materiais e constituindo os seus modos de ação; delimitar e controlar o tempo da aula, etc. Outra professora poderia realizar a mesma ação com a execução de outras operações, a depender das condições materiais de trabalho e de seus objetivos, por exemplo. Diferentes fatores determinam o modo de ação e o respectivo conjunto de operações de cada sujeito.

Outro aspecto a ressaltar é que determinado procedimento pode ser executado como ação por um sujeito e como operação para outro. Ainda mais, uma determinada ação pode ser operacionalizada ao ser desenvolvida pelo sujeito, de modo a ser transformada em uma operação. Imaginamos que a referida professora resolva introduzir em suas aulas o uso da lousa digital. Embora ela já tenha recebido treinamentos, ainda não domina completamente os novos recursos: arrastar figuras, recortar, colar, acessar a internet, abrir arquivos, gravar conteúdos e organizar trabalhos com apenas um toque dos dedos ou de uma caneta especial são procedimentos que requerem, em tal momento do estágio de desenvolvimento da professora, atenção para serem realizados. Falamos, então, que esses procedimentos se constituem como um conjunto de ações realizadas separadas uma das outras. Em um futuro muito breve, a professora dominará o uso da lousa digital, de modo que essas ações tomarão a forma de operações, pois passarão a ser 
realizadas automaticamente. As ações, antes realizadas uma a uma, serão incorporadas à dinâmica geral da ação de ministrar àquela aula, de tal modo que a professora deslizará seus dedos ou a sua caneta sobre a tela virtual, sem sequer notar seus movimentos. Em tal estágio, as ações terão sido operacionalizadas pela professora, ou seja, terão se tornado operações.

Em suma, projetar imagens contidas em um site da internet e arrastar arquivos numa tela de uma lousa virtual, orientar grupos de alunos para a resolução de problemas, controlar o tempo de determinada aula, são exemplos de operações sem motivos aparentes, as quais compõem a ação de ensinar determinado conteúdo científico, por sua vez constituinte da atividade de ensinar ciências. Ensinar ciências para que seus alunos aprendam é uma das atividades decorrentes da docência, supostamente privilegiada como principal no estágio de desenvolvimento psíquico da referida professora.

Em síntese, a estrutura da atividade tal qual propõe Leontiev pressupõe a existência de uma necessidade, convertida em motivo, o qual impele o sujeito a realizar ações e operações direcionadas para o alcance de determinado objetivo.

Atualização da Teoria da Atividade - terceira geração

Estudos posteriores realizados por Engestrom (1999) e referenciados por Daniels (2003) discutem a Teoria da Atividade em três gerações. Para esses autores, a primeira geração, fundamentada por Leontiev, necessita ser ampliada, de modo que tal abordagem extrapole o limite das ações do indivíduo e alcance o nível de um sistema coletivo de atividade.

Engestrom (1999) considera a concepção vigotskiana sobre mediação como fundamento base para o desenvolvimento da Teoria da Atividade. Esse autor utiliza o triângulo básico explicativo da atividade mediada para representar a primeira geração da Teoria da Atividade.

Meios mediacionais (ferramentas) (máquinas, escritas, fala, gesto, arquitetura,

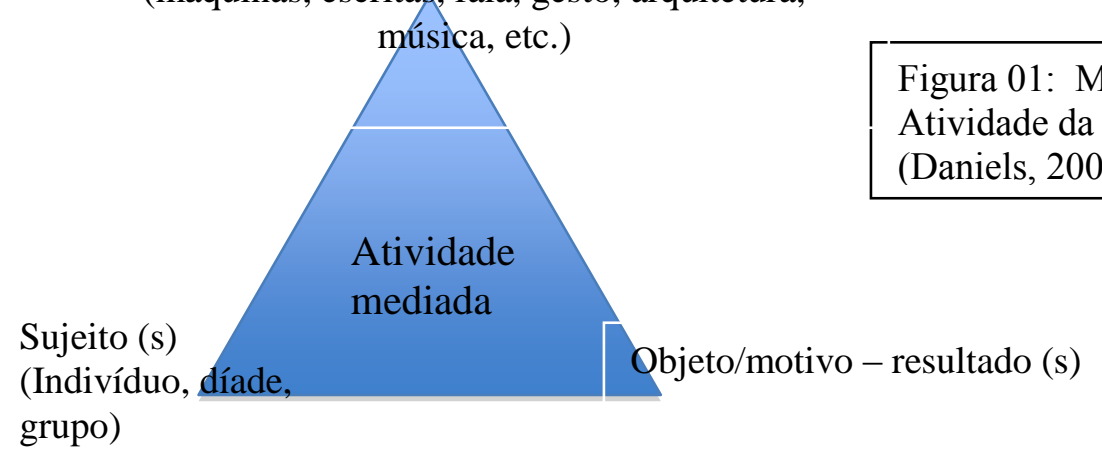


Nessa representação os sujeitos atuam por meio de signos e instrumentos para atingir o objetivo da atividade. Para Engestrom, é necessário que a atividade seja representada em um sistema, cujo modelo seja capaz de explicitar seus componentes e relações. Em suas palavras:

Estou convencido de que, a fim de transcender as oposições entre a atividade e o processo, atividade e ação, e da atividade e da comunicação, e para aproveitar ao máximo o conceito de atividade em pesquisa concreta, precisamos criar e testar modelos para explicar os componentes e relações internas de um sistema de atividade (Engestrom, 1999, p. 29-30).

Engestrom (1999, p. 31) mostra coerência com a essência do conceito de mediação, sem alterar ou se contrapor aos fundamentos da Teoria da Atividade.

(...) as questões centrais da teoria da atividade permanecem o objeto - que é o que liga minhas ações individuais para a atividade coletiva. No entanto, o resultado projetado já não é momentâneo e circunstancial, mas sim, consiste socialmente em importantes novos significados objetivados e em novos padrões de interação relativamente duradouros.

Verificamos tal coerência e ampliação na representação da terceira geração da Teoria da Atividade, a qual consiste no acréscimo de três triângulos à representação triangular construída a partir dos fundamentos de Vigotski. Vide representação a seguir:

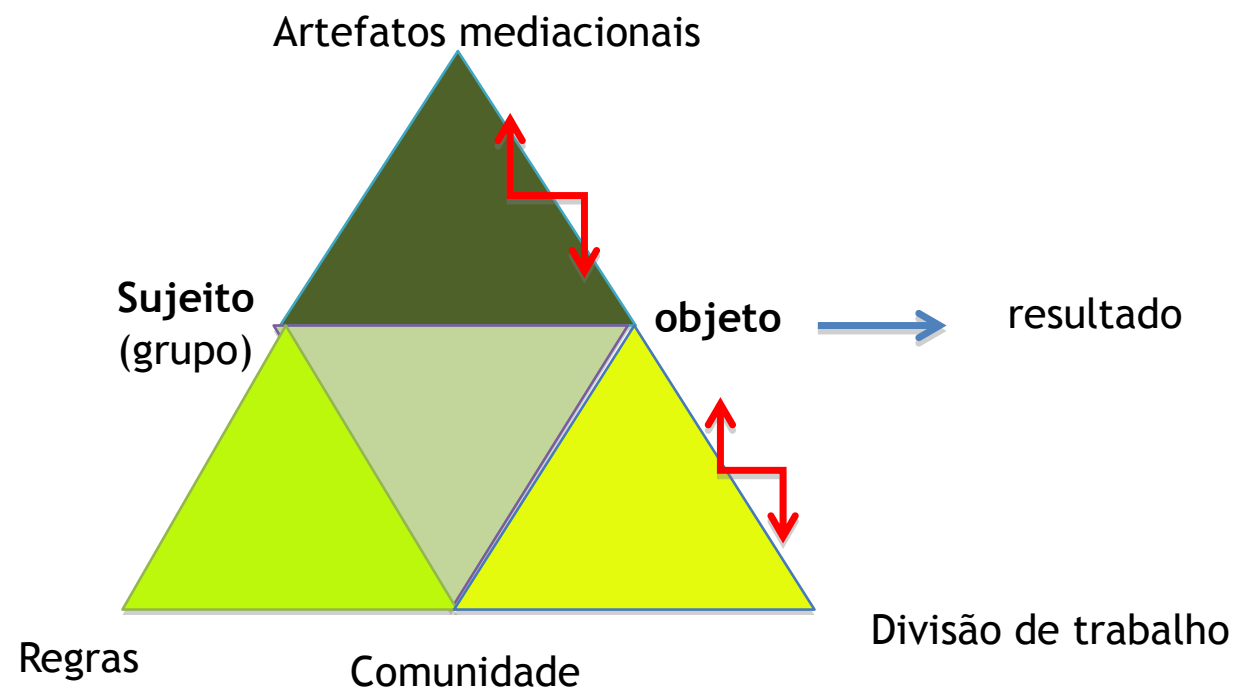

Figura 02: Sistema Coletivo de Atividade em Engestrom (1999) "terceira geração" da Teoria da Atividade. 
Ao ampliar a representação da atividade mediada, tal qual propunha Vigotski, Engestrom intenta possibilitar melhor visibilidade da totalidade dos sistemas de atividade em seu nível macro do coletivo e da comunidade, com ênfase na análise das interações sem, no entanto, perder de vista a atuação do(s) sujeito(s) nesse sistema.

Notamos que a expansão é conferida nos vértices correspondentes à comunidade, entendida como base social e coletiva do sistema de atividade; às regras como convenções tácitas reguladoras das ações e interações; à divisão do trabalho, como a divisão e compartimentação de ações entre os membros da comunidade (Engestrom, 1999; Daniels, 2003; Cedro, 2008).

As setas em forma de raios posicionadas entre os vértices representativos dos meios ou artefatos mediacionais e objeto, e entre os vértices objeto e divisão de trabalho, "indicam contradições entre as componentes centrais do sistema de atividade" (Engestrom, 1999, p. 31). Para o autor, tais contradições se constituem como perturbações indicadoras de potenciais de mudanças e desenvolvimento.

O princípio de destaque do sistema coletivo de atividade é o caráter colaborativo e dialógico que rege as relações entre as pessoas que atuam em tal sistema, sendo esse visto em suas relações de rede com outros sistemas de atividade. A grande questão discutida por Engestrom, da qual origina a ideia de coletividade do sistema, é se determinado objeto pode ou não ser compartilhado em uma atividade. Com o amadurecimento dessa discussão, ele argumenta a favor do compartilhamento com a ideia de que o alcance do objeto se perfaz em um processo coletivo, por meio de ações individuais e grupais, “[...] pela negociação e orquestração e pela luta constante entre diferentes metas e perspectivas de seus participantes" (Engestrom, 1999b, apud Daniels, 2003, p. 119). Em uma atividade, inserida em um sistema coletivo, o sujeito assume ora a personalidade de indivíduo, ora a personalidade de membro de um grupo. Em tal condição, "o objeto e o motivo de uma atividade coletiva são algo como um mosaico em constante evolução, um padrão que nunca está inteiramente acabado" (idem).

Outro princípio fundamental intrínseco ao mecanismo do sistema coletivo de atividade é a colisão e fusão das diferentes vozes e opiniões advindas das variadas comunidades e práticas coexistentes. Referimo-nos à multivocalidade como fonte de contradições e inovações, sobretudo no processo de divisão de trabalho, o que exige dos participantes constantes avaliações e rearticulações das opiniões e ações. "Um sistema de atividade é sempre uma comunidade de múltiplos pontos de vista, tradições e interesses" (Daniels, 2003, p. 124). Tradições e interesses marcados pelas histórias de vidas próprias de cada participante do sistema e da rede, na qual o sistema é inserido. 
O terceiro princípio sugerido por Engestrom é a historicidade dos sistemas de atividade, os quais são considerados como mutáveis no decorrer dos tempos históricos. Não apenas os participantes possuem sua história, mas cada atividade, como também seus artefatos mediadores e objetos. Não é possível estudar uma atividade sem considerar a história de seu contexto local, pessoas, instrumentos/ferramentas que a molda. Nessa dimensão, o estudo de qualquer atividade exigiria a consideração sobre a história de seus conceitos, de seu contexto local, dos instrumentos mediadores das ações de seus sujeitos, das histórias pessoais, entre outros.

A valorização do papel das contradições, vistas como fontes de mudança e de desenvolvimento, sintetiza o quarto princípio do sistema de atividade. Para Daniels (2003), as contradições não são sinônimas de problemas ou conflitos, mas correspondem às tensões estruturais historicamente acumuladas no sistema. Em um sistema existem contradições primárias e secundárias. Em nosso entendimento, as contradições primárias são aquelas que entrelaçam os elementos centrais da atividade. Por exemplo, no caso do trabalho docente, a atividade primária seria a relação sentido/significado nos planos individual e coletivo, aquela relação que estruturalmente nos fala do padrão de alienação do professor e da profissão docente; contradições secundárias seriam geradas pela introdução de um modo de mediação com certo grau de impacto sobre a prática do coletivo, o que de certo modo poderia gerar conflitos. A relevância desse princípio está no fato de que as contradições de qualquer natureza têm o potencial de promover mudanças nos planos individual e coletivo do sistema.

O quinto e último princípio em destaque discute a possibilidade de transformações cíclicas e qualitativas nos sistemas de atividade: questionamentos individuais, decorrentes do agravamento de contradições ou do aflorar de conflitos, podem evoluir para o plano coletivo e exigir um "deliberado esforço de mudança coletiva". Em tal caso, "o objeto e o motivo da atividade são reconceituados para abraçar um horizonte radicalmente mais amplo de possibilidades do que no modo anterior de atividade” (Daniels, 2003, p. 125). Numa visão ainda mais ampla, poderíamos afirmar que esse processo de transformações qualitativas assume um caráter que extrapola o limite da Zona de Desenvolvimento Proximal de um indivíduo, com alcance de incidência sobre a ZDP do coletivo em atividade.

Para analisarmos o caso da professora ilustrado anteriormente, em que sua ação foi transformada em atividade, em um sistema coletivo de atividade regido sob tais princípios, necessitaríamos de outros liames para o entendimento dos elementos e contradições inerentes às mudanças qualitativas em seus motivos. Qual o conteúdo das vozes ouvidas pela professora? Quais elementos suscetíveis a mudanças constam de sua trajetória profissional? 
Sob quais regras e condutas se organizam os sujeitos da escola? Quais princípios teóricos e metodológicos orientam a realização do processo formativo ocorrido na escola? Quais princípios políticos e educativos regem a organização do ensino? Sob quais princípios éticos a escola é gerida? Em suma, ainda que se levasse em conta o percurso do desenvolvimento da referida professora em detrimento do percurso das demais professoras da escola, os múltiplos aspectos do sistema coletivo de atividade, no qual se assenta o funcionamento da escola, devem ser considerados. Por suposto, possivelmente daríamos conta de que as transformações em seus motivos dependem, substancialmente, de processos interpessoais vivenciados por ela no coletivo do sistema, a considerar sua trajetória formativa e profissional, os quais foram pouco a pouco se internalizando e se constituindo como intrapessoais.

Com esse exemplo, damos uma pequena demonstração da complexidade dos objetivos desta investigação - focalizar o desenvolvimento profissional docente no exercício da docência. A Teoria da Atividade é o nosso principal ponto de apoio teórico, a considerar seus princípios essenciais pressupostos por Leontiev, ampliados e valorizados por Engestrom, ao propor as subsequentes gerações, sintetizadas no sistema coletivo de atividade.

Abordamos a seguir mais dois importantes conceitos encontrados no eixo central dessa teoria, cuja relevância se coloca, sobretudo por favorecerem a compreensão, não apenas da estrutura da consciência, mas do próprio desenvolvimento do psíquico humano. Estamos nos referindo aos conceitos de significado ou significação social e sentido, explorados na análise circunscrita a este trabalho sobre o desenvolvimento profissional docente.

\subsubsection{Significado e sentido na Teoria da Atividade}

Significado e sentido são termos muito usados como sinônimos na linguagem cotidiana, sobretudo no campo da educação. Na obra de Vigostski, esses dois conceitos são introduzidos como distintos um do outro.

Para Vigotski (2009) o significado encerra-se na generalização do conceito que, por sua vez, consubstanciado na palavra, compõe um sistema estável. O sentido, por sua vez, é mutável e inconstante. Esse autor discute mais detidamente sobre esses conceitos a partir de estudos feitos pelo psicólogo francês Frédéric Paulhan:

(...) o sentido é sempre uma formação dinâmica, fluida, complexa que tem várias zonas de estabilidade variada. O significado é apenas uma dessas zonas do sentido que a palavra adquire no contexto de algum discurso e, ademais, uma zona mais estável, uniforme e exata. Como se sabe, em contextos diferentes a 
palavra muda facilmente de sentido. O significado, ao contrário, é um ponto imóvel e imutável que permanece estável em todas as mudanças de sentido da palavra em diferentes contextos (Vigotski, 2009, p. 465).

Em acordo com Vigotski, Luria (2001, p. 45) diz:

Por significado, entendemos o sistema de relações que se formou objetivamente no processo histórico e que está encerrado na palavra. (...) O 'significado' é um sistema estável de generalizações, que se pode encontrar em cada palavra, igualmente para todas as pessoas. Este sistema pode ter diferente profundidade, diferente grau de generalização, diferente amplitude de alcance dos objetos por ele designados, mas sempre conserva um 'núcleo' permanente, um determinado conjunto de enlaces.

Luria explicita o que é sentido:

(...) Por sentido, entendemos o significado individual da palavra, separado deste sistema objetivo de enlaces; este está composto por aqueles enlaces que têm relação com o momento e a situação dados (2001, p. 45).

Nessa abrangência teórica, significado encerra-se na palavra com uma conotação verbal e adquire uma abrangência social ao ser compreendido como o modo em que o conceito ou o conhecimento é apropriado coletivamente pela humanidade; enquanto o sentido é como o indivíduo toma para si tal significado, dando-lhe o conteúdo de sua vivência pessoal, cultural e afetiva. A fluidez, mutabilidade e inesgotabilidade do sentido se justificam por sua dependência em relação à variabilidade do contexto e ao conteúdo pessoal que lhe é atribuído pelo sujeito.

Luria, em seu livro Pensamento e Linguagem, exemplifica esses conceitos aplicandoos à palavra "carvão". Segundo esse autor, essa palavra possui "um significado formado objetivamente ao longo da história e que, em forma potencial, conserva para todas as pessoas" - carvão é um "objeto preto, na maioria das vezes de origem vegetal, originado da calcinação das árvores, com uma determinada composição química em cuja base está o elemento $\mathrm{C}$ (Carbono)". O sentido da palavra "carvão" difere de pessoa para pessoa: para a dona de casa, é um material que garante o aquecimento do ambiente; para o cientista, é um objeto de estudo; para o pintor, é um instrumento de trabalho; e para uma menina que tem o seu vestido branco sujo pelo carvão, essa palavra tem um sentido não agradável (Luria, 2001, p. 45).

Para Leontiev (1978), significado ou significação (denominação dada a esse conceito por esse autor) e sentido se constituem na própria estrutura da consciência humana. O quadro 
do mundo aparece ao sujeito em sua significação, enquanto o sentido é o que esta significação é para o sujeito. Leontiev esclarece:

"A significação é a generalização da realidade" (...) "refletida e fixada na linguagem, o que lhe confere a sua estabilidade".

“A significação (...) é a forma ideal, espiritual da cristalização da experiência e da prática sociais da humanidade. A sua esfera das representações de uma sociedade, a sua ciência, a sua língua existem enquanto sistemas de significação correspondentes" (1978, p. 94).

Leontiev deixa ainda mais claro tal conceito quando afirma que "a significação é o reflexo da realidade independentemente da relação individual ou pessoal do homem a esta" (1978, p. 96). Ou seja, o sujeito ao nascer encontra um determinado sistema de significações, do qual pode ou não se apropriar e com o qual pode ou não contribuir a partir das atividades que desenvolverá no decurso de sua vida.

O conceito de sentido reside no modo como o sujeito se apropria ou não dessas significações, de como elas farão ou não parte de suas atividades, de sua consciência e personalidade, pois “(...) o sentido é antes de mais nada uma relação que se cria na vida, na actividade do sujeito" (Leontiev, 1978, p. 97). A significação, ao ser apropriada, passa a ter um sentido pessoal para o sujeito, passa a pertencer aos domínios de sua consciência individual. Como o próprio Leontiev diz, "o sentido pessoal traduz precisamente a relação do sujeito com os fenômenos objectivos conscientizados" (idem, p. 98).

Não há distância entre as abordagens de Vigotski, Luria e Leontiev sobre os conceitos significado e sentido. Entretanto, em nossa interpretação, Leontiev amplia o nível de compreensão desses conceitos ao relacioná-los mais claramente à estrutura da consciência e da atividade. Na estrutura da atividade, o motivo se realiza no objetivo, assim como o sentido expressa a significação. O motivo está intrinsecamente ligado ao objetivo do mesmo modo que o sentido se interliga à significação. Podemos dizer, então que a significação está para o objeto ou objetivo, como o sentido está para o motivo. Como afirma Asbahr, 2005, p. 53:

Sentido pessoal e motivo estão intimamente relacionados e, para que possamos encontrar o sentido, devemos descobrir seu motivo correspondente, pois o sentido é produzido na relação entre o motivo da atividade e o objeto para o qual dirige-se a ação, isto é, o fim consciente da ação. O sentido pessoal indica, portanto, a relação do sujeito com os fenômenos objetivos conscientizados. 
Com base em Leontiev, ressaltamos a relação motivo/sentido para além de uma relação íntima, com a ideia de que os motivos geram sentidos:

O desenvolvimento dos sentidos é um produto do desenvolvimento dos motivos da atividade; o desenvolvimento dos próprios motivos da atividade determina o desenvolvimento das relações reais do homem com o mundo, condicionadas pelas circunstâncias objetivas e históricas de sua vida (1983, p. 230).

O sentido reflete a objetivação dos motivos na obtenção dos objetivos; reflete, por assim dizer, a satisfação das necessidades materiais e espirituais, processo do qual se origina o motivo. Necessidades satisfeitas, objetivos alcançados são elementos que se consolidam na consciência do sujeito como uma forma de afirmar sua vida, refletidos no conteúdo do sentido construído.

Supomos, portanto, que planejar uma ação, desenvolvê-la, obter sucesso nesse desenvolvimento e atingir objetivos pretendidos, são elementos que levam, por exemplo, à autoafirmação profissional, isto é, à objetivação de motivos, os quais se coadunam em sentidos pessoais relacionados à significação social da profissão em questão.

Em síntese, relembramos que a construção de sentidos é um processo contínuo e transitório e completamente relacionado à formação da consciência e personalidade humana. A construção de sentidos não prescinde do reconhecimento dos modos como se vive e das condições sob as quais a vida acontece, bem como da significação social de sua atividade. Assim, reafirmamos que em uma atividade, objetivo e motivo são coincidentes, assim como significação e sentido são correspondentes.

Em suma, trabalho tal qual é definido por Marx e atividade no sentido que lhe é atribuído por Leontiev, são processos que se complementam, tornam-se um só, uma vez que ambos são estruturados pela necessidade, pelo objetivo/significação e pelo motivo/sentido. Trabalho como atividade humana cumpre o papel de produzir meios ou instrumentos a fim de satisfazer necessidades, as quais se materializam no objeto alcançado e produzido, tornandose fonte de conhecimentos, cultura e habilidades apropriadas pelos homens no curso de sua história de vida. Homens em atividade se autotransformam, se desenvolvem psiquicamente, formam a sua consciência e personalidade, constroem a sua própria história e a história da humanidade. 
Perguntamos, porém: no decurso da formação da consciência humana pari passu ao desenvolvimento da humanidade, a atividade humana sempre se estrutura pela correspondência entre significação e sentido? O trabalho sempre se configura como atividade humanizadora?

É o que discutiremos no próximo tópico.

\subsection{Trabalho, atividade e consciência e alienação}

Com o apoio de Leontiev e de outros estudiosos, respondemos negativamente à questão acima.

Não há diferenciação entre a significação e o sentido na consciência humana nos primeiros estádios da sociedade, quando ainda não havia divisão social do trabalho e muito menos a exploração do homem pelo homem. A comunidade primitiva era regida pela propriedade coletiva, cujos meios de produção e seus respectivos produtos não eram separados de quem os produziam. Assim como o trabalho, os produtos resultantes deste eram comuns e apropriados coletivamente. Nessas condições, fazia significado e sentido produzir tanto numa conotação social objetiva como na esfera da subjetividade para cada um dos membros daquela sociedade.

Entretanto, a divisão social do trabalho e a propriedade privada produziram num contexto histórico mudanças qualitativas e quantitativas na estrutura da consciência humana, em que a significação social do trabalho é dissociada do sentido que lhe é atribuído pelo trabalhador. Como bem disse Leontiev, “(...) uma transformação radical das relações de produção acarreta uma transformação não menos radical da consciência humana" (1978, p. 91).

Estamos nos referindo à sociedade capitalista, cuja lógica é a reprodução do capital, na qual o trabalho se forja na relação de exploração, em que uma minoria, os exploradores, detém os meios de produção, e a maioria, os trabalhadores ou produtores, são destituídos desses meios de produção e do próprio produto de seu trabalho. O único bem que verdadeiramente pertence ao trabalhador é a sua força de trabalho, a qual é vendida ao capitalista em troca do seu salário - valor recebido por parte da jornada de trabalho, correspondente ao tempo de trabalho necessário à satisfação das necessidades relativas à sua sobrevivência. A outra parte da jornada equivale ao tempo de trabalho excedente, cuja 
produção é apropriada pelo capitalista na forma de mais-valor ou mais-valia - fonte de riqueza do modo de produção capitalista (Marx, 2004; 1985).

Engendra-se nessa relação social nada menos que a alienação do trabalho, em que o trabalho, exteriorizado da natureza humana, não mais se consubstancia como a "satisfação de uma necessidade, mas apenas como um meio para satisfazer outras necessidades" (Marx, 2010, p. 83). Sem o domínio sobre a totalidade do processo de trabalho, o trabalhador é responsabilizado por apenas uma de suas partes, muitas vezes de caráter repetitivo e mecânico, que em nada contribui com a sua formação intelectual e profissional. Desse modo, o trabalho passa a negar a essência humana: o trabalhador não mais se realiza no trabalho, ao contrário, deseja evitá-lo como a "uma praga" pois esse passa a ser "um trabalho de sacrifício próprio, de mortificação" (Marx, 2010, p. 83).

Instaura-se um paradoxo - o trabalho continua sendo a fonte de toda a riqueza da humanidade, enquanto o trabalhador, sujeito dessa atividade, é colocado fora do processo de produção, em virtude de não mais se reconhecer no produto de seu trabalho, agora, lhe apresentado como algo alheio e independente (Sánchez Vázquez, 2007). Ademais, a apropriação dessa riqueza material e de todo o seu valor cultural e intelectual não é mais coletiva - esse patrimônio que deveria ser de todos os seres humanos, passa a ser apropriado de modo privado por uma minoria, na qual, lógico, o trabalhador não se faz presente (Duarte, 2004).

Visualiza-se algo que é consequência dessa alienação, qual seja, "a discordância entre o resultado objetivo da atividade humana e o seu motivo" (Leontiev, 1978, p. 122). O sentido ou conteúdo subjetivo da atividade de trabalho, ou seja, o que ela realmente é para o trabalhador, não mais coincide com a sua significação ou com o seu conteúdo objetivo. A ação humana está completamente dissociada do objetivo ou direção para qual ela se dirige. $\mathrm{O}$ sentido dessa ação para o trabalhador não é nada mais do que ganhar o salário, que "é determinado pelo quanto ele recebe e não pelo o que ele produz" (Duarte, 2004, p. 57).

A ruptura entre significação social e sentido apresenta-se na cisão do processo de trabalho em sua totalidade: criação/imaginação e ação estão em campos distintos e realizados também por pessoas diferentes - quem pensa, cria e imagina, não faz; e quem faz não é quem pensou, criou e imaginou. Tem-se, então, alienado do trabalhador a essência do trabalho em seu caráter humano - o plano a nível mental, isto é, a atividade teórica. 
Quebra-se a unidade teoria/prática imprescindível à constituição da atividade humana como práxis, posto que essa se traduza, exatamente, na inseparabilidade entre a teoria e a prática. A teoria depende da prática para se realizar, se plasmar, para produzir mudanças reais (Sánchez Vázquez, 2007). Segundo esse autor, para produzir uma mudança real,

(...) não basta desenvolver uma atividade teórica, é preciso atuar praticamente. Ou seja, não se trata de pensar um fato, e sim de revolucionálo; os produtos da consciência têm de se materializar para que a transformação ideal penetre no próprio fato. Assim enquanto a atividade prática pressupõe uma ação efetiva sobre o mundo, que tem como resultado uma transformação real deste, a atividade teórica apenas transforma nossa consciência dos fatos, nossas ideias sobre as coisas, mas não as próprias coisas (idem, p. 239).

Ou seja, a dissociação entre a atividade teórica e a atividade prática implica na alienação do homem em relação a si mesmo e a outro homem, tornando-se um obstáculo ao desenvolvimento humano nos planos psíquico e profissional. Aliena-se do homem a sua capacidade imaginativa e criadora, restando-lhe a execução e a contínua reprodução do pensamento e do planejamento alheio. Eis porque Leontiev nos diz da entrada dessas relações na consciência humana, em que se produz a ruptura sentido e significação; eis porque Marx nos fala da mortificação pelo trabalho; eis porque Asbahr (2011, p. 92) nos lembra de que tais contradições produzidas na consciência podem acarretar "grandes sofrimentos psíquicos e, no limite, o adoecimento psicológico".

Para Duarte (2004), a ruptura entre o sentido do trabalho e a sua significação social não acontece apenas para o trabalhador, mas também para a sociedade. Isto é explicado pelo fato de que o sentido que o trabalho tem para o trabalhador não é produzido por ele próprio, mas é consequência do sentido que o conteúdo do trabalho tem para a sociedade. $\mathrm{Ou}$ seja, esse sentido é produzido socialmente e culturalmente, cuja mudança, portanto, não depende apenas do indivíduo isoladamente. Romper com o conteúdo alienante do sentido do trabalho no nível da sociedade requer a formação de uma nova consciência humana, somente possível com a superação das relações sociais do atual modo de produção, o que culminará com uma nova organização social.

Todavia, o caráter inquietante da personalidade humana e a mutabilidade intrínseca à consciência humana e aos sentidos e motivos que a move, bem como o caráter dialético que emana de toda e qualquer situação da natureza humana, impulsionam o homem à construção de novos sentidos mesmo na complexidade da atual organização social. O conteúdo desta reflexão nos mobiliza e nos conduz para as possibilidades de construção de novos sentidos, o 
que a nosso ver se torna possível a partir da organização de grupos nos locais de trabalho, da realização de projetos colaborativos e da tomada de consciência pelos participantes do conteúdo alienante de seu trabalho. Em acordo com Martins (2004, p. 98), "a luta contra a alienação apenas começa quando sua existência é reconhecida e assumida, então não mais de forma passiva, porém crítica".

Ainda que essa construção gradativa de sentidos não tenha a amplitude necessária à consolidação de uma nova ordem social, guarda singular importância do ponto de vista da formação de uma nova consciência para aqueles que, ao reconhecerem suas condições e modos de vida, buscam em sua atividade profissional correspondência entre o sentido que ela tem para si e a sua significação social.

O trabalho docente não se exime de tais reflexões. Apesar de suas especificidades, situa-se, como qualquer outra atividade laboral, no limiar da atividade como prática social ou práxis e do trabalho historicamente e culturalmente alienado. Prosseguiremos com essas reflexões a partir da abordagem de algumas das particularidades dessa atividade - sua natureza social e econômica para nos municiarmos de subsídios que nos possibilitem ampliar a discussão sobre o desenvolvimento profissional docente.

\subsection{Sobre o trabalho docente}

Buscamos analisar o trabalho docente na amplitude da categoria trabalho humano, com a intenção de ressaltar suas peculiaridades, principalmente no nível da educação básica na escola pública. Sem pretender aprofundar, discutimos a sua natureza econômica e aspectos relativos ao objeto de trabalho, no caso o ser humano.

Em relação à natureza econômica do trabalho docente, nos detemos em alguns aspectos para que possamos inseri-lo na cadeia social, econômica e política da lógica que rege a sociedade capitalista. Nessa lógica, o professor é um trabalhador assalariado que, como tantos outros, vende a sua força de trabalho para receber em troca o correspondente monetário, com o qual procura garantir o seu sustento. $\mathrm{O}$ trabalho docente é usufruído na forma de serviços, ou seja, é classificado como não material, e como tal, nem sempre se configura como produtivo e, subsequentemente, nem sempre tem uma relação direta com a produção do capital. As relações produtivas variam de como e de quem compra os serviços do professor. Nas palavras de Marx (2004, p. 115): 
Um mestre-escola que ensina outras pessoas não é um trabalhador produtivo. Porém um mestre-escola que é contratado com outros para valorizar, mediante o seu trabalho, o dinheiro do empresário da instituição que trafica conhecimentos (Knowledge mongering institution. Ing.) é um trabalhador produtivo.

As relações produtivas de professores que trabalham em escolas privadas são distintas daquelas estabelecidas por professores da rede pública. De acordo com Marx (2004), com Serrão (2002) e com Asbahr (2005), o professor da escola privada vende sua força de trabalho ao proprietário da escola que, por sua vez, vende os serviços educacionais prestados como uma mercadoria aos estudantes, adquirindo em troca um valor muito maior do que aquele correspondente ao salário pago ao professor. Desse modo, esse profissional gerou um valor excedente, o qual compõe a fonte de riqueza do capitalista que o contratou. Enquanto que o professor da escola pública não participa diretamente da produção capitalista, pois os seus serviços contratados pelo Estado não são vendidos aos estudantes e não geram nenhuma grandeza excedente. Contudo, nem por isso o professor da escola pública deixa de ser um trabalhador explorado como o é o professor da escola privada, pois como assalariado, o valor de seus serviços nem sempre são pagos na justa medida.

Outro aspecto importante é o fato de que nem o professor da escola pública e nem o professor da escola privada, ainda que estabeleçam relações produtivas e sociais distintas, não são detentores dos meios de produção, pois um e outro necessitam vender a sua força de trabalho para sobreviver (Serrão, 2002). Também o produto de seu trabalho não lhes pertence, uma vez que esse produto - a aprendizagem ou o aprendido - está completamente incorporado ao estudante, e vai com ele para além da escola.

Outra diferença substancial do trabalho docente em relação ao trabalho material é o seu objeto de trabalho - o ser humano - aspecto central por revelar traços essenciais da natureza da atividade, bem como do professor e da qualidade das relações estabelecidas em seu processo de realização. Como afirmam Tardif \& Lessard (2005, p. 31), “ensinar é trabalhar com seres humanos, sobre seres humanos, para seres humanos". Configura-se, assim, um modo de relação altamente complexa entre sujeitos.

Todavia, Asbahr (2005, p. 30), nos adverte que o estudante não pode apenas ser colocado como objeto de trabalho do professor, pois desse modo corremos o risco de cairmos num determinado reducionismo. Para essa autora, o educando é ao mesmo tempo objeto de trabalho e sujeito de sua educação, pois "participa ativamente do seu processo de 
aprendizagem e só pode aprender como coprodutor dessa atividade", como "sujeito da atividade de aprendizagem".

Para Asbahr (idem), o professor conta com um objeto de trabalho que é um "ser de vontade", um ser que nem sempre está disposto a ir para a escola ou a aprender; um ser ativo, que polemiza, questiona as relações de poder; um ser que resiste ao objetivo e à ação do professor. Essa autora enfatiza que o desejo de aprender não é um valor natural, e sim construído historicamente, cuja construção é inerente ao processo de ensino, sendo o professor o principal responsável.

Lembramos ainda que o objeto de trabalho do professor em uma sala de aula não é um estudante, mas muitos, o que pluraliza e heterogeneiza as vontades, as dúvidas, as angústias, os questionamentos, complexificando ainda mais a atividade desse trabalhador. Não há dúvida quanto ao caráter inter-relacional dessa atividade, diga-se de passagem, também pluralizadas, construídas a várias mentes, a várias mãos e a sabores e dissabores.

Não podemos esquecer que o professor não se relaciona somente com seus alunos, pois outras pessoas fazem parte da rede de inter-relações, como seus colegas, os familiares dos alunos, gestores das escolas, representantes de instâncias formativas, e outros. Lembramos que a participação da comunidade escolar na gestão da escola é garantida por lei, ainda que essa prerrogativa não se efetive substancialmente em todas as escolas (Costa, 1996).

Por ser um trabalho de inter-relação, a docência é essencialmente um trabalho de mediação. A atuação do professor sobre seus alunos é mediada por diferentes modos, entre os quais destacamos a linguagem, sendo esta aqui concebida, em sua dimensão semiótica, como o principal instrumento do trabalho docente, responsável pela mediatização da comunicação e das relações entre os sujeitos e, por conseguinte, da construção de significados.

E o conhecimento? Qual papel exerce na atividade docente? Linguagem e conhecimento são indissociáveis por comporem e mediarem as inúmeras ações da atividade pedagógica, seja na esfera do planejamento, seja na esfera do desenvolvimento em sala de aula. Ação, linguagem e conhecimento são, a um só tempo, instrumentos e matéria prima do professor, os quais são objetivados no objeto e produto final do trabalho - estudantes modificados, ou seja, imbuídos de novos significados.

Nesse sentido, afirmamos que teoria e prática são imanentes à força de trabalho docente, por concebermos a atividade teórica/prática como o núcleo essencial dessa profissão, 
por não querermos imaginar e conceber um professor que não tenha em sua mente o plano de seu trabalho antes de realizá-lo, sem que o realize com propriedade sobre seus saberes. Como já abordamos anteriormente, a separação entre a teoria e a prática compromete a identidade humana e o trabalho como práxis criadora e transformadora, ou seja, a docência desprovida do núcleo teoria/prática se constituiria em trabalho alienado.

No âmbito da configuração do conteúdo alienante ou não alienante da docência, diferentes aspectos podem ser considerados. Em relação à sua profissionalização, por exemplo, o professor vive hoje uma situação paradoxal. Ao mesmo tempo em que se propala a importância de seu papel na formação dos jovens para enfrentar os desafios da "sociedade da informação e da globalização" e se ouvem os clamores vindo de intelectuais e pesquisadores por sua valorização (Nóvoa, 1999), os professores são culpabilizados publicamente pelos altos índices de reprovação dos estudantes nas avaliações externas; são olhados com desconfiança; cobrados por uma melhor formação e atualização dos seus conhecimentos e práticas frente às novas tecnologias e novas propostas metodológicas.

Sem dúvida, a retórica dos discursos favoráveis à valorização da docência é ambígua em relação à verdadeira face das políticas públicas, por essas não deliberarem pela efetivação de uma educação pública viabilizada de modo sistêmico e respeitada tal qual à sua importância social. Concomitantemente a essa "pobreza das práticas públicas” (Nóvoa, 1999, p. 13), o que vemos são obstáculos à constituição da docência como uma profissão e do professor como um profissional com controle sobre o seu processo de trabalho.

Na realidade, esses obstáculos refletem a posição da docência na cadeia econômica e política da sociedade, bem como o valor social e cultural que é atribuído à educação, o qual está associado ao status social e cultural do professor. Os salários baixos que subjugam o professor à intensificação de seu trabalho por meio do acúmulo de jornadas, e as condições de trabalho nas escolas, como número excessivo de alunos em classe, falta de recursos, falta de segurança, entre outros aspectos, são alguns dos reflexos da desvalorização da função social da educação e, particularmente, da perda do status profissional do professor e do reconhecimento social de sua experiência (Almeida, 1999; Costa, 1996).

O modo hierarquizado e burocrático tal qual o ensino é organizado reforça a dicotomia concepção-execução, por limitar cada vez mais a autonomia docente e o próprio controle sobre suas ações pedagógicas (Azzi, 2005; Almeida, 1999). Romper o núcleo teoria/prática no âmbito da profissão docente não é nada mais do que alienar o professor não apenas de instrumentos de trabalho importantes, como o pensamento e o conhecimento, mas 
quebrar um dos pilares que constitui a sua atividade como auto criadora e auto transformadora.

O isolamento do professor em seus processos de formação é outro aspecto que merece atenção. Fora de um circuito formativo, esse profissional passa a buscar por conta própria seus recursos formativos, os quais muitas vezes não respondem às suas necessidades (Cunha, 1999). Em certa medida, muitos programas de formação continuada também não se enquadram entre as melhores soluções para a superação das dificuldades formativas do professor no decurso de sua atividade profissional.

Sob impacto desses fatores objetivos, o professor, impossibilitado de realizar o seu motivo no objeto de seu trabalho, vai esvaziando as suas ações e atribuindo à sua atividade pedagógica um sentido não correspondente à significação social de sua profissão, ou seja, o motivo que o impele vai se afastando do objetivo para o qual a sua ação se dirige. Isto é, o sentido de suas ações se perfaz na venda de sua força de trabalho com o objetivo não de criar oportunidades de aprendizagem para os seus alunos, mas apenas de receber seu salário no final do mês.

Em tal situação, a subjetividade do professor é afetada, seus motivos e sentidos são postos a prova cotidianamente, a ponto de leva-lo até ao adoecimento psicológico, como o estresse ou o mal-estar docente, conhecida como síndrome de burnout ${ }^{4}$ ou síndrome da desistência. Subjugado a essa situação, o professor não "se afirma mais em seu trabalho, mas nega-se nele, que não se sente bem, mas infeliz, que não desenvolve energia física e espiritual livre, mas mortifica a sua physis e arruína o seu espírito” (Marx, 2010, p. 82-83).

Em suma, a cisão entre teoria e prática, a destituição do professor de instrumentos de trabalho como conhecimento e pensamento, a perda de seu domínio sobre o processo e produto de seu trabalho, bem como os demais elementos objetivos e subjetivos supracitados, configuram um quadro de alienação do trabalho docente. Como já afirmamos antes, esse conteúdo alienante do trabalho pode comprometer não apenas a qualidade do ensino, mas o próprio desenvolvimento profissional do professor, pois "a sua atividade não concorrerá para o seu enriquecimento subjetivo", e não mais lhe propiciará o aprimoramento de seus conhecimentos e nem lhe permitirá a sua realização como "gênero humano" (Basso, 1998, p. 08).

\footnotetext{
${ }^{4}$ Sobre a síndrome de burnout, consultar: CODO, W. \& VAZQUES-MENESES, I., O que é burnout? In: CODO, W. (coord). Educação: carinho e trabalho. Petrópolis, RJ: Vozes, 1999.
} 
O reconhecimento desse quadro nos conduz a refletir sobre caminhos que levariam a possiblidades de revertê-lo, se não totalmente, pelo menos parcialmente. Embora não se vislumbre a unidade sentido-significado numa perspectiva coletiva e social sem que as relações capitalistas sejam completamente superadas, necessário se faz atuar nos núcleos de resistências que subsistem no próprio espaço dialético da alienação: o que à primeira vista se aparenta como caos, tem em si engendrado a sua própria contradição e negação.

Professor, uma vez consciente de sua condição de trabalhador explorado, das circunstâncias históricas, politicas e econômicas nas quais ele e sua categoria profissional estão envolvidos, e dos elementos que o aliena ou o separa do trabalho como atividade humana e criadora, poderá passar a negá-los e a buscar espaços de atuação e superação. São, exatamente, esses elementos de contradição e de negação que podem se constituir como motivos que conduzem os sujeitos à ação e à mudança de realidade.

Contudo, concomitantemente a essa tomada de consciência sobre sua realidade, é imprescindível que o professor reconheça também o seu papel na efetivação da significação social da docência, o de "mediador entre o aluno e o patrimônio intelectual mais elevado da humanidade" (Duarte, 2010, p. 38). A significação social de sua docência não é senão criar oportunidades para que os estudantes se apropriem desse patrimônio composto pelo conjunto de significados sistematizados ao longo da produção científica da humanidade (Saviani, 2007). A efetivação dessa significação associa-se ao compromisso ideológico do professor com a valorização da escola pública e do trabalho docente nos princípios da educação humanizadora.

\subsubsection{Espaços de construção de novos conteúdos ou sentidos para o trabalho} docente

Isso posto, criamos espaço para discutirmos sobre a construção de um novo conteúdo ou de novos sentidos para o trabalho docente que superem o conteúdo da alienação. A nosso ver, essa construção não passa por reconfigurar a vida profissional de um professor isoladamente, posto que por essa via nenhum passo se daria para a objetivação da docência como prática social ou como práxis humana. Ao contrário, passa, em certa proporção, pela constituição de grupos de professores em seus ambientes de trabalhos dispostos a solidificar um trabalho coletivo e colaborativo orientado por posturas reflexivas e críticas, tanto no que 
diz respeito às proposições metodológicas realizadas em sua prática, como à humanização das relações entre pares e com seu objeto de trabalho - seus alunos.

Pesquisas no campo da formação contínua de professores têm apresentado resultados que reforçam o valor do trabalho colaborativo como mediador do processo de organização do ensino e, por suposto, dos modos de aprendizagem docente que emergem no contínuo do exercício profissional. Para Araújo (2003, p. 166), tanto os modos de aprendizagem docente como os modos de organização da escola e do ensino estão associados às relações profissionais baseadas na "cultura da coletividade".

Entretanto, a cultura da coletividade não se trata de uma situação dada entre os professores. Segundo Pimenta (2005) construir tal cultura nas relações profissionais docentes tem sido difícil, uma vez que os valores que sustentam a sociedade atual se proliferam em sentido oposto, no sentido da individualização e da competitividade entre as pessoas, os quais estão refletidos nas dificuldades de estabelecimento de projetos compartilhados entre professores. Para essa autora, a individualidade é "altamente estimulada pelo sistema de ensino por meio da fragilidade de um precário estatuto de profissionalidade" (Pimenta, 2005, p. 537-538), visualizada nas próprias condições de trabalho do professor.

Portanto, necessário se faz recuperar o conceito de cultura da coletividade no seio dos projetos colaborativos centrados na escola que visam a formação contínua de professores, assim como, a concepção da escola como uma "comunidade de aprendizagem", como um lugar onde se aprende, no qual "participam vários actores sociais que nela desempenham papéis activos, embora diversificados” (Alarcão, p. 81, 2005). Sob essa concepção, a escola torna-se um espaço onde diferentes sujeitos se encontram cada um com suas experiências e modos de acessos à cultura e aos conhecimentos produzidos e valorizados pela humanidade; o encontro desses sujeitos e desses conhecimentos resulta em processos de aprendizagem e de ressignificação de conhecimentos para todos os participantes (Penteado, 2010) e, por conseguinte, abre possibilidades para o desenvolvimento profissional.

Em nome da organização do ensino e da formação docente, mediadas por projetos colaborativos, discutimos em estudo anterior (Azevedo, 2008), sobre as possibilidades de elaboração de saberes docentes criadas por um processo formativo em ensino de ciências, organizado metodologicamente como uma pesquisa-ação, sendo esta praticada por meio de Atividades Investigativas de Ensino (AIE). Mediatizada pelo projeto político pedagógico da escola, as AIEs tornaram-se núcleos organizadores das ações educativas em ciências, capazes de gerar entre as professoras envolvidas ciclos autorreflexivos próximos aos que pressupõe 
uma pesquisa-ação, movimentados pelos atos de planejar, desenvolver e avaliar. Esse movimento trouxe em si o potencial da reorganização do ensino e da atuação docente, no sentido da reaproximação entre a teoria e a prática. Na dimensão da pesquisa-ação, necessidades organizativas e formativas emergem do processo de resolução dos problemas de ensino eleitos como essenciais pelas próprias professoras, entre as quais destacamos as práticas colaborativas como os elementos mais eficazes do ponto de vista de se tornar viável a reorganização do ensino e, por conseguinte, desencadear a aprendizagem docente. Professores em colaboração uns com outros resolvem problemas, realizam práticas com resultados avaliados positivamente.

A Atividade Investigativa de Ensino (AIE) incorpora elementos teóricos da Atividade Orientadora de Ensino (AOE) pressuposta por Moura (1996; 2000) e outros autores, a qual, associada ao conceito de Atividade de Leontiev, contém o motivo e o objetivo desencadeadores do processo de aprendizagem do professor no âmbito da atividade de ensino e do estudante no processo de realização da atividade de aprendizagem ou de estudo. Como núcleo de ação educativa, a AOE e a AIE assumem a complexidade da articulação do ensino com a aprendizagem, se constituindo como unidade de formação do professor e do estudante. "A atividade é orientadora, no sentido de que é construída na inter-relação professor e estudante” (Moura, et all, 2010, p. 101); é orientadora pelo seu caráter intencional; por se “constituir como um modo de realização de ensino e de aprendizagem dos sujeitos" (idem, p. 97).

No bojo da discussão traçada no presente estudo, reconhecemos o potencial do projeto político pedagógico da escola, bem como dos demais instrumentos colaborativos que visam a formação contínua de professores, como os exemplos citados acima - a Atividade Investigativa de Ensino e a Atividade Orientadora de Ensino, como espaços privilegiados de atuação do professor, de compreensão de sua realidade e, por conseguinte, de construção de sentidos que sejam correspondentes à significação social de sua docência.

Embora reconheçamos a importância de uma formação continuada realizada por projetos colaborativos e da formação inicial desenvolvida com qualidade, não endossamos a ideia de que a luta pela superação da alienação do trabalho docente se restrinja ao chão da escola ou que esteja apenas nos ombros dos professores e de sua qualificação profissional. Não podemos deixar de lado os múltiplos aspectos que compõem o universo objetivo e subjetivo da profissão docente, cujas mudanças dependem não somente da implementação de políticas públicas que reflitam de modo sistêmico sobre a organização física e humana no 
âmbito da escola e do ensino, como da atuação na esfera da organização sindical e dos movimentos sociais. Por meio dessa atuação se revela a dimensão social e política dessa luta, a qual, repetimos, coaduna com a necessidade premente de organização de uma nova ordem social.

Pois bem, após localizar o trabalho docente na dinâmica social e política da atual sociedade, colocamos em pauta o desenvolvimento profissional e aprendizagem docente, processos por nós vinculados à dinâmica da docência e às suas condições de realização. Após uma abordagem geral sobre como se define desenvolvimento profissional docente, buscamos aprofundar essa conceituação a partir de sua inter-relação com as situações de aprendizagem emergentes do contínuo exercício profissional.

\subsection{Trabalho docente, aprendizagem e desenvolvimento profissional docente}

Para discutir a aprendizagem e o desenvolvimento profissional do professor, partimos de um importante referencial, o de que os sujeitos estão e se colocam em aprendizagem e em desenvolvimento por toda a vida. Obviamente, se assim não pensássemos, nenhum motivo teríamos para investigar sobre o desenvolvimento profissional docente, pois é, exatamente, por concebermos os professores, assim como concebemos o ser humano em sua generalidade, como seres inconclusos em sua dimensão histórica, intelectual e profissional, que nos debruçamos sobre o modo como se dá a sua aprendizagem e o seu desenvolvimento profissional.

Essa visão guarda coerência com a teoria histórico-cultural, mais especificamente com a Teoria da Atividade elaborada por Leontiev, a qual nos fornece subsídios para supor a docência como atividade dominante do sujeito professor em seu estágio de vida como adulto, como tal, desencadeadora de outras atividades formadas a partir das necessidades organizativas e formativas decorrentes do exercício profissional (Azevedo, 2008). Nessa dimensão teórica, o desenvolvimento profissional é atrelado à trajetória ou história de vida profissional e aos motivos que impelem o professor a construir os sentidos que atribui à sua atividade pedagógica.

Com o posicionamento do desenvolvimento profissional do sujeito no plano cultural, social e histórico, reiteramos seus estreitos vínculos com a constituição histórica da docência como profissão. Passa a ser concebido como um processo que pode evoluir nos planos 
individual e coletivo, concomitantemente, sob influência da experiência profissional e formativa da própria pessoa, do contexto político, social e cultural no qual a escola está inserida, das mudanças educativas, do modo como a escola se organiza, das condições de trabalho e dos inúmeros fatores objetivos e subjetivos que impactam a profissão docente em determinada época e lugar.

Para Marcelo (2009, p. 07) o desenvolvimento profissional se constitui na própria busca da identidade profissional, "na forma como os professores se definem a si mesmos e aos outros. É uma construção do eu profissional”. Em acordo com esse autor, visualizamos o "eu profissional”, nos planos individual e coletivo, o qual se forma, sobretudo, na relação com o outro, sendo o outro os diversos atores com quem o professor convive em seu ofício diário, a destacar os seus pares e os seus alunos.

Tal reflexão nos remete ao conceito de alteridade em Bakhtin e em Vigotski, tomado por esses pensadores como a base de toda existência humana e do desenvolvimento intelectual e cultural. Para Vigotski (2000, p.149) “passamos a sermos nós mesmos através de outros"; para Bakhtin (1997, p. 312):

Ser significa ser para outro e, através do outro, para um mesmo. O homem não possui território soberano interno; está integra e permanentemente no limite; buscando-se a si mesmo, olha nos olhos ou através dos olhos do outro [...]. Não pode fazer sem o outro; não pode ser eu mesmo sem o outro; devo encontrar-me no outro, encontrando o outro em mim (em reflexo e percepção mútua).

Com base em Vigotski e Bakhtin, reaproximamos a docência à qualidade de uma atividade humana, por estabelecermos relações entre o seu caráter de mediação com o quanto a relação interpessoal nos formam e nos tornam humanos. Parafraseando Bakhtin, diríamos que o professor, na sua condição objetiva e subjetiva de se tornar humano e profissional, existe "para o outro" e "através do outro", não faz sem o outro, encontra-se no outro e tem em si o outro.

Nessa compreensão, o desenvolvimento profissional se constitui, por excelência, como resultante das relações interpessoais que movimentam o dia a dia do exercício profissional. No âmbito dessas relações, destacamos a importância da atuação docente nos espaços coletivos, aqui considerados como núcleos articuladores favoráveis à construção de sentidos com conteúdos contrários ao caráter alienante imposto pelas condições objetivas e subjetivas sobre as quais se assentam a profissão docente na atualidade. 
A docência passa a ser compreendida como um campo de relações mediadas, tornando-se um ambiente social profícuo à aprendizagem docente e ao desenvolvimento profissional, sobretudo se tomarmos como válido o pressuposto de que o verdadeiro curso do pensamento não vai do individual para o social, mas do social para o individual, do plano externo e interpsicológico para o plano interno e intrapsicológico. Situações coletivas e colaborativas emergidas do processo de trabalho docente tornam-se imprescindíveis à ação intrapsíquica do professor e, por conseguinte, à consubstanciação de sua aprendizagem em seu desenvolvimento profissional.

Essa é a base da "lei genética do desenvolvimento cultural" elaborada por Vigotski, a qual procura explicar a formação e desenvolvimento das funções psicológicas superiores. No corpo dessa lei, as funções psicológicas superiores não são originárias do organismo e sim do meio social e correspondem às relações sociais internalizadas: "a natureza psíquica do homem vem a ser um conjunto de relações sociais trasladadas ao interior e convertidas em funções de personalidade e em formas de sua estrutura” (Vigotski, 2000, p. 151).

Chamamos a atenção para um esclarecimento importante levantado pelo próprio Vigotski: as funções psicológicas superiores ou o sistema de funções intelectuais intramentais não são cópias simples e diretas das funções intermentais ou sociais, pois há uma transformação no processo de formação do plano interno da consciência. Essa transformação resulta de uma série de eventos ocorridos ao longo do desenvolvimento. "O processo, sendo transformado, continua a existir e a mudar como uma forma externa de atividade por um longo período de tempo, antes de internalizar-se definitivamente" (Vigotski, 2010, p. 58).

A natureza dessas funções é social, e mesmo "ao se converterem em processos psíquicos permanecem quase sociais", pois ainda que ocorram no "homem isolado, consigo mesmo, conservam funções de comunicação", isto é, o caráter social dos processos psíquicos é conservado pelo modo de mediação estabelecido entre o individuo e a realidade. Mesmo sozinho, não se está plenamente isolado, pois mediadores semióticos, como pensamentos, e lembranças, intermedeiam as relações entre o pensamento humano e o meio em que se vive e se socializa (Vigotski, 2000, p. 151; Vigotski 2009a; Werstch \& Smolka, 2003; Werstch, 1999).

Contudo, Vigotski deixa claro que toda função psicológica superior apoia-se sobre uma base material e biológica, sem a qual ela não se internalizaria. Dialeticamente, o contrário também é verdadeiro, pois esse processo de transição de uma função inferior ou elementar para uma função superior não prescinde do convívio social. Isto é, uma criança não 
aprenderia a falar sem contato com a cultura humana, ainda que ela nascesse com toda a estrutura anatômica e neurológica, responsável pela fala, em perfeito estado biológico e fisiológico. Como já falamos, e aqui reafirmamos, apenas na relação com o outro, pela internalização ou "conversão das relações sociais em funções mentais" (Smolka, 2009, p. 8), tão somente por esta via, as funções psicológicas superiores, como memória lógica, atenção arbitrária, fala, percepção, imaginação científica, pensamento teórico, e outras, se desenvolvem; tão somente por esta via nos tornamos humano. Em síntese, as funções psicológicas superiores compreendem o sistema de funções mentais que nos elevam à condição de homo sapiens, nos diferenciando de qualquer outra espécie animal.

O processo de internalização ou de conversão ou, ainda, de apropriação das funções sociais em funções psíquicas, como sugere Smolka (2009), tem como via explicativa o processo de mediação, em que um elemento intermedeia a atividade humana, "como algo que intervém na consciência humana" (Teixeira, 2005, p. 99).

Os signos e os instrumentos são esses elementos intermediários. Signos e instrumentos têm em comum a função mediadora, embora se diferenciem em sua natureza, psicológica e física, respectivamente. Diferenciam-se por sua orientação: o signo, com orientação interna, atua no campo psicológico para controle do comportamento, como dispositivo para dominar processos mentais, sem modificar em nada o objeto de sua operação; e o instrumento, com orientação externa, não apenas conduz a ação sobre o objeto da atividade, como promove mudanças nesse objeto; a atividade mediada pelo instrumento é dirigida para o domínio e controle da natureza (Vigotski, 2010).

Embora distintos, signo e instrumento, são ligados entre si, uma vez que o controle do comportamento e da mente e o controle da natureza "estão mutuamente ligados, assim como a alteração provocada pelo homem sobre a natureza altera a própria natureza humana" (Vigotski, 2010, p. 55). O uso combinado de instrumentos e signos em atividades mediadas é intrínseco ao curso da história humana e, concomitantemente, à formação das funções psicológicas oriundas da conversão de processos simples externos (sociais) em processos complexos a nível interno da consciência e da personalidade.

$\mathrm{Na}$ atividade docente, como em qualquer atividade mediada, o uso de signos pode ser análogo ao uso de instrumentos ou emprego de ferramentas. A linguagem, que mediatiza o processo de comunicação em sala de aula, acumula, analogamente e indissociavelmente, as funções de signo e de instrumento, com orientações combinadas entre si tanto no plano 
externo como no plano interno. Ao mediatizar a comunicação, a linguagem é realizada como signo; e como instrumento, ao intermediar a ação do professor junto ao estudante.

Desse modo, supomos que o desenvolvimento das funções psicológicas superiores do professor, condizente com o seu desenvolvimento profissional, decorre do caráter social e mediado da atividade docente, diversificada pela variedade de signos/instrumentos usados como modos de mediação pelo professor. A mediação docente, como unidade que simboliza a relação aprendizagem e desenvolvimento é, exatamente, o que buscamos apreender para que possamos nos colocar no caminho do problema que orienta esta pesquisa.

A relação aprendizagem e desenvolvimento ocupa posição importante nos estudos de Vigotski, ao teorizar o desenvolvimento das funções psicológicas superiores ou o desenvolvimento humano. Suas fundamentações contrapõem a três teorias. A primeira justifica o desenvolvimento como "um processo de maturação sujeito às leis naturais" sendo a aprendizagem caudatária ou dependente do desenvolvimento - primeiro desenvolve, depois aprende (Vigotski, 2009b, p. 296). Isto é, para que a aprendizagem seja viável, o desenvolvimento deve completar determinados ciclos e concluir certos estágios.

No pensamento vigotskiano essa relação difere substancialmente, pois o aprendizado está apoiado sobre funções imaturas, e não sobre ciclos completamente desenvolvidos. A aprendizagem posiciona-se temporalmente à frente do desenvolvimento, o impulsionando e o desencadeando. O processo de aprendizagem da escrita, por exemplo, promove o desenvolvimento das funções vinculadas à escrita, uma vez que "até o momento de iniciar-se o estudo da escrita, todas as funções psíquicas básicas em que ela se assenta não concluíram ou sequer iniciaram o verdadeiro processo de seu desenvolvimento" (idem, p. 318). Esse resultado foi confirmado em investigações sobre o aprendizado da aritmética, da gramática e das ciências naturais, cujas respectivas funções psíquicas se mostraram imaturas no momento em que se inicia o aprendizado.

Chamamos a atenção para a ponderação expressa pela ideia de imaturidade das funções psíquicas, o que significa dizer que se deve considerar a existência de um limiar necessário na abrangência de determinados ciclos de desenvolvimento para que a aprendizagem se torne possível. Entretanto, Vigotski enfatiza que tal dependência não pode ser tomada nem como principal e nem como integral, mas como subordinada. Não há dúvida de que não é possível ensinar a linguagem escrita a uma criança de dois anos, pois certo limiar de desenvolvimento do pensamento, da memória e da atenção se torna necessário para que se 
possa enveredar por operações tão complexas como àquelas que compõem a ação de escrever. A tese de que a aprendizagem promove o desenvolvimento é reiterativa nesse corpo teórico.

A segunda teoria afirma que aprendizagem e desenvolvimento são processos idênticos e fundidos, temporalmente coincidentes. Na avaliação de Vigotski, essa premissa interrompe o debate, pois se aprendizagem e desenvolvimento são a mesma coisa, fica eliminada qualquer possibilidade de relação entre um e outro processo. Aprendizado e desenvolvimento não são processos nem paralelos e nem justapostos, mas ao contrário, são discrepantes entre si, os quais ocorrem sob ritmos diferentes - determinado aprendizado não só não acontece ao mesmo tempo que o desenvolvimento das funções correspondentes, como o desenvolvimento depende do aprendizado para de fato acontecer.

(...) aprendizado não é desenvolvimento; entretanto o aprendizado adequadamente organizado resulta em desenvolvimento mental e põe em movimento vários processos de desenvolvimento que, de outra forma, seriam impossíveis de acontecer. Assim, o aprendizado é um aspecto necessário e universal do processo de desenvolvimento das funções psicológicas culturalmente organizadas e especificamente humanas (Vigotski, 2010, p. 103).

A terceira teoria, embora mantenha conjunta as duas posições anteriores, avança por conceber possíveis efeitos da aprendizagem sobre o desenvolvimento. A aprendizagem, além de poder ir atrás do desenvolvimento, pode ser paralela a ele, como pode também superá-lo. Segundo Vigotski, apesar do caráter eclético e confuso dessa teoria, ela supera as anteriores por não desvincular aprendizagem e desenvolvimento e nem torná-los um único processo, tal qual a primeira e a segunda teoria, respectivamente. O elemento de avanço, coincidente com os pressupostos vigotskianos, é a possibilidade de mudanças no desenvolvimento promovida pela aprendizagem.

Todavia, Vigotski chama a atenção para o fato de que a relação entre aprendizagem e desenvolvimento não é direta e nem há plena correspondência entre um processo e outro. Ainda que se reconheça a relevância do ensino ou do aprendizado escolar na produção de situações de aprendizagem com potenciais significativos na promoção de diferentes níveis de desenvolvimento, não é possível mensurar e nem demonstrar quantos passos no desenvolvimento cada aula de aritmética pode provocar, por exemplo. Como afirma Vigotski (2009b, p. 322), “o desenvolvimento não se subordina ao programa escolar, tem sua própria lógica". 
Há clareza de que processos de aprendizagem organizados pelo ensino ou em contextos extraescolar configuram-se no plano das relações interpessoais, portanto com potenciais para serem convertidos ou trasladados para o plano interno ou intrapessoal característico do desenvolvimento psíquico ou da formação das funções psicológicas superiores. A relação aprendizagem e desenvolvimento, explicitada por Vigotski, guarda coerência com a lei presente em sua teoria geral, a qual preconiza a ideia de que todo e qualquer desenvolvimento segue o curso do social para o individual, em que situações sociais são convertidas em situações mentais.

Essa lei torna-se princípio orientador e explicativo do método adotado por esse pensador para definir o estado de desenvolvimento de um sujeito, discutido em referência a dois níveis: o real, composto pelas funções já amadurecidas, definidas pela resolução autônoma de problemas; e o potencial, contemplado pelas funções mentais em processo de maturação.

Para o estudo do curso do desenvolvimento psíquico, Vigotski considera o nível de desenvolvimento potencial como mais importante, pois as funções maduras, próprias do nível de desenvolvimento real, não mostram a totalidade do estado de desenvolvimento. Interessalhe substancialmente o resultado da relação que pode ser estabelecida entre esses dois níveis, entre o que o sujeito já sabe e o que ele poderia conseguir fazer em cooperação com companheiros mais capazes; ou seja, entre as funções maduras e as funções em processo de maturação. Essa discrepância entre a idade mental real e o nível potencial atingido ao se resolver problema com a ajuda do outro, é denominado de Zona de Desenvolvimento Proximal (ZDP).

Zona de Desenvolvimento Proximal tornou-se um conceito de extrema importância para investigações que tenham como objetivo o estudo de processos de aprendizagem e de desenvolvimento, uma vez que a dinâmica de desenvolvimento intelectual de um sujeito pode ser discutida com base no campo de possibilidades característico de sua zona.

A fluidez e a mutabilidade das funções em formação contidas na ZDP explicam o fenômeno de conversão da aprendizagem em desenvolvimento: as funções imaturas possuem a potencialidade de se converterem e se tornarem funções mentais internalizadas. Por conseguinte, é possível delimitar que o que compõe a Zona de Desenvolvimento Proximal hoje, poderá compor o nível de desenvolvimento real amanhã, ou seja, o que um sujeito consegue fazer hoje em colaboração, no âmbito das relações interpessoais condizentes com o seu processo de aprendizagem, será capaz de fazer sozinho amanhã, posto que processos de 
aprendizagem, composto por funções em processo de amadurecimento, terão se convertido e se internalizado. Isto significa dizer que a aprendizagem está para o desenvolvimento assim como a ZDP está para nível de desenvolvimento atual ou real.

A Zona de Desenvolvimento Proximal é considerada como um período sensível à aprendizagem ou período optimal de aprendizagem. O conceito de período sensível foi tomado de empréstimo da Biologia por Vigotski e definido por Friedrich (2012, p. 110), como “(...) um lapso de tempo bem específico durante o qual o organismo é particularmente sensível às influências do meio. Durante esse período, o meio orienta e determina fortemente o curso do seu desenvolvimento e provoca grandes modificações".

Por suposto, em relação ao desenvolvimento profissional docente, presumimos a ideia de que a inter-relação aprendizagem e desenvolvimento na docência regula o desenvolvimento das funções psicológicas superiores dos professores, o que nos leva a dimensionar o desenvolvimento profissional docente como um processo de contínua conversão e internalização das funções relacionadas à atividade laboral. Logo, as situações colaborativas e formativas que movimentam as esferas teórico/prática da atividade docente podem ser entendidas como elementos de aprendizagem que, por adiantarem ao desenvolvimento, podem incidir sobre a Zona de Desenvolvimento Proximal do professor, e como tal, serem capazes de promover seu desenvolvimento profissional.

A Zona de Desenvolvimento Proximal do professor, fortemente e continuamente influenciada e modificada por diferenciadas possibilidades de mudanças, resultantes de diferentes situações de aprendizagem inerentes à docência, aparenta-se como um "lapso de tempo" ou como "um período sensível”, tal qual define Friedrich (2012) e Vigotski (2009b).

O esquema seguinte, tomado de empréstimo da pesquisadora Araújo (2003, p.22), no qual fazemos pouquíssimos acréscimos, propicia uma síntese da discussão em pauta, direcionada para a relação aprendizagem e desenvolvimento no processo formativo docente. O valor deste esquema está na possibilidade de visualização da totalidade do movimento contínuo frequente na ZDP, entendida como um campo de mediações, portanto de relações interpessoais, rico em processos de aprendizagem, com potenciais de conversão em processos de desenvolvimento. 


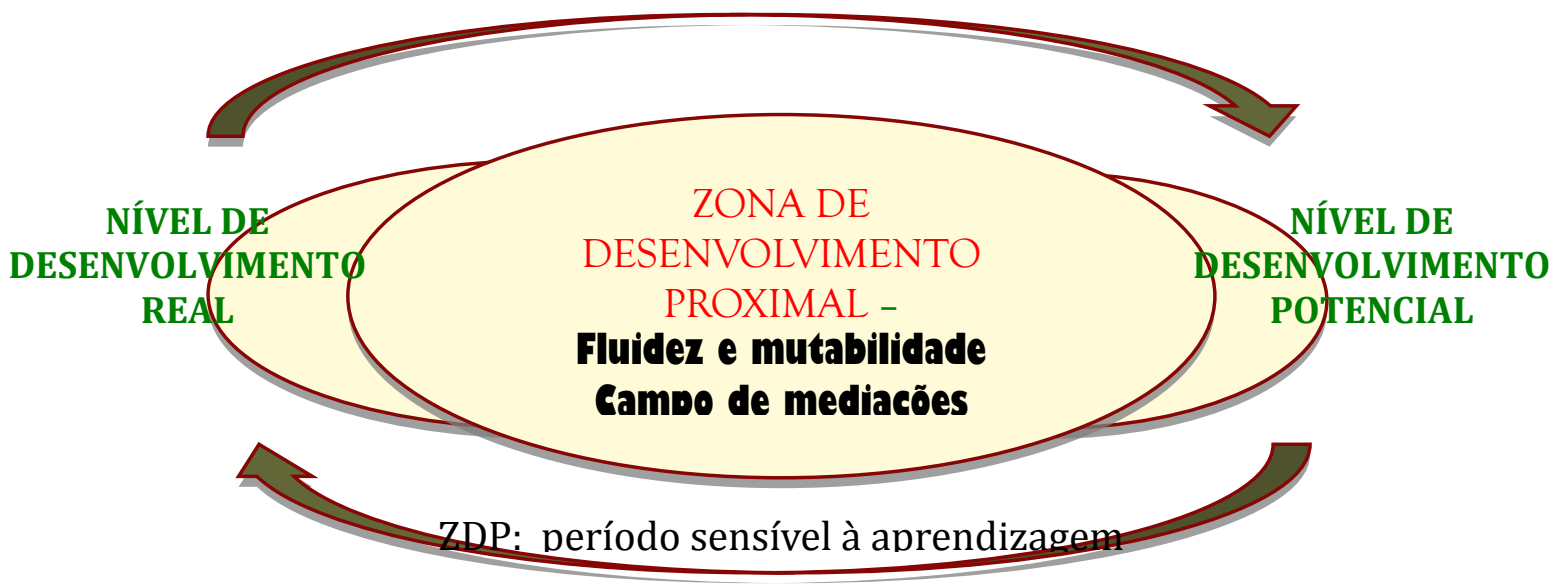

VIDA PROFISSIONAL

Figura 03 - Relação aprendizagem docente e desenvolvimento profissional.

A ZDP do professor, entendida como um período sensível às situações de aprendizagem da docência, reserva as relações interpessoais condizentes com trabalhos coletivos realizados com parceiros de trabalho ou com formadores nos diferentes processos formativos e com o movimento dialógico diário estabelecido com seus alunos. Cada professor tem a sua ZDP com suas peculiaridades, suscetíveis a mudanças contínuas nas funções em processo de maturação que a compõe. Por isso falarmos no caráter mutável e fluído dessa zona.

Reiteramos a ideia de conversão da aprendizagem em desenvolvimento, a qual ocorre em função da incidência de situações de aprendizagem sobre a ZDP resultantes de relações entre pessoas que resolvem problemas em cooperação. É fácil imaginar essa relação entre professores parceiros e entre professores e formadores e coordenadores, em que se presencia a cooperação e a ajuda mútua, com destaque para a relação com a presença de um companheiro mais capaz, quem, supostamente, colabora com a resolução de problemas de ensino com conteúdos não alcançáveis apenas pelo grupo de professores.

Chamamos a atenção para o campo de possibilidades que se forma na relação estabelecida entre professor e alunos em sala de aula. Tal como em uma comunidade de aprendizagem, a sala de aula é um "contexto em que múltiplas zonas de desenvolvimento proximal ocorrem ao mesmo tempo" (Daniels, 2003, p. 156). Em tal cenário, as ZDPs do professor e dos tantos alunos se sobrepõem em cooperação. Entretanto, em relação à aprendizagem e desenvolvimento do professor em tal contexto, indagamos: como o professor resolve situações difíceis ou espinhosas em sala de aula junto aos seus alunos, sendo esses, 
supostamente, menos capazes e menos experientes? Quem são os companheiros mais experientes que colaboram com o professor na solução de tais situações e, por conseguinte, contribuem para sua aprendizagem e desenvolvimento profissional?

$\mathrm{Na}$ verdade, este questionamento situa-se na base do problema que orienta esta pesquisa, a qual será discutida mediante análise dos dados. Entretanto, adiantamos esta discussão com a ideia da Zona de Desenvolvimento Proximal como um campo de mediações e de múltiplos apoios, no qual participam muitas vozes para além daquelas que se fazem presentes fisicamente. Nos limites de nosso conhecimento sobre a obra de Vigotski, não encontramos a afirmação de que o companheiro mais capaz ou mais experiente deve está sempre presente fisicamente. Ao contrário, encontramos fundamentos para anunciar a solução de problemas em colaboração, sem que o sujeito aprendiz conte necessariamente com a presença física de seu colaborador. Vamos ouvir o próprio Vigotski:

Quando em casa a criança resolve um problema com base num modelo que
lhe mostraram na sala de aula, ela continua a agir em colaboração, embora
no momento o professor não esteja ao seu lado. De uma perspectiva
psicológica, a solução do segundo problema é similar a essa solução de um
problema em casa. É uma solução alcançada com a ajuda do professor. Essa
ajuda - esse aspecto da colaboração - está visivelmente presente. Está
contida no que parece, de fora, a solução independente dada ao problema
pela criança (Vygotsky, 1987, p. 216).

Provavelmente, Vigotski considera o que ele próprio denominou de "voz social interior", interpretado por Clark (1998) como a condução de um diálogo consigo mesmo. Segundo Clark (1998), uma criança, diante de algum problema que tenha que resolver na ausência de seu professor ou de outro adulto, terá sua ação mediada por lembranças de orientações recebidas anteriormente. Essas lembranças apareceriam na forma de vozes ouvidas e interpretadas pela criança e aplicadas à solução do problema.

É possível transpor essa discussão para a situação do professor diante de um problema de ensino, sem a presença física de companheiros mais experientes, o qual é resolvido com a ajuda de vozes interiores trazidas à memória, advindas de experiências anteriores ou de suas vivências formativas e profissionais.

As múltiplas vozes na atividade docente podem ser entendidas, no âmbito da escola, como um sistema coletivo de atividade, na abrangência dos princípios atuais da Teoria da Atividade defendidos por Engestrom (1999) e Daniels (2003). Sob tais princípios, a escola assume a dimensão de uma comunidade de múltiplas vozes em inter-relação a outros sistemas 
de atividade igualmente multivocais. Essas tantas vozes ouvidas constituem a memória docente, inserida em uma rede de colaborações virtuais.

Dada à diversidade de situações vivenciáveis pelo professor na sala de aula, vale destacar duas considerações: a possibilidade de se sentir sozinho diante de uma situação espinhosa e não escutar nenhuma voz colaboradora; como é possível escutar mais de uma voz.

A respeito da segunda consideração, Daniels levanta um importante questionamento: se vozes virtuais apoiam a ZDP, então "certamente há um lugar para várias vozes numa ZDP particular" (2003, p. 88). Sendo assim, o que aconteceria no caso de se ouvir mais de uma voz discordantes entre si? No âmbito da memória, diferentes vozes podem proporcionar ao sujeito que as ouve diferentes maneiras para resolver determinado problema. Não é difícil imaginar tal situação, basta supor um professor que, diante de uma situação inesperada e espinhosa em sala de aula junto aos seus alunos, recorre às tantas vozes advindas de suas experiências formativas e práticas. Em caso de vozes divergentes, restaria a esse professor a escolha de uma delas, a tomada de decisões rápidas a fim de resolver a situação, e até de não resolvê-la, em caso de nenhuma das vozes serem suficientes. Nesse caso, o professor pode ficar à sorte de suas próprias experiências, lembranças e vozes interiores.

Embora, os alunos não sejam configurados como o companheiro mais experiente do professor, como tal, não se posicionando como colaboradores na resolução de problemas de ensino, não descartamos possibilidades de que eles venham a cumprir tal papel, seja por meio de perguntas e até mediante a introdução de elementos teóricos importantes para o movimento dialógico discursivo. Afinal, não desmerecemos o potencial das vozes dos alunos nas diferentes situações de aprendizagem que podem compor o cenário da sala de aula.

Em síntese, tomamos consciência da complexidade de se pensar o desenvolvimento profissional docente dentro da sala de aula ou a partir deste lugar. Necessário se faz relembrar a vinculação da ideia de desenvolvimento profissional à dimensão da construção do trabalho docente no sentido da práxis, ou seja, da superação da alienação, em que o professor, ao buscar transformar o seu objeto de trabalho, utilizando como instrumento a linguagem e seus conhecimentos, em inter-relação com a linguagem e o conhecimento do outro, transforma também a si próprio: a sua natureza humana e profissional é modificada e acrescida pelo processo de trabalho. 
Vale ressaltar que a sala de aula, embora seja considerado como o lugar por excelência do desenvolvimento profissional porque abriga as principais relações de trabalho entre o professor e aluno, conta com o importante apoio das diferentes ações da docência realizadas nos fóruns coletivos de discussões, estudos e planejamentos ocorridos dentro e fora da escola. As múltiplas vozes ressoadas do trabalho coletivo e da vida profissional e formativa podem se fazer virtualmente presentes e influenciar a contínua mediação do professor junto aos seus alunos.

Nessa compreensão, o conceito de desenvolvimento profissional docente é deslocado do campo individual, isto é, da atividade de um professor, para o sistema coletivo de atividade, em que diferentes vozes em inter-relação e diferentes qualidades de situações passam a influenciar as ZDPs dos sujeitos em atividade. A ZDP de cada sujeito envolvido ganha mais fluidez e mutabilidade, com mais suscetibilidade a diferenciadas qualidades de intervenções e incidências.

Com este corpo de ideias, passamos ao próximo capítulo, no qual aprofundamos o conceito de mediação, com destaque para a mediação docente via linguagem como signo/instrumento mediacional do processo de ensino e aprendizagem. 


\title{
Capítulo 2 - Trabalho docente: linguagem como signo/instrumento de mediação e de aprendizagem docente em aulas de ciências
}

\author{
"Quem não vê bem uma palavra, \\ não pode ver bem uma alma." \\ Fernando Pessoa
}

Neste capítulo, a atenção é dedicada à mediação e à linguagem. A discussão é iniciada pela conceituação de mediação, com a intenção de posicionar esse conceito como princípio base das relações inerentes aos processos de aprendizagem e desenvolvimento. Em seguida, a linguagem é colocada em cena, abordada em duas dimensões: primeiro, num plano mais teórico com foco em sua gênese e conceituação, para em seguida, discutir a sua inserção e função no âmbito da atividade docente no ensino de ciências. Mediação e linguagem perfazem o eixo central deste trabalho, acrescidos neste capítulo por outros conceitos, como enunciação e dialogia. O que se pretende não é senão abrir caminhos para se chegar à essência do complexo fenômeno em estudo - a relação entre o ensinar e o desenvolvimento profissional docente.

\subsection{Mediação: conceito explicativo do desenvolvimento humano}

Mais que um conceito, a categoria mediação, oriunda do pensamento marxista, constitui a essência do pensamento marxista herdado e legado por Vigotski, o de que "o desenvolvimento dos processos psicológicos humanos surgem pela atividade prática, culturalmente mediada e de desenvolvimento histórico" (Cole, 1996, p. 108). A atividade mediada é vista como a gênese da formação cultural e histórica humana, daí o conceito mediação se constituir como princípio explicativo da lei cara à teoria vigostskiana desenvolvimento das funções psicológicas superiores.

O postulado da mediação é, sem dúvida, um divisor de água no campo da Psicologia, pois ao derrubar "os muros cartesianos que isolam a mente do indivíduo de sua cultura e da sociedade" (Engestrom, 1999, p. 29), rompe com a visão naturalística e determinista, por fundamentar a formação humana a partir da conjunção biológica e social. Sem as relações sociais, por assim dizer mediadas, as funções elementares não se converteriam em funções 
intramentais; dito de outro modo, sem tais relações, as funções psicológicas, como a memória, por exemplo, não extrapolariam o limite da maturação biológica (Vigostki, 2010).

A mediação explica e justifica a interligação do homem ao mundo em que vive; a interligação das pessoas entre si nas diferentes relações que marcam a produção do mundo humano. Sem mediação não haveria atividade humana, isto é, não haveria trabalho, nem educação, enfim, não haveria comunicação e, por conseguinte, não haveria aprendizagem e desenvolvimento humano.

Como o próprio termo já sugere, mediar é se colocar entre; e de fato, não há mediação sem os elementos que se interpõem nas ações mediadas, entre o homem e o seu objeto de trabalho ou entre a criança e o seu brinquedo, ou ainda entre o estudante e o seu objeto de aprendizagem, ou mesmo entre duas pessoas ao realizarem qualquer tipo de ação conjunta. Ferramentas psicológicas ou signos de orientação interna, e/ou instrumentos com orientação externa, intermedeiam essas relações. Vale lembrar que signos e instrumentos têm funções análogas, se diferenciando basicamente nas maneiras pelas quais eles orientam o comportamento humano. Portanto, signo e instrumento podem estar incluídos dentro do conceito geral de atividade mediada, com difícil distinção entre um e outro em variadas ações. Podem estar inclusos no conceito de modos de mediação, usado com frequência neste trabalho, ou no conceito de ferramenta cultural adotado por Werstch (1999).

Segundo Vigotski (2010, p. 33) a ação operada com signos, portanto mediada,

[...] requer um elo intermediário entre o estímulo e a resposta. Esse elo intermediário é um estímulo de segunda ordem (signo), colocado no interior da operação, em que preenche uma função especial; ele cria uma nova relação entre S (estímulo) e R (resposta). O termo "colocado" indica que o individuo deve estar ativamente engajado no estabelecimento desse elo. Esse signo possui, também, a característica importante de ação reversa (isto é, ele age sobre o indivíduo e não sobre o ambiente).

Além da caracterização de uma ação mediada, o texto de Vigotski informa um aspecto importante da mediação - o caráter ativo do sujeito. É o sujeito quem coloca o signo ou o instrumento no interior da ação - a palavra, como signo, o lápis ou a faca como instrumentos, são elos intermediários introduzidos na relação pelo sujeito em atividade, interpostos entre ele e objeto em transformação. Essa característica delega à mediação, o caráter de controle do sujeito sobre as relações estabelecidas. 
Werstch (1999) valoriza os pressupostos vigotskianos, ao teorizar sobre a ação mediada. Na complexidade de uma ação mediada, esse autor chama a atenção para os papéis desempenhados pelo sujeito e pelos modos de mediação. Ambos, sujeito e elo mediador, impõem elementos diferenciais de cunho social e cultural à ação e aos seus resultados. Sem os modos de mediação, não há como o sujeito atuar; e sem a ação do sujeito, nenhum objeto se transforma, por conseguinte, nenhum fenômeno ocorre. Com tais premissas, Werstch fundamenta a existência de uma tensão irredutível entre o sujeito e o modo de mediação na ação mediada; integrados, um não existe sem outro, constituindo-se uma unidade indecomponível. Essa integração é vista na interdependência do sujeito em relação ao signo ou ferramenta cultural, usado por ele para resolver um problema matemático, tal como exemplifica Werstch: “(...) para a pergunta de quem resolveu o problema, a resposta mais adequada seria, por exemplo: ‘eu e a ferramenta cultural que utilizei’” (Werstch, 1999, p. 57).

Embora enfatize a relação de dependência que há entre o sujeito e a ferramenta cultural no processo de realização de ações, Werstch não diminui a autonomia do sujeito, delegada por Vigotski, para a escolha de sua ferramenta e controle sobre a ação. Apesar de indecomponível e irredutível, a unidade agente/modo de mediação delega ao sujeito o domínio sobre o processo de ação. Todavia, Werstch destaca a influência do modo de mediação sobre a dinâmica da ação mediada, ao afirmar que o surgimento de novas ferramentas culturais pode transformar as relações de poder e de autoridade envolvidas em uma ação.

É lógico que apenas o reconhecimento do surgimento e da importância de uma ferramenta cultural não determina a sua adoção imediata pelo sujeito, e mesmo que ele viesse a adotá-la, não significaria mudança imediata na ação mediada e muito menos em sua permanência nessa ação. Tais mudanças dependem também da aceitação e adaptação do sujeito ou dos sujeitos envolvidos na relação, além de serem influenciadas por fatores de diferentes naturezas.

Para melhor compreensão, vamos pensar nas mudanças das ações docentes ocorridas por ocasião da introdução de um recurso à dinâmica de sala de aula. Vamos supor que uma professora resolva introduzir em suas aulas de ciências o uso do microscópio estereoscópio (lupa de mesa) com fins específicos direcionados para a visualização de fungos em um pão embolorado. Em tal situação, é possível imaginar mudanças tanto no plano das ações, como no plano organizacional e comportamental dos sujeitos envolvidos. A professora interpôs entre seu objetivo de ensino e a aprendizagem de seus alunos não apenas um instrumento material, mas diferentes qualidades de signos, como por exemplos, uma proposta 
metodológica de como ensinar ciências, a própria imagem da colônia dos fungos vistos a olho nu e ampliada pelo microscópio, conceitos relacionados ao conteúdo em estudo, entre outros.

A permanência desse novo instrumento e desses novos signos adotados, como modo de mediação por essa professora, depende de muitos fatores objetivos, mas, sobretudo de sua avaliação quanto aos resultados das ações, por sua vez relacionados à realização de seus motivos/objetivos intrínsecos à sua intenção de ensinar de modo que seus alunos aprendam. Essa permanência é vista por Werstch (1999) como um processo de apropriação do sujeito sobre o modo de mediação, por sua vez, condicionado pelo domínio sobre como usá-lo.

Domínio e apropriação são conceitos distintos. Domínio se refere ao saber como usar um modo de mediação, enquanto que a apropriação significa toma-lo para si e fazê-lo próprio. São processos que nem sempre estão entrelaçados, não havendo necessariamente uma relação direta ou de mão dupla entre eles. De acordo a Werstch, embora a apropriação requeira domínio, um sujeito pode saber usar determinado instrumento ou signo, isto é, dominá-lo, sem, no entanto se apropriar dele. Uma professora, por exemplo, pode dominar determinado método de ensino, porém sem adotá-lo com permanência em suas aulas. Ao usá-lo, poderia fazê-lo em uma situação de conflito ou resistência. Entretanto, segundo esse mesmo autor (1999, p. 97),

\footnotetext{
Quando esse conflito ou resistência torna-se forte o suficiente, o agente pode recusar-se completamente a usar essa ferramenta cultural. Em tais casos, podemos dizer que esses agentes não consideram que essa ferramenta cultural lhes pertença. Se ainda assim esses agentes se veem forçados a usar esse modo de mediação, seu desempenho pode se caracterizar por formas claras de resistência, como a simulação.
}

A não permanência de determinado modo de mediação ou o seu uso em caráter de simulação, exemplificaria uma situação de não apropriação da ferramenta pelo sujeito. Apoiando-nos na Teoria da Atividade, poderíamos dizer que essa não apropriação seria uma situação em que o sujeito estaria agindo mobilizado por um motivo que não lhe pertence verdadeiramente, isto é, por um motivo dito compreensível. Em tal situação, o modo de mediação simulado integraria ações correlatas ao objetivo de outra atividade, na qual ele não estaria de fato inserido.

Reiteramos a ideia de Wertsch, a de que a permanência de determinado modo de mediação nas ações do sujeito, está intrinsecamente ligada à apropriação do sujeito sobre esse modo de mediação, ou seja, ao sentimento de que tal ferramenta cultural de fato lhe pertença. 
Associamos tal ideia ao pressuposto intrínseco à Teoria da Atividade, a de que a apropriação de determinado modo de mediação tem tudo a ver com as correlações existentes entre as ações integradas a esse modo de mediação, o motivo do sujeito que a realiza e o objeto da atividade.

Retornando ao texto de Vigotski (2010), vale destacar como importante a ideia exposta sobre o caráter de ação reversa dos meios mediacionais. Aqui se encontra a chave para melhor compreender por que ao se operar com signos se cria a possibilidade de autotransformação qualitativa do comportamento do sujeito. A resposta está no fato de que a função de ação reversa do signo "confere à operação psicológica, formas qualitativamente novas e superiores, permitindo aos seres humanos (...) controlar seu próprio comportamento" (idem, p. 34). É exatamente o uso de signos que demarca o limite diferencial entre o Homo sapiens e as demais espécies de animais, por conduzir "os seres humanos a uma estrutura específica de comportamento que se destaca do desenvolvimento biológico e cria novas formas de processos psicológicos enraizados na cultura” (ibidem, p. 34). Processos elementares e processos psicológicos superiores se diferem quanto à origem, biológica e sociocultural, respectivamente, e seguem linhas de desenvolvimento qualitativamente diferentes.

Para Vigotski, a história natural da operação com signo/instrumento coincide com a própria história do comportamento e desenvolvimento da criança. As operações iniciais realizadas pelo bebê são diretas ou não mediadas, as quais vão se tornando mediadas após uma série de transformações qualitativas. Claro, nem todas se transformam, pois mesmo na fase adulta algumas ações podem ser diretas. Esse processo de transformação das operações é prolongado e de alto grau de complexidade, desencadeado pelas próprias condições de vida e de experiência da criança e pela evolução dos meios mediacionais. Uma ação operada com signo gera condições qualitativamente diferentes para uma nova operação, e assim sucessivamente. Uma ação condiciona outra ação, a qual é também condicionada pela precedente.

Wertsch (1999) colabora com o entendimento de que não é apenas o sujeito que se desenvolve, mas a ação mediada, a qual conta com a evolução conjunta de seus componentes. O papel do trabalho no desenvolvimento do homem e na produção do mundo humano é um bom exemplo de atividade mediada ilustrativa dessa evolução. As necessidades humanas dão o tom da evolução histórica do instrumento, gerando cada vez mais instrumentos cada vez mais eficazes do ponto de vista da temporalidade e qualidade da produção, os quais, por sua 
vez, em sua ação reversa, promovem mais transformações qualitativas no quadro psicológico do sujeito em ação. Desse modo, reafirmamos a ideia inicial da mediação ou ação indireta, como o elo propulsor das relações sociais e culturais inerentes ao curso geral do desenvolvimento humano e, mais especificamente, a não linearidade dos processos psicológicos relacionados à apropriação de significados.

A aprendizagem ou apropriação de significados pela criança no âmbito da escolaridade não prescinde em nenhum instante da atividade mediada ou da operação com signos e com instrumentos. A aprendizagem não pode ser explicada, senão como um processo resultante de um conjunto de ações mediadas, com grande variedade de elos intermediadores, ora o outro (professor e colegas), ora material (livros, cadernos, e tantos outros dessa natureza), ora elementos psicológicos (palavra, lembranças, conhecimentos, pensamentos). Seja signo ou instrumento, esses elementos se fundem nas funções desempenhadas pela linguagem: planejamento, análise, síntese, em suma, comunicação. Não há dúvida, a linguagem, em qualquer fase do desenvolvimento humano, é o instrumento/signo que reúne infinidades de funções semióticas.

O papel do professor também não prescinde da operação com signos para objetivar o seu motivo/sentido na significação social de sua profissão. Vale perguntar: é possível pensar na atuação docente, senão como um conjunto de ações mediadas? É possível pensar no desenvolvimento profissional docente, senão como resultados de situações de aprendizagem regidas por ações mediadas? O professor, ao mesmo tempo em que realiza ações mediadas se constitui como elo mediador, se interpondo entre seus alunos e o significado em apropriação. O professor incorpora um conjunto de instrumentos e signos intermediadores coadunados na linguagem, por sua vez, síntese e tradução das ações e pensamentos docentes. Mais uma vez, a linguagem é eleita como a principal ferramenta cultural.

A linguagem é, portanto, o foco principal da discussão que se segue.

\subsection{Linguagem e palavra: gênese, conceito e função social}

Na teoria histórico-cultural, a linguagem é um conceito chave, concebida como o grande elo de mediação e de comunicação produzido e desenvolvido simultaneamente ao desenvolvimento histórico e cultural da humanidade. Ao mesmo tempo em que a linguagem, como modo de mediatização da comunicação, propicia o avanço do processo de 
desenvolvimento humano, esse processo, ao avançar, possibilita refinamento e qualificação da linguagem.

Na verdade, a linguagem é tão antiga quanto o primeiro ato mediado do Homo sapiens realizado em inter-relação social com outro Homo sapiens. Como bem afirmou Bakhtin (2010), para aparecer a linguagem não bastou que dois indivíduos da espécie humana se juntassem, pois o seu aparecimento somente ocorre em terrenos em que indivíduos humanos estejam organizados socialmente. A linguagem nasce nas e das relações entre homens; nasce no e do processo de trabalho socialmente dividido; nasce da necessidade sentida pelos homens de se comunicarem, de dizerem alguma coisa um ao outro (Leontiev, 1978; Luria, 2001). Apenas sob tais condições se torna possível a constituição da linguagem como um sistema de signos (Bakhtin, 2010).

Em sua gênese, a linguagem esteve estreitamente ligada a gestos, a sons inarticulados, cujos significados dependiam da situação prática, das ações e suas relações. Aliás, em seu estágio inicial a linguagem era fundida à prática, separando-se desta posteriormente, "ao se transformar num sistema de códigos sintáticos complexos" (...), "suficiente por si próprio para formular qualquer relação abstrata, qualquer ideia”, bem como para transmitir qualquer informação (Luria, 2001, p. 22-23).

Para esse autor, a linguagem humana, diferentemente da "linguagem natural" do animal, “designa objetos, características, ações ou relações” (idem, p. 25); os animais apenas expressam um estado ou vivência com o qual contagia outros animais, não se efetivando como uma linguagem em seu sentido completo, e sim como uma "quase linguagem". Eis porque Vigotski (2009b) afirma que entre os animais, mesmo entre os antropoides, a comunicação não é mediatizada pela linguagem, daí nem sequer merecer ser chamada de comunicação.

Segundo Luria (2001), a aparição da linguagem humana foi o fator determinante para que o homem passasse da conduta animal à atividade consciente. Marx e Engels afirmaram que a linguagem é tão antiga quanto a consciência, nascem juntas e são inseparáveis:

A linguagem é tão antiga como a consciência, a linguagem é a consciência real, prática, que existe também para outros homens, que, portanto, também existe para mim mesmo; a linguagem nasce, tal como a consciência, do carecimento, da necessidade de intercâmbio com outros homens. Desde o inicio, portanto, a consciência, já é um produto social e continuará sendo enquanto existirem homens (Marx \& Engels, 2007, p. 34-35). 
Este posicionamento sobre a origem da linguagem e da consciência humana marca o pensamento marxista, o qual baliza diferentes estudos desde tempos remotos até a atualidade. Contrária aos pressupostos da psicologia tradicional, para a qual a consciência humana se origina das profundidades da alma e de mecanismos cerebrais, a teoria oriunda das teses marxistas explica a formação da consciência, tal qual já explicitamos em passagens anteriores, "na relação do homem com a realidade, em sua história social, estreitamente ligada com o trabalho e a linguagem" (Luria, 2001, p. 23). Em suma, linguagem e consciência são produtos da atividade humana, das relações humanas estabelecidas em coletividade.

Estamos nos referindo à formação da linguagem na filogênese, à pré-história da linguagem na espécie humana, a qual não se repete na ontogênese, ou seja, no desenvolvimento do indivíduo dessa espécie. A criança não aprende a se comunicar nas relações de trabalho, e sim na relação com o adulto e demais pessoas com as quais convive. Entretanto, ainda que a formação da linguagem no âmbito da ontogênese se diferencie de sua formação filogenética, resulta também na elaboração de um sistema de códigos em que a palavra é o seu elemento por excelência. Em relação à formação desse sistema de códigos e à formação da palavra, Luria (2001) chama a atenção para o fato de que os primeiros sons emitidos pela criança são apenas estados e não se desenvolvem ao grau da linguagem, pois as primeiras palavras não nascem desses sons, mas sim daqueles oriundos da fala dos adultos, por sua vez ouvidos e assimilados pelas crianças.

A aparição da palavra é relacionada a esse processo histórico e completamente vinculada a ele, seja na ontogênese, seja na filogênese. A palavra, como "célula da linguagem", como seu "elemento fundamental e central" cumpre o papel de conter a generalização "como modo absolutamente original de representação da realidade na consciência" (Vigotski, 2009b, p. 407; Luria, 2001).

Em confluência com a perspectiva teórica referenciada, Bakhtin (2010) diz que a palavra surge exatamente da necessidade de materialização da comunicação, se constituindo como um "signo ideológico". A palavra, exatamente por carregar essa função semiótica, abriga a consciência, a qual tem em comum com a palavra, "a lógica da comunicação ideológica, da interação semiótica de um grupo social” (idem, p. 36).

Sobre esse papel da palavra, Bakhtin (2010, p. 36) enfatiza:

A palavra é o fenômeno ideológico por excelência. A realidade toda da palavra é absorvida por sua função de signo. A palavra não comporta nada que não esteja ligada a essa função, nada que não seja gerado por ela. A 
palavra é o modo mais puro e sensível de relação social (itálico no texto original).

Todavia devemos lembrar-nos do quão fluído e mutável é o terreno da palavra, uma vez que em seu papel de signo pode expressar qualquer consciência individual; pode representar qualquer sentido ou preencher qualquer função ideológica. A mesma palavra pode mediar conversações com pontos de vistas diferenciados e até contraditórios. Como instrumento da consciência, a palavra "acompanha toda criação ideológica, seja ela qual for. A palavra acompanha e comenta todo ato ideológico" (Bakhtin, 2010, p. 38 - itálico no texto original).

Vigotski, em sintonia com Bakhtin, nos fala da relação palavra/consciência:
A consciência se reflete na palavra como o sol em uma gota de água. A palavra está para a consciência como o pequeno mundo está para o grande mundo, como a célula viva está para o organismo, como o átomo está para o cosmo. Ela é o pequeno mundo da consciência. A palavra consciente é o microcosmo da consciência humana (Vigotski, 2009b, p. 486).

Vigotski reforça o papel da palavra como abrigo da consciência, a qual pode ser expressa não apenas por meio da fala, mas pela ação, escrita, gestos e, muitas vezes, por meio do silêncio, pois, em determinadas situações, a ausência física da palavra fala por si por conter palavras ocultas, nas quais subsistem pensamentos que se materializam no processo de comunicação. Enfim, a palavra em seus diferentes modos de expressão se constitui como signo ideológico por revelar nossos sentidos, isto é, o que somos e o que pretendemos nas e das relações humanas das quais fazemos parte - é a palavra que revela como o quadro do mundo se apresenta para cada um de nós: ela é o signo/instrumento mediador das relações constitutivas da atividade, sob o qual se mostra a consciência, identidade e personalidade humana.

Em continuidade a essa discussão contamos com Vigotski para aprofundar a relação entre o pensamento e a palavra. Para esse autor, a palavra é a substância material do pensamento, pois ao falarmos não estamos simplesmente exprimindo determinado pensamento, mas realizando-o. A linguagem não serve para exprimir um pensamento pronto e acabado, e nem linguagem e pensamento são a mesma coisa, como também não são funções independentes entre si. A relação entre pensamento e palavra se revela por meio de movimentos que perpassam planos internos e externos, intramentais e intermentais: o pensamento engendrado no campo da consciência passa por reestruturações e modificações 
no plano interno e, pouco a pouco, toma a forma da linguagem exterior, consubstanciada em palavras. A palavra, portanto, em sua função semiótica, tanto advém do pensamento como o alimenta; tanto revela o conteúdo da consciência como o compõe.

Para Bakhtin (2010) e Vigotski (2009b) pensamento e palavra se encontram no significado da palavra, ou melhor, na palavra com significado. Sem o seu significado, a palavra se reduziria a um som vazio, à sua realidade física, não mais pertencente ao reino do pensamento e nem ao reino da linguagem. Vigotski (2009b) elege o significado da palavra como a unidade do pensamento verbalizado, ou seja, como unidade da comunicação. Somente sob tal complexidade, a palavra realiza a sua função de signo no processo de comunicação e de transmissão de ideias e vivências.

$\mathrm{Na}$ realidade, o que pronunciamos e escutamos não são palavras com sons vazios, mas significados das palavras: pronunciamos e escutamos o conteúdo ou sentido ideológico ou vivencial da palavra - "verdades ou mentiras, coisas boas ou más, importantes ou triviais, agradáveis ou desagradáveis, etc.” (Bakhtin, 2010, p. 98-99).

$\mathrm{O}$ ato da fala revela-se no processo de comunicação como um ato de natureza eminentemente social produzido nas interações verbais. $\mathrm{O}$ ato da fala, assim concebido, é denominado por Bakhtin de enunciação. A enunciação é, por conseguinte, esse produto vivo que advém das forças sociais de locutores e ouvintes em inter-relação. Nessa perspectiva, o falante sempre invoca uma linguagem social ao produzir uma enunciação, e essa linguagem social configura o que a voz individual do falante quer dizer (Werstch e Smolka, 2003). Colaço et al (2007) inspiram-se em Bakhtin para afirmar que a linguagem é um "processo enunciativo, dialógico e constitutivo de subjetividade".

Nem seria preciso dizer que a palavra é o signo que medeia a conversação, ora pronunciada pelo locutor, ora pelo interlocutor; sempre apresentando suas duas faces, pois ora procede de alguém, ora se dirige para alguém. Nas próprias palavras de Bakhtin (2010, p, 117):

Toda palavra serve de expressão a um em relação ao outro. Através da palavra defino-me em relação ao outro, isto é, em última análise, em relação à coletividade. A palavra é uma espécie de ponte lançada entre mim e os outros. Se ela se apoia sobre mim numa extremidade, na outra apoia-se sobre o meu interlocutor. A palavra é o território comum do locutor e interlocutor. (Itálico no texto original) 
Para Bakhtin, a estrutura da enunciação é determinada pelo meio e situação social. Nessa compreensão, esse meio social, bem pode ser a sala de aula, delimitada como um auditório linguístico, por se tratar de uma comunidade linguística organizada socialmente sob características éticas, culturais e linguísticas pré-determinados por sua função social e cultural. Esse terreno definir-se-ia ainda mais se localizássemos, por exemplo, as enunciações numa sala de aula de ciências, composta por uma professora e estudantes dos anos iniciais de escolarização, o que permitiria a precisão sobre o contexto e relações sociais e sobre as interações de enunciações aí produzidas. Inspirados em Bakhtin, podemos afirmar que nesse contexto social e cultural, a fala pode se tornar um "fato de linguagem".

Em um enfoque diferente de Bakhtin, mas não contraditório, Leontiev relaciona o conteúdo da comunicação ou da enunciação à atividade - contexto não tão amplo e genérico como o é meio social, tal qual delimita Bakhtin. Numa sala de aula, por assim dizer, no contexto da atividade de trabalho do professor e de estudo dos estudantes, as palavras nascem da necessidade de comunicação, da necessidade de realizar o motivo e objetivo da atividade em desenvolvimento: ensinar de modo que os estudantes se apropriem dos significados historicamente e culturalmente produzidos e de apropriação desses significados, no caso do professor e dos estudantes, respectivamente. Ou seja, o meio social indicado por Bakhtin como determinante da enunciação é aqui precisado como as relações estabelecidas entre sujeitos em atividade.

A sala de aula, concebida como um espaço multivocal, portanto, regido pelas relações mediadas e pelas tantas contradições imanentes às diferentes opiniões compartilhadas por meio da palavra, pode se constituir como uma comunidade de aprendizagem, a se compor, em outra dimensão, como uma coletividade gestora de atividades. Entretanto, coletividade é mais que um coletivo, diferenciados, sobretudo, pelos objetivos e motivos que orientam as ações numa coletividade, não tão precisos em um coletivo. Podemos dizer que numa coletividade há um movimento de construção de sentidos comuns para o grupo, ou seja, os participantes compartilham o motivo e o objetivo que estruturam a atividade, assim como compartilham a consciência sobre os laços que unificam as ações que compõe a atividade.

Portanto, numa coletividade podemos inserir os conceitos de atividade no sentido que lhe é atribuído por Leontiev e o de dialogia pronunciado por Bakhtin, este último mais abrangente do que a ideia normalmente associada à palavra "diálogo". Segundo Werstch \& Smolka (2003), o conceito dialogia aborda as muitas formas como duas ou mais vozes entram em contato. Qualquer enunciação só pode ser compreendida se entendermos sua relação com 
outras enunciações e com os motivos e objetivos que orientam a atividade determinante da enunciação. Na sala de aula, por exemplo, só podemos compreender a voz do professor em relação às vozes dos alunos e vice versa, numa dinâmica em que uma enunciação é mediada por outra enunciação, encontra voz em outra enunciação, e se realizam uma na outra. Sem deixar de considerar, em momento nenhum, as necessidades e motivos imbuídos nos objetivos da atividade orientadora das ações e enunciações do grupo.

Segundo Bakhtin, compreender é mais que ouvir e interpretar o que o outro diz: a compreensão está na raiz da realização da enunciação e, subsequentemente, da dialogia, por se tratar de um processo empenhado em combinar a palavra de quem fala com uma contra palavra. Isto é, em contextos dialógicos, as vozes se contatam e se confrontam continuamente, uma vez que a voz de uma pessoa assume as palavras e expressões de outras. É o que podemos interpretar de mais uma enunciação de Bakhtin (Bakhtin, 1981, p. 293-294 ${ }^{5}$ apud Wertsch \& Smolka, 2003, p. 129-130:

\begin{abstract}
A palavra na linguagem pertence parcialmente a outra pessoa. Ela se torna 'palavra própria' quando o falante a povoa com sua própria intenção, seu próprio sotaque, quando se apropria da palavra, adaptando-a a sua própria intenção semântica e expressiva. Antes desse momento de apropriação, a palavra não existe em uma linguagem impessoal e neutra (afinal, não é de um dicionário que o falante tira suas palavras!), mas existe na boca de outras pessoas, nos contextos concretos de outras pessoas, servindo às intenções de outras pessoas: é daí que se pode apreender uma palavra e fazer dela sua própria palavra.
\end{abstract}

Tomamos como nossas essas palavras de Bakhtin. Como palavras apropriadas ou próprias, podemos dizer que elas são povoadas com nossas intenções, carregadas com os valores culturais e com os sentidos que atribuímos às coisas do mundo. Esses valores culturais e sentidos são gradativamente construídos na atividade e na relação com o outro, a partir da apreensão da palavra do outro. As palavras de Bakhtin, apreendidas neste trabalho, povoam o território da investigação que ora desenvolvemos, a qual é constituída com nossos próprios propósitos semânticos e expressivos.

Com efeito, conceitos contidos nas obras de Bakhtin e, sobretudo, nas obras de Vigotski são conteúdos de muitos trabalhos destinados a estudar o movimento discursivo em sala de aula. Conceitos como dialogia, linguagem social, gênero da fala, natureza social do funcionamento psíquico humano, bem como o caráter mediacional das linguagens sociais são

\footnotetext{
${ }^{5}$ BAKHTIN, M. M. The dialogic imagination: four essays by M. M. Bakhtin. Editado por M. Holquist, traduzido pro C. Emerson e M. Holquist. Austin, University of Texas Press, 1981.
} 
coincidentes e complementares nos pensamento bakhtiniano e vigotskiano (Freitas, 2003; Wertsch, 1991), os quais estão presentes em inúmeros estudos inseridos no campo das pesquisas em ensino de ciências, desenvolvidos da década de 90 até os dias atuais em diferentes países.

Com a intenção de nos aproximarmos de um aspecto muito importante focalizado por esta investigação - linguagem como signo/instrumento de mediação e de aprendizagem e desenvolvimento profissional docente em aulas de ciências - passamos a discutir mais especificamente acerca dos modos como linguagem, mediação e dialogia comparecem em sala de aula. Para tanto, nos apoiamos em estudos a respeito, principalmente naqueles fundamentados na perspectiva histórico-cultural.

\subsection{Linguagem e modos de mediação docente em aulas de ciências}

A linguagem e mediação em aulas de ciências são temas recorrentes em muitas pesquisas, os quais vêm se constituindo como um foco de investigação cada vez mais abrangente. Dado ao grande número de trabalhos incluídos nesse campo de estudo fala-se numa virada discursiva, movimento assim chamado por centrar atenção no processo de comunicação e de mediação por meio da linguagem, nos discursos e em outros mecanismos retóricos utilizados pelos sujeitos no processo de ensino e aprendizagem (Mortimer \& Scott, 2002).

As investigações incluídas na virada discursiva são consideradas relevantes, exatamente, por trazerem à luz elementos essenciais que emergem das complexas relações que constituem os atos de ensinar e de aprender. $O$ modo como os significados são construídos no contexto da sala de aula, no processo dialógico estabelecido entre os sujeitos, toma o lugar da atenção centrada no desenvolvimento cognitivo do indivíduo. $\mathrm{O}$ foco passa a ser a mediação por meio da linguagem e os diferentes discursos no processo de significação desenvolvido entre os sujeitos no contexto coletivo da sala de aula. Não mais se isola como

sujeito o aluno ou o professor - um e outro são estudados no processo de ensino e aprendizagem, em que as diferentes vozes se inter-relacionam no movimento dialógico.

No âmbito desse novo olhar, a sala de aula é reconhecida como uma comunidade que cotidianamente produz cultura por meio das ações de seus sujeitos; representada por padrões de linguagens e de práticas, os quais traduzem o processo de ensino-aprendizagem (Edwards 
\& Mercer, 1988). A sala de aula passa a ser valorizada como um lugar de relações dialógicas, de novas construções inter e intrasubjetivas das quais participam professor e estudantes (Colaço et all, 2007).

Alguns estudos não muito recentes, como os de Mehan (1979), investigam a estrutura de aulas e como as interações são mediatizadas por padrões diferenciados de diálogos e perguntas; Edwards e Mercer (1988) apresentam estudos valiosos por investigarem o modo como a linguagem é apropriada por sujeitos no processo em que o conhecimento é construído e compartilhado em sala de aula; Mercer, em 1997, divulga alguns estudos sobre as "técnicas de linguagem" utilizadas por professores para guiar a construção de conhecimentos; Candela (1999) volta a sua atenção para os discursos em aula, com ênfase nas explicações, justificativas e argumentações que fazem os estudantes ao se comunicarem com seus professores; Lemke em 1997, por sua vez, discute sobre a linguagem, com destaque para a análise de padrões temáticos em aulas de ciências, com a intenção de compreender como professores e alunos falam ciências. Trata-se de trabalhos valiosos com análises e resultados que muito contribuem para as construções tecidas no âmbito desta investigação, motivo pelo qual são relembrados no decorrer das discussões e análises.

Trabalhos mais recentes, nacionais e estrangeiros, não menos importantes, analisam diferentes aspectos apreendidos do contexto de comunicação da sala de aula de ciências, os quais, em sua maioria, privilegiam, como objeto de estudo, a construção de significados pelo estudante com o olhar sobre as interações discursivas (Mortimer \& Scott, 2002; Cruz, 2002; Roth \& Lawless, 2002; Bernier, 2002; Marquez, Izquierdo \& Espinet, 2003; Monteiro \& Teixeira, 2004; Aguiar \& Mortimer, 2005; Dione, 2007; Silva \& Schnetzler, 2009; Schroeder, Ferrari \& Maestrelli, 2010; Silva \& Mortimer, 2010; Jan, Chee \& Tan, 2010; Pedrancini, Corazza-Nunes \& Galuch 2011; e outros).

Ainda em relação à aprendizagem dos estudantes, uma gama de trabalhos focaliza o processo de construção de argumentos em contextos, em que se valoriza a promoção da alfabetização ou enculturação cientifica em sala de aula (Capecchi \& Carvalho, 2000; Monteiro, Santos \& Teixeira, 2007; López Rodríguez \& Jiménez Aleixandre, 2007; Sasseron, 2008; Sasseron \& Carvalho, 2008; e outros). Nessa mesma dimensão, outras tantas pesquisas discutem a leitura e a escrita em aulas de ciências como modos de expressão da linguagem científica (Rivard \& Straw, 2000; Souza \& Almeida, 2005; Nascimento \& Martins, 2005; Mazzitelli, Maturano \& Macías, 2007; Oliveira, 2009; e outros). O uso de Tecnologias de Informação e da Comunicação (TICs) e sua influência no processo de aprendizagem em 
ciências também tem se constituído como outro importante foco de pesquisas (Giordan, 2008).

No âmbito desses estudos, os processos de aprendizagem "estão profundamente associados à aquisição e ao uso da linguagem em contextos específicos" (Vieira \& Nascimento, 2009, p. 444). Em cada contexto, os significados construídos pelos estudantes podem ser expressos, ou melhor, como diz Vigotski (2009b), "realizados", através da fala, da escrita, gestos, desenhos, entre outros recursos linguísticos. Reitera-se, desse modo, a linguagem como a verbalização das formas internas do pensamento, consubstanciada em um importante recurso de mediação semiótica e de mediatização da comunicação e compreensão e, por suposto, da viabilização da aprendizagem. A linguagem realiza-se como o signo/instrumento da aprendizagem por ser usada na atividade de "Inter pensar", ou seja, como instrumento usado para se "pensar conjuntamente, para compreender a experiência e resolver problemas coletivamente" (Mercer, 2000, p. 17).

Esses trabalhos, tantos os mais remotos quanto os mais recentes, embora considerem as múltiplas vozes e modos de realização da linguagem em sala de aula, bem como os diferentes modos de mediação, estratégias e intervenções que compõem as ações e discurso docente, focalizam em primeiro plano o movimento discursivo dos estudantes. As intervenções docentes são analisadas e consideradas como ponto de referência para o estudo da aprendizagem do estudante no processo dialógico. A formação e aprendizagem do professor são temáticas que ainda comparecem em pequena quantidade nas pesquisas inseridas no campo da linguagem em aulas de ciências. Eis alguns dos poucos trabalhos a respeito: Andrade \& Martins, 2006; Lima \& Maués, 2006; Scarinci \& Pacca, 2009; Vieira \& Nascimento, 2009.

Contudo, ainda que não abordem diretamente a formação de professores, muitos dos trabalhos supracitados, ao tecerem suas análises e resultados, indicam importantes elementos que contribuem com os estudos nessa área, por revelarem minúcias do cotidiano da sala de aula, principalmente no que diz respeito aos modos de mediação docente e à dialogia estabelecidas entre as enunciações que permeiam as relações entre os sujeitos, e os desafios de se ensinar e de se aprender os variados significados imanentes à cultura científica. Esses estudos analisam a atuação ou modos de mediação docente sob diferenciados aspectos, a saber: intenções, conteúdos de seus discursos, padrões de comunicação e de interações, formas de intervenção, de estratégias e de atitudes, procedimentos didáticos discursivos, entre outros. 
Os resultados dessas análises se inserem no campo de interesse de nossa investigação, pois os nossos esforços se dirigem exatamente para melhor entender a atuação docente, na busca de subsídios para discutirmos sobre a relação aprendizagem e desenvolvimento profissional docente. Portanto, destacamos a seguir, aqueles elementos que, a nosso ver, mais se aproximam desse corpo de intenções.

Em uma abordagem geral desses estudos, constata-se que tanto o ensino como a comunicação são concebidos como processos sociais, o que nos faz olhar com mais cuidado para a atuação do professor, valorizando não apenas conhecimentos e atitudes, mas valores e interesses sociais (Lemke, 1997; 1998). Sem dúvida, estamos diante de uma nova expectativa quanto ao papel do professor - como um tutor e como usuário da linguagem, esse profissional pode levar os alunos a novos níveis de compreensão conceitual mediante a fala com eles, ou seja, mediante a comunicação. Não devemos esquecer que a linguagem é tanto instrumento como signo mediacional do professor e do estudante, usado exaustivamente tanto para ensinar como para aprender, respectivamente.

O grande desafio do professor ao assumir esse novo papel é transformar sua sala de aula numa comunidade, na qual a linguagem científica possa ser introduzida, de modo que se ensine e se aprenda a falar ciências. Aprender ciências consiste em aprender a falar ciências, o que não se traduz na repetição de conhecimentos transmitidos por outros e nem na expressão de termos científicos isolados entre si; falar ciências significa comunicar ciências, fazer ciências por meio da linguagem, utilizando os seus recursos semânticos (Lemke, 1997; 1998; Dione, 2007; Jan, Chee, Tan, 2010). Semântica seria o estudo do significado tal como este se apresenta através da linguagem; o estudo de como usamos a linguagem para expressar a relação entre significados de diferentes conceitos.

Ensinar a falar ciências inclui ainda outros aspectos importantes, ressaltados por Lemke (1997), tais como: promover discussões sobre as ideias prévias dos alunos sobre determinado tópico a fim de levá-los a reconhecer as diferenças e semelhanças entre o sentido comum destas ideias e o que diz a ciência; ensinar os alunos a estabelecer relações entre a linguagem coloquial e a científica tanto em textos escritos quanto na oralidade; comunicar a ciência a seus alunos, utilizando não apenas os meios estilísticos e retóricos próprios da linguagem científica, mas incluir formas alternativas como a narrativa, metáfora, humor, ensinando-os a distinguir o momento adequado para uso de ambas as formas; enfatizar o lado humano da ciência, levando os alunos a vê-la como uma atividade produzida por seres humanos reais, sendo as teorias científicas mutáveis; enfatizar que a ciência não é a única 
forma de falar acerca do mundo e, que embora seja importante e útil, não é a melhor; discutir os planos de ação com seus alunos, não os obrigando a estudar temas que não estão entre os seus níveis de compreensão. Para esse autor, o objetivo de ensinar a falar ciências pode ser cumprido por meio do diálogo e da reconstrução da experiência perceptiva no discurso científico escolar.

Como formadores de professores e pesquisadores, devemos considerar a complexidade desse objetivo, posto que estabelecer a comunicação em aulas de ciências, seja para crianças ou para adolescentes e adultos, não é algo simples e corriqueiro. Ao contrário, como afirma o próprio Lemke (1997), nem sempre professores e alunos se comunicam, pois a linguagem pode ser usada de formas diferentes por esses sujeitos: professores podem falar ciências enquanto que alunos podem não fazê-lo; alunos podem, por exemplo, apresentar padrões temáticos conflituosos em relação aos desenvolvidos pelos professores.

Segundo Edwards \& Mercer (1988), não se pode deixar de levar em conta os muitos aspectos que influenciam e até limitam o processo de comunicação em classe, e nem minimizar as responsabilidades do professor, visto socialmente como representante de uma cultura e de um corpo de conhecimentos. Ao focalizarmos o professor de ciências dos anos iniciais, é preciso que se considere suas dificuldades imediatas, bem como os limites de recursos diante da sua responsabilidade de ensinar para um grupo de crianças.

Ensinar crianças a falar ciências se constitui em um desafio para o professor desse nível de ensino, cuja formação polivalente não o prepara para ensinar ciências especificamente. Embora a ideia de que esse professor não se sente preparado e seguro para ensinar ciências seja consensual em muitos estudos (Fracalanza, 1987; Appleton e Kindt, 1992; Delizoicov \& Angotti, 1990; Paixão \& Cachapuz, 1999), alguns autores, entre eles, Lima \& Maués (2006) relativizam esses resultados, ao questionarem se o fato de se ter pouco conhecimento dos conteúdos conceituais influencia de forma crucial o ensino, uma vez que há evidências de que se é possível ensinar ciências sem dominar satisfatoriamente os conteúdos dessa área. Para essas autoras, dois aspectos devem ser lembrados, o de que as dificuldades sobre os conteúdos acometem professores dos diferentes níveis do ensino; e o de que professores polivalentes são capazes de mobilizar conhecimentos das outras áreas, o que pode enriquecer o processo de ensino/aprendizagem e reparar determinadas deficiências.

É preciso refletir sobre tais resultados com o cuidado de nem sobrecarregar o professor e nem isentá-lo por completo do domínio sobre os conteúdos. Evidentemente, não é possível ter domínio pleno sobre os conteúdos, e nem a total segurança sobre o ensino se 
justifica apenas sobre esse domínio, entretanto, não há como negar de que determinado nível de conhecimento sobre o que se está ensinando, é importante. O conhecimento é, a um só tempo, matéria prima e instrumento/signo do professor, sobretudo quando se está inserido em um contexto profissional, onde se privilegia a docência constituída pelos atos de planejar, desenvolver e interpretar. Nesse contexto, a deficiência em relação aos conteúdos pode ser superada por meio do trabalho coletivo e da prática do estudo e da pesquisa. A predisposição ao estudo e à pesquisa pode ser considerada como um compromisso epistemológico do professor com os conhecimentos da área, o que lhe possibilitará ensinar a falar ciências, mesmo que não seja um expert nessa tão complexa área de ensino e de estudo (Azevedo, 2008; Azevedo \& Abib, 2010).

Os muitos estudos sobre linguagem em sala de aula de ciências, citados acima, podem nos falar da versatilidade do professor na busca por atingir seu objetivo mediante seu trabalho, tendo ou não pleno domínio sobre os conteúdos conceituais. Professores lançam mão de diferentes maneiras para ensinar, desde as mais frequentes e que exigem poucos recursos até aquelas mais complexas, com ações experimentais ou com recursos tecnológicos. Os modos de mediação docente são tão diversificados a ponto de levarem autores como Mortimer \& Scott (2002, p. 284) a se dizerem impressionados com as variadas maneiras pelas quais professores medeiam a relação com seus estudantes: "em algumas salas, as palavras estão por toda parte".

Para Vieira \& Nascimento (2009), essas variadas maneiras de gerenciamento e controle sobre o movimento dialógico em sala de aula podem estar relacionadas aos modos como se concebe o processo de construção de significados pelos estudantes, o que parece fazer sentido se relacionarmos a diversidade de intervenções docentes a contextos em que se valoriza a aprendizagem mediante a comunicação. Possivelmente, as intervenções do professor que privilegia a transmissão de conhecimentos e a sua recepção pelos estudantes, podem não ser tão diversificadas.

Esse processo de comunicação em aulas de ciências tem sido estudado a partir de padrões de diálogo. É consensual a presença do diálogo triádico, aquele municiado por pergunta, resposta e avaliação, cuja sequência de fala é iniciada por um pergunta avaliativa ou de exame e finalizada pelo professor por uma avaliação (Mehan, 1979; Lemke, 1997; Werstch, 1999; Edwards \& Mercer, 1988; Mortimer \& Scoth, 2002; Aguiar \& Mortimer, 2005; Jan, Chee \&Tan, 2010 e outros). Nesse modelo de diálogo, o professor inicia o diálogo (I), os estudantes respondem (R) e o professor dá o retorno avaliativo (E). Aos olhos desses 
pesquisadores, essa relação tripartida ou padrão I-R-E (Initiation - Response - Evaluation) reflete elementos essenciais do discurso estabelecido entre professor e estudantes, frequente e predominante em contextos em que se privilegia a transmissão unidirecional de conhecimentos.

Entre esses elementos podemos destacar o fato de que a maioria das perguntas é feita pelo docente com intenções que vão desde checar o conhecimento do estudante a controlar as relações de poder e autoridade na classe. Por meio desse padrão de diálogo, a relação de poder é assimétrica, em que o professor detém quase que completamente o discurso, restando para o aluno o papel de responder as perguntas que lhe são dirigidas.

Outro elemento refletido pelo padrão I-R-E avaliativo é a relação do professor sobre o conhecimento ou padrão temático em desenvolvimento na aula. Essa relação de domínio ou de aparente domínio é revelada pelo fato do professor perguntar o que já se sabe, ou seja, o que já se pode prever como resposta. Muitas vezes, repete a resposta do aluno, avaliando-a positivamente; em caso de não se obter a resposta desejada, fica em silêncio ou repete a pergunta. Nas aulas em que se verifica o predomínio desse padrão de diálogo, os estudantes perguntam menos, falam muito pouco e escrevem menos (Lemke, 1997).

Embora a permanência desse modelo de diálogo seja avaliada como de pouco impacto positivo para o processo de aprendizagem dos estudantes, alguns estudos ponderam esses resultados, ao suporem que as perguntas que iniciam a sequência das falas, mesmo em caráter avaliativo, podem ser eficazes e podem ser consideradas importantes e produtivas para a educação (Wertsch, 1999). A principal reclamação se situa em seu predomínio, tomando o lugar das cadeias de diálogo mais abertas, em que a participação e a voz do aluno são mais valorizadas. Segundo Capecchi \& Carvalho (2000), mesmo sob o padrão I-R-E, verifica-se que se o professor, ao invés de avaliar a resposta do estudante, acrescentar novas ideias à discussão, estaria, em certa medida, introduzindo um novo padrão e enriquecendo a comunicação em sua aula.

Todavia, há quem tenha outra avaliação. Para Lemke (1997), por exemplo, a aula bem poderia ser organizada, de modo que os alunos dispusessem de mais tempo para perguntas, intervenções, dúvidas, discussões orais acerca de temas e escritas sobre os mesmos, além de trabalharem em grupo. Nessa mesma direção, outros estudos indicam que nem sempre a sequência de fala finaliza na avaliação feita pelo professor sobre a resposta do aluno, destacando a presença de cadeias de diálogo abertas em diferentes processos de comunicação observados. Monteiro \& Teixeira (2004) são alguns dos autores que evidenciam 
situações em que a iniciação enunciada pelo professor é a introdução de um problema, sendo este sequenciado por intervenções dos alunos, que podem ser respostas ou perguntas. A última pessoa da cadeia não é necessariamente o professor, e se for, não necessariamente profere uma enunciação avaliativa.

Mortimer \& Scott (2002) valorizam tais resultados, ao apresentarem estudos realizados em contextos em que o processo de comunicação é composto com o predomínio de sequências de falas abertas, nos quais se presenciam intervenções docentes mediadas por diferentes enunciados. Professores se comunicam com seus alunos por meio de enunciados compostos por descrição de determinados objetos, fenômenos ou sistemas descritivos; por meio de explicações apoiadas em alguns modelos teóricos e por generalizações. Professores selecionam, marcam e compartilham significados a partir da exploração das ideias dos estudantes, complementando-as e repetindo-as para a classe; a partir da introdução de novos elementos científicos e da recapitulação e antecipação de conteúdos. Esses resultados coadunam com outros apresentados por Monteiro \& Teixeira (2004), em situações em que professores, no intuito de mediar a comunicação, problematizam, solicitam informações, fornecem pistas, preenchem as lacunas dos estudantes com informações, encorajam a sua participação, avaliam o rumo do processo discursivo desencadeado em classe, reorganizam proposições e recolocam intervenções.

No âmbito desses contextos, presenciam-se perguntas chamadas autênticas, tanto enunciadas pelo professor como pelos alunos, caracterizadas como aquelas em que o locutor não tem uma resposta pré-estabelecida: pergunta-se sobre o que não se sabe e se deseja saber. Segundo Werstch (1999) as perguntas autênticas compõem contextos de comunicação dialógicos, nos quais o professor, ao perguntar, sinala para os alunos interesse pelo que eles pensam e sabem; convida os alunos a contribuir com algo novo à discussão, podendo mudá-la ou modificá-la de alguma maneira. Em tais situações, contamos com perguntas proferidas por estudantes quase sempre sob o caráter de autenticidade, pois esses, sobretudo quando são crianças, perguntam porque querem saber e, dificilmente, perguntam para testar ou avaliar o conhecimento do professor.

Há pesquisas que privilegiam o estudo sobre a participação e perguntas dos estudantes, como é o caso das investigações realizadas por Aguiar, Mortimer \& Scott (2006) e Aguiar, Mendonça \& Silva (2007). Ambos os trabalhos baseiam-se principalmente em Candela (1999) para discutir o caráter das perguntas feitas pelos estudantes. Constatam a presença de perguntas de esclarecimento ou extensão, quando proferida à busca de 
informações complementares; de extrapolação, quando se busca informações que vão além da estrutura explicativa do professor; perguntas de contestação, por desafiarem a estrutura explicativa proposta pelo professor; e perguntas de agenda, assim denominadas por não serem relacionadas ao conteúdo em desenvolvimento. Além de perguntarem, os estudantes respondem questões, relatam acontecimentos, leem em voz alta, e outras intervenções.

É consensual no corpo dos trabalhos referenciados a ideia de que os estudantes falam e perguntam mais em contextos em que as intervenções docentes são mais diversificadas. Quanto mais variados forem os modos de mediação, mais se contribui para o enriquecimento do processo de comunicação, sobretudo no que diz respeito à participação dos estudantes. Além da variedade dos recursos discursivos, a qualidade e o conteúdo dos discursos no processo dialógico também influenciam essa participação.

O conteúdo dos discursos é discutido por Wertsch (1999) com base nos conceitos de discurso de autoridade e de discurso internamente persuasivo, delimitados por Bakhtin. $\mathrm{O}$ discurso de autoridade se caracteriza pelo dogmatismo vinculado às palavras, por ser imbuído de um poder que impõe uma diferença hierárquica entre os interlocutores e uma distância entre eles. Por outro lado, o discurso persuasivo se distingue do discurso de autoridade por envolver as pessoas em diálogos, por aproximá-las, sendo a palavra persuasiva concebida como um recurso do pensamento, "como um ponto de partida para uma resposta que pode incorporar e mudar a forma e o sentido do que originalmente se diz" (Wertsch, 1999, p. 111). Para Bakhtin, "a palavra internamente persuasiva é metade nossa e metade de outro" (Bakhtin, $1981^{6}$, p. 345 apud Wertsch, 1999, p. 111).

Essa distinção entre discurso de autoridade e discurso persuasivo inspirou Mortimer e colaboradores a discutir o conteúdo e qualidade do discurso em aulas de ciências, classificando-o como discurso dialógico e de autoridade e como discurso interativo e não interativo (Mortimer \& Scott, 2002; Mendonça, Aguiar \& Silva, 2008; Aguiar \& Mortimer, 2005). Quando várias vozes são consideradas, diferentes pontos de vistas respeitados, havendo uma "Inter animação de ideias", define-se como discurso dialógico e interativo; quando apenas uma voz e um ponto de vista são considerados, discute-se como discurso de autoridade e não interativo. Segundo Mortimer \& Scott (2002), no âmbito das relações estabelecidas em aulas, uma interação discursiva pode conter aspectos dos diferentes discursos, não se caracterizando linearmente como uma ou outra com o que, a princípio concordamos.

\footnotetext{
${ }^{6}$ Idem referência página 34.
} 
Entretanto, a despeito do que é dito por Mortimer \& Scott (2002) sobre essa variedade na composição do discurso na abrangência das interações discursivas, outras investigações indicam que na sala de aula de ciências ainda se predomina o caráter não dialógico do discurso, em que o professor, embora objetive a aprendizagem dos estudantes, não lhes garante muito espaço de participação. Estudos desenvolvidos na década de $70 \mathrm{em}$ diferentes países e escolas (FIAC; Flanders, 1970) citados por Edwards \& Mercer (1988, p. 39) divulgam a conhecida regra dos dois terços ainda frequente na sala de aula: "a) durante aproximadamente dois terços do tempo alguém fala; b) aproximadamente dois terços da conversação são feitos pelo professor; c) aproximadamente dois terços da conversação do professor consistem em leitura ou perguntas".

Não temos dúvida de que a voz do professor é predominante e as suas contínuas intervenções são necessárias em aulas organizadas sob qualquer orientação metodológica. Contudo, o que se tem sido problematizado não é simplesmente a predominância da voz do professor, mas o fato do seu discurso se ocupar em grande parte do tempo ao controle da disciplina e à organização da aula (Werstch, 1999), ou a leituras e a perguntas, como mostra a regra dos dois terços. Esse discurso bem poderia se ocupar majoritariamente da construção de um ensino que objetivasse a criação de necessidades e motivos de aprendizagem para os sujeitos envolvidos: professores e estudantes.

Os resultados apresentados pelas investigações referenciadas no corpo deste texto nos dizem da necessidade de mudança nessa maneira ainda predominante de se ensinar ciências, na perspectiva de se construir ambientes ou contextos de aprendizagem, em que se presenciem mobilidades na gestão da classe e nas ações do professor e dos estudantes, como resoluções de problemas mediadas por atividades experimentais, rodas de conversa e de leituras, oportunidades para se falar e escrever mais sobre assuntos científicos, entre outras possibilidades. Tal qual nas comunicações mediadas pelo discurso dialógico, consolidado nas cadeias ou sequencias de fala abertas, em que o estudante tem mais espaço de participação e a sua voz tem sido mais considerada como signo e instrumento de mediação de sua própria aprendizagem.

No caso específico desta pesquisa, os diferenciados modos de mediação docente e recursos linguísticos postos em discussão nos estudos supracitados, além de nos mostrarem a complexidade das relações de ensino e reiterarem o importante papel da linguagem como função semiótica no processo de mediação docente, contribuem com subsídios para que 
possamos construir a unidade de análise, a qual nos orientará na construção do instrumento analítico.

Ao submergirmos nas complexas relações da sala de aula, olhando-as a partir de conceitos como mediação, enunciação e dialogia, reafirmamos a mediação como o princípio regulador de todas as ações. As ações que compõem a atividade docente são mediadas pela linguagem, concebida como signo/instrumento, posicionada entre o professor e o estudante no processo de ensino/aprendizagem.

A partir destas reflexões, supomos a integração ação docente e linguagem como unidade de análise desta investigação, aqui denominada de mediação discursiva docente. Por se consubstanciar como uma unidade, a mediação discursiva docente guarda os inúmeros aspectos que compõem a totalidade das relações mediadas da atividade do professor.

No próximo capítulo, ao discutirmos sobre os motivos e objetivos desta pesquisa, bem como quando apresentarmos o seu método de análise, retomaremos a discussão sobre a mediação discursiva docente e o seu potencial, como unidade de análise, de conter e expressar elementos que subsidiarão as reflexões sobre a relação aprendizagem e desenvolvimento profissional docente - foco de estudo deste trabalho. 


\title{
Capítulo III - A PESQUISA: contexto e metodologia
}

\author{
Se a essência dos objetos coincidisse com a forma de \\ suas manifestações externas, então toda ciência seria \\ supérflua.
}

Karl Marx

A primeira parte deste capítulo é dedicada à apresentação do contexto escolar, onde esta pesquisa acontece e de onde emergem seus principais motivos. A intenção é reunir elementos que contribuam com a melhor compreensão sobre os projetos em ensino de ciências desenvolvidos pelos professores dos anos iniciais de escolarização. Na segunda parte, focalizamos a metodologia, com discussões teóricas sobre o método e com as discriminações dos passos metodológicos: apreensão do fenômeno e objeto da pesquisa; instrumentos de coleta de dados e os sujeitos da pesquisa.

\subsection{A escola e os processos formativos em ciências}

A EMEF Candido Portinari, escola da rede Municipal de Ensino da cidade de São Paulo, localiza-se em Perus, bairro periférico situado ao extremo noroeste do município. Atualmente esta escola atende a cerca de 1.300 alunos do Ensino Fundamental I e II, Regular e Suplência. Há quatro anos, aderiu ao programa do MEC "Ensino Fundamental para os Nove Anos", portanto, ainda em processo. Bem estruturada fisicamente, essa escola possui, além das 16 salas de aula, 05 salas ambiente (Laboratório de Ciências, Sala de Leitura, Laboratório de Informática, Sala de Artes e Sala de vídeo). Contempla o programa Educação Inclusiva, com sala equipada para atendimento especializado a alunos com necessidades especiais.

As classes são compostas por cerca de 35 estudantes, com acentuado grau de heterogeneidade em relação a níveis de aprendizagem. Em sua maioria, as famílias, cujos filhos frequentam a escola, compõem um quadro desfavorável do ponto de vista sócio econômico. Como em qualquer bairro da periferia da cidade de São Paulo, essas famílias estão expostas aos diferenciados problemas gerados pela atual sociedade, como desemprego, precárias condições de moradias, entre tantos outros. 
Embora contenha características que são comuns às demais escolas da região, essa EMEF guarda algumas peculiaridades em relação à realização de projetos pedagógicos e à constituição de grupos colaborativos de trabalho entre seus professores. A guisa de exemplo, lembramo-nos do Projeto Interdisciplinar promovido pela Secretaria Municipal de Educação, inserido no Movimento de Reorientação Curricular instaurado no início da década de 90, do qual a EMEF Candido Portinari participou como escola piloto. Entre os resultados obtidos, ressaltamos a formação de um núcleo de professores que persistiria, mesmo após o fim desse projeto, a trilhar na busca por melhorias na qualidade do ensino por meio da implementação de variadas ações nas diferentes áreas do conhecimento.

Essa busca pela melhoria do ensino na EMEF Candido Portinari se manifesta e se intensifica com a construção do Laboratório de Ciências em 1995 por meio de um projeto coordenado pela pesquisadora, a qual pertence ao quadro docente dessa escola desde 1993, como professora de ciências. Ainda que a história de construção desse laboratório já tenha sido narrada em estudos realizados anteriormente (Azevedo, 2008), fazemos questão de rememorar alguns aspectos marcantes, os quais falam por si só da persistência do grupo em melhorar a sua atuação docente e a qualidade de suas aulas, sobretudo em ciências.

De fato, não há como negar o grau de envolvimento e determinação do coletivo de professoras na época em criar um espaço que oferecesse novas condições para se ensinar ciências. Como não havia salas disponíveis, empenhou-se na reforma de um banheiro desativado, o qual, em menos de dois meses, já estava funcionando como um laboratório com acomodações para metade de uma classe. Outro aspecto que merece ser lembrado foi o fato dos gastos financeiros com a reforma e compra dos primeiros materiais não terem sido cobertos por verbas oficiais, mas por contribuições advindas da comunidade escolar. Lembramos ainda que foram os professores dos anos iniciais os que mais se envolveram com as ações desenvolvidas desde a construção e reforma do espaço à organização e realização das atividades de ciências no laboratório.

Recordar esses aspectos nos leva a refletir sobre os possíveis motivos que mobilizaram o grupo a direcionar suas ações para a busca de melhorias no ensino de ciências. Possivelmente esses motivos estavam relacionados aos anseios de mudanças gestados na época pelo Movimento de Reorientação Curricular de 1990, o qual, de um modo ou de outro, pode ter despertado na equipe docente a necessidade de se repensar o ensino em suas diversas áreas. 
O certo é que o Laboratório de Ciências pode ser visto como um projeto bem sucedido na escola, a considerar seu percurso, desde a sua construção até os dias atuais. A sua permanência na escola prova a fertilidade do ambiente que lhe deu origem e a seriedade do grupo de professores que o conduziu ao longo desse período. Atualmente, esse laboratório é visto não apenas como um espaço físico grande e bem equipado, mas como um equipamento de apoio pedagógico aos professores das diversas áreas, com prioridade para o ensino de ciências nos anos iniciais.

Há algum tempo, o laboratório vem se constituindo como um espaço de aprendizagem nos âmbito da docência em ciências e da aprendizagem dos alunos, como tal, respeitado por professores e pais, respectivamente. Essa assertiva é respaldada pelo fato ocorrido em 2008, quando a Delegacia Regional de Ensino impôs a transformação do laboratório em uma sala de aula comum para atender a abrupta redução de 04 para 03 dos turnos de funcionamento da escola. A comunidade, organizada por meio do Conselho Escolar e do Movimento de Educação do bairro, reagiu a essa imposição direcionando uma carta $^{7}$ à direção da escola, à Coordenadora de Educação da região e ao Secretário Municipal de Educação, exigindo a continuidade do laboratório. Felizmente, a voz da comunidade foi ouvida.

A aprendizagem docente, por sua vez, é refletida nos avanços relacionados às práticas pedagógicas, os quais vêm se configurando na orientação metodológica para o ensino de ciências em construção ao longo desses anos. É consensual entre os professores envolvidos, a opção pela organização do ensino de ciências via orientação investigativa, a qual vem, gradativamente, se formando sob influência dos processos formativos realizados no âmbito da escola e das parcerias estabelecidas com outros projetos e instituições.

Não há dúvida de que a jornada de trabalho docente, denominada de JEIF (Jornada Especial de Formação), cumprida por grande parte dos professores na rede municipal de ensino da cidade de São Paulo, favorece o desenvolvimento de processos de formação contínua na escola, por ter em sua constituição, além do tempo de trabalho em sala de aula, 11 horas/aula semanais destinadas ao estudo na escola, com 03 horas individuais e 08 coletivas. No caso da EMEF Candido Portinari, 04 dessas 08 horas/aulas, são reservadas para discutir acerca dos projetos em realização, entre eles o processo formativo em ensino de ciências desencadeado pelo Laboratório de Ciências. Participam diretamente desse processo formativo

\footnotetext{
${ }^{7}$ Cópia da carta em anexo.
} 
as professoras do Ensino Fundamental I. Outros professores ligados às áreas de geografia, matemática e artes do Ensino Fundamental II utilizam o espaço do laboratório para desenvolvimento de seus projetos, integrando-se e colaborando em muitos momentos com a formação das professoras do Ensino Fundamental I.

Especialmente, o processo formativo em ciências movimenta-se no cotidiano da escola mediante a realização de Atividades Investigativas de Ensino (AIE), com pressupostos metodológicos que se aproximam aos de uma pesquisa-ação na formação de professores. A AIE privilegia a organização do ensino e da aprendizagem por meio de atividades investigativas, em um processo em que as professoras em formação são mobilizadas para buscar soluções para problemas de ensino preestabelecidos por elas próprias.

O problema que orienta e desencadeia a Atividade Investigativa de Ensino (AIE) é alimentado pelas necessidades oriundas do Projeto Pedagógico da escola. Dessas necessidades origina-se o motivo do professor em querer criar oportunidades de aprendizagem para suas crianças. Desse motivo decorre o planejamento de ações ou de hipóteses de trabalho destinadas à resolução do problema. Cada hipótese de trabalho é estruturada em Atividade Investigativa de Aprendizagem (AIA), a qual é conduzida pelo professor e desenvolvida pelos alunos em sala de aula. Os resultados, observados pelos professores no processo de condução dessas atividades, são por eles interpretados e analisados, podendo gerar reformulações e delimitações de novos problemas de ensino. A partir desses novos problemas, os ciclos autorreflexivos podem ser reiniciados. Esse movimento cíclico composto pelos atos de planejar, desenvolver e interpretar, assim como o caráter coletivo e colaborativo das ações docentes, é a principal aproximação desse processo formativo com os pressupostos da pesquisa-ação.

O esquema seguinte sintetiza as ações em uma Atividade Investigativa de Ensino: 
Figura 04 - Estrutura das atividades de organização do ensino

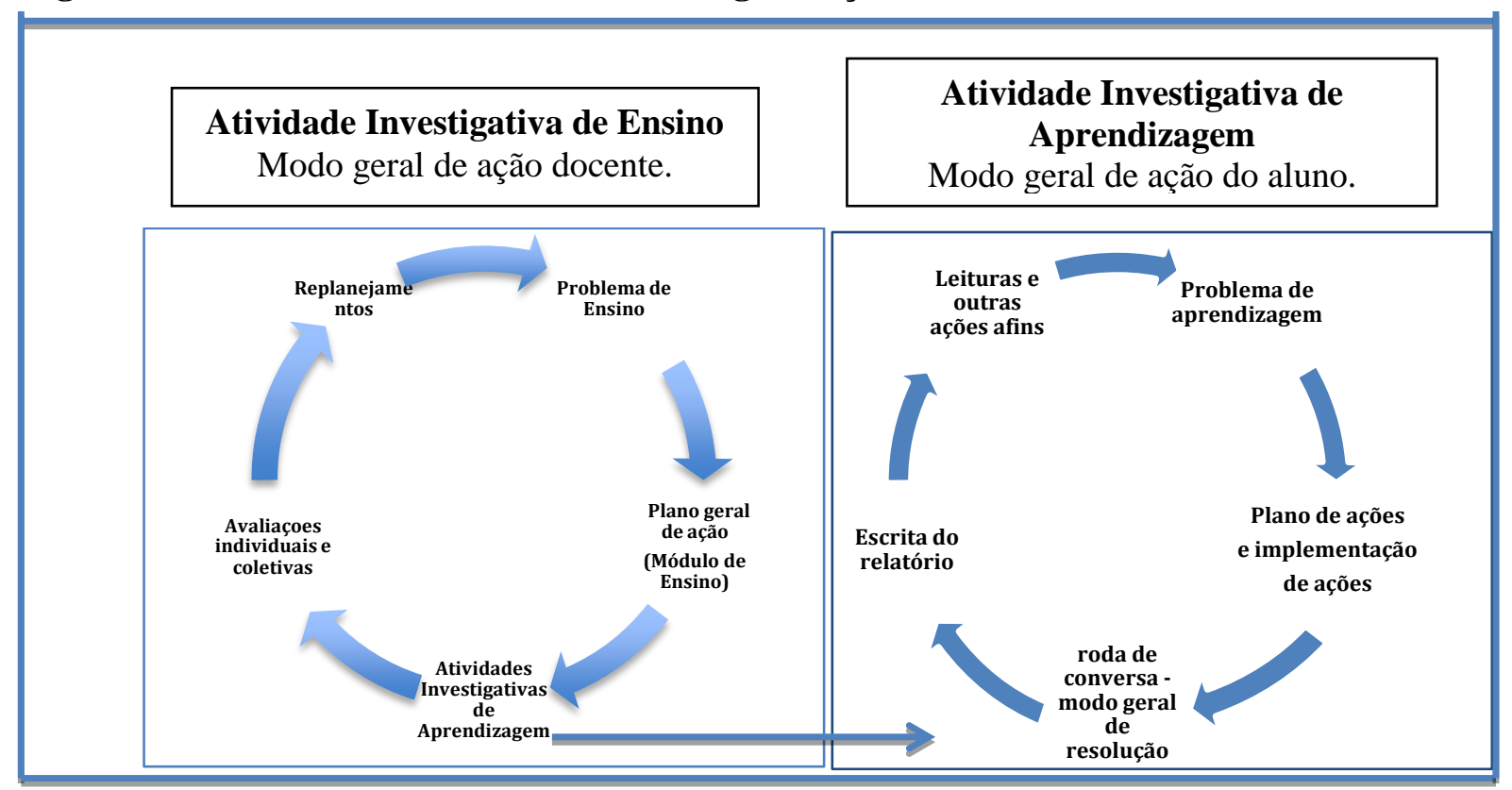

Fonte: informações organizadas pela autora.

A Atividade Investigativa de Ensino reúne as formas gerais de ação docente, sendo o professor o seu sujeito. Nota-se no esquema que a Atividade Investigativa de Aprendizagem (AIA) nasce no interior da AIE, concebida como a materialização do plano de ação docente em busca da resolução do seu problema de ensino.

A Atividade Investigativa de Aprendizagem consiste nas formas gerais de ações do aluno trilhadas para resolver o problema de aprendizagem. Conduzida pelo professor e desenvolvida pelo aluno, a AIA é composta por diferenciadas ações e operações, como realizar experimentações, pesquisar em variadas fontes, participar de rodas de conversa, escrever relatórios, leituras diversas, assistir a filmes, entre outras, voltadas para a resolução do problema de aprendizagem. Para compor a atividade, essas ações devem estar orientadas e correlacionadas com o motivo/objetivo contido no problema que a orienta.

Em cada atividade, o problema é do sujeito, porque nasce de suas próprias necessidades, de seus motivos e sentidos atribuídos por ele próprio a suas atividades de ensino ou de aprendizagem, do professor e do aluno, respectivamente (Moura, 2000; Azevedo, 2013).

Cada problema contém em si a necessidade e o motivo/objetivo que o origina: o problema de ensino nasce da necessidade de ensinar de modo que os alunos formem o conceito; enquanto que a necessidade do problema de aprendizagem é cognitiva, explicita no motivo do aluno em formar o conceito. 
O movimento de realização das Atividades Investigativas de Ensino tem em si o potencial de organização do ensino, resultando por articular o ensino com a aprendizagem, a aprendizagem do professor com a aprendizagem do aluno: professores resolvem problemas de ensino para aprender a ensinar e para melhor ensinar, enquanto os alunos resolvem problemas de aprendizagem para se apropriarem dos significados em ciências (Azevedo, 2008; Azevedp, 2013).

Como já foi dito, esse processo formativo, praticado há algum tempo como modo de organização do ensino de ciências nos anos iniciais, já foi analisado em pesquisa anterior (Azevedo, 2008), com indicativas que reforçaram a sua importância por contribuir com a elaboração de saberes docentes em ciências pelas professoras envolvidas. A socialização dos resultados desse estudo trouxe novas possibilidades formativas para a escola e seu coletivo docente. Em novembro de 2007, a escola, em nome de sua coordenadora, recebeu o convite do Laboratório de Pesquisas em Ensino de Física (LaPEF) da Faculdade de Educação da USP, para o estabelecimento de uma parceria colaborativa. A intenção da equipe do LaPEF era testar em uma escola pública sequências didáticas de Ciências que vinham planejando a fim de verificar resultados relacionados à aprendizagem dos alunos do Ensino Fundamental I. Pretendia ainda comparar esses resultados com outros obtidos por uma investigação em andamento na época (Sasseron, 2008) na Escola de Aplicação da Universidade de São Paulo.

As equipes docente e gestora da escola respondem ao convite com a imposição de algumas condições à viabilização da parceria: aceitariam se, em troca, as pesquisadoras do LaPEF garantissem um processo de formação para os professores da escola, tanto para aqueles que iriam aplicar as sequências em ciências, como para os dos demais níveis e áreas de ensino. Tal proposição seria colocada em prática com a constituição de dois fóruns, um na escola, específico para a formação na área de ciências, e outro na FEUSP, realizado sob caráter interdisciplinar. Esses fóruns foram denominados, respectivamente, de Fórum I e Fórum II.

De posse de suas pretensões e proposições, as instituições pretensamente parceiras, estreitam seus contatos por meio de reuniões que ocorriam na FEUSP com a presença de membros do grupo de pesquisa do LaPEF e representantes da coordenação da escola. Nas primeiras reuniões, as conversas centraram-se nos anseios e nas necessidades de cada uma das partes envolvidas, concluindo-se pela percepção de que ambas as instituições tinham intenções confluentes. 
De seu lado, a EMEF Cândido Portinari procurava ampliar seus processos formativos na perspectiva de continuidade e valorização do movimento em construção a partir do Laboratório de Ciências. A receptividade da escola à proposta da parceria se dava, sobretudo pelo reconhecimento por parte da equipe docente de seus limites, no que diz respeito aos aprofundamentos teóricos necessários à reflexão docente sobre seus processos de trabalho. Outro aspecto que mobilizou a escola foi o reconhecimento de similaridades entre a proposta metodológica para o ensino de ciências em construção na escola com aquela que fundamenta a produção das sequencias pelo LaPEF. Ambas as instituições privilegiam a orientação investigativa para a realização do ensino de ciências.

Do outro lado, as pesquisadoras do LaPEF, além de testar suas sequências didáticas em salas de aulas de uma escola pública, desejavam coletar dados a partir de filmagens das aulas ministradas pelas professoras em todo o processo de desenvolvimento das atividades, para posterior análise por pesquisadores da escola e do LaPEF.

Após os acordos firmados, deu-se início aos trabalhos da parceria com a primeira reunião do Fórum I. No ano de 2008, essas reuniões ocorreram quinzenalmente, em horários coletivos de estudo, dos quais participavam as professoras dos anos iniciais e, pelo menos, uma pesquisadora do LaPEF. A prioridade era preparar as professoras para aplicar as sequências, com ênfase para a metodologia investigativa, orientação sob a qual se pautam as atividades que compõem as sequências. Essa preparação se consubstanciava com a articulação das discussões de cunho metodológico com a abordagem conceitual e epistemológica própria da área de ciências. Vale esclarecer que a qualidade das discussões superava a visão técnica do fazer para reproduzir a posteriori, uma vez que se privilegiava a introdução de elementos teóricos articulados ao objeto de estudo e de trabalho, fundamentais na formação da base conceitual do pensamento das professoras. Essas discussões ocorriam concomitantemente ao desenvolvimento das atividades em sala de aula.

Há uma ressalva importante a fazer em relação à aplicação das sequências. Antes de iniciar o processo de aplicação, as professoras se detiveram no estudo dos conteúdos das sequências, as adequando às suas necessidades referentes aos seus próprios estilos e à organização temporal compatível com o modo como o currículo e o ensino eram organizados na escola. Com isso, elas queriam garantir, dentro das possibilidades, a sua autonomia como professoras, envolvidas, há algum tempo, em processos formativos com intenções explícitas de se autoformarem com domínio sobre seu processo de trabalho. Cabe destacar que a introdução das atividades planejadas pelo LaPEF, bem como o modelo formativo centrado na aplicação das sequências, não inviabilizou a continuidade da realização da Atividades 
Investigativas de Ensino pelas professoras, as quais continuaram a produzir e a desenvolver as atividades planejadas e estruturadas por elas próprias. O material do LaPEF acabou por se tornar uma importante fonte de conhecimentos e de apoio ao trabalho docente em ciências.

Simultaneamente à ocorrência das reuniões do fórum I na escola e à aplicação das sequências pelas professoras ocorriam bimestralmente na FEUSP, os encontros formativos do Fórum II. De caráter interdisciplinar e mais teórico, esse fórum reunia professores da escola de outros níveis de ensino, além das professoras dos anos iniciais. A coordenação desse fórum era dividida entre uma pesquisadora do LaPEF e um professor da FEUSP. As pautas cumpridas nesses encontros eram organizadas, de modo que a primeira parte da reunião era destinada aos relatos e avaliações das professoras sobre o trabalho em desenvolvimento na escola; a outra parte correspondia à formação ministrada pelo professor da FEUSP sobre alguma área específica, como alfabetização na língua materna, ensino da geografia e da história para, conhecimentos específicos da matemática, e outros.

Ao final de 2008, equipe do LaPEF conjuntamente às professoras da escola propuseram ao CNPq o projeto intitulado "Aprender para ensinar e ensinar para que os alunos aprendam" (CNPq n ${ }^{\circ}$ 4712372008/6), o qual, uma vez aprovado, assegurou a continuidade da parceria.

A parceria perdurou oficialmente até 2010 com o funcionamento de seus fóruns formativos e com os contínuos registros de suas atividades. Ao longo dos três anos de parceria, o movimento foi intenso na escola, quando, a um só tempo, se geriam os encontros formativos e a filmagem das aulas ministradas por três das professoras que compunham o coletivo docente nos anos iniciais. Ao final de 2010, o grupo possuía uma grande quantidade de dados coletados, atualmente em processo de organização e de análise por pesquisadores da escola e do LaPEF.

Esses registros, bem como as frequentes avaliações, permitiram a sistematização e apresentação de trabalhos em congressos científicos nacionais e internacionais, tanto do campo do Ensino de Ciências como da Educação. Entre esses trabalhos, destacamos o painel apresentado no ENDIPE 2010 composto por três artigos, dois deles produzidos por professoras e pesquisadoras da escola (Azevedo et all, 2010; Bezerra et all, 2010) e o outro por pesquisadoras do LaPEF (Briccia \& Carvalho, 2010). Uma das intenções desse painel foi a de divulgar resultados em relação às contribuições da parceria para a escola, a partir da análise de declarações enunciadas pelas professoras, com reflexões que levaram a concluir que a parceria contribuiu sob aspectos estruturais e organizativos do ensino, formativos da docência e relativos à aprendizagem dos alunos em ciências. Para as autoras, a introdução de 
novos elementos teóricos à reflexão das professoras foi um dos elementos proporcionados pelos encontros formativos realizados na FEUSP e na unidade escolar. No que diz respeito à melhoria na organização do ensino, destaca-se a possibilidade de melhor sistematização e organização dos conteúdos em classe, não somente pelo acesso aos textos contidos nas sequências, mas pela viabilidade de impressão de novos materiais produzidos continuamente pelas professoras, propiciada pela aquisição de equipamentos de apoio (computador e impressoras) adquiridos com a verba advinda do projeto financiado pelo $\mathrm{CNPq}$.

A seguir, descrevemos o modo de organização do ensino e a estrutura das aulas de ciências das professoras envolvidas nos processos formativos referenciados, tanto no período em que ocorreu a parceria como após a sua finalização. Ainda que feita de modo breve, esta descrição pode levar a uma melhor compreensão da relação construída pelo grupo entre suas próprias propostas de como ensinar ciências e aquelas introduzidas em suas aulas pelas sequências organizadas e propostas pela equipe do LaPEF. Além do mais, devemos lembrar que a análise desta investigação é centrada no contexto da atividade docente em sala de aula, o que faz com que esta descrição se torne ainda mais importante.

\subsubsection{Organização geral do ensino de ciências e estrutura das aulas de ciências}

Como já foi dito antes, o modo geral de organização do ensino de ciências nos anos iniciais da EMEF Candido Portinari é circunscrito à realização das Atividades Investigativas de Ensino, configuradas como um conjunto de ações orientadas pela busca de solução do problema geral de ensino - como criar situações em que os estudantes, a um só tempo, se apropriem de significados em ciências, aprendam a se comunicarem pela linguagem oral e escrita, além de se tornarem leitores fluentes? Compreendemos a complexa dimensão do objetivo que encerra esse problema, o qual poderia ser também dimensionado se falássemos em levar os alunos a aprender a falar ciências ou a se alfabetizarem ou a se enculturarem cientificamente, a considerar a amplitude desses termos (Lemke, 1997, 1998; Sasseron \& Carvalho, 2008).

Veremos então, numa visão mais próxima e específica, o modo como esse processo é desenvolvido pelo grupo de professoras na escola. O ensino toma uma forma geral de organização logo na primeira semana do ano letivo quando o grupo docente se reúne para planejar objetivos, conteúdos e principais ações. No decorrer do ano, ao longo das reuniões pedagógicas e horários coletivos de estudos (JEIF), esse plano é revisitado, alguns problemas de ensino delimitados, e as ações, planejadas para resolvê-los, adequadas e replanejadas. 
Além do plano geral para o ciclo (05 anos), há as planificações elaboradas pelo grupo de professoras de cada ano, sempre de acordo aos objetivos gerais e metas pré-estabelecidos no plano geral. Esta organização engloba todas as áreas do ensino, pensadas de modo que se estabeleçam diálogos entre elas, cujos elos são construídos a partir dos objetivos e conteúdos. No caso dos anos iniciais, em que apenas uma professora responde pelo ensino em todas as áreas, essa integração é facilitada.

Em Ciências, esse modo geral de organização do ensino se estende ao trabalho de sala de aula, onde se constata a materialização de muitas das ações planejadas. Como o planejamento é coletivo, notam-se similaridades entre as aulas das professoras, variando de acordo com o estilo de cada uma. As aulas são pensadas a partir da orientação metodológica em construção nessa área, contando com o Laboratório de Ciências como um espaço adequado a qualquer atividade realizada com alunos em pequenos grupos, seja experimental ou não, ou com alunos organizados em um grande círculo, como as rodas de conversas, por exemplo. A autora deste estudo é a profissional responsável pela coordenação dos projetos organizados via esse espaço, dando apoio e orientação à organização e realização do ensino. O laboratório é uma extensão da sala de aula, onde se começa ou se continua determinada atividade.

Além do Laboratório de Ciências, as professoras contam com a Sala de Leitura, Sala de Artes e Laboratório de Informática, cujas atividades são organizadas e realizadas por especialistas. Muitos dos projetos em ciências são integrados aos projetos desenvolvidos nessas salas ambiente.

Esse modo geral de organização do ensino é estruturado no formato de módulos de ensino, orientados por uma temática geral, por um problema de ensino e objetivos específicos. Ao se pensar num módulo de ensino, delimita-se o problema de ensino específico e planificase uma sequência de ações a serem realizadas nos diferentes espaços. Essas ações são estruturadas em Atividades Investigativas de Aprendizagem, quantas forem necessárias para a resolução do problema de ensino.

O módulo de ensino é sempre introduzido por uma ação de sensibilização, cuja intenção é mobilizar as crianças para a temática a ser estudada. Muitas vezes, essas ações são organizadas com a integração de áreas, como artes e ciências, livros literários infantis e ciências, vídeos educativos, entre outras associações. Como exemplo, temos uma recriação do livro "Zoom"8 de autoria de Istvan Banyai, como um atividade que deu início a sequência "Os

\footnotetext{
${ }^{8}$ BANYAI, Istivan. Zoom. São Paulo: Brinque-book, 1997.
} 
caminhos da água" (caderno de aluno, $3^{\circ}$ ano, 2009). Outro exemplo é a leitura compartilhada do livro "Lolo Barnabé"9 de Eva Furnari realizada como abertura dos estudos no módulo “transformação de energia" (caderno de aluno, 4 ano, 2009).

Após a sensibilização, inicia-se a Atividade Investigativa de Aprendizagem propriamente dita com a proposição de um problema de aprendizagem, cuja solução exige um plano de ação feito por grupos de crianças. Esse problema é caracterizado como de aprendizagem por ter em sua base uma necessidade cognitiva referente ao significado que se objetiva construir, e por exigir a aquisição de formas gerais de ação em seu processo de resolução (Rubtsov, 1996). Essas formas gerais de ação se constituem como uma base teórica que dá sustentação e orientação ao conjunto de ações realizadas no processo de resolução do problema. O planejamento de ações requer determinado grau de consciência quanto aos elementos de aprendizagem introduzidos no processo.

Entre essas ações, destacam-se as de cunho experimental, por serem as mais frequentes e mais reconhecidas pelo coletivo docente como as que mais mobilizam as crianças para a apropriação do significado intrínseco ao conteúdo em estudo. Após a resolução do problema via experimentação ou por meio de outra estratégia de investigação, organiza-se uma roda de conversa para que se discutam os modos de ação postos em prática, bem como a elaboração teórica das crianças a respeito.

Após a roda de conversa, as crianças escrevem individualmente seus relatórios, compreendidos como narrativas espontâneas sempre recheadas com desenhos. Em seguida, introduz-se textos científicos elaborados previamente pelas professoras ou extraídos das sequências organizadas pelo LaPEF, ou retirados de outras fontes, como de algum periódico como a revista Ciência Hoje das Crianças ${ }^{10}$, do livro didático ${ }^{11}$ utilizado como apoio, ou ainda de algum site avaliado como seguro.

O módulo de ensino é finalizado com a implementação de ações que visam a rememoração do processo de aprendizagem, como por exemplo, a produção coletiva de mapas de conhecimentos, em que as crianças, após a rememoração oral, escrevem em curtas frases sobre o que aprenderam e afixam no painel organizado para esse fim.

Apesar de se ter um plano geral como base de orientação para o trabalho, nota-se que no âmbito da sala de aula outras ações são acrescentadas pelas professoras no decurso do

\footnotetext{
9 FURNARI, Eva. Lolo Barnabé. São Paulo: Editora Moderna, 2000.

${ }^{10}$ Publicação mensal do Instituto Ciência Hoje - Organização social de interesse público da SBPC.

11 NIGRO, R. G. \& CAMPOS, M. C. C. Vivência e Construção- Ciências - $1^{\circ}$ ao $5^{\circ}$ ano - Editora Ática.
} 
desenvolvimento, as quais são socializadas entre elas. É muito comum a ida de uma professora à sala de outra para sugerir ou solicitar ideias; como também é corriqueiro uma criança levar o caderno de uma professora a sala de outra para que uma veja o que a outra está fazendo; encontros rápidos no corredor entre duas ou mais professoras também são muito frequentes para fazerem o que elas próprias chamam de "trocar figurinhas". Esse movimento tem continuidade nos encontros diários coletivos, o que vai fortalecendo os laços colaborativos.

Ao que parece, as professoras constituíram um modo próprio de ação, o qual expressa a relação estabelecida por elas entre o trabalho preexistente na escola e ao que foi introduzido com a parceria. Uma visão geral sobre cadernos de alunos entre as tantas observações de aulas realizadas ao longo da coleta de dados, pode nos levar a uma compreensão melhor sobre essa relação. Constata-se que ao longo do ano letivo as professoras desenvolvem tanto atividades elaboradas por elas próprias como aquelas introduzidas pelo LaPEF. São encontradas também diferentes atividades combinadas às que compõem as sequências do LaPEF, como verificamos a intitulada "o problema da coluna de água em uma garrafa pet", intercaladas às que estruturam a sequência "os caminhos da água" (caderno de aluno, $3^{\circ}$ ano, 2009). Outro exemplo é a sequência "transformações de energia em um aquecedor solar" elaborada pelas professoras e acrescida ao módulo "transformações de energia" originalmente organizado pelo LaPEF (caderno de aluno, $4^{\circ}$ ano, 2011).

Conclui-se que os processos formativos referenciados estão integrados a esse modo geral de organização de ensino, tanto aquele desencadeado pelo Laboratório de Ciências, como o proposto e praticado pela equipe do LaPEF nos dois fóruns formativos. Ambos os processos parecem influenciar o processo de planejamento e realização do ensino.

Para que possamos melhor visualizar o movimento geral de organização do ensino de ciências nos anos iniciais, vamos representá-lo tal como sugere Engestrom (1999), em um Sistema Coletivo de Atividade: 
Figura 05 - Movimento geral de organização do ensino de ciências nos anos iniciais em um sistema coletivo de atividade.

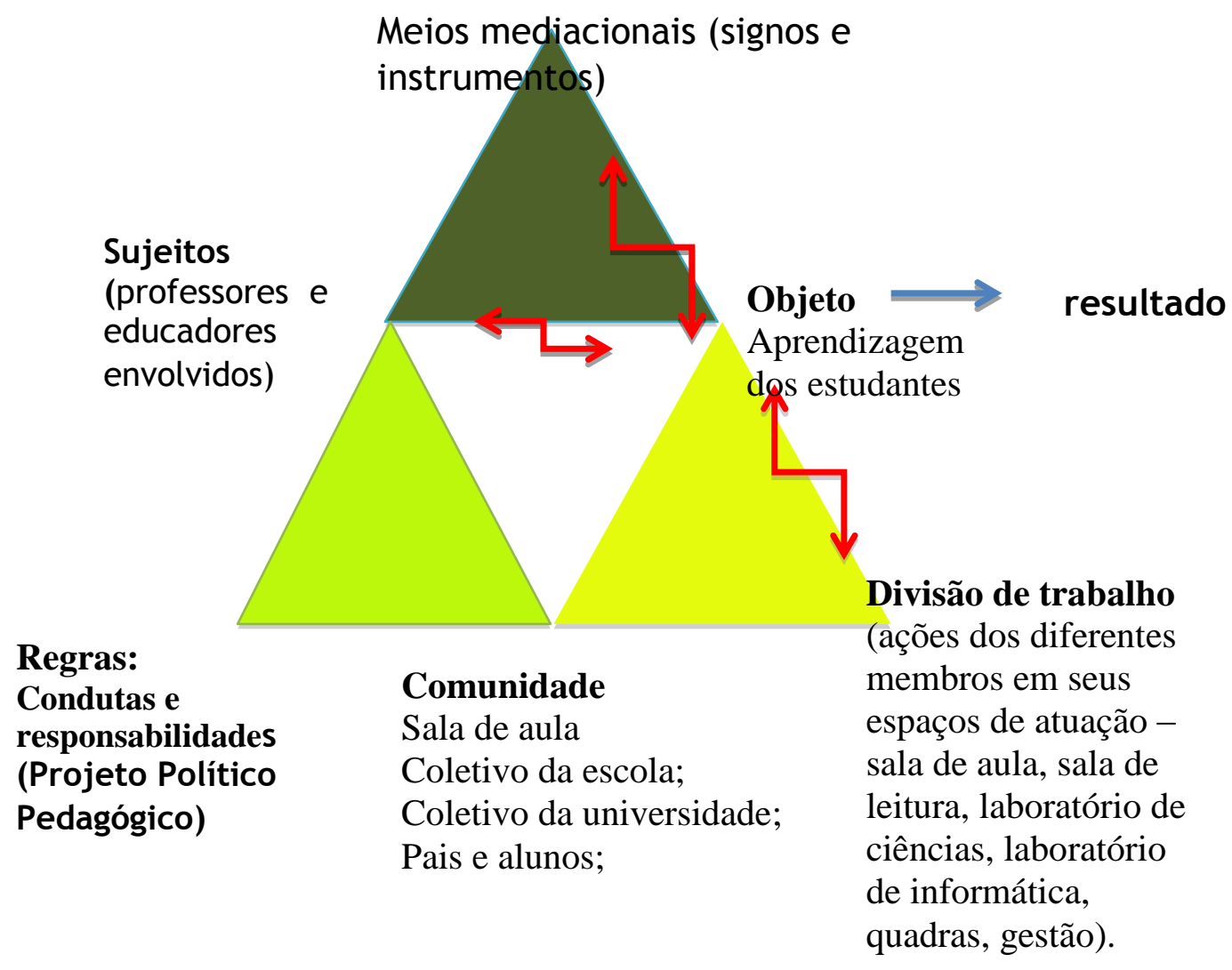

O sistema coletivo de atividade permite visualizar as inúmeras inter-relações, bem como o papel e a ação dos sujeitos envolvidos. É possível inferir também sobre a origem das fontes influenciadoras sobre o modo e o conteúdo sob os quais as professoras estruturam suas aulas como: suas próprias experiências pessoais, formativas e culturais; o grupo colaborativo da escola (planejamentos, avaliações e estudos realizados no horário coletivo de estudo); o grupo colaborativo da universidade, cujas influências advêm do processo formativo e do conteúdo das sequências elaboradas pelo LaPEF; Projeto Político Pedagógico da escola; orientações curriculares oficiais; respostas dos alunos aos modos de mediação docente; participação dos pais; e de fontes de estudos e pesquisas (periódicos, livros didáticos, sites da internet, etc.). 
É importante lembrar as contradições imanentes às relações estabelecidas no âmbito desse sistema coletivo de atividade, representadas pelas flechas, oriundas das opiniões convergentes e divergentes que emanam das tantas vozes que o compõe. Nem é possível esquecer do que já foi dito por Engestrom (1999) em relação à importância dessas contradições no processo das transformações qualitativas passiveis de ocorrerem nos diferentes ciclos que movimentam o Sistema em sua totalidade. São transformações decorrentes das mudanças nos diferentes aspectos objetivos e subjetivos que impactam os planos físicos e culturais sobre os quais se assentam as relações de ensino e de aprendizagem na abrangência do ensino de ciências nos anos iniciais. Vale destacar ainda que os processos de aprendizagem e desenvolvimento profissional dos sujeitos estão correlacionados às transformações qualitativas dos ciclos que compõe o sistema como um todo.

Em síntese, esse ensino é mobilizado pela necessidade de proporcionar a aprendizagem em ciências. Tal necessidade, por sua vez, gera os motivos que fazem esse ensino acontecer com características próprias relacionadas ao modo como cada professora busca praticá-lo em sua sala de aula.

É, exatamente, nessa busca constante em ensinar ciências de modo que as crianças aprendam que esta pesquisa é gestada e desenvolvida. Seus motivos emergem das relações interpessoais e profissionais que mobilizam as tantas ações constitutivas do modo como as professoras organizam e realizam esse ensino. Ao participarmos diretamente desse processo, nos sensibilizamos e nos motivamos pelo anseio de compreender a relação aprendizagem docente e desenvolvimento profissional dessas professoras no processo de realização de sua atividade docente.

\subsection{Metodologia da pesquisa}

Em coerência com a teoria histórico-cultural, nos aproximamos do materialismo histórico e dialético na busca de fundamentos para compor um método de análise nesta investigação. Essa aproximação decorre da centralidade dessa base epistemológica nas dimensões culturais, históricas e semióticas expressas no modo como a formação humana é aqui concebida, tal qual foi abordada no primeiro capítulo.

Essa centralidade também está na base dos estudos de Vigotski sobre as funções psicológicas superiores e na construção de seu método de análise. Esse pensador estabelece 
relação direta entre o elemento chave do seu método com os elementos centrais do materialismo histórico dialético. Na passagem abaixo, extraída de uma de suas obras, ele se apoia em Engels ${ }^{12}$ para contrastar as abordagens naturalística e dialética para a formação e desenvolvimento humano. Em suas palavras:

Segundo Engels, o naturalismo na análise histórica manifesta-se pela suposição de que somente a natureza afeta os seres humanos e de que somente as condições naturais são os determinantes do desenvolvimento histórico. A abordagem dialética, admitindo a influência da natureza sobre o homem, afirma que o homem, por sua vez, age sobre a natureza e cria, através das mudanças nela provocadas, novas condições naturais para sua existência (Vigotski, 2010, p. 62).

Entretanto, embora Vigotski construa sua obra inteiramente coerente com a abordagem dialética da análise da história humana, ele não concorda com a aplicação direta do materialismo dialético às investigações no campo da psicologia. Segundo esse autor, do mesmo modo como se criou o materialismo histórico como método decorrente das "leis abstratas do materialismo dialético", para interpretar o grupo de fenômenos de que se ocupa a história, torna-se "igualmente necessária" a criação de teorias intermediárias nos campos específicos de cada área da ciência, cada uma ocupada em explicar os seus próprios fenômenos (Vigotski, 2004, p. 392).

Com essa posição e com os fundamentos do método dialético, Vigotski voltou-se à criação do "materialismo psicológico", teoria intermediária mediadora de suas análises no campo da psicologia, fundamentada em alguns princípios metodológicos e no método de análise por unidades.

De nossa parte, encontramos nos princípios metodológicos construídos por Vigotski, bem como em seu método de análise por unidades, fundamentos para elaborar as orientações metodológicas, sob as quais desenvolvemos esta pesquisa. Essa escolha foi orientada, sobretudo pela relação que estabelecemos entre o objeto de estudo desta investigação - a relação entre motivo e sentidos docente com a aprendizagem e desenvolvimento profissional docente - com os princípios elaborados por Vigotski para o estudo do desenvolvimento das funções psicológicas superiores. Esses princípios estão explicitados a seguir:

(1) uma análise do processo em oposição a uma análise do objeto; (2) uma análise que revela as relações dinâmicas ou causais, reais, em oposição à enumeração das características externas de um processo, isto é, uma análise

\footnotetext{
${ }^{12}$ Teórico revolucionário alemão que junto com Karl Marx elaborou as teorias que compõem o materialismo histórico dialético. Engels (1820-1895); Karl Marx (1818-1883).
} 
explicativa e não descritiva; e (3) uma análise do desenvolvimento que reconstrói todos os pontos e faz retornar à origem o desenvolvimento de uma determinada estrutura (Vigotski, 2010, p. 69).

O desenvolvimento profissional docente, além de compreender um longo período, engloba processos como a formação do pensamento teórico do professor, bem como a formação de sua consciência e personalidade relacionadas à atividade laboral. Portanto, para analisar tal fenômeno buscamos realizar uma análise dinâmica e processual, de modo que seja possível retornar aos seus estágios iniciais, aqui viabilizado mediante entrevistas semiestruturadas com consultas sobre aspectos importantes da formação escolar e profissional de cada sujeito (Vigotski, 2010).

A explicação é privilegiada em detrimento da descrição, posto que se pretenda ir além das características perceptíveis aos olhos, à busca da essência do objeto de estudo. O propósito não é apenas identificar ou descrever as situações de aprendizagem supostamente inerentes aos modos de mediação docente, mas discuti-las à luz das relações que medeiam a atividade em curso, as quais não se manifestam externamente, mas sim internamente.

Para Vigotski, a explicação visa a análise genotípica, a qual difere da análise fenotípica por explicar o fenômeno com base em sua gênese ou origem e não apenas como ela se apresenta em sua aparência. Vigotski ilustra essa discussão com um exemplo no campo biológico, o qual contribui com uma melhor compreensão da relação estabelecida entre aparência e essência:

Uma baleia, do ponto de vista de sua aparência externa, situa-se mais próxima dos peixes do que dos mamíferos; mas, quanto à sua natureza biológica está mais próxima de uma vaca ou de um veado do que de uma barracuda ou de um tubarão (2010, p. 64-65).

Ou seja, sem a gênese do conceito ou sem a natureza do fenômeno, não se estaria realizando uma análise científica e, em nenhuma circunstância, se chegaria à essência de determinado fenômeno, e nem se poria “(...) a nu as diferenças internas escondidas pelas similaridades externas" (ibidem, p. 65). A essência de um fenômeno está, exatamente, em sua natureza ou origem, escondida nas relações intrínsecas ao seu movimento processual.

No entanto, diferir as manifestações externas das internas consiste em uma tarefa de alta complexidade, a qual, para ser executada, exige um olhar atento munido de elementos teóricos. Por exemplo, se no âmbito do movimento dialógico discursivo em sala de aula, um 
pesquisador analisasse uma pergunta proferida por uma professora sem estabelecer vínculos entre essa pergunta e as enunciações dos alunos, ele estaria incorrendo em uma descrição ou análise fenotípica, uma vez que teria considerado apenas a manifestação física ou externa do fenômeno, se esquivando de sua essência ou manifestações internas imanentes à ressonância dessa pergunta nas vozes dos alunos. Isto é, a explicação e gênese desse fenômeno não estão isoladas na pergunta da professora, mas no conceito de enunciação, prenhe de mediações intrínsecas à conversação entre sujeitos, em que a fala de um é o espelho da fala de outro.

Na verdade, a apreensão da essência de um fenômeno consiste na própria atividade científica, isto é, na própria produção do conhecimento, somente possível mediante um pensamento teórico capaz de abrir caminhos para se superar o imediatismo das manifestações externas e se atingir a essência, oculta em sua gênese ou natureza. Baseados em Kosik (2002), Rigon; Asbahr \& Moretti (2010) reiteram esse princípio, ao afirmarem que atingir a essência de um fenômeno, significa alcançar a sua totalidade, somente possível por meio da atividade do pensamento.

O terceiro princípio anunciado por Vigotski (2010), considerado por ele como o requisito básico do método dialético, se refere à necessidade de estudar historicamente um fenômeno, o apreendendo em movimento, em pleno processo de mudanças. Para esse autor, esse estudo não é um princípio complementar à análise, mas a sua verdadeira base. Alerta, porém, que privilegiar o exame da dimensão histórica do fenômeno não significa "estudar eventos passados, mas sim o curso de transformação que engloba o presente, as condições passadas e aquilo que o presente tem de projeção do futuro" (Góes, 2000, p. 13). Portanto, a atenção às mudanças qualitativas no processo de vivência profissional das professoras, no sentido retrospectivo e prospectivo de seu desenvolvimento profissional, assume relevante importância no processo de análise posto em prática neste trabalho.

Por fim, apresentamos o método de análise por unidades. Em contraposição à psicologia tradicional, Vigotski propõe que um fenômeno, para ser analisado, deve ser decomposto em unidades, e não em partes isoladas, pois o somatório dessas partes não resultaria em sua totalidade. Diferente das partes ou elementos isolados, a unidade consiste na menor parte que "possui todas as propriedades do todo que são inerentes ao todo e, concomitantemente, são partes vivas e indecomponíveis dessa unidade” (Vigotski, p.08, 2009b).

A molécula da água, como unidade da totalidade água, é um dos exemplos dados por Vigotski (2009b). Segundo esse autor, se alguém tentasse explicar as propriedades da água, 
decompondo a sua molécula em seus elementos químicos, se surpreenderia, pois nem o hidrogênio e nem o oxigênio apresentariam propriedades comuns às da água. Portanto, a molécula da água, ao contrário dos elementos que a compõe, é a menor parte indecomponível da água e contém em si todas as propriedades desse todo.

Esse método de análise por unidades, também denominado por Vigotski (2004) de "método inverso" ou "método indireto", é fundamentado com base no movimento originalmente explicitado por Karl Marx (1985) como o método de apreensão do real via ascensão do abstrato ao concreto. O método inverso corresponde ao movimento que possibilita estudar a essência de determinado fenômeno mediante a análise de formas mais desenvolvidas desse mesmo fenômeno. As formas mais desenvolvidas seriam aquelas que mostrariam o caminho para se compreender as formas menos desenvolvidas e elevá-las ao caráter de mais desenvolvidas.

Em um processo de análise, a forma mais desenvolvida seria a própria unidade de análise, denominada por Marx de abstrato ou abstração, entendida como a mediação teórica que possibilita ao pesquisador a apreensão da essência do fenômeno por meio de suas formas menos desenvolvidas. Essa apreensão, mediatizada pelo pensamento teórico, é o ponto de partida da análise, a qual tem como ponto de chegada o concreto, qual seja, a concretude dimensionada no alcance do objeto e do objetivo da investigação. Duarte (2000, p. 84) esclarece o que acabamos de dizer:

Por sua vez, a essência do fenômeno na sua forma mais desenvolvida não se
apresenta ao pesquisador de forma imediata, mas sim de maneira
mediatizada e essa mediação é realizada pelo processo de análise, o qual
trabalha com abstrações. Trata-se do método dialético de apropriação do
concreto pelo pensamento científico através da mediação do abstrato. A
análise seria um momento do processo de conhecimento, necessário à
compreensão da realidade investigada em seu todo concreto.

Em síntese, a abstração ou forma mais desenvolvida, ou ainda, unidade de análise conduz o pesquisador desde o ponto de partida - a apreensão do real, até o ponto de chegada - o concreto. Portanto, a unidade ou menor parte do fenômeno que conserva suas propriedades, é o elemento mediatizador do processo de análise, o qual conduz o pesquisador ao caminho inverso, ao retorno ao real, agora visto não mais como uma forma menos desenvolvida, mas como concreto apropriado e reconstruído via mediação teórica e dimensionado como uma síntese do processo investigativo, cuja essência consiste na totalidade do objeto. Esse movimento em que se vai da apropriação do real, por meio da 
unidade abstrata, para em seguida, retornar ou ascender-se ao concreto, sintetiza o processo de análise e justifica a sua denominação de método inverso.

Por fim, enfatizamos o lugar da teoria em todo o processo da investigação, desde o primeiro contato com a realidade contextual às considerações finais. Sem a mediação teórica, não há como formular a pergunta, uma vez que esta contém em sua essência os elementos teóricos que guiarão o pesquisador, não apenas para a delimitação dos procedimentos metodológicos, mas sobretudo para a precisão sobre a unidade de análise. Como afirma González Rey (2002), a pergunta conduz os diálogos que se sucedem na pesquisa, seja com os sujeitos ou com o seu objeto de investigação, por meio dos quais garantimos a qualidade do conhecimento produzido; sem o aporte teórico não é possível delimitar a unidade de análise ou mediação teórica que nos possibilita chegar à essência do fenômeno.

Passamos agora a mais um passo no movimento de apreensão do fenômeno em análise nesta pesquisa. No tópico anterior apresentamos, de modo geral e descritivo, algumas das particularidades de seu contexto. A seguir, trataremos de apresentar mais amiúde os demais passos metodológicos.

\subsubsection{O problema, a unidade de análise e objeto da investigação}

Como já adiantamos, o fenômeno em estudo é o processo de desenvolvimento profissional docente, cujo objeto - a relação entre motivos e sentidos docente com a aprendizagem e desenvolvimento profissional, está sendo apreendido no movimento dialógico discursivo subjacente à atividade docente em sala de aula e, por conseguinte, com centralidade sobre as questões referentes à linguagem, sendo essa concebida como signo/instrumento mais importante na mediação das interações sociais e do processo de comunicação e de aprendizagem.

Sem desmerecer as diferentes ações que compõem o trabalho docente (ações realizadas fora da sala de aula, como o planejamento e encontros formativos, por exemplo), escolhemos a sala de aula como contexto de análise, por ser o lugar, por excelência, onde o ensino e a aprendizagem se articulam e se realizam; o lugar de onde provêm as necessidades, motivos e sentidos da atividade do professor, bem como de sua aprendizagem e desenvolvimento; e o lugar, onde essas necessidades, motivos e sentidos se realizam ou se objetivam. Nesse sentido, podemos supor a sala de aula, para o professor, como um lugar de desenvolvimento profissional. 
$\mathrm{Na}$ abrangência do movimento dialógico discursivo que rege a conversação em sala de aula, a linguagem e, especialmente, as palavras nascem da necessidade de comunicação, da necessidade de realizar o motivo e objetivo da atividade em desenvolvimento: para o professor, ensinar ciências de modo que os estudantes se apropriem dos significados historicamente e culturalmente produzidos; e para alunos, a apropriação desses significados.

Ainda mais: essa linguagem não se realiza por si só, mas ancora-se e integra-se no professor e na grande variedade de ações que compõem a atividade docente. Ou seja, as palavras não subsistem sem as ações; do mesmo modo, as ações necessitam das palavras para se materializarem. Com isso queremos dizer que linguagem e ações são elementos que se integram ao professor para compor a mediação discursiva docente, delimitada como unidade de análise desta investigação. Nesse sentido, supomos que a mediação discursiva docente guarda os elementos que compõem a totalidade das relações mediadas em sala de aula que dinamizam e proporcionam o desenvolvimento profissional docente no âmbito desse nível de atuação.

Nessa abrangência teórica, mediação discursiva docente tem em si engendrado o conceito de ação mediada, tal qual é definido por Werstch. No processo contínuo de realização de sua atividade pedagógica, o professor atua com a linguagem/ação, cuja relação ocorre de modo tão imbrincado que a dissociação de um desses elementos acusaria o fim da ação: a ação mediada discursiva docente não se realizaria na ausência do professor ou da linguagem/ação, o que corresponde à tensão irredutível existente entre o agente (professor) e o modo de mediação, própria de toda ação mediada (Werstch, 1999).

Como unidade de análise, a mediação discursiva docente assume o papel da forma mais desenvolvida do desenvolvimento profissional docente em sala de aula, ou seja, assume o papel de mediação teórica ou abstração, por meio da qual buscamos alcançar a essência de nosso objeto - a relação aprendizagem docente e desenvolvimento profissional gestada no espaço criado pelo processo mediacional discursivo em sala de aula.

O alcance desse objeto trilha pela discussão da seguinte questão: o que a mediação discursiva docente pode mostrar sobre o trabalho docente em sala de aula e desenvolvimento profissional de professores dos anos iniciais que ensinam ciências sob orientação investigativa?

Com este problema, enfatizamos o papel mediador da unidade de análise. No desempenho desse papel, a mediação discursiva docente nos fornece subsídios para refletir 
sobre a relação passível de se estabelecer entre necessidades, motivos e sentidos de aprendizagem docente emergentes da atividade do professor com o seu desenvolvimento profissional. Talvez o sentido dessa aprendizagem esteja inter-relacionado com o sentido que o professor atribui ao seu trabalho; ou quem sabe, o sentido da aprendizagem emerja das possibilidades e limites inerentes à mediação discursiva docente e aos espaços que se abrem no amplo espectro da luta pela constituição da docência como práxis ou atividade humana e humanizadora.

Dito de outro modo, a relação motivos, sentidos de aprendizagem e desenvolvimento profissional encontra sentido de existência no próprio germe da docência como atividade humana, qual seja, na mediação discursiva docente: o professor, ao atuar intencionalmente e deliberadamente, via combinação signo/instrumento, para transformar o seu objeto de trabalho, também cria condições para transformar a sua natureza humana, com possibilidades de mudanças qualitativas em suas funções psicológicas. O professor, ao construir contextos de aprendizagem em que seus alunos se apropriem de significados, forja necessidades, motivos e sentidos de sua aprendizagem, os quais podem se materializar em situações de aprendizagem potencialmente incidentes sobre funções psicológicas em processo de amadurecimento contidas em sua Zona de Desenvolvimento Proximal e, assim, podem se converter em seu próprio desenvolvimento profissional.

Outro aspecto a esclarecer é o fato de nos referirmos reiteradas vezes sobre motivos e sentidos imanentes às situações de aprendizagem. Ao nos apoiarmos em Leontiev e fazermos tais referências, estamos tão-somente criando nexos entre esses complexos conceitos - o motor da atividade e o seu sentido para o professor - com a função social ou significação social da docência. A nosso ver, motivos e sentidos de aprendizagem se formam nesta relação, no espaço forjado pela mediação discursiva docente, onde se reflete a relação de contradição existente entre alienação e aprendizagem/desenvolvimento profissional docente. O conteúdo do motivo/sentido que o professor atribui à sua atividade confere ao conjunto de suas mediações discursivas, o conteúdo dos diferentes modos de ação/linguagem que intermedeiam ou se posicionam entre o professor, o conhecimento e a aprendizagem do aluno. Não é demais reiterar que o sentido que o professor atribui à sua atividade, oriundos de seus motivos, pode se constituir como fator de influência tanto sobre a construção de sentidos/aprendizagem pelos alunos como sobre sua atuação em sala de aula, ora impelindo, ora limitando o seu próprio processo de trabalho, em consequência, o seu próprio processo de desenvolvimento profissional. 
O alcance da concretude desta investigação poderá nos aproximar das necessidades formativas e dos motivos que movem e conduzem a atuação docente em sala de aula, o que nos possibilitará fornecer subsídios e indicar caminhos que contribuam com as discussões teóricas e metodológicas inseridas no campo da formação de professores. Tal pretensão está relacionada ao pressuposto básico desta investigação, o de que os processos de formação contínua devem ser pensados à luz das necessidades e motivos docentes, os quais podem se converter em situações de aprendizagem e, como tal, impulsionarem o desenvolvimento profissional.

Outra intenção deste estudo é a ampliação do significado de desenvolvimento profissional docente, com contribuições que possibilitem uma melhor compreensão sobre quais funções psicológicas superiores do professor são suscetíveis de transformação no âmbito do exercício de sua docência.

\subsubsection{Sujeitos da pesquisa e os procedimentos para coleta de dados}

O quadro de sujeitos é composto pelas professoras do Ensino Fundamental I, participantes do coletivo em processo de formação, tanto aquelas que estão nas salas de aula, como as que ocupam cargos de coordenação ou direção ou que exercem atividade de orientação em salas ambiente, com atendimento aos alunos desse ciclo de ensino.

Quadro I - Sujeitos da pesquisa

\begin{tabular}{|c|c|c|c|c|c|}
\hline Professora & Idade & $\begin{array}{l}\text { Tempo de } \\
\text { Magistério }\end{array}$ & $\begin{array}{c}\text { Início } \\
\text { na escola }\end{array}$ & $\begin{array}{c}\text { Formação } \\
\text { inicial e pós- } \\
\text { graduação }\end{array}$ & Função em 2008 \\
\hline Lílian & 47 & 23 & 1989 & $\begin{array}{c}\text { Sociologia } \\
\text { Mestrado e } \\
\text { Doutorado em } \\
\text { Educação }\end{array}$ & SAP \\
\hline Rose & 41 & 14 & 2001 & Pedagogia & Profa $4^{\mathrm{a}}$ série \\
\hline Mara & 38 & 08 & 2001 & Pedagogia & Profa $2^{\circ}$ e $4^{\circ}$ série \\
\hline Áurea & 31 & 12 & 2001 & Pedagogia & Profa de $1^{\mathrm{a}}$ série \\
\hline Sofia & 39 & 20 & 1989 & $\begin{array}{c}\text { Pedagogia e } \\
\text { Direito }\end{array}$ & $\operatorname{Prof}^{\mathrm{a}} 4^{\mathrm{a}}$ série \\
\hline Verônica & 37 & 18 & 2007 & $\begin{array}{l}\text { Magistério e } \\
\text { Letras }\end{array}$ & Profa $4^{\mathrm{a}}$ série \\
\hline
\end{tabular}




\begin{tabular}{|c|c|c|c|c|c|}
\hline Carla & 46 & 25 & 1986 & Pedagogia & $\begin{array}{l}\text { Orientadora do } \\
\text { Laboratório de } \\
\text { Informática }\end{array}$ \\
\hline Olga & 43 & 23 & 2007 & $\begin{array}{c}\text { Pedagogia e } \\
\text { Biblioteconomia }\end{array}$ & Profa $4^{\mathrm{a}}$ série \\
\hline Violeta & 42 & 22 & 1991 & Pedagogia & Prof $^{\mathrm{a}} 1^{\mathrm{a}}$ série \\
\hline Laura & 43 & 20 & 1991 & Pedagogia & $\operatorname{Prof}^{a} 3^{a}$ série \\
\hline Mônica & 47 & 19 & 1999 & Pedagogia & Prof $^{a} 2^{a}$ e $4^{a}$ série \\
\hline Bianca & 44 & 22 & 1991 & $\begin{array}{l}\text { Serviço Social, } \\
\text { Psicologia e } \\
\text { Pedagogia }\end{array}$ & $\begin{array}{l}\text { Auxiliar de } \\
\text { Direção }\end{array}$ \\
\hline Iris & 45 & 14 & 1997 & Pedagogia & Prof $^{a} 3^{a}$ série \\
\hline Soraia & 45 & 25 & 1983 & $\begin{array}{l}\text { Música, Artes e } \\
\text { Pedagogia }\end{array}$ & $\begin{array}{l}\text { Orientadora de } \\
\text { Sala de Leitura }\end{array}$ \\
\hline Nara/Coord & 47 & 22 & 1993 & $\begin{array}{l}\text { Ciências } \\
\text { Biológicas }\end{array}$ & $\begin{array}{l}\text { Coordenadora do } \\
\text { Laboratório de } \\
\text { Ciências }\end{array}$ \\
\hline Andreza & 35 & 15 & 2000 & Pedagogia & $\operatorname{Prof}^{\mathrm{a}} 3^{\mathrm{a}}$ série \\
\hline Adriana & 38 & 19 & 1990 & $\begin{array}{c}\text { Pedagogia e } \\
\text { Geografia }\end{array}$ & $\operatorname{Prof}^{\mathrm{a}} 2^{\mathrm{a}}$ série \\
\hline
\end{tabular}

Fonte: informações organizadas pela autora.

As professoras Lílian, Verônica, Andreza, Mara, Sofia e Olga mantiveram um grau maior de envolvimento com a pesquisa, pois, além de participarem do coletivo formativo, cederam entrevistas e aceitaram que suas aulas fossem filmadas. Entre essas professoras, analisamos o desenvolvimento profissional de apenas uma, o da professora Verônica, por considerarmos suficiente para a o propósito ao qual nos enveredamos. A escolha pela professora Verônica se deu em decorrência do seu grau de envolvimento e participação com os projetos da escola e, sobretudo, por se caracterizar como uma professora que reconhece suas dificuldades e/ou necessidades e se coloca em busca de soluções.

A coleta de dados ocorreu mais sistematicamente nos anos de 2008, 2009 e 2010. As filmagens e entrevistas realizadas em 2011 foram esporádicas e pontuais. Apresentamos em anexo um quadro (apêndice I) com a organização geral dos dados, o qual possibilita uma primeira ideia sobre a totalidade dos dados coletados. Mais adiante apresentaremos o quadro de dados selecionados e organizados para a análise.

Os principais instrumentos de coleta dos dados foram a videogravação, entrevistas semiestruturadas e a observação participante. Pelo fato de focalizarmos a atuação docente em sala de aula, a videogravação ocupa lugar de destaque, por ser esse recurso considerado como 
adequado para a captura de aspectos aliados ao áudio, como "expressões corporais, faciais e verbais" presentes na imagem em movimento (Garcez, Duarte \& Eisenberg, 2011, p. 251). Para Carvalho (2006), a filmagem de aulas tem se mostrado como uma técnica produtiva para as pesquisas sobre os processos de ensino aprendizagem, seja com enfoque sobre a formação de professores, seja sobre a aprendizagem dos alunos.

A observação contínua e participante também tem o seu lugar nesta pesquisa, pois muito contribuiu não apenas para a coleta em si, mas para a familiaridade com os dados e com reconhecimento do objeto de pesquisa. A atuação profissional da pesquisadora na escola, bem como a relação de confiança estabelecida entre ela e o grupo de professoras, propiciaram o seu contato direto e permanente com o fenômeno da investigação, por sua vez, favorável, sobretudo à observação contínua das diferentes manifestações que ocorrem naturalmente no cotidiano do exercício profissional docente.

As entrevistas semiestruturadas, embora realizadas em segundo plano, nos aproximaram da história de vida dos sujeitos, importante para traçarmos a gênese do objeto em estudo.

\subsubsection{A pesquisa como um estudo de caso com proximidades com a análise microgenética}

Algumas singularidades desta pesquisa nos levam a caracterizá-la como um estudo de caso, com destaque para sua inserção em uma determinada escola, seu apoio sobre um processo formativo com características peculiares, sua centralidade sobre certa área e nível de ensino e sua análise focalizada em um fenômeno específico. Como em um estudo de caso, essas particularidades são interpretadas no próprio contexto em que emergem (Lüdke \& André, 1984).

No que diz respeito ao processo de análise, estabelecemos relações de proximidades com a análise microgenética, cuja comparação é feita com princípios dessa abordagem metodológica apresentados em diferentes estudos entre os quais destacamos aqueles realizados por (Werstch, 1985; Meira, 1994; Góes, 2000; Barboza e Zanella, 2005).

Segundo Góes, a análise microgenética guarda coerência com os princípios metodológicos da teoria histórico-cultural para interpretação dos processos humanos. De modo geral, essa abordagem metodológica se ocupa da análise minuciosa de um processo, 
com atenção centrada em detalhes manifestados em recortes de episódios ou sequências de falas. Essa orientação advém do estudo sobre o plano genético denominado por Vigotski de microgênese, entendido como uma entrada para o estudo do desenvolvimento, por meio do qual se busca captar a construção de singularidades de cada sujeito e de cada processo analisado, com destaque para a sua gênese ou genética e suas mudanças. Como afirma Góes (2000, p. 15), a análise é genética “(...) no sentido de ser histórica”, “(...) por buscar relacionar os eventos singulares com outros planos da cultura, das práticas sociais, dos discursos circulantes, das esferas institucionais”. Como bem lembra Meira (1994), a análise detalhada desses eventos e das ações, coerente com essa abordagem metodológica, não pode perder de vista o significado da atividade, na qual tais eventos e ações se inserem.

Outro aspecto a ressaltar é que tanto a ênfase na gênese do processo como a consideração sobre o objetivo/significação da atividade, distingue a análise microgenética da análise microetnográfica. Nesta última, o pesquisador se volta para os microeventos de um fenômeno, sem necessariamente tomá-lo em movimento ou em seu processo histórico.

Vale esclarecer que a ênfase da análise microgenética nos detalhes de um processo não significa privilegiar elementos isolados em detrimento do recorte do fenômeno em unidades de análise. A esse respeito, Góes é contundente ao se posicionar, tal qual Vigotski, contrária ao "elementarismo" ou "privilegiamento de elementos isolados" (Góes 2000, p, 28, grifos no texto original), e a favor do método de análise por unidades, o qual já foi discutido acima.

Uma das grandes contribuições do trabalho de Meira (1994, p. 62) é a indicação de estratégias para a organização e análise de dados videogravados, característica da abordagem microgenética. Segundo esse autor, o pesquisador deve estar atento aos seguintes passos:

(1) assistir por completo e sem interrupções tantos vídeos quanto possível, realizando anotações preliminares sobre eventos associados ao problema de pesquisa; esta tarefa permite uma familiarização com os dados e a elaboração de uma caracterização geral da atividade; (2) produzir um "índice de eventos", que pode ser elaborado paralelamente à atividade descrita no item 1; este índice permitirá ao investigador um acesso mais rápido a segmentos específicos dos vídeos; (3) através do índice, identificar os eventos relacionados ao problema de pesquisa; esta fase inicia o trabalho interpretativo mais rigoroso (...); (4) transcrever literalmente os eventos selecionados, com o maior número possível de detalhes; a transcrição não deve substituir o vídeo, mas servirá como apoio à análise minuciosa do mesmo; (5) assistir persistente e repetidamente este segmento (ou episódios), apoiado pela análise exaustiva das transcrições, a fim de gerar interpretações plausíveis dos micro processos envolvidos na atividade; é importante lembrar que não há limites para quanto tempo o investigador deve deter-se 
em episódios específicos, pois o objetivo é construir uma caracterização densa sobre a atividade investigada, (6) ao divulgar resultados, apresentar interpretações ilustradas por exemplo prototípicos colhidos diretamente dos vídeos e transcrições, permitindo que o leitor possa compreender os argumentos e princípios teóricos sugeridos pelo investigador e/ou construir interpretações alternativas.

Essas indicações são valiosas para nossa pesquisa, pois grande parte dos dados são extraídos de transcrições de vídeos e organizados em episódios de ensino. Apenas enfatizamos que o referencial orientador para a seleção dos eventos e segmentos que compõem os episódios de ensino é realmente o problema de pesquisa, pois, em nosso caso, ao indagarmos sobre o que a mediação discursiva docente revela sobre o trabalho docente e desenvolvimento profissional de professores dos anos iniciais que ensinam ciências sob orientação investigativa, estamos exatamente elegendo como núcleo da pesquisa o seu objeto e a unidade que mediará a análise.

Portanto, a relação motivos e sentidos docentes, desenvolvimento profissional e a mediação discursiva constituem o núcleo do problema, eleito como elemento guia na construção do instrumento de análise, bem como na seleção e organização dos dados para análise. Esse é o assunto pautado no próximo capítulo. 


\title{
Capítulo IV - A pesquisa: construção do processo de análise
}

\author{
Privilegiar o exame da dimensão histórica do \\ fenômeno não significa "estudar eventos \\ passados, mas sim o curso de transformação que \\ engloba o presente, as condições passadas e \\ aquilo que o presente tem de projeção do \\ futuro" \\ Maria Cecília Góes
}

\subsection{Procedimentos de análise}

O instrumento de análise cumpre a função de nos guiar na busca das respostas para a questão que orienta a investigação - o que a mediação discursiva docente pode mostrar sobre o trabalho docente em sala de aula e o desenvolvimento profissional de professores dos anos iniciais que ensinam ciências sob orientação investigativa.

Os princípios para construção desse instrumento estão implícitos na essência dos elementos que se integram para compor a mediação discursiva docente, isto é, na atuação do professor com a ação e linguagem. O ponto de partida é a ideia de que a aula é composta pela articulação da atividade de ensino com a atividade de aprendizagem, em que o professor por meio de suas mediações discursivas, concebidas como um complexo de ações/enunciações mediadas, cada uma com seu objetivo imediato, busca cumprir o objetivo da atividade, o de criar oportunidades de aprendizagem para seus alunos.

A configuração da mediação discursiva docente é um passo importante no processo de análise, o qual nos aproxima do fenômeno em estudo. O reconhecimento dos diferentes modos de mediação docente nos fará transcender das manifestações externas à essência do objeto de análise. Esta configuração é orientada por dois eixos teóricos, delimitados com base no referencial teórico sobre a atuação docente e no processo de comunicação em aulas de ciências. Estes dois eixos são: padrões de diálogos e padrões temáticos.

O eixo padrões de diálogo reúne elementos condizentes com as cadeias de enunciações, por sua vez, caracterizadas como cadeias abertas e fechadas. Chamamos de cadeias fechadas aquelas compostas por diálogos triádicos, cujas falas seguem a sequências IR-E (pergunta - resposta - avaliação). Nas cadeias abertas, as sequências são compostas por enunciações coerentes com o padrão de dialogicidade, com perguntas e respostas qualitativamente mais coerentes com a comunicação em sala de aula. As relações de poder 
retratadas pelas relações interpessoais e influenciadas pelo conteúdo dos discursos docentes estão circunscritas a este eixo de análise.

O eixo padrões temáticos reúne elementos relacionados com o conteúdo cientifico e com a linguagem científica. No contexto da comunicação em sala de aula e da semântica da linguagem cientifica, podemos nos deparar como padrões temáticos em diferentes níveis de elaboração, os quais correspondem às escolhas docentes sobre o que ensinar e ao grau de apropriação do professor e dos estudantes sobre que está sendo ensinado. Ensinar a falar ciências e aprender a falar ciências são processos inter-relacionados aparentes no padrão temático da aula.

A configuração da mediação discursiva, mediante o conteúdo destes dois eixos, ancora a análise propriamente dita realizada com a intenção de conhecer a essência do trabalho docente realizado em sala de aula, a relação entre este e o desenvolvimento profissional do professor. Essa análise é mediada por conceitos, como motivo e objetivo, sentido e significação social e pela relação estabelecida entre a aprendizagem docente e o desenvolvimento profissional. $\mathrm{O}$ desenvolvimento profissional é visto a partir de indícios relativos a funções psíquicas em desenvolvimento ou ao processo de apropriação e domínio sobre modos de mediação. Eis esse movimento representado na figura seguinte:

\section{Figura 06 - Instrumento de análise}

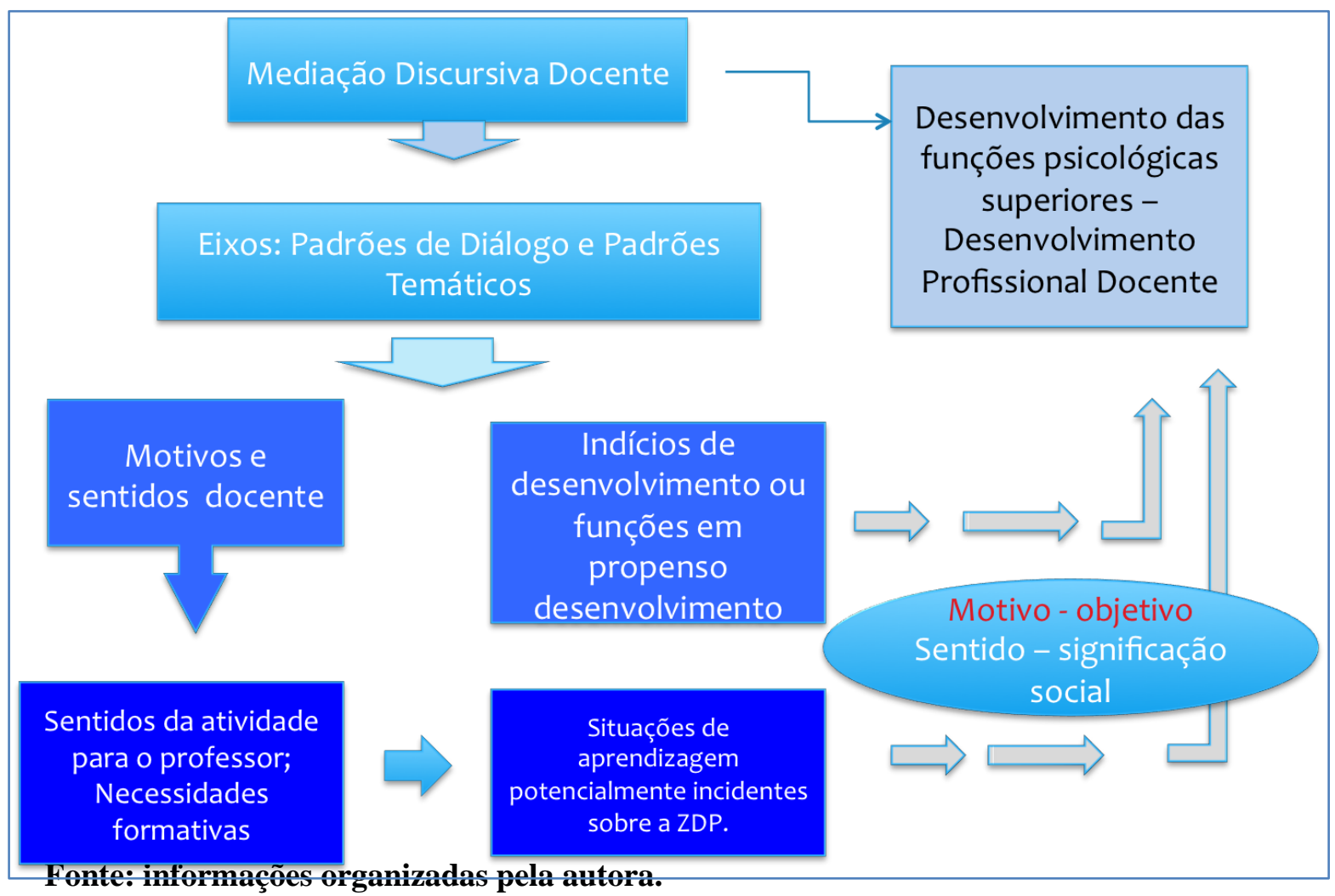




\subsection{Eixo e estrutura da análise}

O movimento dialógico discursivo inerente ao ensino e à aprendizagem em sala de aula perfaz o eixo central da análise. Esse movimento é analisado em episódios de ensino, oriundos de trechos recortados das aulas com conteúdo de interesse da pesquisa. Cada episódio é organizado em turnos de falas ou de enunciações, sendo esses turnos enumerados na ordem sequencial da conversação.

Assentado no sistema coletivo de atividade, o eixo que perfaz a análise é continuamente alimentado pela multivocalidade desse sistema, cujas vozes advêm das unidades vocais representativas dos contextos, dos quais a professora Verônica, sujeito escolhido para análise, participa ou tem acesso. Essas vozes contidas em sua memória podem influenciar o conteúdo de suas mediações discursivas.

Em outras palavras, o processo de análise dos episódios de ensino, recortados das aulas selecionadas, ancora-se sobre as vozes oriundas da vida profissional e formativa da professora Verônica, das conversações circunscritas às suas conversas com a coordenadora, às reuniões do grupo escola e dos fóruns formativos I e II, ocorridos na escola e na universidade, respectivamente. Outras vozes advêm da comunidade escolar constituídas nas reuniões de pais e em outros meios de comunicação estabelecidos com os familiares dos alunos; advém das orientações curriculares oficiais e do conteúdo das sequências didáticas elaboradas pelo LaPEF e das atividades produzidas pelo grupo de professoras. As vozes de apoio aparecem na análise nos seguintes formatos: episódios de formação, oriundos dos encontros formativos ocorridos nos fórum I e II, na escola e na universidade, respectivamente; episódios de entrevistas, estruturados a partir das entrevistas cedidas pela professora à pesquisadora; e citações com falas individualizadas dos sujeitos.

Os sujeitos são identificados da seguinte maneira: nos episódios de ensino, a professora é identificada como $\mathrm{P}$ e os alunos por falsos nomes; nos episódios de formação e nos episódios de entrevistas, professores recebem falsos nomes, formadoras no LaPEF são denominadas de Form. I e Form. II, coordenadora da escola, é identificada como Coord. e entrevistadora como Ent. Algumas vezes usamos a sigla EI e EII para abreviar e identificar as fontes de dados Entrevista I e Entrevista II, respectivamente.

O esquema desse processo de análise pode ser assim representado: 
Figura 07 - Representação do processo de análise

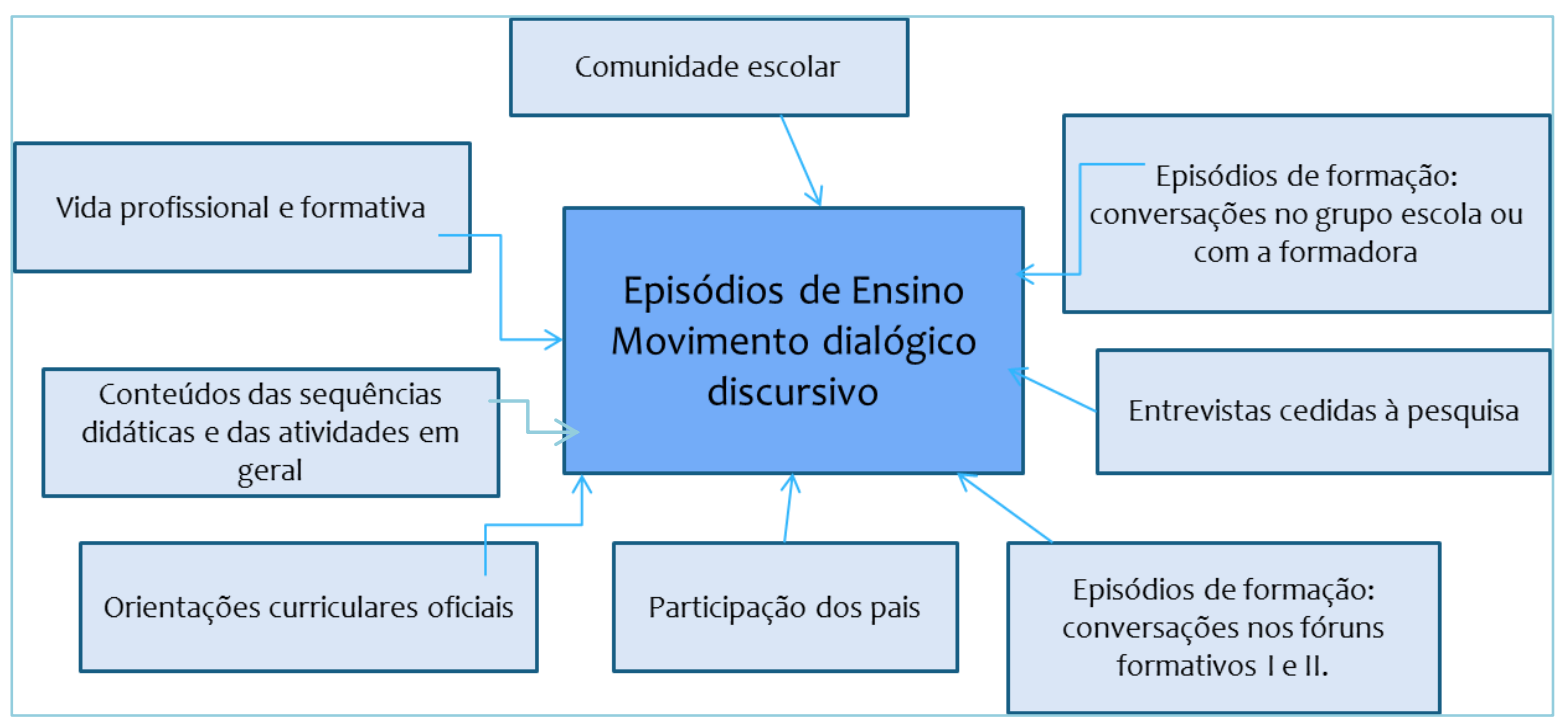

Fonte: informações organizadas pela autora

Como mostra o esquema, a análise, ainda que centralizada na sala de aula, é apoiada na ideia de que a atividade docente não se restringe a esse contexto, mas compreende os diferentes planos da docência realizados em situações coletivas e individuais, nas esferas dos planejamentos, desenvolvimentos e interpretações, portanto, influenciada por fatores multivariados.

No âmbito do sistema coletivo de atividade, essa perspectiva de análise poderia ser assim representada: 
Figura 08 - Representação do processo de análise no âmbito do sistema coletivo de atividade

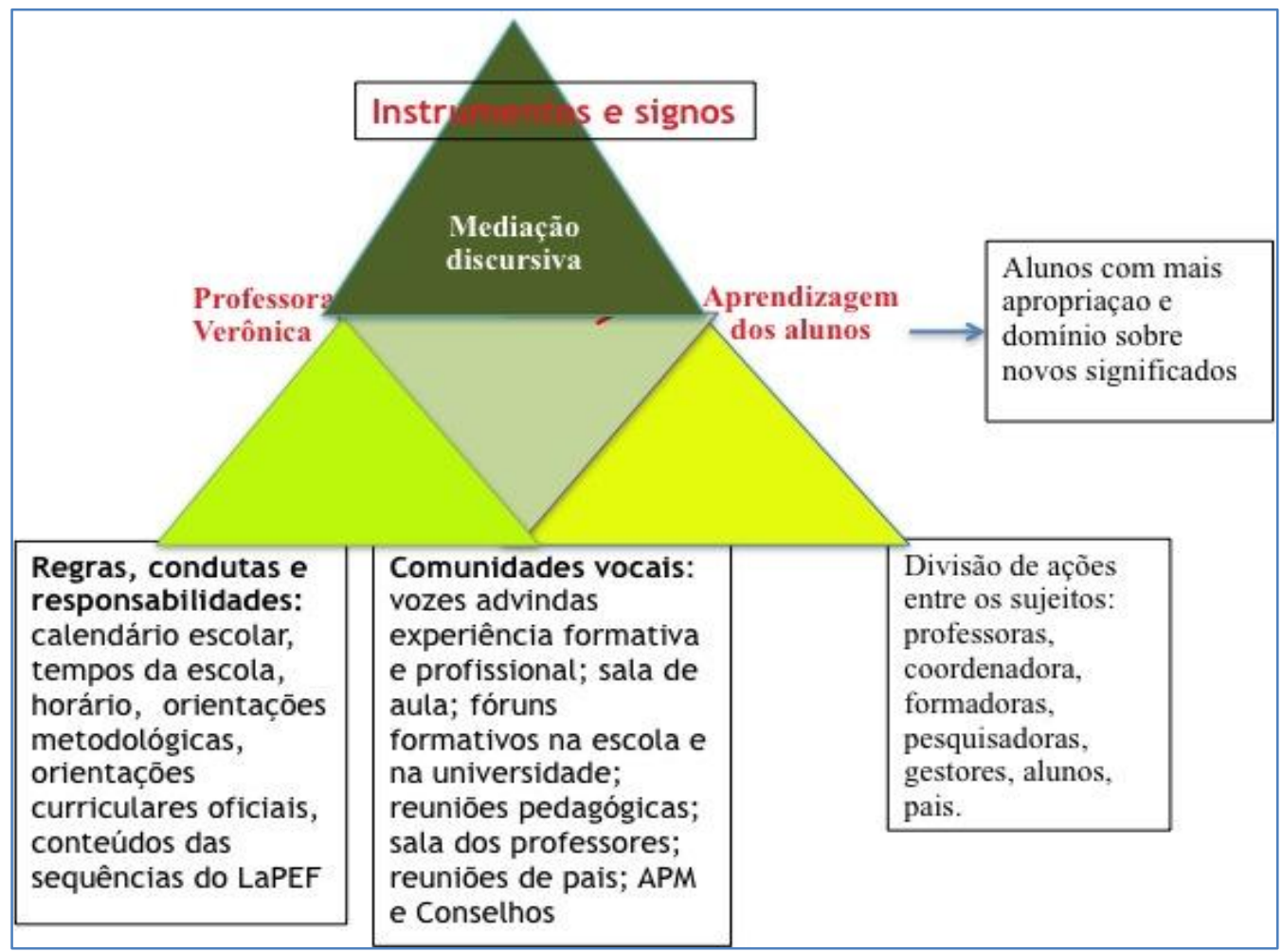

Fonte: informações organizadas pela autora

O trabalho docente em sala de aula está inter-relacionado com os demais vértices dos triângulos do sistema coletivo de atividade: instrumentos e signos são os modos de mediação docente, os quais integrados aos sujeitos determinam o fluxo do conjunto de ações eminentes ao ensino e aprendizagem; o modo geral de ação docente influencia e está sob influência direta das regras, condutas e responsabilidades inerentes ao movimento geral da escola, determinadas pelo calendário escolar oficial e por demais atividades que ocorrem paralelamente ao trabalho realizado em sala de aula; o processo de ensino de aprendizagem se constitui em ações divididas entre sujeitos, cada um com sua responsabilidade, sem esquecer do papel delegado aos alunos, como corresponsáveis pelo próprio processo de aprendizagem; não menos importante é o papel das comunidades vocais influenciando o conteúdo das mediações discursivas docente.

Em suma, a professora não entra sozinha em sua sala de aula: suas mediações, compostas por signos e instrumentos intermediadores das relações estabelecidas entre seus motivos/objetivos e a aprendizagem dos alunos, carregam não apenas elementos de sua trajetória formativa e profissional, mas de suas diferentes atuações e relações estabelecidas 
nos contextos intra e extraescolar. O objeto da pesquisa - a relação entre o trabalho em sala de aula e o desenvolvimento profissional da professora, se encerra na complexidade das interrelações intrínsecas ao movimento do sistema coletivo de atividade, representada na mediação discursiva, unidade que integra ação e linguagem docente.

Esclarecemos que a narrativa sobre a trajetória formativa e profissional da professora é apresentada textualmente no corpo da tese. Essa narrativa, reconstituída por meio de entrevistas, é valorizada por mostrar elementos importantes do ponto de vista processual e histórico, por conseguinte da gênese do processo de desenvolvimento profissional da professora. A consciência sobre o limite de se compor uma narrativa a partir da memória oral, sem apoio de outros vestígios documentais, nos faz guardar as devidas proporções sobre sua construção. Ao narrar as situações vividas no passado, a professora interpreta suas lembranças com seus olhos e vivências do presente, atribuindo-lhes sentidos coerentes com suas atuais percepções. Ainda assim, o conteúdo desses sentidos é valioso para esta investigação, exatamente, por nos falar dos motivos da professora e, por conseguinte, nos fornecer traços do seu quadro atual de possibilidades de desenvolvimento profissional em relação ao conteúdo do sentido atribuído coletivamente à profissão docente pela sociedade brasileira atualmente. Tal como afirma Duarte (2004) há um sentido coletivo produzido culturalmente pela sociedade, o qual pode ou não coincidir com o significado social. No caso da docência, como já mencionamos no primeiro capítulo deste trabalho, esse sentido cultural e social não coincide com o significado social dessa atividade.

Portanto, perguntamos: quais sentidos a professora Verônica atribui à sua atividade docente? Iniciaremos essa discussão escutando suas lembranças ou as vozes advindas de sua memória formativa e profissional.

\subsection{Eis a narrativa ${ }^{13}$ : história da vida profissional - Professora Verônica}

Verônica fez o curso de magistério e é graduada em Letras e Pedagogia. Atualmente leciona no Ensino Fundamental I, na rede Municipal de Ensino da cidade de São Paulo.

A sua trajetória profissional tem início em 1990, com 19 anos de idade, numa escola da rede Estadual de Ensino, situada em Francisco Morato - SP, onde trabalhava com uma classe de alfabetização de adultos.

\footnotetext{
13 As falas literais seguem o padrão geral adotado no corpo da tese, são apresentadas entre aspas e com identificação da autoria ao final.
} 
No início de sua trajetória profissional, suas aulas eram influenciadas pelas experiências de antigos professores e pelo que aprendeu no curso do magistério. Apoiava-se, sobretudo no método da cartilha para buscar alfabetizar seus alunos adultos. Com seis meses de experiência profissional, vivenciou junto aos seus alunos uma situação que a tocou profundamente:

Em sua aula, propunha a lição do periquito para ensiná-los a escrever palavras com 'que' e com 'qui'. Ao se aproximar de um dos alunos, viu que ele usava as letras 'ki' ao invés de 'qui'. Chamou a sua atenção com insistência para que ele fizesse o que ela havia lhe solicitado:

_ Olha eu já lhe falei o que é o 'q', o 'u', e o 'i',

$\mathrm{O}$ aluno, por sua vez, com muita humildade, disse:

_ “Ah, professora, é que eu pensei que pudesse ser o 'ki' do chokito!”

A professora, sem ainda compreender o que estava se passando, retrucou:

_ Mas o que é que tem a ver o 'ki' do chokito?

O aluno, timidamente, responde:

- O 'ki'.

A professora relata este episódio com muita emoção e diz que o último 'ki' dito pelo aluno lhe causou uma sensação muito estranha, se sentindo, por alguns instantes, paralisada diante do aluno, que a seu modo, com a sua experiência, lhe ensinava a ensinar, lhe alertava, provocando um "estalo" em seus pensamentos e reflexões.

Logo que possível, sob orientação de sua irmã, pedagoga e professora há mais tempo, procurou a equipe de formação da Delegacia Regional (DRE) de sua cidade com a intenção de fazer algum curso que viesse a contribuir com a melhoria da qualidade de suas aulas. A formadora da DRE, ao ouvir suas pretensões e o relato do ocorrido em sua aula, a incentiva a estudar mais sobre a alfabetização de adultos, a planejar suas aulas de modo que considerasse a experiência de vida de seus alunos, principalmente em relação às suas profissões, e a procurar estratégias de ensino mais adequadas ao trabalho com adultos. Tanto a situação vivida com o aluno, como a conversa com a sua formadora a fizeram questionar a sua atuação em sala de aula, especificamente, sobre a adoção da cartilha, passando a prestar atenção nos conhecimentos trazidos pelos alunos e em suas histórias de vida, o que a possibilitou saber que o aluno conhecia o 'ki' do chokito porque trabalhava como repositor de mercadorias em um supermercado. Dizia a professora: "Eram adultos, eram adultos! Analfabetos e eu dando cartilha! (...) Ba - be - bi - bo - bu, da - de - di - do - du. E eu achando que eles tinham que engolir tudo aquilo (...)". 
Em seguida, ingressou no grupo de estudos da DRE, no qual se estudava sobre a Psicogênese da Língua Escrita. No início ela ouvia muito, sem entender com profundidade a proposta pedagógica que fundamentava tais estudos. Havia leituras sobre a aprendizagem do aluno, sempre reiterando a ideia de que os alunos não são uma tábula rasa, que eles quando vão para escola, já têm conhecimentos. Na verdade, de tudo que ela ouvia, o que mais a tocava era que se tinha uma nova maneira de alfabetizar, de aprender e de ensinar. Com o avanço dos estudos, as leituras e discussões ganhavam cada vez mais sentido, principalmente, pelas relações que ela já conseguia estabelecer com sua prática de sala de aula.

No mesmo ano, ainda com pouca experiência profissional, foi convidada a participar de outro curso organizado com uma dinâmica diferenciada, em que os professores participantes eram responsáveis pelo repasse do conteúdo aprendido para outros professores de suas respectivas Delegacias de Ensino. Em decorrência do seu bom desenvolvimento neste novo desafio, em um pequeno espaço de tempo, a professora Verônica se tornou formadora de professores pela DRE de sua região.

Outro marco importante em seu processo formativo foi o seu ingresso, logo depois, em um curso de 04 anos pela Fundação para o desenvolvimento da Educação (FDE) na área de educação de adultos, estruturado sob a mesma dinâmica do anterior, o qual lhe delegou o papel de "professora capacitadora". Para a professora, o que mais a fez aprender neste curso foi a própria dinâmica, em "que tudo que se aprendia na teoria, a gente tinha que aplicar na prática, voltar para a FDE, expor sua prática". Esse processo formativo envolvia diferentes áreas, como história, geografia, matemática e português, ficando de fora a área de Ciências Naturais.

Seus estudos eram mais direcionados para a área de alfabetização na língua materna, o que a levou a se graduar em Letras em 2001, com algumas experiências na função de professora de Português no Ensino Fundamental II e Médio. Até então, a sua experiência profissional era com alfabetização de adultos e com o Ensino Fundamental I em escolas da rede Estadual e da rede privada.

Seu primeiro contato com a área de Ciências Naturais se deu com o seu ingresso na EMEF Candido Portinari em 2007, se envolvendo, logo ao chegar, com os projetos em desenvolvimento na Unidade Escolar, sobretudo com a proposta metodológica para o ensino de ciências em construção junto ao Laboratório de Ciências.

Com o estabelecimento da parceria entre a escola e o LaPEF em 2008, ela se destacou como uma das professoras mais envolvidas, permitindo que suas aulas de ciências fossem videogravadas por pesquisadores da universidade. Embora se declarasse insegura em 
relação aos conhecimentos científicos, predispunha-se a planejar, a pesquisar e a tirar dúvidas com as coordenadoras, formadoras da universidade e colegas de trabalho, tanto nos encontros formativos, como no dia-a-dia na escola.

Para a professora, o trabalho coletivo realizado na escola junto às suas parceiras de trabalho tinha grande importância em sua aprendizagem como professora e considerável influência em seu trabalho de sala de aula. Ela se refere tanto ao coletivo docente, como à sua convivência com as professoras que ensinavam no mesmo ano do Ciclo e com a coordenadora dos projetos do Laboratório de Ciências, com quem se comunicava com frequência por via presencial e via correio eletrônico.

Depois de três anos nesse movimento, ela se diz mais corajosa para ir além do livro didático de ciências, para planejar atividades, formular problemas de aprendizagem, organizar e realizar as experimentações e para selecionar e até produzir textos para os alunos. Os conhecimentos científicos parecem não lhe assustar tanto quanto antes.

É possível notar marcos importantes de aprendizagem na trajetória profissional da professora, seja em sua relação com parceiras mais experientes, seja em situações vivenciadas em sala de aula. Como foi possível verificar em seu relato, os processos formativos vivenciados, a sua atuação em sala de aula, bem como as diferentes intervenções dos alunos, se configuram como motivos que lhe impele ao estudo e como possibilidades de reflexões sobre sua prática docente.

Em relação à sua atuação em sala de aula, destaca outro momento junto com crianças de $2^{\circ}$ ano, durante o desenvolvimento da Atividade Investigativa de Aprendizagem "Dinossauros e a pré-história humana", em que ela perguntou aos alunos se na época dos dinossauros existiam seres humanos. Os alunos levaram este questionamento para discutir com seus pais e trazer os resultados no dia seguinte. Para surpresa da professora, um dos alunos trouxe um livro religioso, no qual a autora afirmava que os dinossauros também entraram na arca de Noé. A mãe foi até a porta da sala de aula para entregar o livro e solicitar que fosse lido para toda a classe. Estrategicamente, a professora adiou a discussão para o dia seguinte para que tivesse tempo de pensar e planejar como resolveria tal situação. Como de costume, conversou com seus pares, entrou em contato com a coordenadora do Laboratório de Ciências por telefone e, então, decidiram que o livro seria lido em partes, e que se esclareceria aos alunos que a visão apresentada era de uma determinada religião, e que, concomitantemente, se iria estudar a visão científica a respeito. Desse modo, as duas linguagens foram respeitadas e todos ficaram satisfeitos. Na roda de conversa realizada ao final das atividades, os alunos mostraram muitos conhecimentos a respeito do assunto e não 
se referiram a nenhum dinossauro entrando na arca de Noé. Esse foi mais um episódio que mostrou à professora a amplitude de sua profissão e a sua importância como profissional na formação cultural das crianças.

Encontramos também em seus relatos sobre sua história de vida, marcos importantes associados à construção de sentidos e significados relacionados à sua profissão. Verificamos que essa construção se iniciou muito antes de sua trajetória profissional, ainda menina, aluna de Dona Arlete, professora que muito lhe ensinou na $3^{\mathrm{a}}$ e $4^{\mathrm{a}}$ série primária, quando ainda morava em Novo Horizonte, cidade do interior de São Paulo, onde nasceu e estudou até se formar no curso de magistério. A professora Arlete a marcou pelo seu método de ensino, uma mescla de braveza com atividades agradáveis, como jogos e brincadeiras. Outros aspectos faziam de Dona Arlete uma professora diferente aos seus olhos:

Eu acho que ela era diferente. Eu estudei na época do militarismo, no interior, uma cidade
pequena, e eu me lembro de que ela fazia umas atividades muito diferentes com a gente.
Começava assim, sentava menino e menina, que ela falava que homem tinha respeitar
mulher e vice versa. (...) e eu me lembro de que ela falava assim 'se o Sr. Joao chegar na
porta, todo mundo vai guardar essa folha e nós vamos pegar o livro tal'. Olhe que
interessante! E a gente pegava aquele livro. Era o diretor. E de vez em quando ele
aparecia mesmo, tinha uma janelinha na porta da sala.

Em sua meninice, Verônica não compreendia por que a professora Arlete propunha atividades às escondidas do diretor, mas sob o seu olhar de hoje compreende e admira a atitude de subversão e de até correr riscos para garantir um ensino melhor para seus alunos. "Eu acho, assim, que ela ia pra dar aula mesmo pra gente (...), eu acho que isso eu tenho de Dona Arlete".

Ensinar de modo a ajudar seus alunos a pensar sobre as coisas, a estabelecer relações é o sentido que a atividade pedagógica tem para Verônica, correspondente com a significação social de sua docência - “(...) Tornar o aluno uma pessoa questionadora, que tenha opinião”, coerente com o que ela pensa sobre o papel da educação, o "de formar mesmo as pessoas para serem seres políticos".

Mais dois aspectos falam do sentido que ela atribui à educação: um é a sua vontade de voltar a trabalhar com formação de professores, sobretudo pelo seu propósito de propor discussões mais profundas, relacionadas à função social da educação, pois, a seu ver, os professores precisam acreditar mais em seus alunos como sujeitos que são capazes de 
aprender, sejam eles crianças ou adultos, e ter clareza sobre sua função na sala de aula, de como agir para que seus objetivos sejam alcançados. O outro é a sua identificação com adultos analfabetos, com os quais prefere trabalhar, embora goste muito de ensinar para crianças. O seu papel junto às crianças é encaminha-las para as descobertas próprias da idade, enquanto que com os adultos "atropelados pela vida", sua responsabilidade é ajudá-los a recuperar a fase perdida por diversos motivos alheios à sua vontade. Para ela, essa responsabilidade, maior do que a de educar crianças, engrandece a sua docência e a torna uma pessoa melhor.

Ainda que reconheça criticamente a situação de desprestígio pela qual atravessa a educação pública no Brasil, bem como a profissão docente, a professora assume o seu compromisso ideológico com a continuidade de construção de novos sentidos para a sua atuação, seja em convívio com seus alunos, seja com seus pares.

Em suma, os depoimentos que embasam esta narrativa contribuem para a construção do modo geral de ação da professora Verônica, relacionado ao seu processo de desenvolvimento profissional, aqui abordado de modo retrospectivo e prospectivo, portanto mutável e fluído, tal qual deve ser a sua Zona de Desenvolvimento Proximal. Esse modo geral de ação será complementado com as análises de episódios recortados de suas aulas, discutidos no próximo capítulo.

Para efeito de atualização, informamos que, atualmente, a professora, embora trabalhe em outra unidade escolar, participa e colabora com projetos em andamento na EMEF Candido Portinari, desenvolvidos a partir do laboratório de ciências, como por exemplo, o Observatório da Educação: "Educação Matemática nos anos iniciais do Ensino Fundamental: princípios e práticas de organização do ensino", realizado em parceria com pesquisadores do Laboratório de Matemática da FEUSP. No âmbito desse projeto, sua atuação abrange a participação em reuniões ocorridas na universidade, o desenvolvimento de atividades em sua sala de aula e orientações formativas a suas colegas de trabalho em encontros quinzenais organizados por ela para esse fim.

Esta informação reforça o que dissemos sobre o caráter prospectivo do desenvolvimento profissional da professora, além de mostrar a sua permanente busca por processos formativos que contribuam com sua aprendizagem como docente. 


\section{Capítulo V - A análise}

"E aí nós vamos buscar respostas para essas dúvidas, o que vocês acham? Tudo bem? Então o nosso compromisso para a próxima aula é buscar respostas para essas dúvidas que ficaram" Profa. Verônica

Iniciamos este capítulo com a apresentação dos dados organizados para análise, sintetizados no quadro seguinte. É possível visualizar as aulas escolhidas, correspondentes episódios de ensino e episódios de formação, nos quais se encontram vozes de apoio à professora em sua classe. Outras comunidades vocais são identificadas na última coluna à direita.

\subsection{Os dados analisados}

\section{Quadro II - Síntese com dados analisados}

\begin{tabular}{|c|c|c|c|c|c|}
\hline Aulas & Episódios de ensino & $\begin{array}{c}\text { Tempo em } \\
\text { minutos }\end{array}$ & $\begin{array}{l}\text { Episódios de } \\
\text { formação }\end{array}$ & $\begin{array}{l}\text { Fontes do } \\
\text { episódio } \\
\text { de } \\
\text { formação }\end{array}$ & $\begin{array}{c}\text { Outras } \\
\text { comunidades } \\
\text { vocais } \\
\text { explícitas na } \\
\text { aula }\end{array}$ \\
\hline \multirow{8}{*}{$\begin{array}{c}\text { Para cima e } \\
\text { para baixo } \\
\text { com o } \\
\text { submarino } \\
(08 / 04 / 2008)\end{array}$} & I - Como ler o texto & $\begin{array}{l}01: 20 \mathrm{a} \\
02: 45\end{array}$ & & & $\begin{array}{l}\text { Sequência } \\
\text { didática "O } \\
\text { submarino" }\end{array}$ \\
\hline & $\begin{array}{l}\text { II - Cilindros e válvulas } \\
\text { do submarino }\end{array}$ & $\begin{array}{l}04: 30 \mathrm{a} \\
05: 18\end{array}$ & & & idem \\
\hline & $\begin{array}{l}\text { III - Compreensão do } \\
\text { conteúdo do texto }\end{array}$ & $\begin{array}{l}07: 49 \text { a } \\
09: 24\end{array}$ & $\begin{array}{l}\text { Professora } \\
\text { Verônica em } \\
\text { situação de } \\
\text { aprendizagem }\end{array}$ & $\begin{array}{l}\text { Fórum II - } \\
27 / 08 / 2008\end{array}$ & idem \\
\hline & $\begin{array}{l}\text { IV - Qual o foco de } \\
\text { atenção dos alunos na } \\
\text { aula }\end{array}$ & $\begin{array}{l}09: 27 \text { a } \\
10: 24\end{array}$ & & & idem \\
\hline & $\begin{array}{l}\text { V - Pergunta autêntica } \\
\text { como ponto de inflexão } \\
\text { na conversação }\end{array}$ & $\begin{array}{l}10: 26 \mathrm{a} \\
11: 26\end{array}$ & & & idem \\
\hline & $\begin{array}{l}\text { VI - Uma } \\
\text { descontinuidade na } \\
\text { conversação: para que } \\
\text { serve as válvulas do } \\
\text { submarino? }\end{array}$ & $\begin{array}{l}11: 27 \mathrm{a} \\
12: 44\end{array}$ & & & idem \\
\hline & \multirow{2}{*}{$\begin{array}{l}\text { VII - Pergunta } \\
\text { autêntica gera } \\
\text { compartilhamento de } \\
\text { informações }\end{array}$} & \multirow[t]{2}{*}{$\begin{array}{l}16 ; 16 \text { a } \\
17: 39\end{array}$} & & & idem \\
\hline & & & & & Continua \\
\hline
\end{tabular}




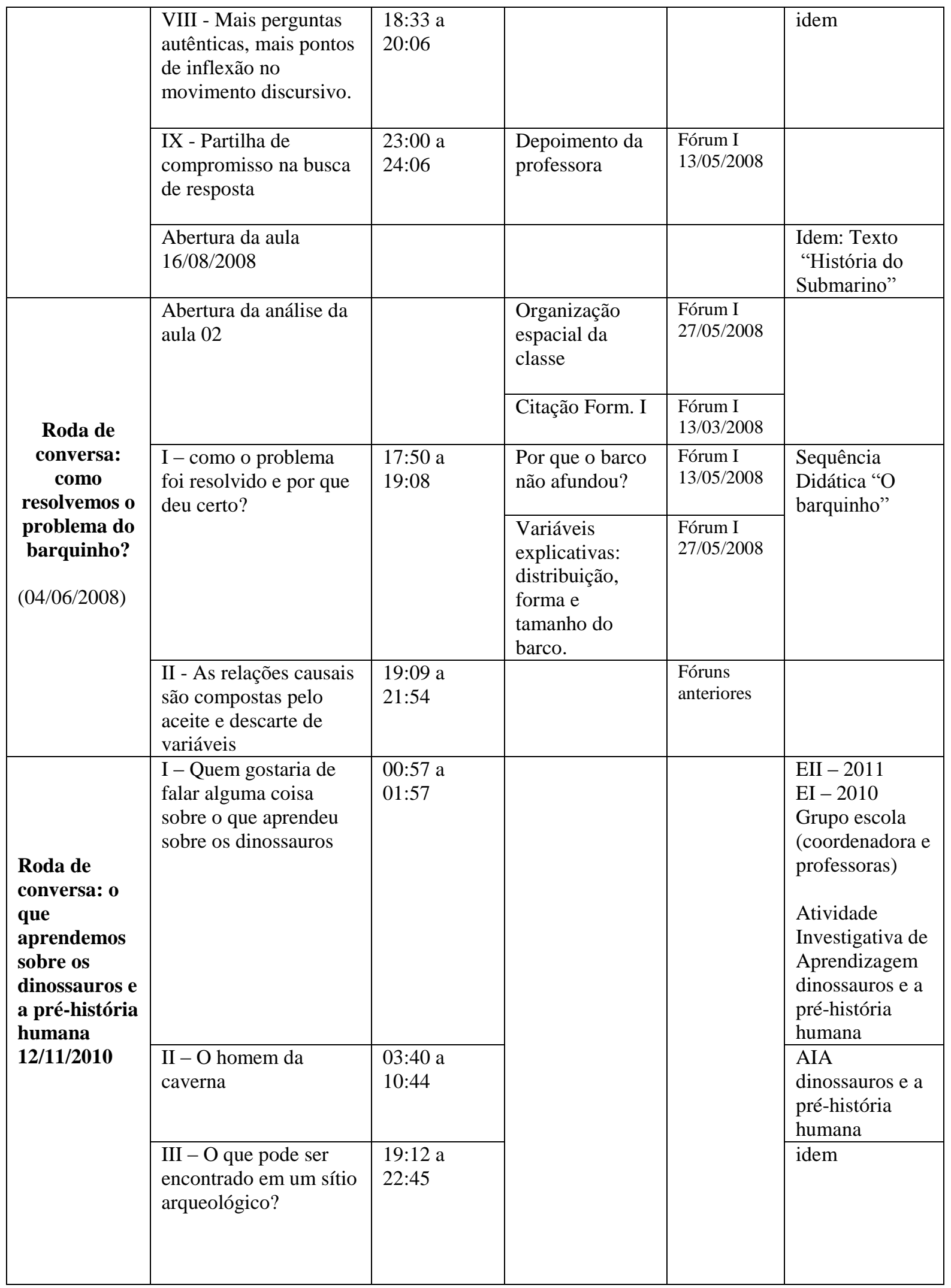

Fonte: informações organizadas pela autora 


\subsection{Aula 01 - "Para cima e para o fundo com o submarino".}

A aula "para cima e para o fundo com o submarino" é uma das ações da sequência didática "o submarino"14, que compõe o módulo de ensino intitulado "Debaixo d'água", incluso em uma das sequências didáticas elaboradas pela equipe de pesquisadores do LaPEF. Esse módulo de ensino foi desenvolvido em classes de $4^{\circ}$ ano do ensino fundamental I ou $4^{\mathrm{a}}$ série, com alunos na faixa etária de 09 a 10 anos.

Na primeira aula, após uma discussão sobre os conhecimentos prévios da classe acerca do que é um submarino, os alunos foram desafiados a fazer com que um submarino, feito de garrafa plástica, emergisse e submergisse dentro de um balde cheio de água. Após manusear experimentalmente e resolver o problema, os alunos conversaram sobre as ações realizadas no processo de resolução e por que o submarino afundou e flutuou. As ações consistiram em sugar um canudo acoplado à boca da garrafa, fazendo o submarino se encher de água e afundar; e em assoprar esse canudo para expulsar a água do submarino, enchendo-o de ar, levando-o a subir para a superfície do balde. A roda de conversa é finalizada com a conclusão de que o submarino afunda quando está cheio de água, e flutua quando tem apenas ar, porque a água é pesada e o ar é leve. Ainda nesta aula, os alunos se detiveram à produção de um relatório - escrita espontânea de um texto ilustrado sobre o processo de resolução do problema.

$\mathrm{Na}$ aula seguinte, datada de 08 de abril de 2008, a professora propôs a leitura do texto constituinte da sequência didática, intitulado "entendendo o problema: para cima e para baixo com o submarino": professora Verônica, posicionada à frente da classe, se dirige a seus alunos, sentados individualmente, cada qual com o texto em cima da carteira. Todos em silêncio, olhando para a lousa, onde Yuri, a pedido da professora, desenha um submarino. Yuri se esqueceu de desenhar a hélice, ausência notada pela professora e repassada à classe na forma de uma pergunta - "falta alguma coisa?". A classe responde em coro que falta o "ventilador", outros falam "hélice", o que faz o aluno desenhista voltar à lousa e completar o seu desenho. Não sabemos ao certo de onde decorreu o conhecimento da classe sobre a hélice, como parte do submarino. Talvez tenha sido compartilhado na discussão geral sobre a

\footnotetext{
14 A Sequência Didática "Submarino" foi publicada no livro didático: Coleção Investigar e aprender ciências $4^{\circ}$ ano, São Paulo, Editora Sarandi, 2011. Autores: Carvalho, A. M. P.; Oliveira, C.; Sasseron, L. H.; Sedano, L.; Batistoni, M.
} 
temática a ser estudada realizada na abertura da primeira aula ou advindo de alguma pesquisa orientada pela professora do Laboratório de Informática.

A professora fica satisfeita com o desenho, ainda que a hélice tenha ficado proporcionalmente pequena para o tamanho do submarino desenhado, motivo de risos de muitos dos envolvidos. A imagem representada na lousa já se constitui como um signo mediador interposto entre a intenção de ensinar de modo que os alunos aprendam e a própria aprendizagem dos alunos. Essa imagem não é senão um símbolo representativo da temática em estudo.

Os alunos continuam atentos às enunciações da professora, as quais, associadas à ação do aluno Yuri em desenhar o submarino na lousa e à imagem produzida, cumpriram o objetivo de dirigir a atenção dos alunos para o motivo orientador da atividade - aprender porque os corpos afundam e flutuam na água. Em tal cenário, professora à frente da classe e alunos com o texto sobre suas carteiras e prontos para ouvir as próximas orientações docentes, dá-se início à atividade de leitura prevista. Este é o contexto, no qual ocorre o episódio I.

\section{Episódio de ensino I - Como ler o texto}

(1:20) 13. P - Então, olhem só! Vamos só retomar um pouquinho: nós fomos até o laboratório, fizemos uma experiência em grupo, voltamos pra sala de aula, cada um registrou, foi escrito o como foi a experiência e o que aprendeu lá, não foi isso? (...) Depois nós fizemos um relatório coletivo, estão lembrados? Escrevemos um texto sobre o que fizemos e aprendemos, não foi isso? Agora hoje eu trouxe um texto pra vocês, retomando tudo isso. Vamos ler o texto? Então vai ser assim: essa leitura hoje vai ser um pouquinho diferente, eu não vou ler em voz alta, tá? Eu vou dar um tempo pra que vocês leiam, e vai ser individual, não vai ser em dupla também. Vocês vão pegar o lápis de cor amarelo, todo mundo tem. Pode ser claro, escuro, mas de cor amarelo. E aí nós vamos usar o lápis de cor amarelo como um marca-texto. Vocês já ouviram falar em marcatexto, não é? Então, vocês vão grifando o que vocês acharem mais importante nesse texto. Leiam sozinhos e o que vocês acharem interessante vocês grifam com o lápis amarelo e depois nós vamos discutir juntos. Entenderam? (02:45)

No turno 13, a mediação discursiva docente consiste em uma síntese das ações já realizadas em aulas anteriores. O objetivo imediato da síntese realizada pela professora não é senão organizar o processo de aprendizagem, mediante a ativação da memória dos alunos em prol da organização dos pensamentos deles. Esse movimento é possível a partir de signos, organizados em sua mente, mediadores de suas ações e de sua comunicação com os alunos. A 
síntese reflete o seu domínio sobre a totalidade do processo, cujos elementos estão pontuados, um a um, cronologicamente.

Para Edwards e Mercer (1988, p. 101), essa síntese de ações consiste em uma recapitulação, a qual explicita uma "continuidade de experiência contextual compartilhada", isto é, a compreensão alcançada conjuntamente em contextos anteriores, seus aspectos mais significativos, servem agora como ponto de partida e de continuidade na presente aula. Em outras palavras, essa síntese ou recapitulação é o posicionamento do assunto a ser tratado na aula atual em continuidade às ações realizadas anteriormente, de modo a construir um contexto mental, ou seja, uma compreensão compartilhada do que se havia feito e dito, e de como essa compreensão poderia ser convertida em um contexto mental que assegurasse um novo modo de ação ou de compartilhamentos de novas compreensões.

É exatamente isso que ocorre na sexta linha do turno 13, com a finalização da recapitulação e apresentação da nova proposta: a professora convida a classe para a leitura de um texto, sugerindo a sequência de ações por meio da qual ela deseja que a leitura seja feita. O texto físico e o marca texto tomam a forma de instrumentos intermediadores; nesse raciocínio, o conteúdo do texto e o grifo são considerados signos ou instrumentos psicológicos. Instrumentos e signos se combinam para mediar o processo de ensinar da professora e de aprender das crianças.

Esses signos e instrumentos conformam um conjunto de ações e/ou operações por meio das quais os alunos devem realizar a ação de leitura, as quais vão sendo pontuadas em contraponto com o que não deve ser feito: a professora não lerá em voz alta e dará um tempo para que cada um leia sozinho; a leitura deve ser realizada individualmente e não em duplas; o texto será marcado com um lápis amarelo. O conteúdo da mediação guarda a intenção de orientar a atenção conjunta do grupo classe para aspectos concretos da atividade de leitura, ou seja, direcionar o motivo dos alunos para a interpretação e entendimento do conteúdo do texto.

A aula, a princípio, uma ação inserida no corpo da atividade de ensino da professora, tem o seu motivo/objetivo relacionado ao objetivo de criar oportunidades de aprendizagem referentes ao aprender a ler e à construção de significados; e da atividade de estudo dos alunos, cujo motivo deve coincidir como o objetivo de realizar as ações de leitura para a apropriação de significados referentes à base conceitual em questão. Nos detalhes da orientação docente, até a cor do grifo foi delimitada. Ler em dupla, com o acompanhamento 
da leitura em voz alta pela professora, parece ser o modo frequente de se realizar essa ação, alterado na presente aula. Informamos a tempo que as formadoras do LaPEF não delimitam uma dinâmica de leitura e nem mesmo modelos de ações para cada aula a serem seguidos pelas professoras, o que preserva as suas iniciativas e modos próprios de exercício de seu trabalho.

É possível notar essa ressalva na ação propositiva da professora. Ainda que esteja realizando uma sequência de ações propostas pelos pesquisadores do LaPEF, atividade que poderia ser qualificada como de reprodução, ela a faz privilegiando o seu estilo de trabalho. $\mathrm{O}$ modo de leitura proposto insere-se em seu processo de criação, como uma ação de reprodução associada a uma ação de combinação (Vigostki, 2009a).

Para Vigotski, no âmbito do comportamento humano e da atividade especificamente humana, é possível distinguir, de modo geral, dois tipos principais de processos criativos:

Um tipo de atividade pode ser chamada de reconstituidor ou reprodutivo. Está ligado de modo íntimo à memória; sua essência consiste em reproduzir ou repetir meios de conduta anteriormente criados e elaborados ou ressuscitar marcas de impressões precedentes. (2009 a, p. 11). (...) A base orgânica dessa atividade reprodutiva ou da memória é a plasticidade da nossa substância nervosa (idem, p. 12).

Dessa forma, nosso cérebro mostra-se um órgão que conserva nossa experiência anterior e facilita a sua reprodução (ibidem, p. 13).

Além da atividade reprodutiva, é fácil notar no comportamento humano outro gênero de atividade, mais precisamente a combinatória ou criadora. (...) O cérebro não é apenas um órgão que conserva e reproduz nossa experiência anterior, mas também o que combina e reelabora, de forma criadora, elementos da experiência anterior, erigindo novas situações e novo comportamento (idem ibidem p. 14).

Por suposto, ao planejar e decidir sobre o modo como mediará a leitura de seus alunos, a professora trouxe à sua memória sua experiência como docente, lembrou-se de ações bem sucedidas, as combinou com outras criadas naquele instante, foi introduzindo instrumentos e signos, a seu ver, importantes e facilitadores do processo de decodificação, interpretação e síntese. Com base no pensamento vigotskiano citado acima, afirmamos que as ações de planejamento da presente aula perfazem um ato criativo, ainda que simples diante da complexidade do ato de ensinar ciências para crianças, combinado ao ato de ensinar a ler.

A despeito de tal complexidade, transparece nas ações da professora, pelo menos no corpo deste episódio, a fluidez e a segurança em seus atos de ensinar, traduzidas, nesse instante, em seu caminhar entre as carteiras, acompanhando e colaborando com as crianças 
que apresentam mais dificuldades, ou seja, com aquelas que ainda não dominam as operações necessárias à leitura. Para Wertsch (1999) a leitura envolve engajamento ativo e dialógico, daí presumirmos que o ato de ensinar a ler também requer que o professor esteja ativo e engajado dialogicamente, do contrário seria, se não impossível, muito difícil envolver os alunos em tal dimensão.

Colocar os alunos em atividade e garantir o seu engajamento dialógico com o texto em leitura parece ser o motivo/objetivo da professora, consubstanciado e enunciado em sua mediação discursiva docente - criar uma oportunidade de aprendizagem mediante um modo sistematizado de se ler um texto, está implícito às ações de planejamento, materializado em suas enunciações propositivas. A sua atenção se volta para realizar esse motivo, torná-lo coerente com seu objetivo de realização da aprendizagem dos alunos, seja por meio do domínio da ação de leitura, seja pela apropriação do conteúdo cientifico. A realização desse motivo condiz com o seu processo de aprendizagem como docente, com o acréscimo de elementos ao seu processo de desenvolvimento profissional, não apenas por realizar o seu processo de criação junto aos seus alunos, mas pelos efeitos de suas mediações sobre a plasticidade de seu cérebro, propriedade que permite a esse órgão ser alterado com conservação dessas alterações. Segundo Vigotski (2009a), esse é o modo pelo qual o cérebro humano se forma e se reforma a cada vivência de experiências que tenham significados e que façam sentido diante dos propósitos pessoais e da função social da atividade, na qual se esteja inserido.

A aula continua, e há uma criança com o braço levantado. Seguimos, então para o próximo episódio.

\section{Episódio de ensino II - Cilindros e válvulas no submarino}

(04min: 30seg) 21. Felipe - O que é cilindro?

22. P - Vou explicar um pouquinho. Vamos imaginar que esse submarino foi cortado aqui (faz risco no meio do submarino de cima a baixo), tá? Como que eu vou explicar? Vocês já viram aquele tubo de oxigênio que vocês falaram ontem, usado pelos mergulhadores, já viram os extintores de incêndio que a gente tem, aquele tubo vermelho? Aquilo é um cilindro. Entenderam?

23. Gisele - Para que servem as válvulas?

24. P - Vamos terminar de ler o texto e nós vamos discutir isso juntos, mas grife aí como uma dúvida sua. O texto não respondeu essa pergunta sua Gisele? O texto não respondeu isso? Já leram? (05min: 18seg) 
Duas perguntas autênticas enunciadas por alunos marcam e desencadeiam o padrão temático do episódio. Perguntas autênticas nos fazem lembrar de que a aula em análise é composta por uma sequência de enunciações coerente com uma cadeia aberta, cujo padrão não segue rigidamente o modelo triádrico (I-R-E), aquele em que a pergunta enunciada pela professora gera uma resposta de instrução, como tal, prevista por ela, proferida para fins avaliativos. Recordamos também que a autenticidade da pergunta é explicada pelo fato de que o seu enunciador a profere porque deseja saber o que ainda, de fato, não sabe. Ou seja, a pergunta autêntica difere substancialmente da pergunta de instrução, sobretudo na necessidade e objetivo do enunciador, a de satisfazer uma necessidade cognitiva ou obter uma informação e a de verificar a aprendizagem, respectivamente.

A pergunta do Felipe no primeiro turno, contextualizada no conteúdo do texto em leitura, corresponde à forma do submarino, respondida pela professora por meio de uma analogia. Vale destacar que a professora, antes de iniciar o seu pensamento analógico, faz uma pausa, talvez para pensar ou, quem sabe, para se lembrar de alguma(s) voz(es) interior(es) e decidir sobre o conteúdo de sua próxima mediação. Essa pausa e possível processo de pensamento foram verbalizados por meio de uma auto pergunta: "como vou explicar?".

Segundo Santos, Terán \& Silva-Forsber (2011), a analogia é reconhecida na literatura sobre ensino de ciências como um recurso de comunicação, adotado em auxílio à linguagem ordinária quando esta não se fizer suficiente na construção de determinada ideia. Trata-se de comparações explícitas estabelecidas "entre um conceito alvo e uma imagem ou objeto que o represente" (idem, p. 593). Segundo os autores supracitados, essas comparações são explicitadas por um pensamento analógico, como tal não estabelecido por uma relação de semelhança entre objetos diferentes, mas por meio de pensamentos que buscam correspondência de semelhanças entre campos distintos.

No caso de nossa professora, a sua mediação discursiva contempla a analogia do tipo estrutural, estabelecida entre o signo-imagem (forma cilíndrica do submarino) com mais dois campos distintos, porém semelhantes em relação à forma física. Para fazer com que seus alunos se apropriassem do signo cilindro, desconhecido por eles, ela explicita o seu pensamento analógico e os conduz a pensar também por meio desse recurso, a comparar esse signo com mais dois outros conhecidos por eles e presentes em seu contexto social e cultural. 
Um deles, a forma cilíndrica do extintor de incêndio, lhes é familiar por existir em locais estratégicos da escola; o outro, a estrutura e forma cilíndrica do balão de oxigênio do mergulhador, pertence ao padrão temático de aulas anteriores, tal qual lembra a professora.

Na verdade, o que estamos caracterizando como pensamento analógico não é senão a interposição de signos já conhecidos pelos alunos a fim de leva-los a apropriação de determinado signo até então desconhecido. A analogia é posta em prática como um recurso de comparação ou de estabelecimento de relações entre contextos diferentes. Aliás, o estabelecimento de relações é um modo de mediação bastante valorizado pela professora, referendado por ela própria em depoimentos enunciados na composição da narrativa sobre sua história de vida formativa e profissional. Esse modo de mediação comparece em outras mediações discursivas, portanto será retomado no decorrer da análise.

Ao redirecionarmos nossa atenção para a continuidade da aula, notamos que o compartilhamento de informações em realização pela professora foi interrompido por mais uma pergunta autêntica. A aluna Gisele quer saber sobre o funcionamento das válvulas do submarino, dúvida não resolvida imediatamente pela professora, a qual opta por orientar a busca de resposta na leitura do texto. Por ora, interpretamos essa mediação docente como uma forma de incentivo à continuidade da leitura, e não como a expressão de um ato de ignorar a pergunta da criança.

Durante alguns minutos a professora passa entre as carteiras, conversando com as crianças sobre métodos diferentes de se grifar um texto. Ela nota que Mateus e outros alunos leram e grifaram simultaneamente, enquanto que outras crianças leram todo o texto e depois grifaram, certamente numa releitura. Ao final do seu percurso pela sala, retorna à frente da classe, elogia os métodos usados para ler e grifar o texto e solicita atenção para o início da discussão a respeito do que foi lido - conteúdo do próximo episódio. Os alunos abandonam seu lápis/marca-texto e voltam a sua atenção para a professora.

\section{Episódio de ensino III - Compreensão do conteúdo do texto}

(07min: 49seg) 29. P - Tá bom. Então, podemos? Primeiro, vamos lá. Qual é o assunto deste texto? Nós vamos combinar assim, ergue o braço para responder. Fala Felipe, qual é o assunto do texto? 
(Antes mesmo de a professora concluir sua enunciação, várias crianças já estão de braços erguidos, e permanecem erguidos até obter espaço na conversação. A professora vai apontando para quem vai falar)

30. Felipe - Submarino.

31. P - Fala o quê sobre o submarino? Fala Vítor.

32. Vítor - Como ele sobe, como ele desce, como ele fica debaixo d'água.

33. P - Tinha alguma novidade para vocês? O que tinha de novidade para vocês? O que que tinha, Everson?

34. Everson - Que ele descia.

35. $\mathbf{P}$ - Ele quem?

36. Everson - O Nautillus

37. $\mathbf{P}$ - Nautillus. Fala Wallace.

38. Wallace - que ele parecia um cilindro nas extremidades

39. $\mathbf{P}$ - Ele quem?

40. Wallace - O Nautillus

41. P - Nautillus. Então, vamos lá. No começo do texto lembrou alguma coisa que vocês já fizeram, não lembrou?

42. Gisele - No laboratório. Quando a gente foi no laboratório.

43. P - Isso, quando vocês foram no laboratório. Ficou alguma dúvida ainda?

44. Camila - Quando a gente fez o submarino encher e esvaziar.

45. P - Até aí vocês tiveram alguma dúvida? Foi bom para lembrar. Não deixou dúvida nenhuma? (09:24)

Uma pergunta de caráter instrutivo é enunciada pela professora no primeiro turno do episódio, com a intenção explícita de verificar o grau de apreensão das crianças sobre o conteúdo do texto lido. Não satisfeita com a resposta, detalha a pergunta no turno 31 , cuja resposta de um dos alunos traduz a síntese apresentada pelo texto sobre o modo de flutuar e afundar do submarino.

A mediação discursiva docente seguinte é mais uma pergunta que, embora também seja de instrução, tem um caráter mais aberto que a anterior, pois conduz os alunos à comparação do conteúdo do texto com conhecimentos apropriados em outras aulas ou em outros contextos: "Tinha alguma novidade para vocês? (...)". O significado da palavra "novidade" tem, em sua essência, o motivo docente explícito no objetivo de comparação, aliás, mais precisamente de levar os alunos a estabelecer relações. Com a relevância de se constituir como um significado, a palavra ou signo "novidade" torna-se a unidade do 
pensamento verbalizado pela professora, como tal realiza o papel de unidade da comunicação (Vigotski, 2009b; Bakhtin, 2010).

A mediação do turno 41 dá continuidade à explicitação desse motivo/objetivo docente, fornecendo elementos/signos de ativação da memória - o conteúdo do início do texto fez a aluna Gisele se lembrar das ações antecedentes realizadas no laboratório de ciências, complementada na enunciação da aluna Camila no turno 44, com a explicitação dessas ações.

Notamos que a professora medeia a relação com o aluno Everson, exigindo semântica na linguagem que compõe a resposta dada por ele no turno 34. Quem é o sujeito que descia? Na verdade, esse é o conteúdo da pergunta da professora - "Ele quem?”, cuja intenção pode ser a de ensinar o aluno a falar de modo que seus ouvintes o entendam.

Como já mencionamos na discussão do episódio anterior, levar os alunos a estabelecer relações é um motivo/objetivo presente em muitas mediações discursivas enunciadas por essa professora, como foi possível verificar no episódio anterior, posta em prática pelo recurso da analogia. Ao recorrermos ao conteúdo dialógico do encontro formativo, ocorrida na FEUSP no dia 27 de agosto de 2008, encontramos uma passagem, na qual a professora Verônica enuncia seus sentidos sobre esse modo de mediação.

\section{Episódio de formação - professora Verônica em situação de aprendizagem}

1. Form. I (...) Então eu gostaria de começar a discutir, a discutir não, a ouvir vocês sobre o trabalho de vocês na sala de aula, dando as atividades.

2. Silêncio

3. Form. I - Vamos, vamos... Quem é? Verônica... que eu tenho ouvido muito falar, não é por nada, não mas... é que ela tá gravando o seu, e ela fala da Verônica, que é a gravação dela...

4. Verônica - Bom, eu tenho gostado bastante, e uma coisa que eu tenho percebido nos alunos, que até então tinha uma dificuldade, a minha sala tinha muito, era de saber estabelecer relação. Que até que eu trabalhava um conteúdo, tentava puxar aquele conteúdo em outra disciplina e eles ficavam meio assim e eu tenho percebido que na sequência, acho que a Fernanda também concorda porque ela está filmando, ela deve também estar percebendo. Eles falam assim: Ah, que nem você falou na outra aula, que nem a gente viu em tal texto, eu tenho gostado muito disso, eles têm buscado referência do que eles já viram, que na minha sala não era comum.

5. Form. I - E Verônica, você acha que isso é por causa do conteúdo da atividade, da relação entre conteúdo, nós procuramos sempre relacionar mesmo. Ou é pela metodologia que eles falam mais e discutem mais na sala?

6. Verônica - Eu acho que são os dois, sinceramente, eu acho que são os dois. Que eu tenho a prática de sempre tentar relacionar uma aula com a outra, já, eu já vinha trabalhando isso, mas eu tinha uma dificuldade, que não faziam tanto, e depois das sequências eles conseguem mais, porque também deu certo de outras coisas que não estavam na sequência, nós trazermos outras atividades, que não estavam na sequência, e 
eles conseguiram, eles estão conseguindo muito isso, né? Ah, de tal coisa, de tal atividade, eles trazerem isso, e eu achei muito produtivo.

Este episódio formativo contém elementos que favorecem a discussão sobre o desenvolvimento profissional das professoras participantes, em especial da professora Verônica, o que justifica a sua inserção no processo de análise.

Referimo-nos à conversação estabelecida entre a formadora e professoras como uma situação típica de aprendizagem nos moldes vigotskianos, não apenas por se caracterizar como uma situação eminentemente social, ou melhor, como uma atividade conjunta, mas também pelo papel de tutora ou parceira mais experiente, desempenhado pela formadora (Edward e Mercer, 1988). O objetivo de saber como as atividades das sequências em aplicação na escola estavam sendo desenvolvidas, e como as próprias professoras avaliavam esse processo, explicita o seu papel de orientação e formação. No turno 05, a formadora detalha essa intenção, problematizando a enunciação da Verônica e levando-a a avaliar a qualidade das atividades das sequências, e a relacionar seu conteúdo, intenções, e proposta metodológica adotada, com o avanço na capacidade dos alunos em estabelecer relações.

Em resposta à enunciação da formadora, Verônica justifica o avanço de seus alunos como decorrente não apenas do conteúdo da proposta metodológica incorporada no desenvolvimento das sequências didáticas do LaPEF, e nem só do conteúdo das atividades que fazem parte dessas sequências, previamente planejadas com este objetivo, tal qual afirma a Form. I, mas também em sua iniciativa de sempre querer que seus alunos estabelecessem comparações, ao relacionarem conhecimentos novos em processo de compartilhamento na aula com outros trazidos de estudos realizados em outras aulas. Ilustra sua iniciativa, ao destacar a adoção desse modo de mediação, ainda que com dificuldades, em atividades e conteúdos que não fazem parte das sequências didáticas elaboradas pelo LaPEF.

Há coerência entre o motivo da professora "de sempre tentar relacionar uma aula com a outra”, por considerar o quanto essa relação é produtiva na aprendizagem de seus alunos, com o mesmo objetivo contido nos conteúdos da sequência didática, como já dissemos, explícito pela formadora I, ao enunciar que "nós procuramos sempre relacionar mesmo". Tal coerência mostra uma das possibilidades de contribuição da parceria colaborativa estabelecida entre a escola e o LaPEF para a criação de situações de aprendizagem coerentes com as necessidades formativas das professoras. No caso da 
professora Verônica, ela deseja não apenas aprender a fazer, mas também por em prática o seu aprendizado, relação que nos fala não somente de seu motivo, mas substancialmente de seus sentidos para com sua atividade pedagógica e também de formação - elemento de destaque favorável ao seu processo de desenvolvimento profissional.

Uma maior aproximação de nossa lente nos mostra outros elementos do processo de desenvolvimento profissional da professora Verônica. A referida enunciação no turno 06, em resposta à pergunta da formadora, além de nos falar das possíveis causas dos avanços no processo de aprendizagem dos alunos, de seus motivos e sentidos, nos mostra indícios de como ela está gradativamente dominando e se apropriando de signos, mediante os quais o seu motivo realiza-se no objetivo de levar seus alunos a estabelecer relações. Esses indícios aparecem em seu ato de assumir publicamente que, apesar de ter dificuldades, ela insiste em introduzir esse modo de mediação em sua linguagem mediacional. A palavra "sempre" demarca o caráter de insistência e o objetivo de permanência desse modo de mediação em suas ações mediadas estabelecidas no contínuo de sua atividade docente em sala de aula. Assumir dificuldades publicamente e o caráter de insistência flagrado em sua abordagem, nos falam não apenas da falta de domínio da professora, mas, sobretudo, da inter-relação que pode estar havendo entre seus processos de dominar ou saber usar o modo de mediação e o de se apropriar dele.

Para Werstch (1999), domínio e apropriação são processos diferenciados, embora possam se entrelaçar: dominar seria saber como usar um modo de mediação sem dificuldades; apropriar-se de algo, seria tomá-lo para si, fazendo-o seu. O domínio sobre determinado modo de mediação pode relacionar-se positivamente com sua apropriação pelo sujeito, o que favorecerá a sua permanência usando-o e tornando-o permanente em suas ações mediadas.

Portanto, ousamos sugerir que o entrelaçamento desses dois processos está em pleno acontecimento no plano do desenvolvimento profissional da professora Verônica. Ainda mais, não descartamos a possibilidade de que a situação de aprendizagem vivenciada por ela no encontro formativo tenha incidido sobre sua zona de desenvolvimento proximal e potencializado o desenvolvimento de funções psicológicas superiores favoráveis à apropriação do modo de mediação em análise, o que a levará a superar as dificuldades e a usálo com mais fluência em suas mediações discursivas.

Vale lembrar que, embora focalizemos o desenvolvimento profissional de apenas uma das professoras do coletivo docente da escola presentes no encontro formativo e participantes da parceria colaborativa, ela não é o único sujeito em aprendizagem, uma vez 
que assentamos esse coletivo e essa professora em um sistema coletivo de atividade composto por várias comunidades de aprendizagem. No episódio em análise, foi possível mostrar a inter-relação entre duas dessas comunidades - a sala de aula com o fórum formativo. Por conseguinte, colocamos a vista possíveis contatos e sobreposições entre múltiplas zonas de desenvolvimento proximal, a considerar os aprendizes participantes dos dois contextos. A ZDP de cada participante, seja aluno, professora ou formadora segue o seu ritmo, ainda que com suas particularidades, com potenciais para influenciar e ser influenciado pelas relações sociais das quais compartilha.

Todavia, Daniels (2003) nos lembra de que em tal situação não é possível ignorar o avanço na própria comunidade ou até do sistema do qual ela faz parte, por ocasião de modificações em um dos seus participantes. Para esse autor, a modificação no quadro de aprendizagem e desenvolvimento de um sujeito pode significar mudanças em todo o contexto, justificadas pelas atividades mediadas que o põem em movimento, tanto pelas intenções dos sujeitos como pelo instrumentos/signos interpostos por eles nas relações. Engestron (1999) e Daniels (2003) não nos deixam esquecer das tensões e contradições imanentes a essas atividades mediadas e nem o seu potencial em acarretar modificações no sujeito, na comunidade e no sistema coletivo de atividade.

Sendo assim, reafirmamos o não isolamento da professora Verônica em seus processos de apropriação e domínio sobre modos de mediação, isto é, em seu processo de desenvolvimento profissional. Ao comunicar suas dificuldades e seus modos de superação ao coletivo do qual faz parte, está atuando não apenas sobre a sua ZDP, mas sobre as dos demais participantes; as relações mediadas circunscritas às suas comunicações e aos demais modos de se inter-relacionar são condição essencial para estabelecer relações intermentais, consequentemente, para o processo de formação de suas funções psíquicas superiores.

Por fim, para finalizar a análise do episódio, estabelecemos relações entre a enunciação da professora no episódio formativo e sua mediação discursiva presenciada no episódio de ensino III, com a intenção de reafirmar a ideia antes esboçada de que o signo "novidade" contém como significado a necessidade de levar seus alunos a estabelecer comparações. A insistência da professora em perseguir na apropriação e domínio de tal modo de mediação, fala positivamente da relação de coerência que há entre seu motivo e objetivo inerente à sua ação com o motivo e objetivo da atividade de ensinar ciências para crianças. 
Por falar em insistência, notamos que a aluna Gisele não se esqueceu de sua pergunta, provavelmente não resolvida mediante a leitura proposta pela professora. Gisele repete sua pergunta na primeira enunciação do próximo episódio.

\section{Episódio de ensino IV - Qual o foco de atenção dos alunos na aula?}

(09min: 27seg) 45. Gisele - Para que servem as válvulas?

46. $\mathbf{P}$ - Isso, vamos para as perguntas? Em baixo tem a figura do submarino, não tem?

47. Alunos - Tem (em coro)

48. P - Eu pedi para o Yuri desenhar pra gente pra vocês imaginarem (...) Foi cortado mais ou menos o submarino, então vai ver essa parte de frente. Deu pra entender essa figura? (indica o corte do submarino com as mãos).

49. Alunos - Siiimm

54. $\mathbf{P}$ - O que deu para perceber é que foi a figura que trouxe mais informações para vocês nesse texto? Sim ou não?

55. Alunos - Siimm (em coro)

56. $\mathbf{P}$ - A primeira parte do texto não trouxe dúvida nenhuma? Nem um conhecimento novo?

57. Alunos - nãaoo (em coro)

58. P - Não? Todos concordam com que os colegas estão falando?

59. Alunos - Siimm (em coro)

60. P - Agora, a figura trouxe coisas novas? Conhecimentos novos? A primeira pergunta foi a do Felipe sobre o cilindro, né? Já foi explicado, você entendeu Felipe? Mais alguém? (10min: 24seg)

Neste episódio, há elementos que nos levam a sugerir que a professora percebe que a figura desenhada na lousa e o esquema do submarino representado no texto estão chamando mais a atenção dos alunos do que o texto explicativo. As perguntas enunciadas pela professora nos turnos 56 e 58 têm a intenção de verificar essa possiblidade, confirmada pelos alunos em suas respostas subsequentes. No turno 60, a enunciação da professora, embora tenha a forma indagativa, tem caráter de confirmação, cuja justificativa é apoiada na origem e autenticidade do conteúdo das perguntas dos alunos. A professora conclui que as perguntas dos alunos são baseadas nas imagens e esquemas, pois foram as figuras que trouxeram coisas novas e conhecimentos novos, enquanto que o texto não gerou nenhuma dúvida para eles. 
Há outro indício de contradição que é o fato da professora, mais uma vez, não responder e nem colocar em discussão a pergunta da Gisele sobre as válvulas. O que explica tal atitude? O assunto não é considerado relevante? Ou a resposta não está ao alcance da professora? Sugerimos que devemos esperar o fim da aula, pois quem sabe encontremos hipóteses mais plausíveis.

A aula continua nos fornecendo mais elementos para sugerirmos que o foco de atenção dos alunos difere, em certa medida, do objetivo central da professora, ou pelo menos, pode ter sido alterado com o processo de leitura. Vamos ver o que nos informa o próximo episódio. Podemos adiantar que mais uma criança, de braço erguido, espera concessão de espaço na conversação.

\section{Episódio de ensino V - pergunta autêntica como ponto de inflexão na conversação}

(10min: 26seg) 61. Camila - O que é tanque de lastro?

62. P - Tanque de lastro?? (surpresa) Com a leitura do texto não deu para entender? Ninguém entendeu para explicar para o colega? O que tem aí no desenho sobre o tanque de lastro?

63. Camila - Tem água no tanque.

64. $\mathbf{P}$ - Isso. Esse tanque de lastro serve para armazenar o quê?

65. Alunos - Água (em coro)

66. $\mathbf{P}$ - Água.

67. Paulo - É a mesma coisa que o pulmão.

68. P - Oi? Pulmão armazena água?

69. Alunos - Não. Armazena ar.

70. P - Isso. Então esse tanque de lastro é o lugar onde fica a ... (as crianças falam em coro "água") água do submarino (repete). Pra que fica essa água aí?

71. Alunos - Para o submarino descer.

72. P - Isso. Entenderam então o que é o tanque de lastro? Qual é a sua dúvida Gisele? (11min: 26seg)

A pergunta da Camila no turno 61 surpreende a professora a levando a recorrer mais uma vez à leitura do texto como fonte de respostas. Aliás, ela recorre não apenas ao texto, mas também à figura que o compõe e às interpretações dos alunos, como signos mediadores da conversa. 
Não é difícil notar que as relações de poder e autoridade estão um pouco alteradas nesta aula, basta focalizarmos no conteúdo do movimento discursivo. As perguntas autênticas e enunciações dos alunos imprimem novas características à conversação. Podemos até sugerir que a pergunta da Camila sobre o que é tanque de lastro (no turno 61), gerou um ponto de inflexão, flagrado no tom de surpresa da voz da professora ao repetir a pergunta no turno seguinte e ao solicitar, mediante uma indagação, se "ninguém entendeu para explicar para o colega?".

Tal afirmativa é baseada em estudos de Werstch (1999), os quais sugerem que, ao analisarmos uma conversação, nos atentemos não apenas para o sujeito ou agente, mas também para a qualidade das ferramentas culturais, denominação dada por ele aos modos de mediação ou aos signos/instrumentos que, integrados ao sujeito, compõem a ação mediada. Werstch (1999, p. 110) afirma:

Quando tratamos de descrever o poder e a autoridade, as perspectivas centradas no agente tem evidentemente um grande atrativo. Entretanto, se não consideramos o papel dos modos de mediação, tais perspectivas apresentam resultados deficientes. (...) As ferramentas culturais não operam por si mesmas, porém podem ter um forte efeito sobre a dinâmica da ação humana, incluindo as relações de poder e autoridade envolvidas.

A professora e alunos são os sujeitos das ações mediadas presenciadas na atividade de ensino e de aprendizagem em análise, configuradas pela presença da linguagem e ações desses sujeitos como signos intermediadores. A nossa atenção está centrada não apenas nesses sujeitos, mas também nos signos que a eles se integram para compor o conjunto de ações mediadas. A inferência sobre a possibilidade de existência de ponto de inflexão na sequência das falas origina-se exatamente dessa centralidade de nossa atenção, sem deixar de considerar a inter-relação entre essas ações mediadas - elemento essencial revelador da fluência do movimento dialógico discursivo. O conceito de dialogia é mais uma vez ressaltado, tal como é abordado por Bakhtin (2010), como um encontro de enunciações, em que uma voz determina o conteúdo da outra, em que uma se apoia na outra. Apropriamos das palavras desse autor (2010, p.217) para reiterar a ideia de que "a palavra é o território comum do locutor e interlocutor".

O fato de abordarmos o movimento discursivo em pauta tal qual uma dialogia, pressuposto que direciona a nossa atenção para todas as enunciações, nos leva a destacar o caráter autêntico da pergunta da Camila como uma enunciação que altera as relações de poder 
e alteridade da conversação. Se essas relações fossem representadas em uma reta ou em uma curva, na qual estivesse a professora posicionada de um lado e os alunos do outro, teríamos agora que mudar o ponto representativo do poder e autoridade, afastando-o um pouco da professora e aproximando-o do lado dos alunos. Lógico, não se trata de uma relação causal direta entre a pergunta da aluna e a autoridade da professora, pois tal alteração só foi possível por se tratar de uma dialogia, porque a qualidade do conteúdo do discurso da professora abriu espaços para alterações hierárquicas, exatamente por já existir espaços para a contínua voz da criança. Referenciamo-nos mais uma vez em Bakhtin (2010) para qualificar esse discurso como internamente persuasivo, cuja posição no movimento discursivo não é a de aceitar ou rejeitar as palavras alheias, mas de assegurar um diálogo com envolvimento dialógico entre os participantes.

No caso do envolvimento dialógico que estamos assistindo com a análise do episódio $\mathrm{V}$, notamos que, embora consideremos a ocorrência da inflexão na conversação, aparente no tom de surpresa contido na voz da professora, imediatamente depois o poder é retomado e parcialmente compartilhado. Esse parcial compartilhamento de poder é demarcado nas demais enunciações da professora, compostas ora por perguntas instrutivas, ora pela repetição da resposta com tom avaliativo, ora pela solicitação de complementos, seguida pela repetição das respostas. Em uma conversação regida pelo padrão triádrico, repetir a resposta do aluno pode significar avaliá-la positivamente ou negativamente, a depender da entonação da voz do falante: no turno 66, a professora repete "água" em tom afirmativo; no turno 68, a resposta do aluno é repetida em tom indagativo, o que aqui manifesta o descontentamento de quem ouviu e avaliou negativamente.

Talvez a referida inflexão e suposta solução pautada no compartilhamento parcial de poder, e as demais inflexões que ocorrem até o final da aula, decorram da suposta distância entre o objetivo docente e o objetivo dos alunos. Talvez a atenção da professora, ao planejar e preparar suas mediações para a aula em curso estivesse centrada apenas no conteúdo do texto, cuja centralidade está na explicação sobre a emersão e submersão do protótipo de submarino, sem se ater às partes indicadas na figura que compõe o texto e nem ao funcionamento do submarino de verdade, identificado pelos alunos como submarino "Nautillus",15.

\footnotetext{
${ }^{15}$ Nautillus é o submarino da obra literária "Vinte mil léguas submarinas" de autoria de Júlio Verne, cuja versão infanto-juvenil, lida e discutida com os alunos na introdução da sequência didática, foi adaptada pelo escritor Edson Rocha Braga e publicada pela editora Scipione em 2004.
} 
A qualidade das perguntas, bem como o grande envolvimento e participação dos alunos na conversação, mostram que no foco de estudo deles, o submarino está completamente inserido em seu contexto natural, ou melhor, em seu contexto de funcionamento - o fundo do mar. O contexto mental criado na aula e na mente dos participantes extrapolou tanto o conteúdo do texto explicativo, como o contexto físico e espacial do submarino simulado por uma garrafa de plástico submerso no balde, recipiente que cumpriu o papel do mar ao longo da experimentação. A nosso ver, os alunos superaram esses contextos e querem ir adiante e aprender sobre o submarino de verdade, emerso, submerso e em deslocamento, com previsão até de possíveis colisões, como veremos no decurso dos próximos episódios.

Se olhássemos a classe neste momento, veríamos que a Gisele está de braço erguido novamente. Será que ela vai repetir a sua pergunta ou será uma nova dúvida?

\section{Episódio de ensino VI - uma descontinuidade na conversação: para que serve as válvulas do submarino?}

(11min: 27seg) 73. Gisele - Para que servem as válvulas?

74. $\mathbf{P}$ - Pra que serve as válvulas?

75. Yuri - Para controlar o submarino

76. $\mathbf{P}$ - Controlar o ...

77. Alunos - Submarino (em coro)

78. P - Aqui por essas válvulas (aponta para a figura que está no texto) elas controlam como, Yuri?

79. Yuri - Eu sei, elas controlam enchendo as partes do submarino.

80. $\mathbf{P}$ - Enchendo o...

81. Alunos - Submarino (em coro)

82. $\mathbf{P}$ - É isso? E como que vocês descobriram isso? Me expliquem. Vocês já sabiam ou o texto explicou isso pra vocês? Onde o texto explicou? Mostre pra gente? Alguém grifou essa parte do texto? Vamos tentar procurar? Vou ler agora em voz alta com vocês. Vou ler a partir da figura, tudo bem? (começa a leitura em voz alta): "Mas vocês se lembram de por que isso acontece? Quando o submarino está cheio de água, ele está pesado e vai lá pro fundo do balde, mas quando a gente tira toda a água e deixa só o ar, ele fica mais leve e sobe". (12min: 44seg)

Finalmente a pergunta da Gisele, repetida pela terceira vez no turno 73, é pautada pela professora. Talvez, essa distância notada entre a reiterada pergunta da Gisele e a 
mediação docente, seja explicada pela contradição entre os objetivos referenciados acima ou porque a professora não sabia de prontidão a resposta, uma vez que o texto não contém diretamente esse conteúdo. Mais uma vez, a professora se vale de seu jeito de mediar a conversação, se apoiando, ora em suas perguntas e ou palavras de complemento, ora nas respostas dos alunos, ora no conteúdo do texto em estudo, compartilhando parcialmente ou totalmente o poder na conversação. No caso do funcionamento das válvulas do submarino, embora os alunos tenham suposto o controle como resposta, se posicionando naquele momento como uma voz colaboradora para o compartilhamento de informações, não houve uma compreensão satisfatória a respeito, nem mesmo com a continuidade da leitura orientada pela professora. A leitura destaca o afundar e flutuar do submarino sem se referir ao papel do tanque de lastro nesse processo, o que caracteriza uma descontinuidade entre o conteúdo das enunciações e o do texto lido.

Apesar do aparente desencontro, a conversação prossegue sem nenhum indício de mudança na qualidade do discurso docente. A classe, se vista de cima, mostraria uma imagem de pessoas conversando entre si, sem alteração de voz, sem pedidos de silêncio, sem brincadeiras paralelas: ora fala a professora, ora fala cada criança, ora fala muitas crianças ao mesmo tempo. Neste instante, a voz está com uma criança - será mais uma pergunta autêntica? Sim, estamos diante de mais uma pergunta de criança.

\section{Episódio de ensino VII - pergunta autêntica gera compartilhamento de informações}

(16min: 16seg.) 116. Rafael - Se tiver uma rocha assim e o submarino estiver para bater, ele pode até virar com o volante assim? (representações com gestos).

117. $\mathbf{P}$ - O que vocês acham?

118. Alunos - Que sim.

119. P - Lógico que controla.

120. Wallace - Antes não tinha a tecnologia que tem agora, agora é tudo moderno.

122. Camila - Antes era de madeira, um tipo de madeira.

123. $\mathbf{P}$ - (surpresa) o submarino???

124. Alunos - Não, o volante. (em coro).

125. P - Quem sabe o nome que eles estão dando para o volante? Volante tem no carro, será que no submarino é o mesmo nome?

126. Alunos - Nãooo (em coro). 
127. P - Qual é?

128. Paulo - Controlador.

129. $\mathbf{P}$ - Controlador, quem pensa em outro nome?

130. Amanda - Controle.

131. P - Controle ... (espera complementos).

132. Yuri - Guidão.

133. P - Guidão. Quem tem algum nome? Mais ninguém? Aquilo no navio se chama timão ou leme, tá? Mas depois a gente vai ver. Podemos continuar aqui no texto?

(17min: 39seg.)

Não houve inflexão de fala na conversação deste episódio. Há indicativas de que a professora sabia com prontidão a resposta, signo mediacional que a possibilitou reposicionar as relações de poder e autoridade e gerir com mais fluidez a conversação até o compartilhamento da nova informação. No caso da pergunta do Rafael no turno 116, a professora não a responde de imediato, opta por devolvê-la à classe e vai compondo a informação, captando e repetindo respostas, solicitando complementos, de modo a aproximar os alunos do verdadeiro nome da peça que permite que o submarino seja desviado de possíveis obstáculos.

O domínio da professora sobre o movimento discursivo e sobre o conteúdo em discussão aparece na mediação do turno 125, composta por uma pergunta ("Quem sabe o nome que eles estão dando para o volante?"), cuja resposta já é sabida por ela, o que garantiu as idas e vindas de suas enunciações avaliativas sobre as enunciações dos alunos. $\mathrm{O}$ tom de pausa de sua fala, ao repetir as respostas dos alunos, indica que a resposta está errada ou incompleta e que os alunos devem continuar tentando responder.

Talvez possamos dizer que dessa vez houve "traspasso", denominação dada por Edwards e Mercer (1988) ao processo de transferência de conhecimentos do professor, isto é, do adulto mais experiente para os alunos. Traspasso, traduzido no compartilhamento de conhecimentos, justificado pelo fato de agora pelo menos 35 pessoas saberem o que antes apenas uma sabia (idem, 1988). A nova informação foi compartilhada sob orientação e colaboração da professora.

Entretanto, o mesmo não acontece no próximo episódio. A professora é surpreendida com mais uma pergunta autêntica, dessa vez sem resposta conhecida. 


\section{Episódio VII - mais perguntas autênticas, mais pontos de inflexão no movimento discursivo}

(18min: 33seg.) 143. Rafael - O submarino precisa de gasolina?

144. P - O submarino precisa de gasolina!? (surpresa).

145. Alunos - Nãao (em coro).

146. Alguns alunos - precisa de ar.

147. Felipe - De gás.

148. Vitor - Ele precisa de água e ar.

149. Andreza - Água e ar.

150. P - Oi? Água e ar. Nós não acabamos de ver isso nesse texto? E vocês não viram na experiência? Para ele subir o que que eu faço?

151. Alunos - De ar. A gente assopra e água sai, e o ar entra, e ele sobe.

152. Yuri - Pra descer precisa de água.

153. P - Isso. E aí a pergunta do Vitor? (aponta para o Vítor)

154. Vitor - Mas como que ele anda?

155. Camila - Precisa da hélice

156. $\mathbf{P}$ - Só da hélice (olha para o desenho da lousa)

157. Vitor - Não, mas como ele anda? Ele não é assim ... (Vitor repete sua pergunta para lembrar a professora que ele não está se referindo à emersão e à submersão do submarino, mas ao seu modo de deslocamento).

158. P - Boa pergunta... (a professora sorri) pra andar ele não é movido a ar e nem a água... será que ele precisa de gasolina? Vamos pesquisar isso?

160. P - As dúvidas que esse texto não respondeu, vamos anotar? O que vocês acham? Vou anotar na lousa, mas não precisam copiar agora. As dúvidas que esse texto não respondeu e que nos vamos pesquisar. Fala Rafael. Qual é a sua dúvida? É se ele precisa de gasolina? (Começa a escrever na lousa). (20min:06seg)

Não há dúvida de que as perguntas do Rafael, no turno 143, e a do Vitor, no turno 154, compõem o ponto de inflexão que mais arrastou as relações de poder e autoridade para o lado dos alunos no curso da aula. A professora repete a pergunta do Rafael em um tom que mescla indagação e exclamação, provavelmente porque à resposta cabe muito mais do que um sim ou um não, mas a informação de como o submarino se movimenta no mar. A princípio ela pôs em discussão o conteúdo central da aula e do texto, o subir e o descer do submarino, utilizando para tanto o ar e a água, respectivamente, dando continuidade em seu foco de ensino. Entretanto, as enunciações dos alunos nos dizem que esse conteúdo já está compartilhado entre eles. Esse compartilhamento é confirmado pela professora em sua 
enunciação no turno 150 e referendado pelos alunos nos turnos seguintes, ao repetirem as relações que explicam o afundar e o flutuar do submarino. Entretanto, o que Vitor não sabe e insiste em saber é como o submarino anda, ou seja, como ele se desloca horizontalmente na água do mar.

A ênfase explicativa dada por Vitor no turno 157 à sua vontade de saber, ao dizer “Não, mas como ele [submarino] anda?", leva a professora a, de repente, perceber a qualidade da pergunta do aluno e a contradição que há entre o seu entendimento sobre o conteúdo da pergunta dos alunos Vitor e Rafael com o real conteúdo dessas perguntas. Essa percepção a faz assumir publicamente, ainda que não explicitamente, que não sabe se o submarino precisa de gasolina e nem como ele se desloca. A qualidade das perguntas é reconhecida não por serem realmente boas, mas, sobretudo por suscitarem informações que nem ela e nem o texto contemplam. Resta-lhe convidar a classe para pesquisar a respeito: "as dúvidas que esse texto não respondeu, nós vamos pesquisar". Imediatamente ela vai para a lousa e solicita que os alunos repitam suas perguntas, as quais vão sendo registradas por ela na lousa.

Enquanto a professora vai escrevendo, os alunos conversam entre si sobre o funcionamento do submarino. Eles falam em periscópio, como instrumento que permite o comandante "ver a superfície"; em modos de orientação do submarino, como bússola, rastreador, GPS. Para finalizar, Rafael faz mais uma pergunta sem resposta: "Será que tem piloto automático?”. Embora estivesse escrevendo na lousa, a professora estava atenta à conversação dos alunos e anota as dúvidas surgidas nessa conversa. Ao ouvir a pergunta do Rafael, retoma a mediação e diz:

\section{Episódio VIII - partilha de compromisso na busca de respostas}

(23min: 00) 183. P - Piloto automático? Vamos ver. Mais alguma dúvida?

184. Alunos - Nãooo (em coro)

185. P - Então, está ótimo. Então, nós vamos fazer o seguinte. Hoje nós terminamos de ler esse texto. Agora eu vou pedir para que vocês abram o caderno de ciências e todos vão registrar as dúvidas que ficaram a partir da leitura. E aí nós vamos buscar respostas para essas dúvidas, o que vocês acham? Tudo bem? Então o nosso compromisso para a próxima aula é buscar respostas para essas dúvidas que ficaram. (24min: 06seg) 
Não notamos nenhum sinal de constrangimento da professora por não ter respostas prontas para as perguntas dos alunos. É importante salientar que o reconhecimento da ausência de conteúdos para discutir as últimas perguntas aparece acompanhado de uma decisão sobre o próximo passo, o de pesquisar, o qual deveria ser assumido na qualidade de um compromisso não apenas por ela, mas por todos os participantes. A continuidade contextual estava sendo garantida para aula seguinte por meio dessa decisão da professora.

Podemos interpretar tal modo de mediação não apenas como uma partilha de responsabilidades, mas, principalmente, como uma partilha na posse dos conhecimentos. $\mathrm{O}$ conteúdo discursivo dessa mediação bem pode ser a expressão de uma concepção sobre o ensino, a de que o professor não deve procurar respostas sozinho, pois os conhecimentos não são apenas seus; a de que os alunos, embora ainda sejam crianças, são sujeitos com responsabilidades sobre a busca e compartilhamento de conhecimentos na aula. Ousamos também ao dizer que as concepções enunciadas pela professora combinadas à relação de alteridade estabelecida entre ela e os alunos, podem ser entendidas como um importante indício favorável ao seu desenvolvimento profissional, por abrir espaços tanto para a superação de suas necessidades formativas transparecidas ao longo da aula, como para promover a criação de atividades conjuntas entre ela e seus alunos, nesse instante, seus interlocutores.

O fato de a professora assumir a ausência de respostas para quase todas as perguntas autênticas enunciadas pelas crianças, indica o vazio de vozes em sua memória que colaborassem com a solução de seus problemas. Ainda assim, sem a presença física e virtual de um parceiro mais experiente, a nosso ver, a aula se configurou como uma situação de aprendizagem da docência, pois as enunciações dos alunos atuaram sob diferentes aspectos na formação da professora, exigindo mediações qualitativamente diferentes: decisões rápidas, com apoio ou não de suas vozes interiores; alterações ou complementos em seu objetivo para adequá-lo aos dos alunos; revelou necessidades formativas, o que, certamente, impeliu a professora a procurar apoio para a aula seguinte.

A sugestão de que a professora buscará apoio para compor a aula seguinte, advém do nosso conhecimento sobre sua trajetória formativa e profissional. A predisposição ao estudo e à auto formação são elementos que fazem parte dos sentidos atribuídos por ela à sua atividade pedagógica no decurso de sua experiência como docente. E foi exatamente isso que aconteceu: a situação de aprendizagem iniciada na aula continuou com as pesquisas feitas pela professora para se preparar e retomar as discussões sobre o submarino com seus alunos na aula seguinte. 
Esse processo foi confirmado com o seu comentário sobre a aula no fórum formativo ocorrido na escola no dia 13/05/2008. Ela comentou especificamente sobre o modo como finalizou a aula: "anotei na lousa todas as dúvidas, falei: então nós vamos procurar outro texto e aí eu até pensei: eu vou ter que pesquisar, né? Mas aí eu li a história do submarino, então eu pulei a sequência...".

A professora cumpre o seu compromisso, pois na aula seguinte ocorrida no dia 16 de abril de 2008, ela retoma a discussão das dúvidas por meio da leitura e discussão de um texto, sobre a história do submarino.

Assim começou a aula seguinte:

$\mathrm{P}$ - (...) o que nós vamos fazer $4^{\circ}$ ano, vocês estão lembrados da última aula quando nós lemos um texto informativo sobre o submarino? Surgiram 06 dúvidas, estão lembrados? (...) Nós vamos agora ler antes as dúvidas que foram levantadas na última aula. Depois das dúvidas, a prô vai entregar um texto e a gente vai ver se esse texto responde as dúvidas e se nos ensina mais alguma coisa (...).

Após dezenove minutos de aula, a professora finaliza a leitura e discussão com abordagem sobre respostas às perguntas dos alunos, principalmente sobre o tanque de lastro e tipos de combustíveis usados para por o submarino em movimento. Em seguida, a pedido da professora, os alunos releem o texto e escrevem as respostas das perguntas em seus cadernos.

Vale destacar o modo como interpretamos o significado das últimas palavras da enunciação da professora: a coerência que há entre o assumir o compromisso coletivo pela busca de respostas e o significado da expressão “(...) a gente vai ver se esse texto responde as dúvidas e se nos ensina mais alguma coisa (...)" (grifos nossos). Tal coerência reforça a discussão feita anteriormente acerca das concepções de ensino explícitas sobre a partilha de poder e de conhecimentos, assumidas no corpo desta tese como indícios do processo de desenvolvimento profissional da professora Verônica.

Outro aspecto a ressaltar é que esse texto adotado pela professora, intitulado "história do submarino", é o último da sequência didática "o submarino", proposto pela equipe do LaPEF para conclusão dos estudos. A professora pulou a sequência, tal como ela própria afirma em seu depoimento citado acima, proferido no fórum formativo realizado no dia 13/05/2008. Há aqui mais um cruzamento entre o modo geral de ação docente, o conteúdo introduzido na escola pela parceria e o fórum formativo. Certamente, a decisão em adotar o referido texto exigiu que a professora revisitasse o conteúdo de toda a sequência para nela encontrar respostas que satisfizessem suas necessidades. Essa decisão foi comunicada pela 
professora ao coletivo, como já foi mencionado, o que referenda mais uma vez a sua inserção no sistema coletivo de atividade.

Por fim, para finalizar a análise da aula "para cima e para o fundo com o submarino", apresentamos dois mapas: o primeiro, uma síntese geral do fluxo de mediações discursivas docentes, que nos possibilita visualizar a totalidade dos objetivos intrínsecos a cada enunciação e ação da professora. Estabelecemos relações entre a realização do motivo/objetivo docente circunscrito ao fluxo da aula e a dialogia estabelecida com os alunos, como elemento importante no processo de desenvolvimento profissional docente; o segundo mapa tem a intenção de mostrar o padrão temático da classe ou o conjunto de compreensões compartilhadas por meio das mediações docentes combinadas às enunciações das crianças. Indagamos, portanto: podemos considerar essa aula como uma oportunidade de aprendizagem para os alunos, tal qual a professora pretendia criar?

Não ousamos responder essa indagação com prontidão, entretanto levantamos alguns elementos que nos levam a supor que o motivo ou o objetivo docente foi realizado e materializado sob diferentes signos. Vejamos o quadro abaixo com o conjunto de objetivos intrínsecos às mediações discursivas docentes.

Figura 09 - Mediações discursivas docentes e objetivos na aula "para cima e para baixo com o submarino".

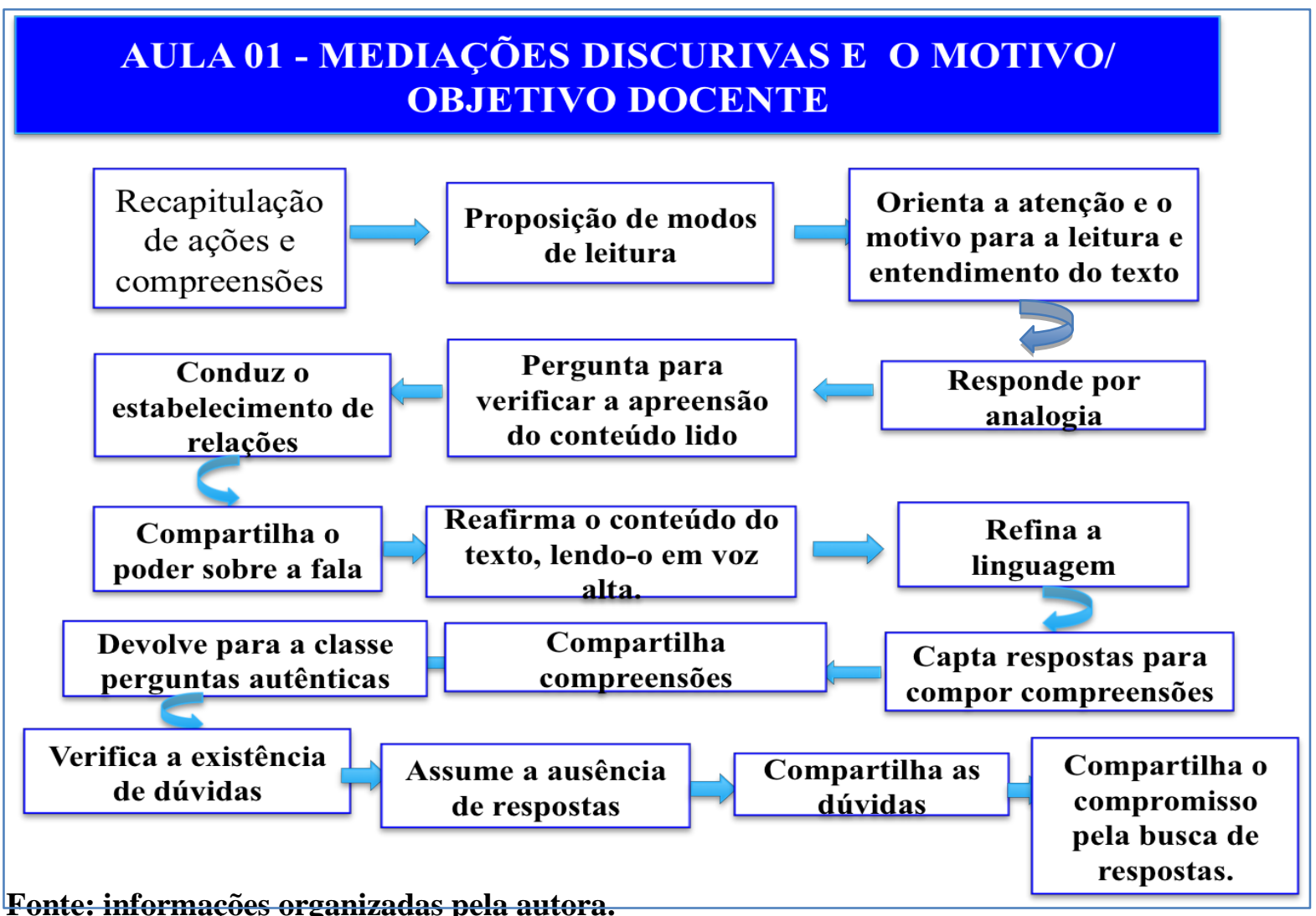


Esses objetivos intrínsecos às mediações discursivas são correlacionados ao que chamamos de objeto docente - objetivo da atividade pedagógica da professora. O objeto da atividade é alcançado com a realização de cada objetivo emanado de cada mediação discursiva. Esse objeto docente está representado nos signos e/ou instrumentos interpostos entre a professora e a aprendizagem das crianças. Lembramos, porém, que a realização do objetivo/motivo da professora não depende apenas de sua vontade, nem das vozes contidas em sua memória e nem dos signos ou modos de mediação adotados, mas também dos signos inseridos pelas crianças na conversação. Embora esses signos não estejam explícitos no quadro, o fluxo discursivo presenciado na aula nos diz dos seus potenciais como elementos que influenciam a mediação docente.

Aliás, a participação das crianças foi um traço peculiar nessa aula, marcante, sobretudo, por complementar o objetivo da professora no que diz respeito à construção do padrão temático, construído pelo compartilhamento de compreensões. É possível visualizar essa influência no conteúdo do padrão temático exposto no mapa seguinte:

Figura 10 - Padrão temático da aula "para cima e para baixo com o submarino".

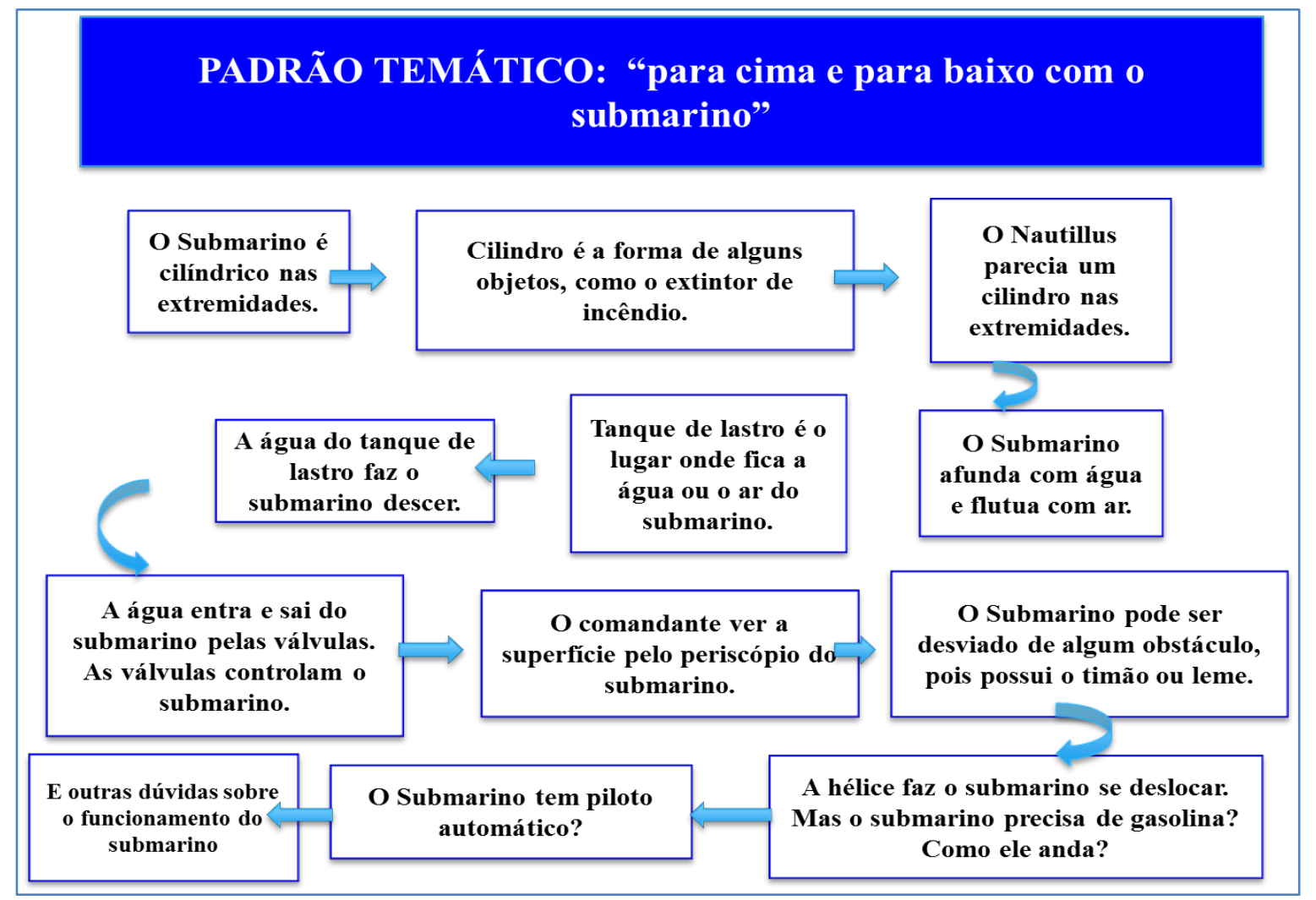

Fonte: informações organizadas pela autora 
O padrão temático fala da realização do objetivo docente relacionado à introdução da linguagem cientifica, isto é, ao objetivo de ensinar a falar ciências e ao de compartilhar conhecimentos ou compreensões, portanto, relacionados à apropriação de significados pelas crianças. Entretanto, estamos atentos ao fato de que não foi apenas a professora o único sujeito a introduzir e compartilhar conhecimentos, uma vez que os alunos cumpriram esse papel mediante suas enunciações. O compartilhamento de compreensões, um significativo objetivo da aula, se concebida como uma situação de aprendizagem ocorreu em virtude de diferentes signos/instrumentos ou modos de mediação, ora interpostos pela professora, ora interpostos pelos alunos.

Além das compreensões compartilhadas, destacamos a relevância das perguntas autênticas das crianças como signos a mostrar a materialização do motivo da professora no processo de ensino aprendizagem. A qualidade das perguntas tem uma relação direta com o estágio de aprendizagem dos sujeitos, pois a dúvida assenta-se sobre determinado pilar de conhecimentos. Na aula analisada, contabilizamos 08 perguntas autênticas enunciadas pelos alunos, assentadas sobre o conteúdo em estudo, portanto, motivadas por curiosidades epistemológicas.

A pergunta guarda o motivo, a vontade de querer saber mais, o que impele o sujeito a buscar respostas. Essa afirmativa nos faz lembrar o que já foi dito por vários autores, entre eles Antonio Faundez e Paulo Freire (1985, p. 46), sobre a conotação epistemológica que pode ter a pergunta, ao afirmarem que todo conhecimento começa pela pergunta, pela curiosidade, pois "a curiosidade é uma pergunta"; “[...] somente a partir de perguntas é que se deve sair em busca de respostas, e não o contrário".

Merece destaque o fato de que algumas das perguntas de cunho epistemológico das crianças foram compartilhadas como dúvidas por todos, inclusive pela professora. Essas dúvidas ganham o status de motivo, por impelir os sujeitos, principalmente a professora, a buscar respostas. Embora, professora e alunos, tenham assumido conjuntamente o compromisso por essa busca, o motivo, traduzido sob a forma de responsabilidade, impele com mais força a professora, por ser ela a adulta ou a parceira com mais experiência, pronto a colaborar e a gerir o processo de aprendizagem.

Em acordo com Faundez e Freire (1985), não negamos a ideia de que quem busca respostas a perguntas, aprende. Essa máxima vale também para o processo de aprendizagem 
da professora Verônica - sujeito que, uma vez impelido pelo motivo de garantir mais situações de aprendizagem para seus alunos, transforma a necessidade contida nas perguntas não respondidas por ela, em um novo problema de ensino, cuja solução garante sua melhor e maior formação em relação aos conhecimentos específicos da área em estudo.

Ousamos afirmar que a aula em análise se constituiu como uma situação de aprendizagem para alunos e professora e que a sala de aula da professora Verônica, inserida no sistema multivocal, consolida-se como uma comunidade de aprendizagem. Em tal comunidade, a palavra se realiza como "modo mais puro e sensível de relação social", expressa nas tantas vozes proferidas, ouvidas e consideradas (Bakhtin, 2010, p. 36). Flagra-se um engajamento dialógico, o que valida o compartilhamento de compreensões, informações, dúvidas e responsabilidades pela busca de respostas, como ações próprias de uma comunidade de aprendizagem.

Referimo-nos à comunidade de aprendizagem como um sistema social composto pelas atividades, na qual seus sujeitos estão inseridos. Inserir-se em uma atividade, ou melhor, estar em atividade é condição para que determinadas vivências se realizem como de aprendizagem e que aumente seu potencial de incidência sobre as múltiplas ZDPs. Na comunidade de aprendizagem referida, os motivos docentes foram realizados e materializados em significados apropriados pelos alunos; e em sentidos atribuídos pela professora à sua atividade pedagógica - sentidos, reforçados e renovados, tonificam com novas cores o seu processo de desenvolvimento profissional, a levando a se posicionar, cada vez mais, no campo da docência como práxis, ou seja, na direção contrária ao campo prescrito pela alienação.

\section{Continuidade contextual para a análise da próxima aula}

Os estudos sobre a emersão e submersão do submarino duraram cerca de dois meses. Após a leitura e discussão do texto "História do Submarino"", professora e alunos realizaram pesquisas orientadas na internet a fim de complementar as informações surgidas como necessidades nos processos de aprendizagem. A vida no fundo do mar tornou-se o centro de atenção dos estudos, com ações e conteúdos que abordaram desde diferenças entre as zonas oceânicas à caracterização da biodiversidade da flora e fauna de cada zona.

\footnotetext{
${ }^{16}$ Texto que faz parte da sequência didática “o submarino" (vide nota de rodapé no 14 ).
} 
A conclusão desses estudos criou contexto para o início do módulo de ensino seguinte: "Navegação e Meio Ambiente"," com abordagem sobre a flutuação de corpos, tipos de embarcações e outros conteúdos relacionados à vida marinha que habita a água de lastro dos navios e suas influências sobre a biodiversidade do ecossistema marinho. Para análise, privilegiamos uma das ações da Sequência Didática, intitulada "o barquinho"18, cujo foco conceitual é a discussão das principais variáveis que explicam a flutuação de corpos.

No dia 04 de junho de 2008, professora e alunos se encontram no laboratório de ciências com seus respectivos desafios de ensino e de aprendizagem. A um só tempo, a professora Verônica medeia a resolução do problema de aprendizagem e alunos buscam resolvê-lo. Organizados em grupo de quatro, alunos manuseiam papel alumínio e arruelas de ferro sobre a água colocada em uma larga bacia, a fim de saber "como construir um barquinho capaz de carregar o maior número possível de pecinhas sem afundar na água?”. Verônica circula pelas mesas com orientações e dicas, principalmente para grupos que insistem em construir o barquinho chamado "dobradura", aquele que tem um cone no centro, cujo formato dificulta seu equilíbrio na água e o transporte das arruelas. A experimentação não durou mais que 15 minutos, finalizada com a satisfação geral: todas as crianças conseguiram construir o barquinho com formato de balsa, capaz de transportar muitas arruelas, sem afundar.

Finalizada a experimentação, professora e alunos se dirigem para a sala de aula, onde as carteiras estavam em círculo, organizadas para uma roda de conversa. O tempo transcorrido entre a chegada à sala de aula até o início da conversação foi o necessário para que os participantes se sentassem, pois o porquê e a finalidade de tal organização espacial já haviam sido informados.

A proposta e orientação para que o espaço da sala de aula fosse organizado de tal maneira foram discutidas em encontros formativos. É o que podemos presenciar na seguinte conversação, extraída do fórum formativo ocorrido na escola em 27 de maio de 2008, no qual a coordenadora da escola e a formadora da universidade explicitam a necessidade de reversibilidade na organização dos espaços para realização de diferentes aulas.

\section{Episódio de formação - organização espacial da classe (27/05/2008)}

\footnotetext{
${ }^{17}$ Módulo de ensino publicado no livro didático: Coleção Investigar e aprender ciências - $4^{\text {o }}$ ano, São Paulo, Editora Sarandi, 2011. Autores: Carvalho, A. M. P.; Oliveira, C.; Sasseron, L. H.; Sedano, L.; Batistoni, M. elaborada pela equipe de pesquisadores participantes da parceria estabelecida com a escola.

${ }^{18}$ Idem nota de $\mathrm{n}^{\mathrm{o}} 17$.
} 
58. Coord. - (...) uma coisa também que é difícil é você ter aquela mobilidade pra fazer o trabalho em grupo e depois a conversa com outra organização de espaço. O submarino mesmo, o que a gente fez? Nós arrumamos o laboratório assim, as cadeiras em círculo e as mesas soltas, eles faziam as atividades em pé e depois sentavam. Mas o barquinho não dá para fazer em pé, então vamos ter que ter paciência para organizar, desorganizar e organizar de novo.

61. Form. II - Isso que a coordenadora está dizendo é de extrema importância, porque, temos percebido que quando não se desmonta o grupo, o pequeno grupo, e não faz uma roda geral a discussão não se torna muito efetiva. Ela pode ser para um aluno, de um grupo, porque ele acaba sendo a cabeça daquele grupo e ele vai falar e o resto já se sente como se tivesse contribuído, porque no meu grupo já falaram, agora quando está ali na roda todo mundo é dono de si, então se a professora pediu para eu dar minha opinião, eu tenho que dar minha opinião, é uma nuance diferente. Então esse cuidado para organizar a sala para eles fazerem as atividades e depois disso organizados, desmembrar os grupos para cada um dar a sua opinião, é importante.

O que foi dito pela coordenadora, enfatizado e ampliado pela formadora contempla orientações metodológicas de cunho organizativo no âmbito espacial da classe, com repercussões sobre o compartilhamento do poder sobre a fala. A orientação é clara: é importante desmembrar o grupo para que cada aluno tenha garantido espaço para falar e determinado poder sobre sua própria enunciação. Caso permanecessem em grupo, correr-se-ia o risco de apenas um falar em nome dos participantes.

O alerta da formadora dirige-se para a mediação docente, pois é a professora em seu papel de mediar a gestão da classe que garante o fluxo do movimento dialógico discursivo, com garantia de espaços para todas as vozes. Entretanto, ao se conversar em círculo, uns de frente para os outros, a comunicação e a dialogia é melhor mediatizada, não apenas pelas palavras, mas também pelos gestos, agora visíveis para todos.

Essas orientações metodológicas são ouvidas e postas em prática pela professora Verônica, o que explica o uso das duas salas: o laboratório de ciências para a experimentação e a sala de aula para a roda de conversa.

Passemos então análise da roda de conversa estabelecida entre a professora e seus alunos sobre a experimentação que acabaram de realizar. 


\subsection{Aula 02 - RODA DE CONVERSA: Como resolvemos o problema do barquinho e por que conseguimos resolvê-lo?}

Lembramos que os alunos que participam dessa roda de conversa já são conhecidos, famosos por suas contínuas perguntas e intervenções na aula "para cima e para baixo com o submarino", como também a professora Verônica já nos é familiar.

A roda de conversa é realizada com o objetivo de estabelecer comunicação entre alunos e professora sobre as ações necessárias à resolução do problema, isto é, ao como se resolveu, e ao por que se conseguiu resolver. Professoras da escola e equipe da universidade privilegiam essa roda de conversa como uma das ações fundamentais na apropriação de significados pelos alunos.

Tal privilégio já foi constatado no episódio de formação referente à organização da classe citado no item anterior e podemos reiterá-lo mediante o conteúdo da enunciação da formadora I proferida em outro fórum ou encontro formativo ocorrido na escola no dia 11/03/2008, citado a seguir. Formadora I e professoras da escola dialogam sobre signos mediacionais orientadores da conversa que deve ser estabelecida entre professora e aluno em classe, ao finalizar a atividade experimental. Segundo a formadora I, a conversa é organizada e orientada por meio dos signos "como" e "por que". Em suas palavras:

É a parte da discussão da professora com a turma, e essa discussão tem duas, é dividida, (...) cada uma tem uma pergunta essencial. A primeira é o como, como é que vocês fizeram, ou explica como é que fez, ou, depende da imaginação da professora essa [pergunta] tem mil jeitos de perguntar. Como foi..., isto é, pede uma descrição. Por que isto? Certo. Porque a construção do conhecimento se dá a partir da tomada de consciência do que vocês fizeram. Se você não toma consciência do que você fez, você não constrói o conhecimento.

E a professora tem que saber fazer o como, ouvir. É dificílimo ouvir. Dá uma vontade de falar logo... ouvir, deixar cada um falar e eles vão falar quinhentas vezes a mesma coisa. Ouvir quem não falou a mesma coisa, ele falou um pouquinho mais, que ele explicou um pouquinho mais, até ouvir que todo mundo tá falando a mesma coisa mesmo, daí já chegou um limite da classe para fazer a nova pergunta que é uma pergunta de procura da justificativa, de procura da relação causal. (...) Uma relação entre as variáveis. (...). Quando fez a experiência ninguém falou, quando discutiu ninguém falou, e apareceu no por que; o porquê é justamente a construção, a necessidade, quando você vai explicar uma coisa você tem a necessidade de criar uma palavra. Que é a criação do conceito (...) (Form. I, Fórum formativo na escola, 11/03/2008). 
A professora Verônica ouviu as considerações enunciadas pela formadora I, destacadas por introduzir elementos teóricos e metodológicos importantes para a formação docente. Primeiro para o reconhecimento do teor social da inter-relação, da comunicação e compartilhamento de compreensões mediadas por dois signos qualitativamente diferentes - o como e o porquê, cada um com seu papel e objetivo definido. A pergunta "como você fez para resolver o problema" tem em si o objetivo de levar os alunos a falar o que fez e como fez para que tomem consciência sobre suas ações. O segundo signo "por que você fez" intenta levar os alunos a estabelecer relações causais para "criar a palavra" com significado, isto é, para construir o conceito.

O segundo aspecto a ressaltar em tais considerações é a orientação para o papel mediacional da professora diante da necessidade de abrir espaços na conversação para a voz dos alunos e a de ouvi-los até que o objetivo intrínseco à discussão do "como" seja esgotado, isto é, até que todos os alunos estejam falando a mesma coisa sobre suas ações. Essa constatação deve ser interpretada pela professora como o momento para introdução do segundo signo - o porquê.

O destaque para esse trecho formativo se deve também à conotação dada à análise da mediação discursiva docente por esta investigação, à necessidade de colocar em cena vozes que apresentam o potencial de influenciar a professora em suas escolhas de ações, signos e instrumentos intermediadores entre seu motivo/objetivo e a aprendizagem de seus alunos. $\mathrm{O}$ nosso desafio abrange a discussão sobre quais são essas influências e sobre a relação entre as supostas influências e o seu desenvolvimento profissional.

Voltamos, então, para o cenário da sala de aula: professora Verônica e cerca de 35 alunos estão sentados em círculo conversando sobre as ações realizadas para resolver o problema do barquinho. A enunciação passa de um para outro, ora com perguntas, ora com afirmações ou complementos, sob mediação da professora, que, atenta aos braços levantados, vai indicando a voz que deve ser ressoada naquele momento, com cuidado para não deixar de garantir o espaço de fala para todos. Neste instante, quem fala é a professora: vamos nos atentar para o conteúdo expresso em sua mediação discursiva?

\section{Episódio de ensino I - como o problema foi resolvido e por que deu certo}

(17min: 50seg) 33. P - E não afundou... Por que será que deu certo, né? Muito.... que eu percebi durante a experiência, foi como Thais falou: vocês tentaram primeiro aquele barco de papel e não deu certo e vocês falaram que fizeram o barco quadrado ou o barco 
redondo e o outro usou o termo balsa. Por que será que deu certo quando vocês fizeram isso, hein? Por que será? Calma! (Vários falam ao mesmo tempo).

34. Mateus - Porque a gente trabalhou junto.

35. P - Só porque vocês trabalharam juntos?

36. Felipe - Porque a gente pôs 05 papéis de uma vez só, pra fazer a balsa.

37. Vitor - Aí não dava pra afundar, que estava um monte.

38. P - Então, por que não afundou? Estava um monte de quê?

39. Vitor e outros alunos - De papel de alumínio.

40. $\mathbf{P}$ - O que mais? Fala Wallace

41. Wallace - E porque a gente estava colocando um monte de alumínio, punha um monte de arruelas, e ia distribuindo o peso.

42. P - Então distribuíram o peso? Fala Kethelin

43. Kethelin - O nosso foi diferente. A gente colocou dois papéis e aí não deu certo, e quando a gente colocou cinco, foi demais, aí não deu, o barco afundou.

44. P - Olha que interessante isso, cinco papéis, o outro fez com dois, então, será que está só na quantidade de papel?

45. Alunos - Não (em coro)

46. $\mathbf{P}$ - O que será?

47. Felipe e outros alunos - Está distribuindo o peso. (19min: 08seg)

Em sua mediação discursiva no turno 33, a professora enuncia a pergunta que privilegia a discussão sobre as relações que justificam o sucesso na resolução do problema, isto é, a relação entre as variáveis consideradas importantes na flutuação do barquinho. Pelo conteúdo de sua mediação, ela já se sente satisfeita com a retrospectiva feita pelos alunos sobre o quê e como fizeram para resolver o problema, decidindo pela introdução da pergunta: “por que será que deu certo, né?” Essa pergunta instrutiva indica seu caráter objetal mediante o signo "por que", desencadeador da sequência de enunciações dos alunos de conteúdo previsto e desejado pela professora.

O signo "por que" não está sozinho, mas integrado à necessidade de fazer os alunos se lembrarem de suas próprias enunciações proferidas em turnos anteriores - da variável forma do barco, importante na explicação de como resolveram o problema, ou seja, os tipos de barcos feitos. Ao retomar os resultados da discussão anterior, mediada pelo signo "como", ela cria um contexto mental para introduzir a questão principal, aquela que encerra a base conceitual da compreensão a ser compartilhada - as relações causais que justificam o flutuar do barquinho, mesmo carregando muitas arruelas. 
Esse contexto mental não é senão uma síntese do que já é conhecido e compreendido, importante não apenas como um ponto de chegada, mas também como um ponto de partida para novas compreensões. Como explicita Edwards e Mercer (1988), um contexto mental seria exatamente o conjunto de compreensões compartilhadas por participantes de uma conversação, que os ajudam a dar sentido ao que dizem. Portanto, para a professora Verônica, as compreensões sobre formas e tipos de barcos tornam-se um contexto mental que lhe permite sintetizar o que já se sabe a respeito e iniciar a mediação da próxima discussão.

Na verdade, o contexto mental criado não é uma síntese apenas para as crianças, mas também para a professora: ao reunir as compreensões compartilhadas, ela organiza os seus pensamentos, se situa no contexto e o usa para se preparar para a retomada do processo de mediação. Afinal, o que se manifesta como conhecido e compreendido pelos alunos também o é para ela, além de lhe assegurar que o seu objetivo de levar os alunos a expressar e a tomar consciência de suas ações na resolução do problema de aprendizagem foi realizado. Eis mais uma referência à ação reversível da mediação discursiva sobre a mente docente.

A discussão tem continuidade sob mediação do signo "por que" interposto pela professora entre o seu motivo/objetivo de levar os alunos a estabelecer relações causais para que possam explicar sobre a flutuação do barquinho construído e o processo de apropriação dos significados condizentes com a base conceitual em pauta. Para realizá-lo, ela vai mediando com sua atenção centrada para ouvir as enunciações dos alunos, identificar as variáveis relacionadas à resolução do problema de aprendizagem, por conseguinte, correlacionadas à solução de seu problema de ensino, melhor dito, condizente com a sua necessidade de ensinar e de proporcionar a aprendizagem.

Orientada metodologicamente pela voz virtual da formadora I e pela sua experiência em mediar conversações com crianças, a professora busca dirigir a atenção e o motivo dos alunos para a satisfação de sua necessidade e realização de seu motivo. Para tanto, referenciase em variáveis que podem explicar a flutuação de corpos para problematizar, reafirmar e rejeitar as enunciações que vão sendo proferidas pelos alunos.

No turno 35, ela repete a enunciação de Mateus, para afirmar que trabalhar em grupo, embora importante, não era condição suficiente para resolver o problema, o que é expresso pela "só" (Só porque vocês trabalharam juntos?) e para mostrar-se aberta a outras respostas; a variável quantidade de papel introduzida por Felipe no turno 36 também foi recebida e avaliada pela professora como insuficiente em sua mediação discursiva do turno 
38, ao repetir sua pergunta inicial ("Então, por que não afundou? (...)") e ao solicitar mais informações.

No turno 41, Wallace, embora reforce a quantidade de folhas de papel como importante na resolução do problema, introduz a variável distribuição do peso, avaliada positivamente pela professora mediante a sua pergunta afirmativa no turno 42: "Então, distribuíram o peso?".

No turno 43, Kethelin enuncia o esperado pela professora, necessário para enfraquecer a variável quantidade de papel, não considerada por ela como imprescindível na flutuação do barco: “(...) quando a gente colocou cinco [papéis], foi demais, aí não deu, o barco afundou". Para Kethelin, o uso de muitos papéis pode ter provocado o afundamento do barco, conclusão bem aceita pela professora, em sua enunciação do turno 44: "Olha que interessante (...) será que está só na quantidade de papel?’. Mais uma vez ela utiliza a palavra "só" para expressar o seu desejo de ampliar a compreensão em compartilhamento.

Se não é só a quantidade de papel, qual variável também é necessária para explicar por que o barco não afundou? $\mathrm{Na}$ verdade, esta é a conotação da pergunta da professora no turno 46, ao enunciar "o que será?", cuja resposta "está distribuindo o peso", respondida em coro por um grupo de alunos.

A variável distribuição do peso ocupa posição de destaque no conteúdo da mediação discursiva da professora. $\mathrm{Na}$ verdade, parece ser o significado mais relevante na conversa, presente na memória da professora como palavra chave na composição da argumentação necessária à realização de seu objetivo.

As vozes presentes na memória da professora e verbalizadas no curso desta aula advêm dos fóruns formativos ocorridos no âmbito da parceria colaborativa com a universidade. Além do encontro que mencionamos anteriormente, ocorrido no dia 11/03/2008, citaremos mais dois, ocorridos no dia 13 de maio de 2008 e no dia 27 de maio do mesmo ano, ambos direcionados para a preparação das professoras na realização da atividade do barquinho, cujos focos de discussão foram a orientação metodológica de como ensinar ciências e a base conceitual contida no problema de aprendizagem.

No fórum ocorrido no dia 13/05/2008, a formadora I instrui as professoras para a discussão pós-resolução do problema, com foco nas relações causais explicativas da flutuação do barquinho. A formadora enuncia a mesma pergunta proferida pela professora Verônica junto aos seus alunos. É o que nos mostra o episódio de formação citado a seguir. 


\section{Episódio de formação - Por que o barco não afundou?}

143. Form. I - (...) se eu perguntasse: porque vocês fizeram esse barco? Por que é que deu certo?

144. Clara - Parece que é o equilíbrio mesmo, que ele era também grande pra distribuir a quantidade de peso.

145. Form. I - O equilíbrio e a distribuição.

146. Clara - E a distribuição!

147. Form. I - Então, nesta atividade, nós vamos parar aqui: equilíbrio e distribuição!

Então o professor de Ciências tá lá com uma cara, e a densidade, você não vai falar nada? Não! Nós não vamos falar nada.

148. Denis - Fazer uma questão que é bem simples... pensei em falar na quantidade da água que vai ser deslocada pelo barco... pela altura...

149. Form. I - Não, isso nós não vamos falar. Por quê? Por que são muito novos... mas vamos falar de equilíbrio e distribuição.

No fórum ocorrido no dia 27/05/2008, a form. II recomenda a mesma abordagem conceitual.

\section{Episódio de formação: Variáveis explicativas: distribuição, forma e tamanho do barco}

16. Form. II - Porque na atividade do submarino tinha essa questão dos nomes que poderiam complicar um pouco, agora o barquinho, eu acho que o ponto central que certamente os alunos vão pegar é a questão do tamanho do barco. Não me lembro de quando vocês fizeram. Eu não estava aqui quando vocês fizeram com a Form. I, mas o tamanho do barco influenciando na quantidade de peças que você pode carregar e, além disso, a distribuição dessas peças, os alunos vão falar muito disso, de que é necessário distribuir por toda área do barco feito, porque se não ele afunda também. (...) Então esses são os dois pontos principais que precisam aparecer na discussão, os alunos certamente vão falar disso, mas se não falarem, vocês deem um jeito de fazer perguntas que levem eles a colocar isso.

17. Mara - Em relação à distribuição e ao tamanho?

18. Form. II - A distribuição, forma e tamanho do barco.

19. Mara - Não complica, eu entendo, mas eles ...

20. Form. II - Eles não vão falar em distribuição e forma, mas vão dizer que precisava distribuir direitinho, precisava equilibrar, eles vão falar em equilíbrio. Equilíbrio é uma palavra que vem a tona com essa atividade, porque eles percebem que se coloca em uma ponta do barco uma pecinha, é necessário colocar na outra ponta a pecinha igual.

21. Coord. É a relação volume e massa ...

22. Form. II - É, volume, eles não vão falar, eles vão falar tamanho do barco e as pecinhas que distribuíram e a necessidade de lidar com o equilíbrio para o barquinho não 
afundar, é isso que vai aparecer. E pra gente é mais que suficiente, que é essa relação que faz com que o barquinho se mantenha na água.

No episódio de ensino a seguir, o conteúdo das mediações discursivas docentes manifesta, com mais transparência, a presença das vozes das formadoras na conversação estabelecida entre professora e alunos.

\section{Episódio de ensino II - As relações causais são compostas pelo aceite e descarte de variáveis}

(19min: 09seg) 48. P - Por que será que não afunda o barco?

49. Alunos - Porque a gente está distribuindo o peso.

50. $\mathbf{P}$ - Está distribuindo o peso, o que mais?

51. Sérgio - Distribuindo igualmente, pra não ficar só de um lado.

52. $\mathbf{P}$ - Isso ...

53. Thais - E também, o tanto de papel que nós colocamos, ajudou a boiar.

54. $\mathbf{P}$ - Então, o tanto de papel que vocês colocaram ... e aí elas falaram que colocaram menos papel que vocês, então, o tanto de papel é o principal? Aí vocês falaram que é distribuir o peso. Isso é o principal? Que mais?

55. Thais - Professora, [a gente] tinha quatro arruelas pequenas e a gente colocou assim na ponta do quadrado e aí, os outros nós colocamos no meio.

56. $\mathbf{P}$ - E aí não teve problema?

57. Thais - Não. A gente colocou dois papéis.

58. P - Tá ótimo. Então, distribuir o peso foi importante?

59. Alunos - Foi. (em coro)

60. Yuri - Mas também teve que levantar mais os lados do barquinho, porque senão a água entrava e ele afundava.

61. P - Isso! Então olha: ter uma proteção do lado do barco também foi importante. E aí, alguma coisa que nós descobrimos? A quantidade de papel era isso que mandava o barco afundar ou não? Era distribuir o [pausa] peso, como vocês disseram, isso que o colega falou, né? Fala Kethelin...

62. Kethelin - Quando a gente colocou um afundou e quando a gente colocou dois, não afundou.

63. P - E agora vou fazer uma pergunta: esse barco, redondo ou quadrado que vocês fizeram, ele ficou maior ou menor que o primeiro barquinho de papel?

64. Alunos - Maior. (em coro)

65. P - Isso será que tem a ver, ou não? O tamanho do barco?

66. Yuri - E aí a gente pode distribuir mais peso pra cada lugar.

67. $\mathbf{P}$ - Fala Yuri. 
68. Yuri - Pode distribuir mais peso para cada lugar.

69. P - Muito bem, olha o que a gente pode aprender com esta atividade, né? O tamanho da embarcação faz diferença? Além do tamanho da embarcação.

70. Camila -E o peso.

71. $\mathbf{P}$ - Fazer o que com o peso?

72. Alunos - Distribuir o peso.

73. $\mathbf{P}$ - Muito bem.

77. $\mathbf{P}$ - Ótimo, gente. Gostaram da atividade? Alguém que falar mais alguma coisa, fazer mais algum comentário? Por hoje é só?

78. Alunos - só.

79. P - Vamos fazer um relatório escrito! Vai escrever o que fez, como fez, porque fez, porque deu certo e depois vai ilustrar esse relatório do que você aprendeu. ... Essa vai ser sozinho porque eu quero ver o que cada um aprendeu, certo? (21min: 54seg)

O curso desse episódio segue no mesmo ritmo do anterior, cujas mediações contemplam o mesmo objetivo - o de estabelecer relações causais que expliquem a flutuação do barquinho de alumínio na água. A professora reforça sua pergunta no turno 48 - "Por que será que não afunda o barco?”. De mediação em mediação, a compreensão desejada vai sendo objetivada no conjunto de enunciações: a professora aceita a variável "está distribuindo o peso" e solicita complementos, o que significa dizer que apenas distribuir o peso no barco, embora "principal", não é suficiente para explicar a relação causal; tenta, mais uma vez, enfraquecer e descartar a variável quantidade de papel; aceita e reforça a variável referente à borda do barco ou à "proteção do barco", importante, para o aluno, apenas por não deixar a água entrar; introduz as variáveis tamanho e forma do barco no turno 63, ao propor que os alunos comparem o barco quadrado ou redondo com o tamanho do barquinho de dobradura, desencadeando uma sequência de falas tal qual ela pretendia e necessitava para se sentir satisfeita com aula.

Ambas as formadoras se fazem virtualmente presentes no conteúdo das mediações docentes. Os signos introduzidos por elas nos encontros formativos foram trazidos pela professora para compor suas ações mediadas estabelecidas entre ela e seus alunos no decurso da conversação em análise. Aliás, a professora mostra o seu compromisso com a orientação das formadoras, em especial da formadora II, a ponto de conseguir que os alunos estabelecessem as relações previstas. Para confirmarmos tal constatação basta compararmos o conteúdo das orientações da formadora II com o que dizem os alunos da professora Verônica. As três variáveis destacadas como mais importantes - a distribuição das peças no barco, 
tamanho e forma compuseram com mais ou menos ênfase, as mediações discursivas da professora e as enunciações dos alunos.

A formadora II alertou as professoras para o caso dos alunos não falarem sobre alguma dessas variáveis, ao sugerir que elas dessem um "jeito” de introduzi-la, “(...) um jeito de fazer perguntas que levem eles a colocar isso". Esse jeito sugerido aparece na mediação discursiva da professora Verônica no turno 63, ao introduzir, por meio de uma pergunta, a variável tamanho do barco, relacionando-a às formas redondo e quadrado.

De fato, a previsão da formadora II quanto a não menção da variável volume pelas crianças se confirma. Elas abordam as variáveis, mas sem relacionar uma com a outra. Nem ao falar sobre a borda do barco, se faz menção à ocupação do espaço dentro do barco, por exemplo. As variáveis abordadas pelos alunos e pela professora foram direcionadas para a necessidade de distribuir o peso. Essa linguagem aparece nos gestos e nas palavras das crianças, como vimos nos turnos 66 e 68 do segundo episódio de ensino: por meio de gestos e palavras Yuri diz que o tamanho do barco é importante porque "pode distribuir peso para cada lugar".

Na verdade, essa enunciação do Yuri não é explorada pela professora, como também não o é aquela enunciada no turno 60, em que ele se refere à necessidade da borda do barco. Yuri abre espaços na conversação não apenas para a introdução da variável volume, mas para expandir um pouco mais a compreensão sobre por que os objetos flutuam. Afinal, a enunciação do Yuri “distribuir peso para cada lugar", contém a essência da relação causal que fundamenta a importância do "peso total do barco" como uma variável fundamental para explicar a flutuação (Abib, 2013, p. 105). Aqui fica a dúvida sobre por que a professora deixa de lado essas oportunidades de tornar a conversação mais dialógica, talvez por concordar com as orientações das formadoras, ou por não se sentir segura quanto à base conceitual em questão, o que pode ter lhe impedido de ir além das orientações formativas. Afinal, é inegável o quão complexa é a base conceitual em questão, sobretudo nas escolhas do quê e do como abordá-la com crianças.

Provavelmente, a professora Verônica ainda não se apropriou teoricamente dessa base conceitual, pois como verificamos em suas enunciações, a sua percepção situa-se no campo do pensamento empírico, ainda presa às abstrações dos aspectos externos do objeto de estudo; para que o seu nível de abstração se situasse no campo do pensamento teórico, as suas enunciações deveriam explicitar com convicção as inter-relações explicativas da base sistêmica do conceito. Como escreve Dias \& Manzoni (2011, p.03) “Quando o conhecimento 
de uma transformação responde o porquê ocorre, no que resulta, sobre que base e devido a que possibilidade se converte no que é e não em outra coisa, tem-se o pensamento teórico, constituinte do conceito (teórico)".

Embora façamos essas considerações acerca do nível de apropriação e domínio da professora sobre a base conceitual em pauta, supomos que suas mediações discursivas não poderiam ter avançado muito para além do que presenciamos, a considerar, em primeira instância, sua formação específica como Pedagoga e Licenciada em Letras, com ênfase para a alfabetização na língua materna. Ela é um aprendiz no que diz respeito aos conteúdos de física introduzidos pelas formadoras.

Em segunda instância, podemos dizer que a formação contínua em serviço em processo na escola não resolveu essa lacuna deixada pela formação inicial. Basta direcionarmos nossa atenção mais uma vez para o conteúdo dos episódios de formação citados acima, para concluirmos que a formação realizada com o fim explícito de formar as professoras para realizar a atividade relativa à flutuação do barquinho não garantiu a expansão de seus pensamentos, de modo a possibilitar-lhes discutir as inter-relações causais de modo mais aprofundado. A base conceitual que encerra a flutuação de corpos não é abordada pelas formadoras em uma visão sistêmica, isto é, na totalidade dos nexos que embasam tal núcleo conceitual. Suas orientações são limitadas à suficiência da relação equilíbrio, distribuição e tamanho, tal como foi sugerido abordar com crianças.

De modo geral, as mediações discursivas da professora no curso desta aula não ocorreram com a mesma fluência da aula anterior, seja por insegurança em relação ao conteúdo, ou por limite de tempo, ou porque esse conteúdo continua em aulas seguintes, ou ainda, por algum outro fator de natureza desconhecida. Nos últimos turnos de falas da aula, por exemplo, ela retoma as variáveis mencionadas com brevidade, sem insistir muito na participação das crianças na composição da compreensão coletiva. O objetivo manifesto é o de reafirmar essas variáveis como as mais importantes na explicação das causas da flutuação do barquinho de alumínio ao transportar muitas arruelas.

As figuras apresentadas, a seguir, nos possibilitam uma visualização geral das mediações discursivas e do padrão temático da presente aula. A partir dessa visão geral, retomamos a discussão sobre quais relações podemos estabelecer entre o processo de mediar da professora e o seu desenvolvimento profissional. 
Figura 11 - Mediações discursivas e objetivos docente na roda de conversa "o barquinho".

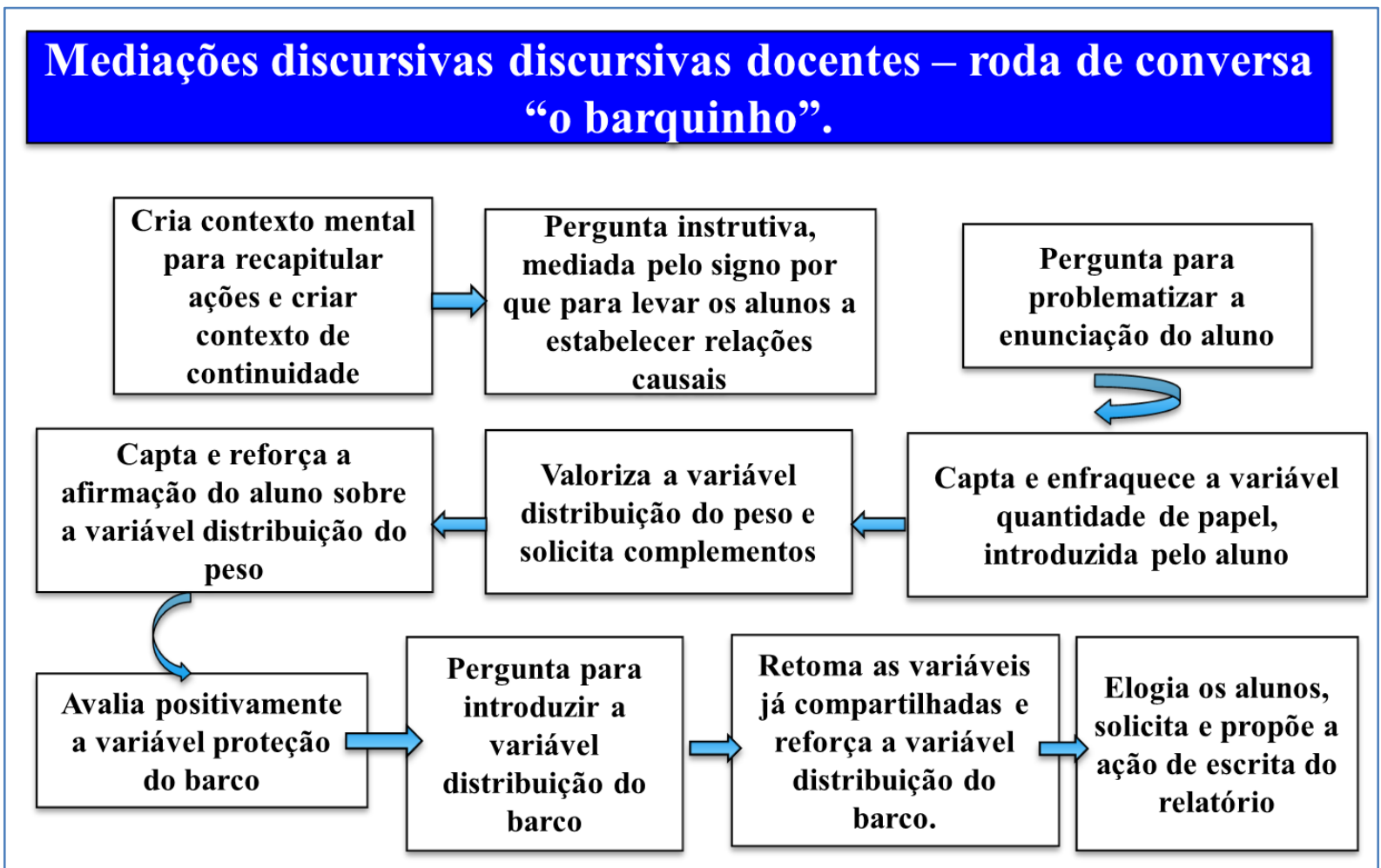

Figura 12 - Padrão temático roda de conversa "o barquinho"

\section{PADRÃO TEMÁTICO: o barquinho não afundou, porque...}

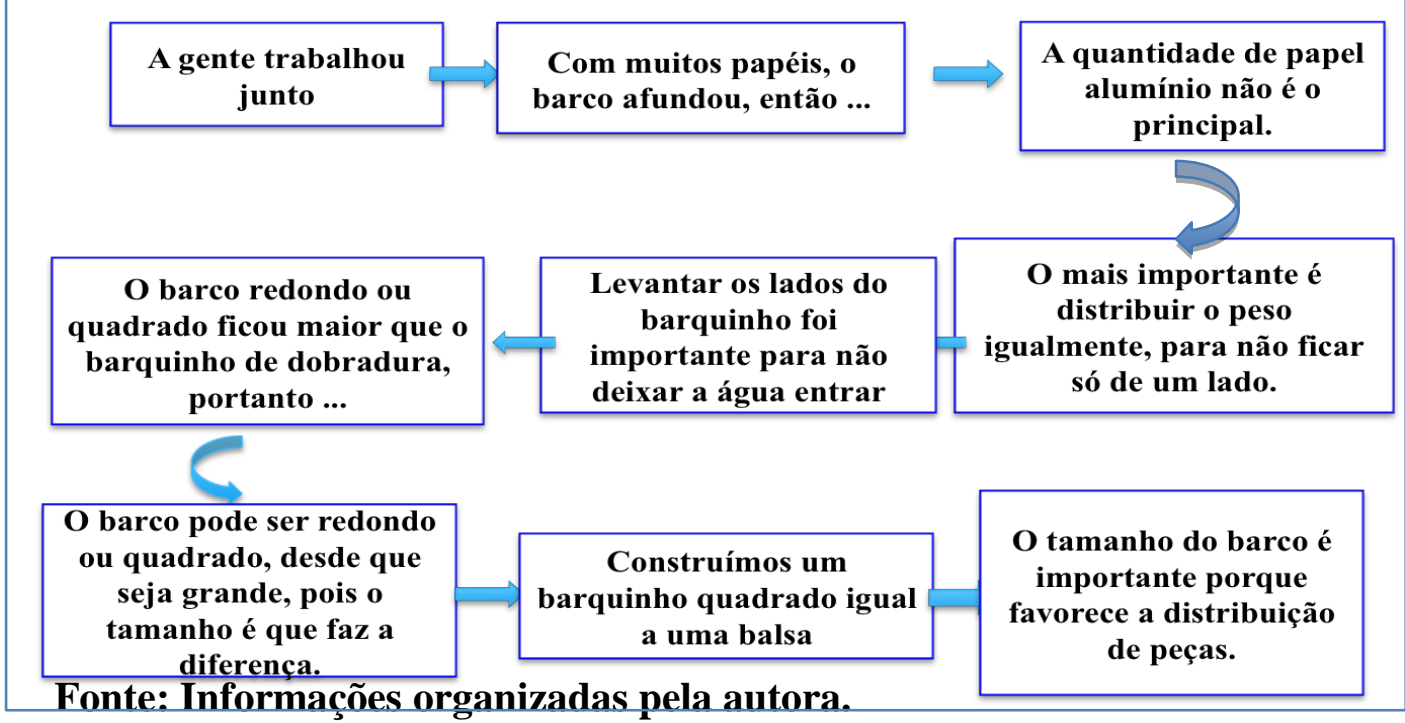

Enfim, quais relações podem ser estabelecidas entre o conjunto de mediações discursivas e o desenvolvimento profissional docente? 
Há dois aspectos a destacar sobre essa complexa relação. Primeiro ressaltamos o potencial de reversibilidade das mediações sobre a mente da professora, a considerar os objetivos de levar os alunos a tomar consciência sobre ações realizadas e a estabelecer relações causais. $\mathrm{O}$ movimento mental proposto aos alunos foi efetivamente realizado pela professora passo a passo, com acréscimos de outros movimentos pertinentes ao seu papel de mediadora: dirigir a atenção do aluno para determinado foco, requer atenção centrada; reforçar ou rejeitar variáveis requer prévia avaliação; suscitar novas variáveis e introduzir aquelas não abordadas exige que se tenha visão sobre a totalidade da compreensão a ser compartilhada; recapitular ações e ou significados compartilhados requer organização de seus próprios pensamentos, de modo a ter em memória a síntese desejada; para elogiar a atuação dos alunos, é preciso comparar essa atuação com os resultados esperados, isto é, com os objetivos previamente planejados. Enfim, temos aqui representado, a um só tempo, o processo de mediação docente com o fim explicito de transformar qualitativamente o nível de apropriação dos alunos e o suposto processo de autotransformação da professora em seu processo de trabalho. Aqui vale o lembrete de que estamos tratando da tese marxista que orienta esta investigação, a de que ao transformar o seu objeto de trabalho, o sujeito se autotransforma; além da máxima de que o trabalho, desenvolvido como atividade, pode promover o desenvolvimento profissional.

Outro aspecto é a suposição de que a professora realizou seus motivos/objetivos, com o compartilhamento de conhecimentos ou compreensões relacionadas às variáveis imprescindíveis à flutuação do barquinho, tal como foi previsto pelas formadoras. O elogio dirigido pela professora às crianças nos turnos 73 e 77, ao enunciar "Muito bom" e "Ótimo, gente!”, respectivamente, manifesta a sua sensação de realização, de objetivo atingido, importante para reforçar seu motivo, por conseguinte, imprescindível para a construção de seus sentidos ou para reiterar aqueles já construídos e que são correspondentes com a significação social da docência, como tal, favoráveis ao seu desenvolvimento profissional.

Entretanto, essa discussão sobre o potencial de reversibilidade dos modos de mediação adotados e sobre a realização dos motivos/objetivos merece ponderações, por levarmos em consideração o nível de apropriação e domínio da professora sobre os signos interpostos, como já mencionamos, e o possível limite teórico inerente às compreensões compartilhadas.

Caso a nossa intenção fosse tomar as orientações proferidas pelas formadoras como parâmetro para avaliar a realização dos motivos e objetivos docentes, diríamos que a professora Verônica cumpriu a expectativa esperada por elas. De fato, a professora se 
estabeleceu nos limites das orientações formativas e dos conteúdos apresentados e discutidos nos encontros circunscritos à parceria da escola com a universidade. Motivos/objetivos foram realizados no âmbito desses limites, refletidos nos nexos estabelecidos por seus alunos, ao explicarem por que o barquinho não afundou.

Com base no sentido atribuído por Vigotski (2009a) ao processo criativo humano, caracterizado por ele como de reprodução e/ou de combinação, dizemos que a professora, no exercício desta aula especificamente, imprime à sua atividade criativa o caráter de reprodução, sem combinar às suas ações novos signos teóricos para além daqueles que lhe foram ensinados. A professora combina às suas mediações discursivas elementos característicos de sua personalidade laboral, constatadas nos modos de mediação, próprios ou em processo de apropriação e domínio característicos de seu modo geral de ação. Como exemplos, poderíamos citar: a partilha das vozes e do poder; as perguntas, que persistem com fins variados; avaliação, valorização e ênfase sobre as enunciações dos alunos com vistas às compreensões compartilhadas. Portanto, a criação objetivada no final da aula incorpora não apenas os signos teóricos interpostos, mas os signos e instrumentos adotados pela professora para mediar a conversação.

Todavia, essa ponderação gera outra de igual importância. O suposto caráter de reprodução localizado na atividade criativa da professora mostra pelo menos duas contradições. A primeira está circunscrita aos objetivos que regem os dois processos formativos que acontecem no âmbito da organização do ensino de ciências nos anos iniciais, o próprio da escola e o outro instituído por meio da parceria com a universidade. Enquanto um persegue a construção da autonomia docente mediante a busca por apropriação e domínio docente de seus instrumentos de trabalho, o outro, com atuação temporária na escola, tem a intenção de testar sequências didáticas elaboradas por seus pesquisadores para avaliarem se os resultados são condizentes com as expectativas de aprendizagem de alunos dos anos iniciais. (Azevedo, 2008; Azevedo, Fonte e Navarro, 2010).

A segunda contradição reside na relação estabelecida entre a atividade criativa reprodutiva da professora e o seu desenvolvimento profissional. Como a professora, participante ativa de ambos os processos formativos, parece lidar com tais contradições? Que lugar a suposta atividade reprodutiva ocupa em seu desenvolvimento profissional?

Podemos seguir dois caminhos interpretativos. Com base em Wertsch (1999) poderíamos supor que a professora, inserida em uma situação de conflito ou resistência, estaria simulando o uso dos signos advindos das orientações formativas. A simulação seria explicada pelo seu domínio sem apropriação sobre esses signos, os quais, embora 
compusessem o plano de sua consciência, não seriam tomados como seus e como tal, logo seriam abandonados e não integrados às suas ações em aulas futuras. Nesse caso, nenhum grau de avanço seria contabilizado em seu desenvolvimento. E nem de recuo, a supor o seu grau de consciência no processo de simulação dos ditos modos de mediação.

Outra interpretação é a de que os motivos das formadoras teriam potencializado o motivo da professora. De um lado, a professora se move para garantir a aprendizagem de seus alunos, e, de outro as formadoras são impelidas pela necessidade de aplicar as sequências didáticas a fim de verificar sua qualidade diante da aprendizagem dos alunos. A professora, na condição de um sujeito em atividade, por conseguinte, com controle sobre seu processo de trabalho, poderia ter visto nas proposições teóricas e metodológicas enunciadas pelas formadoras boas possibilidades de garantir o desenvolvimento intelectual de seus alunos, o que não comprometeria a relação de correspondência que há entre o seu motivo e o objetivo de sua docência. A consequência disso seria a incorporação da ação de aplicar as orientações formativas ao seu conjunto de ações, as quais compõem sua atividade pedagógica. Essa incorporação elevaria a ação de aplicar, ainda que em caráter de reprodução, ao status de uma ação, assim como as demais, com objetivo correlacionado ao objetivo que orienta sua atividade. Essa interpretação, contrária a outra, nos conduziria a conclusões favoráveis à ideia de que as vozes das formadoras, comparecidas virtualmente nas mediações docentes colaboram com a professora na resolução de seu problema de ensino, por conseguinte, na realização de seus motivos/objetivos.

Optamos pela segunda opção. Primeiro porque não ignoramos o que já sabemos sobre a personalidade laboral da professora até este ponto da análise, e nem desmerecemos os sentidos atribuídos por ela à sua atividade pedagógica, constatados também na narrativa sobre sua experiência formativa e profissional. Cada situação pode ser vivenciada, interpretada e ressignificada por ela a partir de motivos e sentidos construídos ao longo de sua vida.

Lembramos a tempo que a aula analisada anteriormente também pertence às sequências didáticas elaboradas pela equipe parceira da escola e, no entanto, não foi desenvolvida pela professora em caráter de reprodução. Como mencionamos, embora o texto base adotado pela professora junto com seus alunos pertença aos conteúdos das sequências, as mediações discursivas contemplam conteúdos correspondentes ao nível de apropriação da professora, formado com seus próprios estudos, sem influências das citadas orientações formativas. 
Em segundo lugar, porque não nos esquecemos de que estamos tratando de um sistema coletivo de atividade, cujo desenvolvimento e mudanças são promovidos por contradições, as quais, ainda que gerem perturbações e conflitos e porque geram, introduzem elementos que podem renovar a atividade dos sujeitos envolvidos (Engestrom, 1999; Daniels, 2003). Todavia, afirmar o potencial de renovação gerado por situações conflituosas significa também dizer o oposto, de que essas situações conflituosas podem não produzir elementos novos, isto é, podem não provocar mudanças.

Portanto, estamos convencidos de que o processo de desenvolvimento profissional da professora Verônica, afetado pelos conflitos gerados pelas aparentes contradições, segue adiante com possibilidades de avanços mais do que paralisações e/ou recuos. Em tal contexto, ousamos considerar a presente aula em análise como uma situação de aprendizagem da docência, ainda que não possamos mencionar ou indicar a qualidade dessa aprendizagem. $\mathrm{O}$ seu caráter de aprendizagem é conferido pela sua constituição como uma situação colaborativa, garantida pela multivocalidade do sistema coletivo de atividade, do qual faz parte. O movimento dialógico discursivo em tal aula conta com mais vozes que as de costume: além das vozes das crianças, ouvimos as vozes da professora, as quais verbalizam tantas outras contidas em sua memória, entre elas, as orientações das formadoras, que, no momento da conversação, cumprem o papel de parceiras mais experientes. Afinal, como nos alerta Vygotsky (1987), o parceiro mais experiente pode comparecer virtualmente na conversa e pode colaborar com a resolução de algum problema ou como Daniels (2003, p. 95) prefere interpretar: o que poderia "parecer ser uma solução individual de problema pode ainda ser pensado como uma atividade colaborativa, visto que a 'voz' do 'outro' pode ainda servir para guiar ações individuais".

Portanto, as formadoras, virtualmente presentes, podem ter exercido o papel de parceiras mais experientes e colaborado com as mediações discursivas da professora. Entretanto, ainda que defendamos tais pressupostos, impossível se torna a mensuração e muito menos a demonstração de quantos passos a mediação da presente aula provocou em seu desenvolvimento profissional (Vigotski, 2009 b). Preferimos nos limitar à ideia de que a roda de conversa que acabamos de analisar faz parte de seu desenvolvimento com grandes chances de incidência sobre sua ZDP, seja pelas contradições manifestas, seja pelo caráter de reversibilidade das mediações discursivas, como também pela colaboração das vozes contidas em sua memória.

Por fim, avaliamos que a presente análise nos fez avançar passos promissores em 
direção ao nosso objeto de investigação, por nos possibilitar visualizar para além da aparência do movimento dialógico discursivo, nos mostrando as inter-relações entre ele e as comunidades vocais, especificamente entre as vozes presenciais da sala de aula com vozes trazidas pela memória docente de encontros formativos. Esse olhar mais apurado possibilitou situar o desenvolvimento profissional da professora para além dos seus esforços individuais, visto como fruto de relações que medeiam encontros humanos regidos por necessidades e contradições.

Passamos, então, à análise da próxima aula.

\section{Dois anos depois: contextualização para a análise da próxima aula}

Estamos em12 de novembro de 2010, 02 anos após a aula do barquinho. Nesse ano letivo, a professora Verônica está com uma classe de $2^{\circ}$ ano/série, com crianças na faixa etária entre 7 e 8 anos, em processo de alfabetização na língua materna, o que exige da professora a criação de oportunidades de aprendizagem que encerrem o objetivo de articular a apropriação de significados de cunho científico com a apropriação e domínio sobre o ler e o escrever.

A aula em análise, intitulada "o que aprendemos sobre os dinossauros e a pré-história humana", consiste em uma roda de conversa, uma das últimas ações circunscritas à Atividade de Aprendizagem denominada "Os dinossauros e a pré-história humana", planejada e estruturada pelo grupo de professoras com o apoio da coordenadora do laboratório de ciências.

Como esclarecemos no contexto da pesquisa, não obstante à existência do programa de conteúdos introduzido na escola pela parceria colaborativa estabelecida entre a escola e a universidade, o grupo de professoras continuou com a organização do ensino por meio da realização das Atividades Investigativas de Ensino, com foco sobre a resolução de problemas de ensino, mediante a elaboração, desenvolvimento e análise de Atividades Investigativas de Aprendizagem. Contudo, merece destaque o fato de que as rodas de conversa se estabeleceram com mais frequência e até como uma estratégia de conclusão e avaliação de aprendizagem a partir do trabalho com a parceria.

Ao decidirem pelo estudo dos dinossauros e da pré-história humana, as duas professoras responsáveis pelas classes de $2^{\circ}$ ano pretendiam criar oportunidades de aprendizagem para organizar e ampliar os conhecimentos das crianças a respeito dos dinossauros e levá-las ao desenvolvimento de noções gerais sobre os ancestrais humanos, suas 
características, modos de sobrevivência e modos de comunicação, além de levá-las à apropriação do conceito de fóssil.

As ações circunscritas a essa atividade variaram entre a construção de painéis, pesquisas, resolução de problemas via experimentações, escritas espontâneas, escritas coletivas, leituras de textos científicos, jogos de percurso, projeção de filmes, leituras de livros literários, rodas de conversa. Durou aproximadamente dois meses, finalizada com a exposição dos trabalhos na feira cultural da escola, com grande visitação dos familiares, atraídos, sobretudo pelo "Vale dos Dinossauros" e pelo "Sítio Arqueológico", ambientes construídos pelas crianças sob orientação de suas professoras. Para eventuais consultas, a descrição da atividade está em anexo.

\subsection{Aula 03: RODA DE CONVERSA - O que aprendemos sobre os dinossauros e a pré-história humana}

A riqueza no conteúdo da conversação foi o principal fator de escolha dessa aula para análise. Com duração de 15 minutos, a roda de conversa apresenta 197 enunciações de diferentes qualidades. Por meio de suas mediações discursivas, a professora busca mediar o processo de comunicação, de modo que esse se estabeleça mediatizado pelo conteúdo das enunciações. Parafraseamos Mortimer \& Scott (2002) para dizer que nessa aula de ciências há palavras por toda parte, tantas que até recorremos a Edwards \& Mercer (1988) para nos referirmos a essa aula como um contexto mental e linguístico, cujas falas contemplam conteúdos conhecidos e compreendidos pelos participantes. São os significados das palavras, isto é, os seus conteúdos que dão sentido ao que é dito para e por cada um dos sujeitos envolvidos (Edwards \& Mercer, 1988).

De início, antecipamos a percepção de que o assunto tratado na conversação parece fazer sentido tanto para a professora como para as crianças. Esse sentido, por sua vez, parece estar inter-relacionado ao motivo que os mobilizam. No caso das crianças, estudar os dinossauros não deixa de ser uma continuação de suas brincadeiras, pois elas demonstram fascínio por esses animais, os quais fazem parte de seus brinquedos sob variadas formas e tamanhos. Surpreendentemente, o envolvimento com o estudo do homem da caverna acompanha esse fascínio, provavelmente explicado pelo quão enigmático e fantasioso esse conteúdo deve ser aos olhos infantis. 
No caso da professora, seu motivo/sentido parece estar relacionado com o objetivo da roda de conversa, fazer com que as crianças falem e se comuniquem para que possa avaliar a sua aprendizagem.

\section{Abertura da aula}

Às 14 horas do dia 12 de novembro de 2010, a professora Verônica e sua classe com cerca de 30 crianças entram no laboratório de ciências, onde encontram cadeiras disponibilizadas em um grande círculo. As crianças agitadas disputam as cadeiras mais próximas da professora, que logo aumenta o tom de sua voz, emitindo sua voz "pública", como diz Lemke (1997), "sua voz de professor", culturalmente autorizada a essas incursões, para chamar a atenção e orientar a disposição de cada criança, separando algumas e trazendo outras para próximo de si. Em menos de 30 segundos, transparece uma calmaria há poucos instantes inimaginável. A professora, ainda em voz alta, reafirma os propósitos da aula, de modo a colocar as crianças em sintonia com o objetivo da atividade e, assim, criar condições para iniciar a conversação. Com as condições dadas, a conversa tem início:

\section{Episódio de ensino I - Quem gostaria de falar alguma coisa sobre o que aprendeu sobre os dinossauros?}

(00:57seg) 1. P - A gente sabe muita coisa sobre os dinossauros através do quê? Quem quer falar? (muitas crianças levantam as mãos)

2. Cs - Dos paleontólogos.

3. $\quad \mathbf{P}$ - O que são paleontólogos? (algumas crianças levantam os braços, prontas para falar, mas Artur é mais rápido que as demais).

4. Artur - Eles estudam os ossos, eles escavam os desertos também, eles exploram as áreas desconhecidas também e acham fósseis de dinossauros.

5. $\mathbf{P}$ - Isso, e aí através desses estudos a gente ficou sabendo um monte de coisas sobre eles, não foi? Sobre os dinossauros. Quem gostaria de falar alguma coisa sobre o que aprendeu sobre os dinossauros? Fala Lucas.

6. Lucas - Eu aprendi assim que na época dos dinossauros tinham uns pernilongos que ficavam picando os dinossauros e eles acabavam ficando dentro de uma pedra e enterrados.

7. $\mathbf{P}$ - (muito surpresa) - Mas você aprendeu isso nas aulas?

8. Lucas - Não, mas já vi num livro de dinossauro.

9. P - Fala Geovana. (1min: 57seg) 
O primeiro turno do episódio marca o início da conversação, em que a professora faz sua primeira pergunta para introduzir a discussão, vindo a mostrar na pergunta do turno 05 seu verdadeiro objetivo ou o motivo para o qual a sua ação se dirige - o de fazer com que as crianças exponham o que aprenderam ao longo do desenvolvimento da atividade de aprendizagem, na qual essa conversação se insere.

Notamos que as crianças não tiveram nenhuma dificuldade em responder as perguntas da professora, sobretudo a primeira, cuja resposta aparece em coro, subsidiando a seguinte, prontamente respondida pela criança no turno 04. Como perguntas instrutivas, as enunciações proferidas nos turnos 01 e 03 , contempladas no padrão triádico ( $-\mathrm{R}-\mathrm{E})$, geram respostas previamente desejadas e conhecidas pela professora (Lemke, 1997).

Entretanto, a pergunta do turno 05, ainda que sob o caráter de instrução, gerou uma resposta inesperada pela professora, cujo conteúdo a surpreendeu. Lucas afirma ter aprendido sobre pernilongos que picavam os dinossauros e ficavam enterrados na pedra. Como o aluno Lucas teve acesso a tais informações? Não foi em sua aula, confere a professora. Ao se criar contextos de aprendizagem, em que se privilegia a comunicação, sobretudo entre crianças, muitas surpresas podem acontecer. Ao se sentirem ouvidas e instigadas, elas tendem a manifestar o seu universo cultural e a expor seus conhecimentos advindos de fontes extraescolares, como de determinados programas de televisão, de pesquisas na internet, de conversas com familiares, entre outras. Segundo a professora, ela própria incentivava os alunos a pesquisar em diferentes fontes, a conversar com os pais, a assistir filmes sobre os dinossauros, além daqueles que foram projetados em suas aulas (EI, 2010).

No caso da informação trazida pelo aluno Lucas, a professora, surpresa e, possivelmente, sem colaboração de nenhuma voz advinda de sua memória, não levou a conversa adiante, contentando-se com a resposta do Lucas e, imediatamente, dando o poder de fala para a aluna Geovana. A informação enunciada pelo Lucas não foi compartilhada, talvez porque a professora não tenha conhecimento para avaliar a qualidade da informação ou talvez por não considerar o assunto relevante. A primeira hipótese parece ser a mais plausível, o que pode ter justificado a não problematização do conteúdo, tal como a professora geralmente prefere mediar.

De fato, a enunciação do Lucas gerou uma lacuna ou uma descontinuidade no fluxo discursivo dessa conversação. É o que nos diz uma breve anotação encontrada no diário da 
pesquisadora (2010, p. 27), a qual nos informa da existência de uma conversa entre a professora Verônica e suas parceiras de trabalho, sobre o assunto. Em tal conversa, Verônica comenta sobre uma pesquisa por ela realizada, por meio da qual ficou sabendo que havia na época dos dinossauros mosquitos que, após picarem os dinossauros e sugarem o seu sangue, pousavam em árvores, ficavam presos e fossilizados em âmbar, seiva derramada do tronco de determinadas espécies de árvores.

Possivelmente, o aluno Lucas se referia a esses fósseis, ainda que falasse em fóssil de pernilongo que ficava enterrado dentro de uma pedra. Talvez tenha se influenciado pela produção de fósseis em argila feita por ele e seus colegas dias antes, e/ou tenha assistido o filme de ficção Jurassic Park, no qual se faz referência ao método fictício de recriação dos dinossauros com base em DNA encontrado em mosquitos fossilizados em âmbar.

Do lado da professora, não é difícil presumir que a situação desencadeada pela enunciação do menino Lucas gerou necessidades formativas, resolvida por ela própria em sua iniciativa de pesquisar, de buscar em algum livro ou em outra fonte, a voz de alguém com mais conhecimento que se posicionasse naquele instante como o parceiro mais experiente. A solução de tais necessidades, manifestada na conversa entabulada com suas parcerias de trabalho, conclui o processo com características que o eleva ao status de uma situação de aprendizagem, como tal, potencialmente incidente sobre a sua Zona de Desenvolvimento Proximal.

Embora este episódio seja tão curto, nos permite fazer mais uma inferência quanto à proximidade da linguagem das crianças com a linguagem científica. A nosso ver, há elementos científicos nos diálogos, nas intervenções dos alunos Arthur e Lucas, nas quais notamos que o significado sobre fósseis começa a fazer sentido para eles. O aluno Artur, sobretudo, fala com propriedade sobre o que fazem os paleontólogos: “eles [os paleontólogos] estudam os ossos, eles escavam os desertos também, eles exploram as áreas desconhecidas também e acham fósseis de dinossauros".

Antecipamos que o conteúdo da conversa mostra a possibilidade de que a professora esteja introduzindo a linguagem científica em suas aulas de ciências, além de nos permitir discutir o potencial de suas mediações discursivas em sala de aula na realização de seus motivos com reversibilidade sobre sua própria aprendizagem.

Essa discussão tem continuidade com o curso da conversação. Se ampliássemos a imagem, veríamos cenas compostas por crianças de braços erguidos a espera de sua vez para 
falar; algumas delas, apoiam o braço levantado na cadeira, ou vai alternando os braços, mas não desistem da espera; muitas se sentam na ponta da cadeira; algumas mais ansiosas ficam de pé, ou atropelam a enunciação do colega. A professora vai apontando para a criança que deve falar naquele momento, falhando, às vezes, na ordem de pedidos de falas, em decorrência dos tantos braços erguidos ao mesmo tempo. É a professora, em seu papel de mediadora, que dá o tom e o ritmo da conversa, ao concluir um assunto e enunciar o início de outro.

\section{Episódio de ensino II - O homem da caverna}

(03min: 40seg) 45. P - (...) Então a gente viu que tinham os dinossauros, olhe só o que vocês falaram, que caiu um meteoro, que separaram os países, não é Leonardo? A Terra evoluiu, aí passada a época dos dinossauros, nós aprendemos o quê? O que que a gente estudou?

46. Vitor - O homem da caverna.

47. $\mathbf{P}$ - O que você aprendeu, fala Vitor?

48. Vitor - Que eles eram diferentes de nós.

49. $\mathbf{P}$ - Por que eles eram diferentes de nós? (muitas crianças levantam as mãos e sob mediação da professora, elas citam diferenças, como características do corpo, roupas, e falam de como eram as cavernas, que eram habitadas apenas no inverno, até que a professora retoma no turno 80).

80. $\mathbf{P}$ - Vocês estão falando das diferenças entre nós e o homem da caverna. Eles eram muito diferentes?

82. P - Por quê?

83. Leonardo - Eles mesmos faziam as roupas deles com pele de animal.

84. Bianca - Eles eram mais feios do que nós (todas as crianças dão risadas).

85. P - Por que você acha eles eram mais feios do que nós?

86. Bianca - Porque eles pareciam macaco. Vinha até aqui o nariz (demonstra com os dedos) (muitos risos).

87. $\mathbf{P}$ - Vocês concordam com isso?

88. Cs - Sim (em coro).

89. $\mathbf{P}$ - Eles eram muito diferentes, não é? A gente aprendeu que aconteceu o quê para eles ficarem diferentes?

90. Cs - Evoluíram (falam alto e juntos).

91. P - Eles evoluíram, foram se aperfeiçoando... né, foram melhorando...

92. Pedro - Antes as ferramentas eram diferentes. Agora têm muitos tipos de ferramentas, ferramentas de aço, de ferro.

93. C - Automática (não aparece a criança no filme, ouve-se apenas a sua voz). 
94. Isabele - Antes eles faziam com pedra.

95. $\mathbf{P}$ - O que eles faziam com pedra?

96 . Muitas crianças - ferramentas.

97 . P - As ferramentas, não é?

(...)

100. Artur - Professora, eles também acendiam fogo com duas pedras (esfrega uma mão na outra com se estivesse friccionando uma pedra na outra).

101. P - Então, olhem só. Como a Bianca disse que eles eram mais feios do que nós, não tinham essas armas (ferramentas) que o Pedro falou, mas eles eram inteligentes?

102. Cs (em coro) Eram.

(...)

107. Marcos - Oh prô, quando o homem da caverna foi evoluindo, foi ficando mais inteligente e foi inventando cada coisa para poder usar!

108. P - Isso... Fala Geovana.

109. Geovana - E os homens da caverna não são iguais aos outros, um tem cabelo maior, outro tem cabelo menor ...

110. Marcos - um tem sobrancelha grande e outro não.

(...)

112. $\mathbf{P}$ - isso. A gente viu que o Homem de Neandertal era diferente do Homo erectus, não vimos? (...) (10min: 44seg)

A mediação discursiva que mais se destaca neste episódio é o deslocamento mental entre contextos espacial e temporal, a qual possibilitou às crianças estabelecer relações entre 0 homem primitivo e o homem da sociedade atual. Logo no turno 45, o primeiro do episódio, a professora sintetiza o que já foi explicitado para, em seguida, formular a pergunta que desencadeia uma nova sequência de enunciações. A síntese feita pela professora garante à ela e às crianças uma viagem a um passado longínquo, acontecido há milhões de anos atrás, quando o Planeta Terra era habitado por dinossauros e ainda se constituía como uma Pangeia, ou seja, como um continente indiviso. Por meio das palavras da professora, as crianças se deslocam mentalmente até essa época dos dinossauros e de lá retornam à pré-história humana, isto é, aos primórdios da humanidade, quando não mais existiam dinossauros.

O conteúdo do discurso docente possibilita que a conversação, embora realizada em tempo presente, aborde lugares e uma cultura humana apenas alcançada via intercâmbio de conhecimentos, pensamentos e imaginação. A imagem do homem da caverna, bem como as informações contidas nos filmes assistidos e nos textos estudados em aulas anteriores, tornam-se signos mediadores do processo de comunicação e de intercâmbio cultural entre os 
participantes. A comunicação se faz possível, exatamente, pelo fato de se ter como pensamento generalizante noções conceituais do significado homem da caverna.

Outra informação mediadora da conversa, não aparente, mas implícita na memória dos participantes, é a de que humanos e dinossauros não viveram na mesma época. As crianças já sabem que os dinossauros foram extintos muito antes da aparição da espécie humana no planeta Terra. Entretanto, o compartilhamento dessa informação não foi algo corriqueiro na classe da professora Verônica. Como já foi narrado na história da vida profissional e formativa da professora, esse assunto foi escolhido para dar inicio à atividade de aprendizagem e pautado na primeira aula. Os alunos deveriam conversar com seus familiares sobre a existência ou não de seres humanos na época dos dinossauros e trazer resultados da conversa para aula a seguinte. Como já mencionamos antes, uma das respostas da classe foi uma bíblia para crianças trazida por um dos alunos, cujo conteúdo expunha a ideia de que os dinossauros também entraram na arca de Noé. Após conversarem via telefone, professora e coordenadora decidiram que o livro seria lido em partes, com o devido respeito às duas linguagens - a da respectiva religião e a científica. Para a professora esse episódio foi "muito interessante, levei o livro para casa, li, selecionei alguns trechos (...), li pra eles e deixei bem claro que era a visão religiosa, e que na escola, nós não íamos discutir apenas a visão religiosa, nós íamos discutir a visão científica” (EI, 2010).

Mediante esse relato, além de explicitar a origem do signo implícito na conversa (homens e dinossauros não viveram na mesma época), demos destaque para um modo de aprendizagem da docência coerente com o desenvolvimento de atividades conjuntas entre professores. O fato de se sentir apoiada e de poder solicitar ajuda diante de necessidades, foi significativo para essa professora e, certamente, o seria para qualquer outra. A segurança da presença física ou virtual do parceiro mais experiente incita a voos mais altos, para além dos conteúdos e modos de ensinar em processo de apropriação e domínio pela professora. Essa assertiva está presente na aula em análise: os significados condizentes ao objetivo de ensino da professora não são necessariamente totalmente apropriados por ela, mediados sob apoio e colaboração de suas parceiras de trabalho, em especial da coordenadora. Como a própria professora diz: “(...) eu nunca planejei uma aula sozinha, e eu contava com a coordenadora. (...) Mas era legal, porque eu estava sempre em contato com ela” (EI, 2010).

A informação sobre a não convivência temporal e espacial entre dinossauros e espécie humana, bem como as noções conceituais sobre o homem da caverna se constituem, para professora e crianças, como um conjunto de signos mediadores da conversação e 
mediatizadores da comunicação entre esses sujeitos. Esses signos, combinados à imaginação e criação, possibilitam o deslocamento mental, espacial e temporal dos sujeitos envolvidos. Aliás, não há outra maneira de estudarmos momentos da história humana, não vividos por nós, como a pré-história humana, por exemplo, se não for pela atividade criadora. Como afirma Vigotski (2009 a, p.12), nós não conseguimos reproduzir impressões nunca antes sentidas, mas apenas criá-las ou imaginá-las. A formação de uma imagem ou de um quadro sobre o homem primitivo em nossas mentes não acontece pela simples "restauração de excitações nervosas que chegaram ao cérebro", pois nunca vimos, de fato, esse passado e esses ancestrais de nossa espécie. Para que professora e crianças pudessem conversar sobre esse passado tão remoto da filogênese da espécie humana, os seus cérebros combinaram e reelaboraram, "de forma criadora, elementos da experiência anterior, erigindo novas situações e novo comportamento" (idem p. 14). A experiência anterior das crianças não é composta, senão, por suas vivências familiares e escolarizadas, por conceitos espontâneos ou por conceitos científicos em processo de apropriação. Como assinala Vigotski (ibidem), a imaginação e a criatividade são inerentes ao desenvolvimento psíquico humano, seja criança ou adulto. Quanto mais experiência de vida, mais são as possibilidades de criar, imaginar e fantasiar. Mediante criação e imaginação, ancestrais humanos são reconhecidos por essas crianças e por sua professora como sujeitos da história social e cultural humana.

Para ressaltar a relação entre criatividade da criança, sua experiência de vida e as mediações da professora, apresentamos a imagem abaixo, referente à outra ação proposta e realizada em aulas anteriores:

\section{Foto I - produção escrita de aluna}

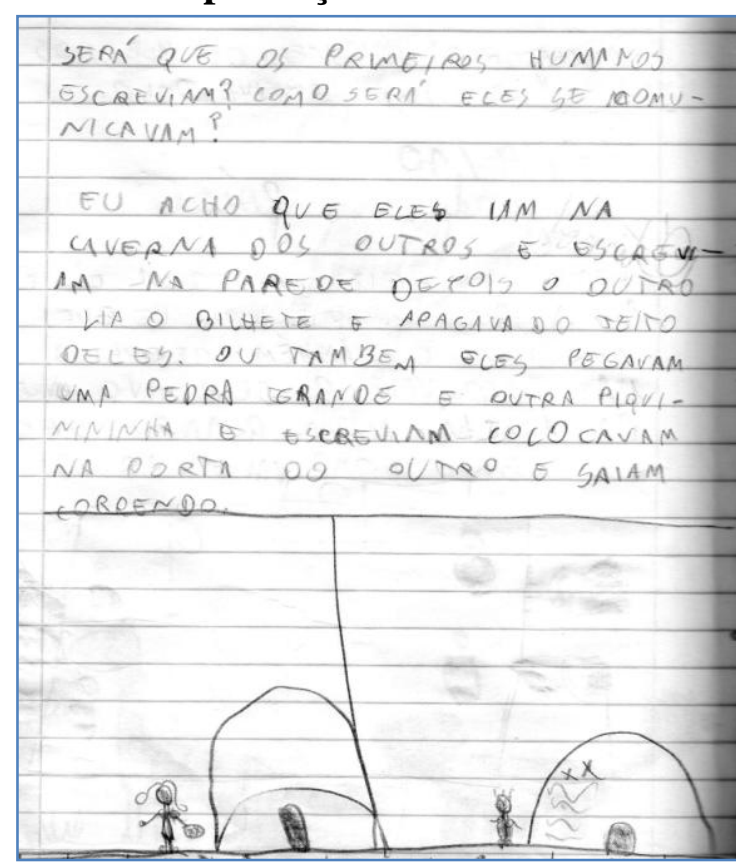

Será que os primeiros humanos escreviam? Como será que eles se comunicavam?

Eu acho que eles iam na caverna dos outros e escreviam na parede. Depois o outro lia o bilhete e apagava do jeito dele. Ou também, eles pegavam uma pedra grande e outra pequena e escreviam e colocavam na porta do outro e saiam correndo.

Aluna: Bianca $-2^{\circ} \mathrm{B}$. 
Para responder à pergunta formulada pela professora, a aluna Bianca imagina e cria com base em sua experiência de vida como criança, cujo conteúdo mais parece uma de suas brincadeiras. Para ela, os homens primitivos dominavam um modo de escrita, ainda que sobre pedras ou por meio de registros feitos nas paredes da caverna. O conteúdo de seu texto é uma mescla de certo jeito de brincar com informações adquiridas com seus colegas e professora.

A professora também mostra seu processo de criação e imaginação por meio de sua mediação discursiva, no caso a pergunta, oriunda também de sua experiência. $O$ texto elaborado por ela e materializado no caderno da criança não é senão a consubstanciação de seu deslocamento mental e temporal mediado por uma imagem, por sua vez, mediatizada por seu pensamento teórico a respeito das relações sociais estabelecidas entre os homens primitivos e sobre as formas pelas quais eles se comunicavam e registravam seus pensamentos.

Aliás, vale destacar o potencial de auto formação dessa mediação discursiva docente. A professora, ao garantir que as crianças se desloquem no tempo e no espaço, via criação e imaginação, faz mentalmente o mesmo processo. Os signos intermediadores da relação imagens conservadas em sua memória - de orientação interna, exercem sua ação reversa, retornando à mente da professora como função auto formativa, gerando também para ela possibilidades de imaginação e criação e, por suposto, o surgimento de operações psicológicas qualitativamente novas, importantes em seu processo de aprender a ensinar e de se desenvolver profissionalmente. Com isso, reafirmamos o pressuposto de Vigotski (2010, p. 33) de que o signo "possui, também, a característica importante de ação reversa (isto é, ele age sobre o indivíduo e não sobre o ambiente)".

Retornando ao curso enunciativo do episódio, notamos que as crianças também lançam mão de suas experiências e de sua formação cultural para falarem de vestimentas, aparência física e do modo como o homem da caverna produzia ferramentas e obtinha o fogo. Como exemplo de uma manifestação cultural, podemos recorrer à enunciação da aluna Bianca nos turnos 84 e 85 , em que ela, a partir do padrão de beleza contido em seu universo cultural, qualifica o homem da caverna como "parecido com o macaco" e "mais feio" do que o homem atual. Não somente ela, mas todas as outras crianças que sinalizam concordância ao responderem à pergunta enunciada pela professora, no turno 87. Mediante a pergunta "vocês concordam com isso?”, ela intenta levar as crianças à contraposição de opiniões, podendo assim verificar a existência ou não de padrões temáticos contraditórios entre seus alunos. 
Enfim, há uma imagem e um quadro em suas mentes, os quais municiam suas enunciações e mediatizam suas produções escritas.

No âmbito desse deslocamento mental, a professora possibilita que as crianças estabeleçam comparações não apenas entre o homem atual e o homem primitivo, mas entre espécies diferentes de homens primitivos. É o caso da aluna Geovana no turno 109 e do aluno Marcos no turno 110, que comentam sobre a existência, no passado, de homens com diferentes tamanhos de cabelos e de sobrancelhas. O processo de comparação é iniciado no turno 48 pelo aluno Vitor, ao responder à professora que aprendeu que eles (homens da caverna) eram diferentes de nós. Na verdade, a professora parte da resposta do aluno Vitor para sugerir outras perguntas e levar às demais crianças a estabelecer relações de comparação, importante para que sua necessidade de verificar o grau de aprendizagem a respeito seja resolvida e seu motivo/objetivo seja realizado. Essas relações de comparação estabelecidas com sucesso pelas crianças são indícios de tal realização docente.

Vamos agora para o último episódio da análise desta aula, o qual coincide com as últimas sequências de enunciações da roda de conversa. Sem dúvida, caracteriza-se como mais uma cadeia aberta de diálogos, cujos signos mediadores são perguntas e conhecimentos compartilhados pela professora com seus alunos. O engajamento dialógico continua marcado pela inter-relação entre as enunciações da professora e crianças. Entre uma enunciação e outra, a professora ora pergunta, ora enfatiza o que está sendo dito pelas crianças e vai complementando o padrão temático de sua aula.

\section{Episódio de ensino III - O que pode ser encontrado em um sítio arqueológico}

(19min: 12seg) 186. P - Então a gente conclui que no sítio arqueológico não tem só ossos e vestígios de seres vivos, tem também marcas deixadas pelos seres humanos, restos de ferramentas quebradas, vasilhas de cerâmicas quebradas. Então, em nosso sítio arqueológico não pode ter só esse tipo de fóssil de seres vivos, tem que ter esses vestígios também, não é isso?

187. Marcos - Emblemas.

188. P - Desenhos, emblemas como vocês falaram. Não só os fósseis, mas todos os vestígios que ajudaram a desvendar tudo.

189. João Vitor - Além dos desenhos eu fiz eles falando umas palavras muito esquisitas, chinês.

190. Marcos - Para eles desenharem e escreverem nas paredes, eles tinham que pegar tintas das árvores, fazer elas para desenhar.

191. P - Isso! A gente aprendeu que eles eram inteligentes e que eles inventaram tintas além das ferramentas. 
192. Gisele - Eles tiravam tinta do sangue do animal.

193. P - Isso. Algumas pessoas acham que eles faziam tintas com o sangue de animais.

194. Isabele - Eles pegavam a tinta com um pedaço de pau e pintavam as cavernas.

195. P - Tá vendo como eles criaram e fizeram marcas que a gente usa para estudar eles também?

196. Lucas - Professora, eu vi na televisão que os homens da caverna tinham escrito numa pedra enorme e que ficou até hoje.

197. P - Eh, ficou até hoje. Olhem, no Brasil não sei se vocês se lembram do que a prô falou pra vocês. Tem um lugar que se chama São Raimundo Nonato, na região NE do Brasil, que fica um parque que protege o maior sítio arqueológico do mundo, tá? Que mostra todas essas marcas dos homens das cavernas, dos primeiros homens que existiram. Eles deixaram muitas marcas lá. Então, têm esses emblemas, esses desenhos, têm restos de utensílios, têm restos de ferramentas. Então, infelizmente a gente não pode ir lá porque é longe, é uma viagem longa, enfim. Mas como J. Vitor falou que pesquisa na internet e tudo, quem se interessar tem esse lugar no Brasil, chama-se São Raimundo Nonato, tá? Lá fica o maior sitio arqueológico de seres humanos do mundo. Fica na cidade de São Raimundo Nonato. (22min: 45seg)

Destaca-se no episódio a ampliação do conceito de fóssil para além das ossadas de dinossauros. Compartilhar os conhecimentos de que vestígios humanos também são fósseis presentes nos sítios arqueológicos é o conteúdo da mediação discursiva docente, que marca a enunciação do turno 186. A professora pretende construir um modelo de sítio arqueológico junto com seus alunos e, para tanto, é necessário compartilhar o que é um sítio arqueológico e quais tipos de fósseis são nele encontrados. Esse é o foco do padrão temático deste episódio, enriquecido por informações trazidas pelas crianças de aulas anteriores sobre os primeiros modos de registro e comunicação humanos. Essas informações foram obtidas mediante a pergunta exposta no texto da aluna Bianca, inserido acima. Em resposta à mediação da professora ("Será que os primeiros humanos escreviam? Como será que eles se comunicavam?") foi consensual a ideia de que os desenhos feitos nas paredes das cavernas eram os principais modos de comunicação, também vistos como marcas ou vestígios importantes para os estudos atuais a respeito. Portanto, esses registros ou "emblemas", como foram denominados pelo aluno Marcos no turno 187, devem fazer parte do sitio arqueológico em construção, pois eles existem nos sítios reais, considerados como vestígios humanos que nos falam do modo de vida de nossos ancestrais.

Por final, a professora compartilha a informação sobre a localização de um sítio arqueológico situado na região Nordeste do Brasil. Ao falar desse grande sítio, não deixa de propiciar mais um deslocamento mental, agora apenas no contexto espacial ou de lugar. 
Como é um lugar distante, ela os orienta a conhecê-lo por meio de pesquisas na internet, modo pelo qual, possivelmente, ela teve acesso às informações transmitidas.

Outro aspecto a ressaltar é o papel da mediação discursiva docente na construção textual da conversação, ou seja, na construção do padrão temático em discussão. Ainda que muito simples, há um conjunto de significados em processo de construção pelas crianças, cujos nexos semânticos são delimitados pela mediação docente, mais precisamente pelas perguntas da professora. Há um pensamento teórico em construção mediante o curso enunciativo da professora e das crianças. Também nesta aula, devemos considerar que as crianças introduzem elementos teóricos e científicos importantes para compor o padrão temático.

Referimo-nos algumas vezes à mediação discursiva docente cujo objetivo é compartilhar conhecimentos ou compreensões. Recorremos a Edwards e Mercer (1988, p. 15) para justificar que o compartilhamento de conhecimentos ocorre quando duas ou mais pessoas sabem o que antes apenas uma sabia. No plano da filogênese, a nossa espécie assegurou o seu domínio sobre os demais animais por meio desse ato, o qual decorre, em grande medida, da capacidade de comunicação e subsequente desenvolvimento da linguagem inerente à formação humana. "Quando duas pessoas se comunicam, existe realmente a possibilidade de que, reunindo suas experiências, cheguem a um novo nível de compreensão mais alto do que o que possuíam antes", máxima defendida pelos autores supracitados.

Supomos então que houve compartilhamento de conhecimentos na aula em análise: crianças podem agora saber o que antes apenas a professora sabia; ou professora e crianças podem saber o que apenas uma das crianças sabia. Ou seja, supostamente crianças e professora sabem mais que antes. É o que constatamos no padrão temático exposto abaixo. 
Figura 13 - Padrão temático aula dinossauros e a pré-história humana.

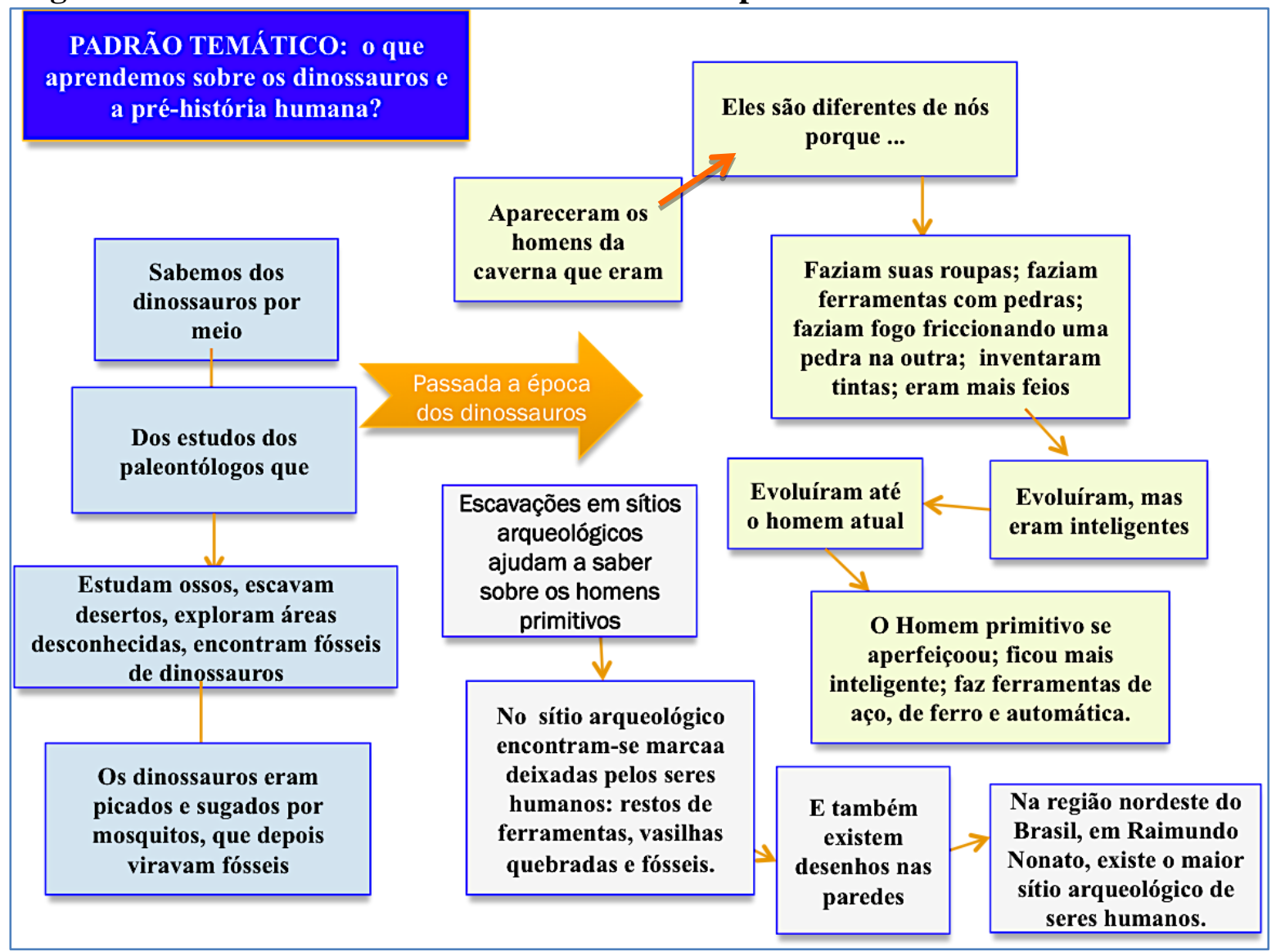

Fonte: Informações organizadas pela autora.

Em relação ao padrão temático exposto acima, reiteramos que ao falarmos de significados construídos ou apropriados pelas crianças, não os definimos como conceitos em sua estrutura sistêmica, e sim como pseudoconceitos, os quais diferem do conceito propriamente dito por sua essência e natureza psicológica (Vigotski, 2009b). Essas crianças, em uma proporção ainda maior que aquelas participantes das duas aulas anteriores, não têm consciência das relações semânticas existentes entre os termos e frases ditos por elas, pois não dominam as relações conceituais que explicam a existência e extinção dos dinossauros, o fenômeno da fossilização, e muito menos a teoria da Evolução das Espécies. Elas estão cursando o segundo ano de escolarização, em processo inicial de aprendizagem sobre como falar ciências, sobre como ler e escrever.

Outro aspecto a destacar se refere à visão da professora em relação ao conceito de Evolução das Espécies. Numa visão progressista, ela associa a ideia de evolução à ideia de progresso, ao afirmar que os homens da caverna evoluíram, e ficaram, não apenas diferentes, mas no curso da evolução eles foram se aperfeiçoando, melhorando e ficando mais 
inteligente, como complementa o aluno Marcos no turno 107 do $2^{\circ}$ episódio. Em nossa interpretação, no entendimento da professora, a palavra evolução conserva o sentido genérico de desenvolvimento progressivo, usado popularmente como um conjunto de mudanças qualitativamente positivas, diferente do sentido que lhe é atribuído no contexto epistemológico da área da Biologia, ao se discutir a teoria da Evolução. Nesse campo, a Evolução não é necessariamente progresso, e muito menos progresso unilinear e constante, mas qualquer mudança das características genéticas em uma população ao longo das gerações. Tal lacuna na formação da professora não se configurou como uma necessidade formativa, pois nenhuma contradição foi verificada no processo de compartilhamento de tal conhecimento entre ela e as crianças.

Para finalizar a análise dessa aula, apresentamos a síntese das mediações discursivas apreendidas no curso do fluxo discursivo.

\section{Figura 14 - Mediações discursivas e objetivos docentes - dinossauro e pré-história humana.}

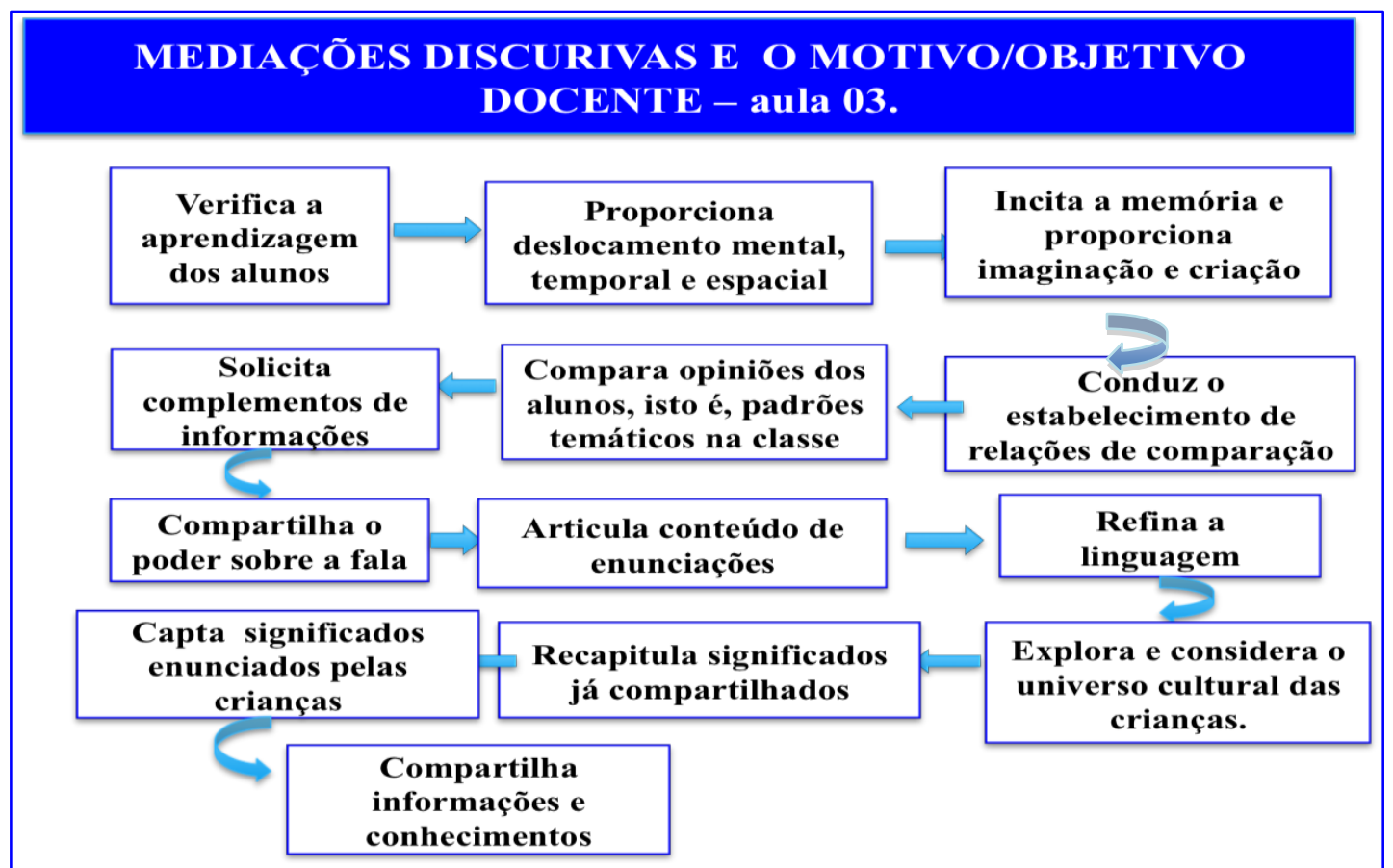

Fonte: informações organizadas pela autora.

O conhecimento sobre o conjunto de mediações discursivas, constatadas nesta aula e nas outras duas antecedentes, nos aproxima das respostas ao problema que orienta esta pesquisa. Para avivar nossa memória, repetimos a questão norteadora: o que a mediação discursiva docente pode mostrar sobre o trabalho docente e o desenvolvimento profissional de professores dos anos iniciais que ensinam ciências sob orientação investigativa? 
Lembramos que a mediação discursiva docente é a unidade de análise ou unidade de abstração, ou ainda como denomina Vigotski, a forma mais desenvolvida que, como tal, tem cumprido o significativo papel de nos conduzir à apreensão do real - essência da relação que buscamos estabelecer entre motivos e sentidos docentes e o desenvolvimento profissional.

A mediação discursiva, tomada como fio condutor, mostrou-nos elementos importantes do trabalho docente, sobre o modo geral de ação da professora, composto pelos variados modos de mediação interpostos nas relações entre o seu objetivo de ensino e o processo de aprendizagem de seus alunos - síntese que iniciamos a seguir.

\subsection{Síntese: sobre as mediações discursivas docente}

\subsubsection{Mediações discursivas e o modo geral de ação da professora Verônica}

A mediação discursiva de maior destaque nas três aulas foi o fazer perguntas. Aliás, o modo de mediação mais frequente é a pergunta, proferida mediante a expressão de diferentes motivo/objetivos: sintonizar seus motivos com os dos alunos; verificar aprendizagem; recapitular ações; reafirmar assertivas; avaliar negativamente as respostas; problematizar enunciações dos alunos; refinar a linguagem dos alunos; inter-relacionar uma enunciação com outra; tornar uma enunciação mediadora de outra; manifestar dúvida e/ou surpresa; compartilhar conhecimentos; controlar o fluxo discursivo; controlar a gestão da classe; dirigir a atenção dos alunos; conduzir o estabelecimento de relações; criar contextos mentais, entre outros.

Alguns desses papéis delegados à pergunta são validados pela própria professora:

Eu acho assim que quando eu pergunto é uma maneira de eu estar meio que avaliando o meu aluno pra ver o que ele sabe. Quando é pra isso, o meu objetivo é um; quando eu quero levantar os conhecimentos prévios deles, vamos supor, eu faço um monte de perguntas com um objetivo; agora quando é uma roda de conversa pra encerrar o que eu trabalhei, aí eu quero saber se ele aprendeu mesmo aquilo. (EII, 2011) 
Em relação às perguntas enunciadas pela professora, assumimos a nossa dificuldade em qualifica-las como de instrução ou como autênticas, pois, de maneira geral, elas não seguem estritamente o padrão triádrico I-R-E e nem apresentam características puramente autênticas. Algumas delas são de fato de instrução, cujo objetivo, descrito acima pela professora, é de avaliação da aprendizagem do aluno; outras, a maioria, poderia ser enquadrada numa categoria intermediária, como quase autêntica, por exemplo, pois nem sempre geram respostas previsíveis, sem falar no campo aberto ao diálogo garantido por elas no processo de conversação. Esse campo aberto ao diálogo pode ser notado no grande número de enunciações das crianças nas três aulas e na qualidade das tantas perguntas autênticas enunciadas por elas.

Enfim, a professora pergunta com a intenção de realizar seus motivos e objetivos. Esse sentido atribuído à pergunta é confirmado por ela, ao enunciar sua predileção por esse modo de mediação, conferida em suas próprias palavras: “(...) eu acho que quando eu pergunto eu ajudo eles. Não sei se é certo, ou errado. Pela experiência, eu acho que eles chegam porque eu acho que eu vou instigando e a resposta de um ajuda o outro a pensar, não sei” (EII, 2011). Ao atentar para sua própria experiência, ela conclui que instigar as crianças via perguntas pode ser um caminho para conduzi-las à apropriação de significados.

Entretanto, não apenas a professora em análise delega papel de mediação às perguntas. Ao revisitarmos a literatura a respeito, vimos que professores que desejam estimular a discussão em classe costumam, realmente, fazer muitas perguntas, as quais "formam parte do armamento discursivo de que dispõe o professor para controlar temas de discussão, dirigir o pensamento e ação dos alunos e estabelecer os limites da atenção compartilhada, da atividade conjunta e do conhecimento comum” (Edwards \& Mercer, 1988, p. 62).

Souza (2012) corrobora com tal inferência ao apresentar resultados sobre a qualidade e importância das perguntas docentes em aulas investigativas de Física, e relacionar tais perguntas com o objetivo de alfabetizar cientificamente os alunos. Para esse autor, em uma aula organizada e desenvolvida via atividade investigativa, as perguntas do professor encerram qualidades como "perguntas de problematização", "perguntas sobre dados", "perguntas exploratórias sobre processos" e "perguntas de sistematização". Em suas conclusões, tais qualidades de perguntas podem ser consideradas como indicadores de alfabetização científica dos alunos. 
As qualidades das perguntas presentes nos resultados do estudo de Souza (2012) estão entre as qualidades daquelas enunciadas pela professora Verônica, as quais, somadas aos demais modos de mediação, mostram elementos que aproximam o seu modo geral de ação aos elementos teórico-práticos próprios da orientação investigativa adotada para o ensino de ciências na escola.

Os elementos característicos de tal orientação são imanentes aos modos de ação docente e à estrutura geral da atividade. Atividades organizadas sob tal orientação apresentam perguntas qualificadas como situações desencadeadoras também denominadas de problemas de aprendizagem, os quais guardam em sua essência uma necessidade cognitiva, a ser realizada e materializada no caminho percorrido pelo aluno para satisfazê-la, isto é, no processo de aprendizagem do conceito correspondente.

As três aulas analisadas se constituem em ações desencadeadas para resolver problemas de aprendizagem, cada qual munido de sua necessidade correspondente aos significados a serem apropriados pelos alunos. O submergir e o emergir do submarino e a flutuação de corpos são a base conceitual dos problemas desencadeadores das ações circunscritas à primeira e à segunda aula, respectivamente; a terceira aula trata-se de uma base mais ampla, por envolver conhecimentos sobre paleontologia, mais especificamente sobre dinossauros e modos de viver dos ancestrais da espécie humana.

Portanto, talvez a preferência pela pergunta como modo de mediação identificada no modo geral de ação da professora Verônica possa ser relacionada com a orientação mediante a qual ela busca organizar o ensino de ciências. Ou talvez, como ela própria diz, seja um modo validado por sua experiência, como tal, conscientizado de dialogar como seus alunos, de obter respostas quanto à sua necessidade de ensinar e de realizar seu motivo/objetivo, isto é, de criar oportunidades de aprendizagem.

Com a configuração das mediações discursivas da professora Verônica, verificamos que além das perguntas e objetivos associados a esse modo de mediação, outros signos e instrumentos são integrados às suas diferentes ações. Cada objetivo intrínseco à ação tem suas peculiaridades e exige signos e instrumentos específicos, como por exemplo: a experimentação adotada como estratégia de investigação realizada para resolver problemas de aprendizagem requer materiais e signos específicos relacionados à necessidade cognitiva implícita no problema de aprendizagem; rodas de conversa ou trabalhos em duplas ou em 
grupos requerem organização específica do espaço condizente com o objetivo docente, além de signos e instrumentos próprios, como livro-texto, marca-texto, significados diferenciados, entre outros; leituras de qualidades diferentes de textos e escritas espontâneas são outras ações, todas elas integradas à linguagem como signo mediacional. Em suma, cada mediação discursiva encerra ações integradas a signos e objetivos específicos.

Outro aspecto importante a ressaltar é o modo como a professora Verônica gerencia sua classe. Nota-se no transcurso das três aulas analisadas um clima de descontração nas conversas, flagrado no envolvimento das crianças, principalmente em seu humor, demonstrado em suas frequentes risadas. Esse clima revela o quanto o padrão de relacionamento é favorável ao processo de comunicação.

Falar e ouvir são, seguramente, funções psicológicas superiores em propenso desenvolvimento para toda a vida do sujeito, mas sem dúvida, se destacam no processo de formação intelectual das crianças. Tais funções são valorizadas pela professora Verônica, como foi possível verificar tanto em suas mediações como em seu depoimento enunciado em uma de suas entrevistas: “(...) eu nunca gostei de sala quieta, eu falo, o aluno fica quieto, eu sempre gostei de diálogo mesmo (...)" (EI, 2010).

Não há dúvida de que os motivos e sentidos da professora marcam suas mediações discursivas, o que é coerente com a ideia de que as mediações não são neutras. Não podemos esquecer de que as palavras são signos ideológicos, como tal, carrega e transfere para o aluno em aprendizagem, concepções de como o professor entende o mundo e de como concebe a formação dos sujeitos sob sua responsabilidade.

Tais concepções não são senão o sentido atribuído pela professora à sua atividade docente, o de ensinar, de modo que seus alunos aprendam, isto é, o de "tornar o aluno uma pessoa mais questionadora, que tenha opiniões", o de "formar mesmo as pessoas para serem seres políticos" (Prof ${ }^{a}$ Verônica - Narrativa sobre a trajetória formativa e profissional - texto no corpo da tese). Tal sentido, coerente com a função social da docência, é o conteúdo político e ideológico dos signos integrados pela professora Verônica às suas ações, cuja integração compõe suas ações mediadas, o que aqui denominamos de mediação discursiva. Isso significa dizer que esse conteúdo ideológico está no sujeito, em seus pensamentos verbalizados e materializados em cada signo e em cada instrumento, isto é, em cada ferramenta cultural. 
Tal como já mencionamos, os modos de mediação transmitem as relações de poder e autoridade mediante as quais a professora rege a gestão de sua classe ou controla as relações de comunicação entre seus alunos. O poder e a autoridade são determinados pela não neutralidade dos modos de mediação, por sua vez, explicada pelo sentido ideológico inerente às escolhas deliberadas pelo sujeito. O sentido ideológico da professora Verônica materializase nos modos de mediação escolhidos por ela para por em prática suas ações, o que implica na aparente relação que há entre cada signo/instrumento e o caráter objetal da atividade, na qual suas ações são inseridas.

A palavra, como signo ideológico regula a estrutura hierárquica da conversação, condicionada também pela qualidade do discurso docente. As relações hierárquicas presenciadas nas aulas da professora Verônica, embora assimétricas, podem ser consideradas como dialógicas, sobretudo nas aulas 01 e 03, cuja voz da criança se faz presente e, em muitos momentos, dá o tom e o ritmo da conversa. Ouvir a criança e garantir a sua participação na aula faz sentido para essa professora.

Nas conversações aqui apresentadas, as crianças ganham a palavra e também interpõem signos nas ações mediadas, com possibilidades de gerar pontos de inflexão na linha que demarca a curvatura das relações de poder que regem a conversa. Ao longo de uma aula, esse ponto muda constantemente de posição, ora mais próximo da professora, ora posicionado mais para o lado dos alunos. O que notamos é que a participação do aluno está, em certa proporção, condicionada ao grau de compartilhamento do poder, sendo esse compartilhamento dependente do conteúdo ideológico das mediações discursivas docente, isto é, da qualidade dos modos de mediação interpostos entre a docente e os alunos.

Há momentos em que o poder é mais e menos compartilhado, cujos papéis de cada participante estão previamente definidos: à professora cabe o papel de mediar a conversa entre uma criança e outra e entre ela e a classe, e apenas ela pode intervir sem precisar pedir a palavra; às crianças cabem participar sob mediação da professora: para ganhar a palavra, é preciso levantar o braço e esperar a sua vez de falar. Parece ser uma relação já naturalizada no grupo, não requerendo autoridade no discurso docente para manter rigidamente controle disciplinar.

O discurso da professora seria qualificado por Bakhtin (2010) como discurso persuasivo, pois no espaço de comunicação criado, locutores e ouvintes tornam-se interlocutores, sem que um rejeite a palavra do outro. O contrário disso seria o discurso de 
autoridade, cujo princípio emanado seria a distância imposta entre a palavra de quem fala e a de quem ouve.

A naturalização das relações é construída por meio de motivos gestados a cada dia e por meio de sentidos coletivos decorrentes desses motivos. Com base em Wertsch (1999), a professora conquistou determinado status de personalidade que merece confiança e respeito, a quem as crianças decidiram escutar e respeitar. $\mathrm{Na}$ verdade, ela exerce, sob reconhecimento das crianças, o papel que lhe é delegado historicamente e socialmente - o de docente mediadora do processo de aprendizagem. Sabemos que esse reconhecimento não é simplesmente posto, de fato resulta de relações construídas dia após dia, do estabelecimento de pactos, acordados sob vontades e interesses mútuos, isto é, sob motivos e sentidos gestados conjuntamente.

Esse pacto, denominado por Paulo Freire de "disciplina do silêncio", se constitui, na verdade, como um processo de reeducação dos sujeitos, da conquista paulatina da garantia do espaço da comunicação, tanto para quem ouve como para quem fala. Como diz Freire (2001), o silêncio no espaço da comunicação possibilita a quem ouve entrar no movimento interno do pensamento de quem fala; e a quem fala, escutar as indagações e criações de quem está a lhe ouvir. Freire interpreta senão um processo de dialogia, tal qual defende Bakhtin, como esse conceito é adotado neste trabalho.

O certo é que a professora Verônica consegue estabelecer esse pacto, assegurando a comunicação entre ela e seus alunos. Transparece em suas mediações um misto de firmeza com delicadeza combinado a agradáveis oportunidades de aprendizagem criadas para as crianças. Segundo a professora, esse método foi herdado de sua experiência como aluna da Dona Arlete, sua professora do $3^{\circ}$ e $4^{\circ}$ ano primário. As memórias da professora Verônica guardam a seriedade do modo de ensinar de Dona Arlete, presente como traço importante em sua personalidade docente, aparente em seu modo de ensinar.

Certamente a professora Verônica também deixa marcas na mente de seus alunos com o conteúdo de suas mediações discursivas, com as oportunidades de aprendizagem que lhes proporciona e com o seu próprio modo de se interpor como adulto mais experiente, entre eles e o processo de aprendizagem. Justificamos essa possibilidade com a tese marxista apropriada por este trabalho, a de que o objeto de trabalho, uma vez transformado, incorpora elementos da natureza de quem o transformou. Faz sentido, portanto, dizer que a classe de nossa professora, o modo como seus alunos se organizam e atuam, expressa o seu modo de organização e ação. Talvez alguns de seus alunos carreguem e incorporem em sua experiência 
de vida elementos de sua vivência escolar, tal como ocorreu com a professora em relação à Dona Arlete.

Enfim, traçamos brevemente o modo geral de ação da professora, o modo pelo qual ela ensina seus alunos a falar ciências, aliás, não apenas ciências, mas a falar a cultura oriunda da experiência sócio histórica da humanidade. Na verdade, a professora ensina seus alunos para lhes garantir o desenvolvimento de novas funções psíquicas, para que eles se apropriem e dominem a linguagem (signos e instrumentos), pois, como escreve Leontiev (1978, p. 327), apropriar-se da linguagem é a "condição mais importante do seu desenvolvimento mental". Sem a linguagem não há comunicação, não há como falar e escrever palavras com significados. Afinal, a comunicação, seja na forma verbal ou sob qualquer outra forma, “(...) é a condição necessária e específica do desenvolvimento do homem na sociedade" (idem, 1978, p. 272).

Esse modo geral de ação combinado às informações municiadas pela narrativa da trajetória formativa e profissional da professora nos possibilita concluir sobre a correspondência que há em sua consciência entre o sentido atribuído por ela à sua atividade docente com a função social da docência. Motivos e sentidos docentes identificados em seus depoimentos, com os quais nós construímos a narrativa, foram confirmados a partir da análise que fizemos de suas mediações discursivas. Portanto temos elementos para situa-la no plano de resistência à condição de alienação, no plano de construção de sentidos favoráveis a não dissociação entre o seu processo de apropriação de conhecimentos e a sua prática de sala de aula, isto é, no plano de construção de sentidos favoráveis à construção de sua atividade docente como práxis. Como tal, favorável ao seu desenvolvimento profissional.

Ao situar a professora em um plano de resistência à alienação, estamos falando do estágio de desenvolvimento, no qual ela se encontra, o que significa reafirmar a sua predisposição em construir sua docência como atividade humana. De acordo ao que afirma Marx (2010), apenas como atividade humana ou práxis, uma atividade laboral gestaria as melhores condições para o desenvolvimento humano e profissional. Portanto, apenas na condição de práxis pedagógica, a docência se constituiria no plano mais favorável a desenvolvimento profissional docente; apenas sob tal condição a professora Verônica vivenciaria plenas possibilidades formativas. Com essa ressalva, reiteramos a sua condição de ser humano inconcluso e em permanente desenvolvimento.

Após essa ressalva, destacamos outra não menos importante: a professora não gesta motivos, não constrói sentidos sozinha, por conseguinte, não se desenvolve sozinha, isolada 
do contexto de trabalho de sua escola e da realidade social na qual está inserida. Aliás, a nosso ver, colocar-se em um contexto de superação da alienação isoladamente é humanamente impossível, pois resistir aos fatores objetivos e subjetivos que impactam o trabalho docente na atualidade não é tarefa para uma pessoa, ao contrário, requer agrupamentos e estabelecimento de parcerias na escola e fora dessa instituição.

De fato, a professora Verônica não está sozinha. Suas mediações discursivas já nos mostraram isso. E nem os ensinamentos de Dona Arlete são as únicas vozes contidas em suas memórias. Inserida em um sistema coletivo de atividade, portanto, em um sistema multivocal, não pode ser vista como um sujeito puramente individual, ainda mais se lembramos da tenuidade ou quase inexistência do limite que há entre o individual e o social. Como afirma Wertsch (1999, p. 173) toda ação humana está situada socioculturalmente exatamente porque os modos de mediação são parte de "qualquer âmbito cultural, histórico e institucional". Mesmo as ações realizadas no plano intramental, como o pensamento, por exemplo, não prescindem das ações intermentais. Ambos os planos, intramental e intermental, estão interrelacionados, o que diz da permeabilidade da fronteira que os separa. Não é demais repetir que as funções intramentais (funções psicológicas superiores) sua composição, estrutura e modos de mediação têm sua gênese nas relações sociais (Vigotski, 2009 a).

Sendo assim, é válida a abordagem sobre quais vozes se fazem presentes na sala de aula da professora e como essas vozes contribuem com a realização dos motivos que lhe impele a ensinar, por conseguinte, quais vozes contribuem com a construção dos seus sentidos.

\subsubsection{Mediações discursivas docentes e as comunidades vocais no sistema coletivo de atividade}

Não será possível abordar todas as comunidades vocais do sistema coletivo de atividade $^{19}$, no qual a professora Verônica se insere. Abordamos somente aquelas que influenciam mais diretamente o trabalho da professora Verônica, em especial as comunidades explícitas no movimento dialógico das três aulas analisadas ou as citadas em suas enunciações por ocasião das reuniões e em seus depoimentos que compõem as entrevistas.

${ }^{19}$ Figura 08 , página 107 , no corpo desta tese. 


\subsubsection{Multivocalidade da sala de aula}

Esta investigação privilegia a sala de aula como a comunidade vocal mais importante do sistema coletivo de atividade em análise - ensino de ciências nos anos iniciais, com destaque para as vozes presenciais das crianças, alunos em dialogia com sua professora.

A princípio, afirmamos que as crianças, não apenas suas perguntas, mas suas diferentes intervenções são enriquecedoras do processo de ensino-aprendizagem. Para termos noção de tal riqueza, basta que imaginemos essas aulas sem o humor, a alegria, as belas enunciações e sem as perguntas autênticas das crianças: teríamos aulas silenciosas e a voz predominante da professora lendo em voz alta ou transmitindo informações para alunos; em tal circunstância, para as crianças restaria apenas o papel de ouvinte. Estaríamos, certamente, assistindo aula ministrada por outra professora, cujas mediações discursivas teriam outros conteúdos e objetivos. Conteúdos que poderiam não levar ao compartilhamento de compreensões e nem à partilha da dúvida e da responsabilidade pela busca de conhecimentos.

Aliás, vale uma pausa para relembrarmos os significados dos conceitos compartilhar e compreender por serem tão caros à construção deste trabalho: compartilhar seria mais que realizar uma atividade conjunta, seria aprender com o outro mediante uma atividade conjunta, isto é, o conhecimento ou a compreensão é compartilhado quando após uma atividade, realizada conjuntamente, participantes passam a saber o que antes apenas uma ou poucas pessoas sabiam (Edwards \& Mercer, 1988); a compreensão, por sua vez, situa-se na raiz da dialogia, em um processo em que a palavra de um falante é combinada a palavra do outro; a voz de um é valorizada pela voz do outro (Bakhtin, 2010). Portanto, em tal dimensão, com a associação desses dois conceitos - compartilhar compreensões - ganhamos a possibilidade de expressar com mais significado o alcance do objetivo referente à apropriação de significados pelos participantes, pelos alunos e professora.

A nosso ver, houve compartilhamento de compreensão nas aulas da professora Verônica, com acentuada participação das crianças, inclusive com a introdução de informações e conhecimentos por elas. Em relação a isso, nos apoiamos mais uma vez no trabalho de Souza (2012), em uma das ressalvas contida nas considerações finais, a de que não apenas as perguntas docentes são profícuas ao objetivo de alfabetizar cientificamente, mas também as perguntas dos alunos podem contribuir com o cumprimento desse papel. Tal ressalva torna-se significativa para este trabalho por considerarmos as perguntas autênticas das crianças como elementos que valorizam e potencializam a comunicação e, por 
conseguinte, o fluxo do movimento dialógico discursivo. Como já discutimos anteriormente, os padrões temáticos discorridos ao longo das aulas foram construídos com a colaboração das crianças.

Diante disso, perguntamos: as enunciações das crianças favorecem a realização dos objetivos docentes e a construção de sentidos? Respondemos que sim; e se fôssemos muitos, responderíamos em coro, tal qual elas próprias fazem, ao responderem as perguntas de sua professora. O coro seria para enfatizar o quanto as enunciações das crianças, sobretudo suas perguntas autênticas, contribuem para que o objetivo de garantir sua própria aprendizagem se realize. O êxito na aprendizagem é também êxito do trabalho docente, visto como uma das fontes que realimenta a construção do sentido atribuído pela professora à sua atividade pedagógica.

As vozes das crianças, sobretudo suas perguntas autênticas, também são responsáveis, em certa proporção, por inserir dúvidas e por revelar necessidades formativas da professora. Queremos tão somente dizer que as crianças contribuem com a aprendizagem docente, se não com a introdução de elementos teóricos e formação do pensamento teórico da professora, com a construção de motivos de aprendizagem, ao gerarem a necessidade de estudos, de pesquisas e de conversas com pessoas com mais conhecimentos sobre determinado assunto, condição necessária para que situações de aprendizagem sejam instauradas e as respectivas necessidades satisfeitas.

\subsubsection{Processos formativos: grupo escola e parceria colaborativa com a} universidade - vozes virtuais na sala de aula

As vozes do grupo da escola, em nome da coordenadora e demais parceiras de trabalho, não aparecem explicitamente no fluxo discursivo da sala de aula, mas são referenciadas nos depoimentos da professora enunciados nas entrevistas e reuniões.

No cotidiano da escola, a coordenadora posiciona-se como ponto de apoio, a quem a professora recorre quando diante de dúvidas surgidas em classe ou no processo de planejamento: 'É, até a pergunta que eu ia fazer eu perguntava pra ela, ó: é de acordo, é esse tipo de questionamento que eu tenho que fazer, ou não, né? Sempre trazia isso pra ela... aí, ela, geralmente colaborava 'não... é isso mesmo, pode fazer!'” (EI, 2010). 
A dificuldade exposta pela professora insere-se entre os elementos teóricos e metodológicos que perfazem a orientação metodológica em processo de apropriação por ela a formulação do problema de aprendizagem ou situação desencadeadora. A elaboração do problema requer consciência sobre a necessidade cognitiva que constitui sua essência, por suposto, sobre o motivo nele implícito, cujo papel é colocar as crianças em ação. Como escreve Saviani (1996, p. 13)

(...) uma questão em si não caracteriza o problema, nem mesmo aquela cuja resposta é desconhecida; mas uma questão cuja resposta se desconhece e necessita conhecer, eis aí um problema. Algo que eu não sei não é problema; mas quando eu ignoro alguma coisa que eu preciso saber, eis-me, então, diante de um problema. (grifos nossos).

O sentido atribuído pela professora ao caráter do problema de aprendizagem tem em sua essência a complexidade mostrada por Saviani, o que justifica, na situação exemplificada, o seu cuidado ao solicitar ajuda para elaborá-lo. Em outras palavras, diríamos que a elaboração de um problema de aprendizagem requer atividade conjunta.

Atividades conjuntas ocorrem entre a professora e a coordenadora, aqui configuradas como situações de aprendizagem, que, por serem conjuntas e responderem a necessidades de ambas, apresentam potenciais de incidência sobre suas ZDPs. Aprender uma com a outra é um fato inerente ao trabalho docente, realizado coletivamente, correspondente à necessidade de aprendizagem e de desenvolvimento profissional das duas docentes.

De acordo com conteúdos enunciados pela professora na primeira entrevista (EI, 2010), essas atividades conjuntas ocorrem mediante diferentes vias: correio eletrônico, telefone e encontros presenciais no corredor da escola, no laboratório de ciências e até mesmo no momento em que a professora está em classe com seus alunos. Elas também se encontram no grupo de estudos coletivos, onde as discussões abrangem as demais parceiras de trabalho.

O sentido atribuído pela professora ao grupo da escola merece destaque. Para ela, esse grupo é o espaço, por excelência, que garante estudos e discussões: “(...) eu tenho certeza, que a gente tem que trabalhar em grupo. Eu acredito nisso, porque é dentro de um grupo que você aprende, (...) é lógico que na sala de aula individualiza, né? Porque cada professor tem sua prática, a realidade do aluno, mas a discussão em grupo é importantíssima...” (EI, 2010). 
Tal sentido é coerente com os pressupostos construídos ao longo desta pesquisa - o trabalho docente, seus motivos e sentidos, se constituem a cada dia, a partir do trabalho coletivo desenvolvido na escola mediante ações, tais como: busca conjunta de soluções para problemas de ensino; elaboração coletiva de atividades de ensino; estudo e análise entre pares de propostas de atividades de ensino; avaliações conjuntas sobre trabalho desenvolvido em sala de aula, entre outras.

Para que esse conjunto de ações componha a atividade coletiva das docentes envolvidas, é imprescindível que haja compartilhamento entre seus motivos e objetivos, e que haja também compartilhamento do produto de seu trabalho. Em tal circunstância, a aprendizagem dos alunos torna-se um produto coletivo, o que implica assumir o caráter de coletividade intrínseco ao sentido construído a partir da realização dos motivos. Ainda que guardemos as proporções referentes à individualidade de cada sujeito, ressaltamos a relação que há entre a realização conjunta do motivo e objetivo circunscritos à atividade, no qual as professoras estão inseridas, e a construção de sentidos coletivos. A qualidade desses sentidos garante e impulsiona a continuidade da participação coletiva, importantíssima para a ampliação gradativa do núcleo de resistência subsistente na escola à condição de alienação do trabalho docente.

Resistir coletivamente à condição de trabalhadores alienados pode significar a aproximação das professoras aos signos teóricos e a outros modos de mediação que, por ventura, estejam separados ou alienados de suas práticas. O retorno desses signos pode implicar na aproximação entre a atividade teórica e a prática, condição sem a qual a construção da docência como práxis estaria comprometida. Como práxis, a docência seria regida pela correspondência entre sentidos e significação social, refletida nos planos da consciência coletiva e no plano subjetivo de cada professora.

A professora Verônica é um dos sujeitos participante desse coletivo, cujas vozes compõem sua memória e comparecem em sua sala de aula, ainda que não verbalizadas, mas materializadas em suas ações resultantes de estudos e planejamentos coletivos. Portanto, o grupo da escola não apenas colabora com a realização de seu motivo/objetivo, mas o realiza conjuntamente, com contribuições sobre a construção de seus sentidos, condizentes com necessidades coerentes com o seu desenvolvimento profissional. 
Lembramos que o citado grupo coletivo de trabalho, uma vez inserido no sistema coletivo de atividade, inter-relaciona com as demais comunidades vocais, entre elas, o processo formativo instituído na escola por ocasião da parceria com a universidade, posto em prática mediante os encontros formativos (fórum I e fórum II). Em um movimento de mão dupla, gera contradições e sofre efeitos de contradições geradas por si e por outras comunidades, como aquela que localizamos entre os objetivos desses processos formativos. Retomamos a discussão sobre tal contradição para situar seus prováveis efeitos no plano do sistema coletivo de atividade. Para tanto, vamos recorrer à Daniels (2003, p. 124):

\begin{abstract}
As contradições não equivalem a problemas ou conflitos. São tensões estruturais historicamente acumulativas nos sistemas de atividades e entre eles. (...) Quando um sistema de atividade adota um novo elemento de fora (por exemplo, uma nova tecnologia ou um novo objeto), ele causa uma contradição secundária agravada, em que algum antigo elemento (por exemplo, as regras ou divisão de trabalho) colide com o novo. Essas contradições geram perturbações e conflitos, mas também renovam tentativas de mudar a atividade (Daniels, 2003, p. 124).
\end{abstract}

Em acordo com Daniels, identificamos os elementos introduzidos no sistema pelas ações da parceria como elementos novos, porém adotados e acolhidos pelo sistema, o que, apesar de neutralizar a possibilidade de colisão, não elimina a geração de perturbações e conflitos. Esses elementos novos são recebidos de modo diferente por cada sujeito, a depender de como cada um apreende e compreende a contradição e os níveis de conflito e perturbações gerados por ela. Essa apreensão e compreensão estão relacionadas ao grau de inserção e envolvimento de cada sujeito com o trabalho coletivo, o que invariavelmente reflete nos passos dados em seu processo de desenvolvimento profissional.

Há ainda outro aspecto que pode favorecer a neutralidade da contradição no âmbito desse sistema que pode explicar o envolvimento de muitos sujeitos da escola com as ações da parceria, entre eles a professora Verônica. Os espaços constituídos foram validados, sobretudo pelo conteúdo das discussões realizadas nos respectivos fóruns, as quais abrangeram não apenas a introdução de elementos teóricos, mas a combinação destes com necessidades pautadas pelas próprias professoras, manifestadas mediante relatos e reflexões sobre ações realizadas em sala de aula. Essas pautas constavam temas como gestão e organização espacial da classe, alfabetização na língua materna, leitura, escrita, dúvidas sobre conhecimentos 
específicos relativos ao ensino das Ciências Naturais, além de discussões sobre o ensino em outras áreas.

Entretanto, vale destacar que tal abrangência não se deve apenas à iniciativa da equipe da universidade, mas, sobretudo às imposições do grupo da escola, ao exigir, por exemplo, como condição para a aplicação das atividades das sequências, a constituição dos fóruns formativos, principalmente o fórum II ocorrido na universidade com a participação de professores de outras áreas. Ou seja, a contradição acima localizada também foi neutralizada pelas peculiaridades e princípios do grupo escola e pela atuação conjunta entre formadoras da universidade, professoras e coordenadora da escola ao longo de três anos.

Após esse parêntese, voltamos para o questionamento central: as ações da parceria, localizadas na multivocalidade do sistema coletivo de atividade, contribuiu para o desenvolvimento profissional da professora Verônica? Embora não possamos quantificar avanços, defendemos que sim, a considerar o seu grau de atuação e comprometimento ao longo dos trabalhos. Favorável a essa consideração é a ideia também defendida por Daniels (2003), de que a voz de um sujeito ressoa e age sobre a ZDP dos demais, o que significa dizer que os efeitos sobre o desenvolvimento da professora não têm sua gênese apenas na voz das formadoras da universidade, mas em todas as vozes ressoadas na amplitude multivocal de cada encontro formativo.

Em outras palavras, o curso do seu pensamento em direção à formação de suas funções intramentais origina-se das relações intermentais estabelecidas no âmbito do seu convívio social na escola, seja com seus alunos ou diretamente com alguma de suas parceiras de trabalho, ou com o grande grupo, onde se inserem as relações entre as muitas vozes das várias comunidades, entre elas, as vozes emanadas dos encontros formativos realizados com as formadoras da universidade.

Por efeito, concluímos com a ideia de que a parceria, inserida em um sistema coletivo de atividade, portanto, em ações conjuntas às demais comunidades desse sistema, contribuiu com a construção de sentidos com conteúdos que favorecem a superação da alienação do coletivo docente. A abrangência social e cultural, imanente a esse sistema, extrapola a formação do professor, como indivíduo, por potencializar o núcleo de resistência à condição de alienação da profissão docente, representado pelo grupo da escola, constituído, 
sem dúvida, nos espaços forjados pelas contradições inerentes ao movimento macrossocial, na qual a escola está inserida.

\subsubsection{Mediações discursivas e o desenvolvimento profissional docente}

Estamos caminhando, cada vez mais próximos à finalização deste trabalho. Como orienta o problema em investigação, tomamos a mediação discursiva para conhecermos o trabalho docente da professora em análise para, a partir desse conhecimento, focalizarmos o seu desenvolvimento profissional. Reafirmamos o pressuposto de que o trabalho docente, concebido como atividade, cria necessidades formativas, por assim dizer, desencadeadoras de situações de aprendizagem, as quais podem mediar o processo de desenvolvimento profissional.

Essa dimensão do trabalho docente está na base teórica e metodológica desta investigação, assumida na análise da atividade docente realizada em sala de aula por meio da mediação discursiva. Nessa base teórica encontramos subsídios para a construção das categorias orientadoras da análise para discutir os resultados relativos ao desenvolvimento profissional, tais como: motivos e sentidos docentes e importantes elementos, como necessidades formativas e indícios de desenvolvimento profissional. Passamos, então a discussão dos resultados:

\subsubsection{A realização dos motivos/objetivos docentes culmina com a construção de} sentidos favoráveis ao desenvolvimento profissional

Começamos com a afirmação de que é possível falar de objetivos, motivos e sentidos docente, olhando o movimento dialógico discursivo em sala de aula. A professora, ao se interpor entre o objetivo da atividade, isto é, entre o conhecimento que deseja ensinar e o processo de aprendizagem da criança, lança mão de diferenciados modos de mediações para atingir esse objetivo. Por isso afirmarmos que a essência de cada mediação discursiva contempla o motivo docente, aparente no objetivo realizado em cada ação.

Decorrem dessa premissa outras duas não menos significativas: a de que a realização de cada objetivo condiz com a realização do motivo; e a de que a realização do motivo resulta na construção de sentidos. Tais ideias básicas são inspiradas na relação de interdependência 
que há entre motivos e sentidos, defendida por Leontiev (1983, p.230): “O desenvolvimento dos sentidos é um produto do desenvolvimento dos motivos da atividade".

Perguntamos, porém: qual relação pode ser estabelecida entre a realização de objetivo/motivo/sentido e o desenvolvimento profissional docente?

Primeiro, vamos reafirmar a ideia de que essa relação é possível para professores, cujo desenvolvimento das funções intelectuais relacionadas à atividade laboral não estejam bloqueadas pela condição de alienação, sobretudo no que se refere à dissociação da atividade prática da atividade teórica combinada a sentidos desvinculados da significação social da docência. Ou seja, em uma condição de alienação, o motivo que impele o professor a sair de sua casa em direção ao seu trabalho não é substancialmente a criação de oportunidades de aprendizagem para seus alunos, mas apenas sua sobrevivência material humana.

Segundo, retomamos a conclusão já dita anteriormente sobre o modo geral de ação da professora Verônica, a de que a análise de suas mediações discursivas mostrou-nos que a sua capacidade criadora e imaginativa não está alienada de sua prática como docente, o que justifica o seu posicionamento no espaço de resistência à condição de alienação, subsequentemente, no campo em que se pressupõe a ausência de bloqueios à realização de seus motivos, por suposto, ao desenvolvimento das funções psicológicas relativas às funções laborais.

Seguimos adiante com a defesa de que a construção da atividade humana como práxis, bem como a ocorrência de aprendizagem docente e de desenvolvimento profissional passam necessariamente pela realização de motivos, uma vez que atividade e motivo são indissociáveis. Para quem é professor ou formador de professores não é difícil imaginar a plausibilidade de tal defesa, basta lembrar como nos sentimos ao final de uma aula ou de um encontro formativo, avaliados como bem sucedidos.

Para o professor, uma aula bem sucedida é aquela que o deixa satisfeito. Tal resposta, apesar de óbvia, deixa uma dúvida: quais indicadores apontam bons resultados? Cada professor constrói seus indicadores, pois a qualidade de determinado resultado depende da lente de quem o olha e o analisa. Neste trabalho, por exemplo, a realização dos motivos da professora Verônica, ou seja, o alcance de seus objetivos mediados por suas mediações discursivas está submetido a indicadores por nós construídos.

Aos nossos olhos, nas aulas da professora Verônica, os resultados se manifestam na ressonância do movimento dialógico discursivo espelhado nas diferentes enunciações. No processo de análise, assistimos diferentes oportunidades de aprendizagem criadas para as 
crianças, cujo papel de tutora, desempenhado pela professora, possibilitou o desencadeamento de um processo de apropriação de significados por elas, por meio do estabelecimento de relações, imaginação, criação, leituras, escritas, e outros modos de medição.

Satisfazer sua necessidade de ensinar de modo a presenciar o avanço de seus alunos em Ciências e nas demais áreas, não é senão realizar o motivo que a impele a continuar como docente, que a impele a construir sentidos coerentes com a construção da docência como atividade, por conseguinte, condizentes com o seu processo de desenvolvimento profissional.

Outro aspecto de suma importância para a tese aqui em construção é a ideia de que a realização do motivo/objetivo reafirma o potencial de reversibilidade do signo mediacional sobre a plasticidade do cérebro da professora. A relação mediada estabelecida com seus alunos a fim de transformá-los tem mão dupla, age em direção ao processo de aprendizagem de seus alunos, e retorna, em direção à sua formação, como docente.

Entretanto, há objetivos que não são facilmente realizáveis em determinado contexto ou requerem o adiamento de sua realização, como é o caso das dúvidas e lacunas que surgem no movimento dialógico discursivo em uma aula, as quais podem soar como necessidades de formação docente, que, para serem resolvidas, exigem que sejam revertidas em situações de aprendizagem da docência. Ao longo da análise identificamos algumas, as quais são reiteradas a seguir.

\subsubsection{Necessidades formativas e situações de aprendizagem da docência}

O nosso olhar sobre a sala de aula nos fez ver também o aflorar de necessidades formativas docentes. Em nossa compreensão, necessidade formativa pode se caracterizar como lacunas presenciadas nas mediações docentes e/ou como ausência de elementos teóricos condizentes com a base epistemológica de determinada área e de elementos metodológicos supostamente necessários à prática do ensino da respectiva área. As necessidades formativas são evidenciadas no processo de dialogia, a partir de enunciações dos alunos, as quais podem ou não gerar motivos de aprendizagem, a depender da consciência da professora sobre essas necessidades. A tomada de consciência sobre determinada necessidade a torna motivo e problema de aprendizagem da docência, com capacidade de impeli-la à busca de soluções.

Na primeira aula, cuja base de discussão foi o texto sobre o submarino, as perguntas das crianças foram o estopim das dúvidas da professora sobre o assunto em estudo, as quais se tornaram necessidades e motivos de pesquisas. A pesquisa realizada pela professora para 
preparar a aula seguinte, embora não a tenhamos presenciado, configurou-se como uma situação de aprendizagem, cuja voz mais experiente pode ter sido um livro ou um site ou mesmo os textos científicos contidos na Sequência Didática elaborada por pesquisadores participantes da parceria da escola com a universidade. Presenciamos apenas o resultado dessa pesquisa no conteúdo das mediações discursivas docentes observadas na aula seguinte, o que para nós foi suficiente para concluir sobre a situação de aprendizagem instaurada, bem como pela satisfação da necessidade que a gerou.

A segunda aula, estruturada como uma roda de conversa sobre a resolução do desafio do barquinho, também é considerada como uma situação de aprendizagem, na qual o caráter reprodutivo delegado às mediações discursivas foi abordado como uma necessidade formativa, surgida no próprio espaço aberto pela contradição imanente à sua existência. Vozes virtuais advindas de encontros formativos se posicionaram, no curso do movimento dialógico discursivo, como vozes parceiras colaborando com o compartilhamento de compreensões pela professora e, por suposto, com o seu desenvolvimento profissional.

$\mathrm{Na}$ terceira aula, logo no primeiro episódio, constatamos uma necessidade formativa convertida em uma situação de aprendizagem, motivada por uma enunciação de um aluno, cujo conteúdo - fossilização em âmbar dos mosquitos que sugavam dinossauros - era desconhecido pela professora. Tal necessidade foi resolvida pela professora em suas buscas pela internet ou livros, comentada por ela às suas parceiras de trabalho na escola. A última necessidade apenas notada via análise, a respeito da concepção de Evolução das Espécies transparecida no movimento dialógico discursivo do segundo episódio, não foi reconhecida pela professora como necessidade, portanto não se converteu em situação de aprendizagem.

Tais situações de aprendizagem trazem em si o seu potencial de incidência sobre a Zona de Desenvolvimento Proximal da professora por caracterizar-se como situação coletiva e colaborativa, iniciada na sala de aula entre a professora e seus alunos e concluída com a satisfação das necessidades que a geraram e, certamente, com o acréscimo de elementos teóricos ao processo de desenvolvimento profissional da professora, no caso à formação do seu pensamento teórico.

Em suma, o movimento de ensino e aprendizagem inerente às relações dialógicas da sala de aula pode nos dizer muito sobre o fazer docente, sobre motivos/objetivos realizados ou não, sentidos em construção, necessidades de formação no plano teórico e metodológico, bem como elementos em processo de apropriação e domínio pela professora. 
Esses elementos em processo de apropriação e domínio, entendidos como funções psíquicas relativas à atividade laboral em formação, são aqui categorizados como indícios de desenvolvimento profissional.

\subsubsection{Indícios de desenvolvimento profissional}

Os indícios de desenvolvimento profissional docente são constatados no movimento dialógico discursivo, espelhados na relação de correspondência entre sentido/motivo/objetivo docente e resultados imanentes às enunciações das crianças. De tal modo, completamente relacionados aos processos sociais vivenciados pelo professor no dia a dia de seu trabalho.

Criatividade e imaginação científica, capacidade de síntese, construção do padrão temático por meio da introdução da linguagem científica e compartilhamento de compreensões e informações; a busca pela satisfação das necessidades formativas; criação e imaginação no planejamento de ações, aparente nas ações propostas para motivar a leitura e nas ações de elaboração de atividades de aprendizagem, são elementos que põem em evidência a formação do pensamento teórico da professora, importante função psicológica que, a nosso ver, vai além da apropriação e domínio sobre instrumentos metodológicos, pois abrange também a apropriação sobre significados científicos próprios das áreas de ensino, no caso em estudo, da área de Ciências Naturais. Reafirmamos que houve avanços no processo de formação desse pensamento, ainda que tenhamos constatado elementos do pensamento empírico no conteúdo de suas mediações na conversação sobre a flutuação de corpos na aula 02. Não esquecemos de que o desenvolvimento profissional da professora é visto aqui como prospectivo, cujos avanços e/ou recuos estão relacionados à qualidade das situações desencadeadas de sua atividade.

Variados elementos tomados para compor o modo geral de ação da professora podem

ser vistos como indícios de funções psicológicas em formação, como sua identidade e personalidade laboral: agilidade em ouvir e interpretar as enunciações dos alunos; relacionar o conteúdo de uma enunciação com outra e de transformar as enunciações dos alunos em signos mediadores; fluidez e segurança nos atos de ensinar; avaliar e tomar decisões diante de necessidades e imprevistos; desenvoltura para se expressar oralmente, de modo que as crianças a entendam; dirigir e centrar a atenção dos alunos; sintonizar seus objetivos e motivos com os motivos das crianças; ou ainda, o modo como estabelece pactos de silêncio e de comunicação. 
Presenciamos também elementos significativos a respeito de processos de apropriação e domínio sobre determinados modos de mediação, com a persistência em buscar levar seus alunos a estabelecer relações, ainda que com dificuldades. De fato, tal modo de mediação aparece e reaparece nas três aulas analisadas, sendo adotado com mais segurança e com melhores resultados na última, o que mostra o entrelaçamento de tais processos, aqui tomados como indícios de desenvolvimento da professora.

Outro aspecto que merece ser considerado como importante indício de desenvolvimento é a atitude da professora ao assumir perante seus alunos sua insuficiência de conhecimentos acerca do assunto em discussão. Nessa mesma linha de raciocínio interpretamos seu modo de conceber a criança no processo de aprendizagem, como um sujeito capaz de produzir conhecimentos. A prova de tal concepção é vista em seu ato de partilhar a posse da responsabilidade pela busca de conhecimentos e de superação de dúvidas oriundas de perguntas proferidas pelas crianças. Tais concepções abrem espaços tanto para a superação das necessidades formativas como para promover atividades conjuntas, nas quais professora e alunos se inserem como sujeitos em aprendizagem, com possibilidade de um atuar sobre a ZDP de outro, de um possibilitar o desenvolvimento do outro. Promover atividades conjuntas entre ela e seus alunos é, sem dúvida, um forte indício de desenvolvimento profissional. 


\section{Capítulo 6. Conclusões e considerações finais}

"Se podes olhar, vê. Se podes ver, repara".

José Saramago

O motivo que nos impeliu a realizar esta pesquisa originou-se de necessidades gestadas no dia a da escola, ao participarmos de um processo formativo em ciências junto a professoras dos anos iniciais em uma escola pública. Fomos mobilizados pela necessidade de estudar com mais profundidade a formação de professores e a relação dialética que há entre aprender a ensinar e a prática dessa aprendizagem como docente em sala de aula.

Sem perder de vista a dimensão social, cultural e política da educação, fomos impulsionados a investigar o microcosmo da sala de aula, a buscar nas relações mediadas que regem o movimento dialógico discursivo estabelecido entre professora e alunos, subsídios que nos possibilitassem discutir sobre modos como o professor aprende e se desenvolve no âmago de sua atividade pedagógica realizada na sala de aula.

Entretanto, ao tomarmos consciência sobre a complexidade do fenômeno a ser estudado, passamos a buscar um aporte teórico que correspondesse às necessidades a nós apresentadas, motivo pelo qual optamos pela perspectiva histórico-cultural.

Nesse aporte teórico encontramos subsídios que nos levaram a presumir o trabalho docente como mediador da apropriação de significados tanto pelos alunos como pelo professor. O professor, ao buscar transformar qualitativamente seus alunos, cria condições para sua autotransformação - ideia básica expressa pela dimensão ontológica do trabalho encontrada nos estudos marxistas e no conceito de atividade oriunda de tal dimensão, aprofundado nos estudos vigotskianos e, por fim, estabelecido como uma teoria por Leontiev.

A autotransformação docente condizente com o desenvolvimento profissional é analisada e interpretada a partir de princípios da âmbito da Teoria da Atividade, como um processo gestado por necessidades formativas decorrentes da docência construída no sentido da práxis pedagógica - universalidade, na qual as relações de correspondência entre motivo/objetivo e sentido/significação social se estabelecem em seu grau máximo no plano da consciência do sujeito.

Entretanto, essas relações podem não ser estabelecidas: o motivo que mobiliza o sujeito pode não coincidir com o objetivo da atividade na qual ele está inserido, e os seus sentidos podem não ser correspondentes ao significado de tal atividade. Nesse caso, 
estaríamos diante de um quadro de alienação, contrário ao que almejamos como práxis. Esse sujeito estaria destituído de signos teóricos e instrumentos imprescindíveis à sua realização laboral.

Ao tomarmos consciência dos tantos fatores que impactam a profissão docente no Brasil, temos a sensação de que a plena superação da alienação é algo inatingível na atual sociedade, o que nos leva a concordar com Duarte (2004), cujo ponto de vista defende que a plenitude da humanização apenas é possível com o advento de uma nova ordem social.

Entretanto, não temos dúvida de que a construção dessa nova ordem social não apenas orienta nossas ações como ser humano em atividade, mas também se realiza gradativamente a cada ação. Felizmente, a inquietude da personalidade humana nos conduz a atuar nas próprias frestas abertas pela relação dialética estabelecida entre esses dois campos: necessidades emergem das relações de contradição que regem a complexidade do cotidiano escolar, as quais podem se objetivar na criação de espaços coletivos formados por sujeitos, cujas ações resistem à condição de alienação. Gesta-se uma tensão interna entre os impactos subjetivos e objetivos que afetam negativamente o trabalho docente e a necessidade de realização da docência, de modo a cumprir sua função social. Essa tensão interna pode, por um lado, afetar o motivo docente e até levar a perda de sentidos e, por outro, gerar mudanças favoráveis à reafirmação e/ou à construção de novos sentidos pelo professor. Esses novos sentidos, uma vez estabelecidos no plano de sua consciência, podem potencializar sua resistência em relação ao que lhe aliena ou afasta do seu trabalho como desencadeador de seu desenvolvimento. Esse núcleo de resistência, forjado pelos sujeitos em atuação, tem em si objetivada a relação dialética entre a alienação e a atividade humana ou práxis.

$\mathrm{Na}$ dimensão da escola, como um contexto social, cultural e político, existem sujeitos com diferenciados níveis de consciência em relação à sua posição nesse plano que intersecta a condição de realização da docência como atividade e a condição de alienação. Verônica, professora analisada no corpo desta tese, é um desses sujeitos, portanto tão objetivamente impactada quanto os demais professores. Entretanto, aqui defendemos a sua condição de professora em desenvolvimento profissional, cujos motivos e sentidos falam de seu grau de consciência quanto à necessidade de se formar humano na realização de sua docência.

Não nos referimos à plenitude ou condição optimal da práxis para que consideremos o sujeito em desenvolvimento, pois se assim o fizéssemos estaríamos ignorando a relação dialética acima discutida. Contudo, consideramos a sua inserção na abrangência do núcleo de 
resistência à alienação, isto é, no plano da contínua atribuição de sentidos favoráveis à construção da atividade docente como práxis. Essa inserção é, aqui, considerada como condição para a fluência da formação da consciência, da personalidade e das demais funções psíquicas relativas à atividade laboral. A práxis, por assim dizer, se inclui no plano da universalidade, concebida como o “(...) desenvolvimento máximo alcançado pelo gênero humano" (Asbahr, 2011, p. 184), para a qual direcionamos nossos motivos e objetivos, ao defendermos a educação como atividade humanizadora, cujo objeto é a transformação humana.

Assim, justificamos a construção da narrativa sobre a história de vida formativa e profissional da professora Verônica, como uma forma de nos aproximarmos de motivos que a impelem a ensinar e de alguns dos sentidos atribuídos por ela ao seu trabalho como docente. Com base em Leontiev (1983), reiteramos a importância de conhecer o seu motivo para que que se possa concluir sobre o seu grau de inserção na atividade na qual ela está inserida.

Os primeiros elementos, fornecidos por essa narrativa, foram importantes para que começássemos a compor o seu modo geral de ação e para que nos preparássemos para iniciar o processo de análise sobre a relação entre esse modo geral de ação e seu desenvolvimento profissional. Além de estabelecermos contato com o seu motivo e alguns de seus sentidos, o processo de composição da narrativa de sua história nos propiciou a historicidade de seu desenvolvimento humano e também profissional, o que nos fez vê-lo como um objeto em processo, de modo retrospectivo e prospectivo.

No entanto, a apreensão da essência do fenômeno investigado só foi possível via mediação discursiva docente, tomada como unidade de análise, por integrar linguagem e ação como signos/instrumentos interpostos pelo professor nas relações estabelecidas entre ele e o processo de aprendizagem de seus alunos. Por suposto, a mediação discursiva docente guarda elementos essenciais da totalidade do fenômeno estudado, constituindo-se como a chave que abriu as portas necessárias para que visualizássemos o movimento dialógico discursivo e dele abstraíssemos respostas para o problema que nos orientou nesta investigação: o que a mediação discursiva docente pode mostrar sobre o trabalho docente e desenvolvimento profissional de professores que ensinam ciências nos anos iniciais sob orientação investigativa.

De fato, essa unidade de análise mostrou-nos significativos elementos que nos permitiram relacionar trabalho docente e desenvolvimento profissional, exatamente o que 
buscávamos discutir sobre como a professora pode aprender e se desenvolver, ao mediar o processo de aprendizagem de seus alunos em ciências.

Sentidos atribuídos por ela a aspectos importantes de sua docência são os primeiros destaques manifestos: a importância dada ao trabalho coletivo na escola, em especial, à parceria com suas colegas de trabalho; valorização da busca de recursos e de outros modos de mediação para que seu objetivo de ensinar se realizasse; a reafirmação de que os pais incentivam e contribuem com a educação dos filhos na escola; a constatação de que a linguagem científica não é a única a fazer parte dos diálogos e estudos em sala de aula; sua predisposição ao auto estudo e à pesquisa como fonte para resolver seus problemas de ensino; o modo que concebe os alunos, como sendo sujeitos capazes de aprender e de produzir conhecimentos; prestigio dado à voz da criança, com destaque para o lugar que ela ocupa na comunicação em sala de aula; o modo como concebe o papel do professor no processo de ensino, como sendo aquele que não é o dono do conhecimento e que pode assumir dúvidas perante seus alunos.

A qualidade desses sentidos reforçou a nossa ideia sobre sua condição de sujeito que resiste ao plano da alienação e que busca se aproximar do conhecimento e dos demais instrumentos e signos inerentes à sua necessidade de ensinar de modo a realizar o seu motivo/objetivo - criar oportunidades de aprendizagem para seus alunos. Em tal plano, o seu desenvolvimento profissional pode fluir com factibilidade.

A mediação discursiva também nos mostra que é possível visualizar na amplitude das relações mediadas da sala de aula a relação estabelecida entre motivos e objetivos. A essência de cada mediação é o motivo docente aparente no objetivo realizado. Visualizamos também o significado da realização desse motivo/objetivo para o desenvolvimento profissional docente. Realizar o motivo/objetivo, inerente à necessidade de criar oportunidades de aprendizagem para seus alunos, pode provocar na consciência docente a construção de novos sentidos, o que, por sua vez, pode ter reforçado a relação de correspondência que há entre os sentidos atribuídos à sua atividade pedagógica e a significação social da docência - condição, sem a qual não podemos falar em construção da atividade como práxis e nem podemos pautar a fluência no processo de desenvolvimento profissional. Por conseguinte, defendemos que a construção paulatina da docência como práxis, bem como a profícua relação entre aprendizagem e desenvolvimento docente, passam necessariamente pela realização dos objetivos e motivos. 
No caso de nossa professora, a realização de seus objetivos/motivos, imanentes às suas mediações discursivas, espelha a satisfação de sua necessidade de ensinar de modo que seus alunos se apropriem de significados. As enunciações das crianças, os signos interpostos por elas, bem como o seu grau de envolvimento com as proposições de cada aula, nos falam da satisfação dessa necessidade docente, isto é, do processo de criação e imaginação e contextos mentais criados, das compreensões compartilhadas, entre outros objetivos alcançados.

Compõe o corpo de nossas conclusões a interpretação de que a realização dos motivos e objetivos pela professora reafirma o potencial de reversibilidade do signo/instrumento mediacional sobre a sua formação como docente. Tal inferência nos faz reforçar a ideia preconizada como hipótese no inicio da pesquisa e agora defendida como tese: os signos interpostos para mediar o processo de aprendizagem de seus alunos em ciências, para ensiná-los a falar ciências, para deixar marcas em seu desenvolvimento cultural e intelectual, podem reverter ou retornar como signos mediadores de sua autotransformação, podem também deixar marcas em sua mente, em síntese, também podem também mediar o seu desenvolvimento humano e profissional. Aqui está o principal elo aqui estabelecido entre o ensinar e o aprender a ensinar.

Alguns desses signos adotados pela professora foram pontuados entre os resultados, como o deslocamento mental, espacial e temporal estabelecido via imaginação e criação; relações estabelecidas entre significados distintos apropriados em contextos diferentes; comparações entre semelhanças possibilitadas pelo pensamento analógico; compartilhamento de compreensões e informações; processo de elaboração de relações causais, entre outros.

As mediações discursivas também nos informam sobre a relação aprendizagem e desenvolvimento, analisada sob enfoque vigotskiano, cuja orientação nos leva a argumentar em defesa do suposto desenvolvimento ocorrido a partir das situações de aprendizagem emergidas do próprio movimento dialógico e das lacunas observadas no fluxo discursivo. Cada aula analisada, constituída como uma comunidade multivocal, foi configurada como uma situação de aprendizagem da docência, ainda que o parceiro mais experiente não estivesse fisicamente presente. Afinal, é possível resolver problemas em colaboração com vozes guardadas em nossa memória (Vigotski, 1987). A professora Verônica contou com a colaboração de vozes parceiras advindas de experiências formativas e profissionais vivenciadas no presente e no passado; contou com colaborações advindas do próprio aluno, contidas no livro-texto do aluno e/ou buscadas em outros livros, sites, entre outras fontes de 
pesquisa. O certo é que, presentes fisicamente ou não, parceiros e parceiras da professora fizeram com que situações por ela vividas com seus alunos fossem convertidas em situações de aprendizagem, com potenciais de incidência sobre sua Zona de Desenvolvimento Proximal, subsequentemente, com chances de promover o desenvolvimento de supostas funções psicológicas relativas à atividade laboral, em propenso amadurecimento.

Entre essas funções em propenso desenvolvimento situamos aquelas relativas à formação da consciência, da personalidade laboral e do pensamento teórico, com possibilidades de terem avanços em seu grau de amadurecimento a cada ação realizada no corpo de sua atividade nos diferentes planos de sua docência: ao imaginar e criar uma atividade investigativa de aprendizagem; ao selecionar os instrumentos adequados à aprendizagem de seus alunos; ao por em prática e realizar seus planos e objetivos junto aos seus alunos; ao tomar decisões rápidas sobre qual modo de mediação adotar em situações não previstas ou sobre qual voz contida em sua memória deve ser escutada naquele momento; ao realizar sínteses, compartilhar compreensões e se deslocar no tempo e no espaço por meio da imaginação e criação, junto aos seus alunos; ao reconhecer sua insuficiência de conteúdos consigo mesmo ou diante de seus alunos e/ou parceiras de trabalho; ao buscar fontes materiais ou pessoas para dirimir suas dúvidas e replanejar suas aulas; ao compartilhar seus estudos e reflexões no grupo coletivo da escola e da universidade; ao escutar e refletir sobre opiniões e orientações no grupo da escola e da universidade; em suma, ao realizar qualquer ação, cujo motivo/objetivo esteja correlacionado ao objetivo que orienta a sua atividade docente.

Essas ações mostram marcas ou indícios de desenvolvimento dessas funções laborais, entendidas como funções psicológicas superiores, que, como tal, estão em contínua formação no plano interno da mente da professora, oriundas de relações sociais estabelecidas no âmbito de sua docência (Vigotski, 2000). A partir dos resultados obtidos com a análise das três aulas, defendemos: há indícios de desenvolvimento no processo de apropriação e domínio sobre determinados modos de mediação, por sua vez, indicadores de avanços em sua personalidade laboral; sua consciência se forma a cada sentido atribuído; seu pensamento teórico avança em relação ao seu processo de apropriação sobre significados próprios da área de ciências naturais e sobre conhecimentos de cunho psicopedagógico.

Enfim, o nosso olhar sobre a sala de aula, mediatizado pelas mediações discursivas da professora, nos responde que a relação aprendizagem e desenvolvimento profissional docente no processo de ensino está diretamente relacionada com o conteúdo e com o caráter de mutabilidade dos motivos e sentidos do professor: motivo e objetivo coincidentes, bem 
como, sentidos atribuído à atividade pedagógica correspondentes à significação social da docência são condições que aumentam o potencial de aprendizagem da atividade, na qual o sujeito está inserido. Esse potencial de aprendizagem, por sua vez, está relacionado ao potencial de incidência da atividade sobre sua Zona de Desenvolvimento Proximal, o que resulta em mais possibilidades de amadurecimento de funções psicológicas relativas ao seu exercício laboral.

Não é demais repetir que essas relações não são lineares e nem estão prontamente dadas como estabelecidas. Referimo-nos a um processo de contínuos avanços e retrocessos, condicionados a impactos objetivos e subjetivos, de cunho político, social, cultural, afetivo e fisiológico. Reiteramos que essas relações também dependem das gradativas tomadas de consciência pelo professor do lugar, em que ele próprio, o aluno, a atividade docente, bem como a instituição escolar ocupam na atual sociedade. Esse papel não é senão uma construção cultural e ideológica, portanto, completamente imbricado aos seus motivos e sentidos.

Todavia, vale lembrar que a professora Verônica não resiste aos impactos alienantes de sua docência isolada em sua sala de aula e nem essa resistência se restringe à sua atividade conjunta com seus alunos. Suas ações inserem-se na particularidade de um sistema coletivo de atividade, tal como preconiza Engestrom (1999) e Daniels (2003), o qual espelha o modo como o ensino de ciências nos anos iniciais é organizado em tal contexto escolar. Comunidades vocais se inter-relacionam com vozes que ressoam e influenciam os conteúdos de suas mediações discursivas, colaborando com a realização de seu motivo/objetivo.

Nesse sentido, passamos a enxergar a professora aqui estudada como sujeito, a um só tempo, coletivo e individual. O conteúdo de suas mediações discursivas extrapola sua singularidade como docente e abrange singularidades contempladas no contexto particularizado, no caso o sistema coletivo de atividade. Necessidades reveladas pela professora Verônica pertencem, em determinada proporção, às demais professoras desse sistema. No mesmo raciocínio, situações que afetam a ZDP da professora, incidem sobre a ZDP individual dos demais sujeitos e sobre a ZDP coletiva e vice-versa; sentidos atribuídos pela professora representam sentidos coletivos, assim como objetivos realizados espelham alcances coletivos.

Portanto, o conceito de desenvolvimento profissional docente construído neste estudo amplia-se para além do indivíduo isolado em suas próprias intenções e abrange o processo contínuo de revitalização de motivos e de atribuição de sentidos individuais e coletivos, por conseguinte, situa-se no plano da formação gradativa da consciência do sujeito 
individual e coletivo, tanto em relação à condição social e política imposta ao trabalho docente atualmente, quanto à sua própria condição diante de sua necessidade de desenvolvimento contínuo. Inserir-se nesse contínuo processo significa ampliar as possibilidades de superar a si mesmo, seja na amplitude de suas singularidades, seja na contínua busca pela universalidade humana.

A ampliação do conceito de desenvolvimento profissional aqui considerada pode ser uma das contribuições desta pesquisa às discussões sobre formação de professores. Alertamos quanto à importância de se prestar atenção nos motivos e sentidos atribuídos à atividade pedagógica pelos docentes participantes dos processos formativos. Levar professores a tomar consciência sobre o sentido coletivo atribuído pela sociedade à educação e sobre os seus próprios sentidos pode significar o começo de uma longa caminhada em direção à necessária inserção de qualquer processo formativo em uma dimensão política e social, bem como da abertura de espaços para se trabalhar com a relação entre o singular e a possibilidade de alcance do universal. Além do mais, vale lembrar que a atuação do professor em qualquer núcleo ou grupo de trabalho coletivo que resiste à condição de alienação, seja do sujeito individual ou coletivo, não prescinde desse grau de consciência.

Os resultados referentes aos modos de aprendizagem visualizados no movimento constituído na sala de aula possibilitam aos formadores de professores o contato com elementos essenciais que podem levar às reflexões sobre necessidades e possibilidades da docência nos anos iniciais. De um lado, mostramos a sala de aula em uma escola pública que, embora apresente determinadas peculiaridades, é uma escola que vivencia toda e qualquer dificuldade comum às demais da região, onde é situada. Nessa escola, nessa sala de aula emergem necessidades docentes e discentes autênticas. Por outro lado, mostramos a rede de apoio, interferências e influência no trabalho da professora Verônica, extensivo às demais professoras, representada no sistema coletivo de atividade.

Entre as comunidades vocais constituintes desse sistema, destacamos as duas experiências formativas, ambas centradas na escola, com privilégio de contínuos estudos coletivos com abordagens teóricas sobre significados pertinentes à área das Ciências Naturais, e ainda de estudos metodológicos com sugestões de como ensinar ciências nesse nível do ensino. Ainda que de modo contextual, foi possível apresentar esses dois processos formativos, suas respectivas intenções e limites diante de seus potenciais formativos. Visualizamos dois processos viabilizados por modelos de formação que, embora tenham 
apresentado objetivos aparentemente contraditórios, se complementaram em muitas das relações estabelecidas.

Ao focalizarmos de longe esse quadro formativo, dizemos que ambos os processos revitalizam a escola e contribuem com o desenvolvimento profissional de seus sujeitos. De um lado, os resultados relacionados à parceria aqui referenciada nos levam a reforçar a ideia de que parcerias escola/universidade podem favorecer a atribuição de sentidos para os sujeitos envolvidos, caso os acordos forem bem estabelecidos, com consciência de ambas as partes sobre limites e possiblidades sobre esses acordos. Não podemos esquecer que professores da universidade, assim como os da escola, são sujeitos em formação, cujos motivos e sentidos também requerem construção paulatina, de modo que estabeleçam relações de correspondência com o significado da docência, entendida como atividade social e humana ou como práxis. Afinal a docência universitária, a despeito de suas especificidades, ocupa um lugar na atual sociedade e também tem sofrido impactos do "fenômeno de precarização social do trabalho e da consequente alienação do trabalhador" (Lemos, 2011, p. 105). Portanto, parcerias escola/universidade podem se constituir em projetos necessários à contínua aprendizagem e a qualificadas produções para ambas as instituições.

Do outro lado, o processo formativo próprio da escola, gestado e posto em prática pelos próprios professores, se realiza como o principal núcleo de atuação e resistência, sobretudo porque persiste na busca contínua pela apropriação de instrumentos, com os quais se constrói dia a dia o ensino. Esses núcleos, quando constituídos no sentido da coletividade, não apenas avançam com seus próprios esforços coletivos, mas viabilizam parcerias entre instituições, atuam conjuntamente a elas, as favorecendo e sendo favorecidos. Desse modo, reforçamos o valor do trabalho coletivo, como instrumento mediador da realização do trabalho docente e mediatizador da aprendizagem e desenvolvimento profissional dos professores nele envolvidos.

\section{A pesquisa para a pesquisadora}

Falaremos agora na primeira pessoa, em nome da autora, no papel da pesquisadora e a da coordenadora da escola. Em ambos os papéis visualizo o meu desenvolvimento acadêmico e profissional, embora tenha dificuldades em distinguir um do outro, pelo fato de ambos se tratarem do meu desenvolvimento como ser humano. Embora eu me insira em duas 
atividades diferentes, em ambas sou movida pelo mesmo motivo - a busca incessante pela educação que humaniza, que forma e transforma em prol da universalidade humana. Formar professores e realizar pesquisas são atividades que fazem sentido para mim em correspondência à qualidade da educação que socialmente se almeja como significação.

A tese mostra essa quase inseparabilidade, em que uma atividade fundamenta a outra: sem o trabalho da escola, a trajetória empírica descrita na tese não existiria; sem o estudo sistematizado do aporte teórico escolhido, não seria possível compreender os fenômenos vivenciados na escola e nem torná-los objeto de pesquisa.

Entretanto, a tese resulta de um longo processo de estudos, discussões e tentativas de escrita. No início, era apenas um projeto com um contexto delimitado, uma linha teórica em processo de definição e um vago problema de pesquisa. Só depois de debruçar-me sobre o aporte teórico, conhecer com profundidade os dados empíricos e, concomitantemente, dialogar com parceiros de estudos, o fenômeno investigado foi tomando forma em minha mente. Ainda assim, o objeto de estudo só se tornou claro o bastante quando a teoria se tornou instrumento mediador da análise.

A tese é a síntese desse processo de apreensão teórica sobre o objeto de estudo, apenas possível porque finalmente o quadro do desenvolvimento profissional da professora Verônica abriu-se diante de mim e se tornou presente em minha consciência (Leontiev, 1978). Tê-lo em minha consciência, significou que, então, eu pude reparar nesse objeto e enxergá-lo para além do que os meus olhos viam. Essa reflexão advém da voz de José Saramago ressoada em minha memória: "Se podes olhar, vê. Se podes ver, repara".

Todavia, nem tudo foi visto, por conseguinte, nem reparado, pois nem tudo se tornou presente em minha consciência. No processo de realização deste trabalho, algumas inquietações foram tomando corpo e adiadas para discussões e investigações futuras. A crise do ensino de ciências ainda não foi vencida; a sala de aula nos anos iniciais ainda contempla problemas a serem tornados objetos de estudo; a docência ainda sofre impactos do fenômeno da alienação; a educação ainda não se substancia como humanizadora. Portanto, de minhas inquietações surgem novas indagações: como acompanhar e verificar mudanças no processo de atribuição de sentidos por professores ao longo de um determinado processo formativo? Quais fatores qualificam determinado processo formativo para que esse possa contribuir com a promoção de mudanças qualitativas no processo de atribuição de sentidos pelos professores? 
Isto é, a formação das funções psicológicas superiores do professor, sobretudo a formação de sua consciência, ainda se constitui para mim como um fator gerador de mudanças, ainda situada em minha mente como uma grande interrogação.

Essa indagação, representativa de muitas outras, mostra-se como um pergunta autêntica porque de fato não tenho sua resposta e pergunto porque quero sabê-la. Porque é autêntica, desnuda a minha condição humana de inacabamento e inconclusão, como também simboliza a minha busca interminável por formar-me humana, refletida na continua formação de minha consciência e personalidade.

Como diz Paulo Freire, “onde há vida há inacabamento”. Experimento-me assim, um ser incompleto e, talvez seja porque tenho consciência de minha incompletude que gesto em mim a necessidade de saber, como motivo que me impulsiona a continuamente fazer perguntas e buscar respostas. Pois, a pergunta um ato eminentemente humano, um ato que incita em nós humanos, a vontade de saber, a capacidade de nos assombrar diante do novo e de tornar o nosso assombro um caminho que nos leva ao próprio conhecimento e à solução de nossos "verdadeiros problemas essenciais e existenciais" (Freire e Faundez, 1985). 


\section{REFERÊNCIAS BIBLIOGRÁFICAS}

ABIB, M. L. V. S. Por que os objetos flutuam? Três versões de diálogos entre as explicações das crianças e as explicações científicas. In: Ensino de Ciências por investigação: condições para implementação em sala de aula. Carvalho, A. P. C. (org.). São Paulo: Cengage Learning, 2013.

AFONSO, A. M. Alfabetização Científica dos alunos e as ações do professor que corroboram com este processo. Dissertação de Mestrado, São Paulo: FEUSP, 2011.

ALARCÃO, I. Professores reflexivos em uma escola reflexiva. São Paulo: Cortez, 2005

ALMEIDA, M. I. O sindicato como estância formadora dos professores: novas contribuições ao desenvolvimento profissional. Tese de Doutorado, FEUSP, São Paulo 1999, p.20-53.

AGUIAR Jr., O. G. \& MORTIMER, E. F. Tomada de consciência de conflitos: análise da atividade discursiva em uma aula de ciências. In: Investigações em Ensino de Ciências V10(2), pp.179-207, 2005 Disponível em: http://www.if.ufrg.br/public/ensino

AgUIAR Jr., O. G. MENDONÇA, D. H., SILVA, N. S.. Análise do discurso em uma sala de aula de ciências: a postura do professor e a participação dos estudantes. In: Anais do VI ENPEC, 2007.

AGUIAR, Jr., O. G. ; MORTIMER, F. E.; SCOTT, P. H As perguntas dos estudantes e seus desdobramentos no discurso da sala de aula de ciências. In: $X$ Encontro de Pesquisa em Ensino de Física, 2006, Londrina. Anais do X EPEF. v. 1 (cd-rom).

ANDRADE, I. B. MARTINS, I. Discursos de professores de ciências sobre leitura. In: Investigações em Ensino de Ciências. V 11 (2), PP. 121-151, 2006.

APPLETON, K.; KINDT, L. Why teach prymary Science? Influences on beginning teacher's pratices. In: International jornal of Science Education, v. 14, n. 5, p. 291-503, 1992.

ARAÚJO, E. S. Da formação e do formar-se: a atividade de aprendizagem docente em uma escola pública. Tese de Doutorado, São Paulo: FEUSP, 2003.

ASBAHR, F da S. F. Sentido pessoal e projeto político-pedagógico: análise da atividade pedagógica a partir da psicologia histórico-cultural. Dissertação de Mestrado. São Paulo: Instituto de Psicologia da USP, 2005.

, "Por que aprender isso, professora?" Sentido pessoal e atividade de estudo na

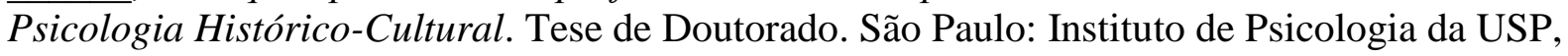
2011.

AZEVEDO, M. N. Ensinar ciências e pesquisa-ação: saberes docentes em elaboração. Jundiaí: Paco Editorial, 2013.

- Pesquisa-ação e atividades investigativas na aprendizagem da docência em

Ciências. Dissertação de Mestrado, São Paulo: FEUSP, 2008. 
; ABIB, M. L. V. S. Arco-íris em foco - a linguagem como mediação da aprendizagem no primeiro ano de escolarização. In: Anais do XII Encontro de Pesquisa em Ensino de Física, Águas de Lindóia - SP, 2010. Disponível em http://www.sbfisica.org.br/ epef/xii/

; FONTE, A. P. C. \& NAVARRO. S. G. Contribuições da parceria para a escola sob o ponto de vista das professoras envolvidas. In: Painel Parceria Universidade/Escola Pública: Contribuições e possibilidades na formação docente a partir de um projeto de alfabetização cientifica. In: Anais do XV ENDIPE, Belo Horizonte, UFMG, 2010.

;Parceria escola pública/universidade: relação aprendizagem docente e desenvolvimento profissional em ciências. In: XVI ENDIPE, Campinas-SP, UNICAMP, 2012.

AZZI, S. Trabalho docente: autonomia didática e construção do saber pedagógico. In: PIMENTA, S.G. (org). Saberes Pedagógicos e atividade docente. São Paulo: Cortez, 2005.

BAKHTIN, M. Estética da criação verbal. São Paulo: Martins Fontes, 1997.

BAKHTIN, M. (VOLOSHÍNOV). Marxismo e filosofia da linguagem. São Paulo: Hucitec, 2010.

BARBOZA, D. \& ZANELLA, A. V. Integrando análise de conteúdo e análise microgenética em pesquisas de campo psi: a constituição do sujeito em foco. In: PSICO, Porto Alegre, PUCRS, v. 36, n. 2, pp. 189-196, maio/ago. 2005.

BARros, J. P. P., PAUla, L. R. C., PASCuAl, J. G., COlAÇO, V. F. R., XIMENES, V. M., O conceito de "sentido"em VYGOSTSKY: considerações e epistemológicas e suas implicações para a investigação psicológica. In: Psicologia e Sociedade, 21 (2): 174-181, 2009.

BASSO, I. S. Significado e sentido do trabalho docente. In: Caderno CEDES, vol. 19 n. 44 Apr. 1998.

BERNARDES, M. E. M. Mediações simbólicas na atividade pedagógica: contribuições da Teoria Histórico-Cultural para o ensino e a Aprendizagem. Curitiba, PR: CRV, 2012.

BERNAL, B. V.; JIMÉNEZ-PÉREZ, R.; JIMÉNEZ, V. M. ? Como podemos llevar a cabo una investigación-acción para mejorar a la pratica en el aula de ciências? In. Investigações em Ensino de Ciências - V (131), PP. 45-64, 2008.

BERNIER, J. P. L'approche des pratiques langagières scolaires à travers la notion de « communauté discursive »: un apport à la didactique comparée? In: Revue française de pédagogie, Volume 141, 2002. pp. 77-88.

BEZERRA, M. H. B. Formação do Leitor: a escola cumpre a tarefa? Tese de doutorado, PUC-SP, 2009.

\& SOUZA, S. B. Aprender ciências: um meio para superar dificuldades de aprendizagem? In: Painel Parceria Universidade/Escola Pública: Contribuições $e$ possibilidades na formação docente a partir de um projeto de alfabetização cientifica. In: Anais do XV ENDIPE, Belo Horizonte, UFMG, 2010.

BOZELLI, F. C. Analogias e Metáforas no Ensino de Física: O Discurso do Professor e o Discurso do Aluno. Bauru, 2005, 234f: Dissertação (Mestrado). Programa de Pós-Graduação 
em Educação para a Ciência, Faculdade de Ciências, Universidade Estadual Paulista.

\& NARDI, R. Interações discursivas e o uso de analogias no ensino de física. In:

Investigações em Ensino de Ciências - V17(1), pp. 81-107, 2012.

BRAGA, E. S. A constituição social do desenvolvimento. In: Revista História da Pedagogia, vol. 2. Coleção Biblioteca do Professor. São Paulo, Editora Segmento, 2010.

BRICCIA, V.; CARVALHO, A. M. P. Competências docentes em um projeto de parceria universidade escola visando a alfabetização científica. In: Painel Parceria Universidade/Escola Pública: Contribuições e possibilidades na formação docente a partir de um projeto de alfabetização científica. In: Anais do XV ENDIPE, Belo Horizonte, UFMG, 2010.

; Competências docentes em um projeto de inovação para a Educação Científica. Tese doutorado. São Paulo: FEUSP, 2012.

CALLIL, M. R. S. Formar e formar-se no berçário: um projeto de desenvolvimento profissional no contexto de um centro de educação infantil. Dissertação de Mestrado. São Paulo, FEUSP, 2010.

CANDELA, A. Ciência en el aula: los alumnos entre la argumentación y el discurso. México: Paidós, 1999.

CAPECCHI, M. C. V. M.; CARVALHO, A. M. P.; SILVA, D. Argumentação dos alunos e o discurso do professor em uma aula de física. In: Revista Ensaio, v.2, n.2, p.189-208, 2000.

CARVALH0, A. M. P. As condições de diálogo entre professor e formador para um ensino que promova a enculturação científica dos alunos. In: DALBEN, A.; DINIZ, J.; LEAL, L.; SANTOS, L (orgs. da coleção). Convergências e tensões no campo da formação e do trabalho docente. Belo Horizonte: Autêntica, 2010 (Coleção Didática e Prática de Ensino XV ENDIPE).

Uma metodologia de pesquisa para estudar os processos de ensino e aprendizagem em sala de aula,. In: SANTOS, F.M.T. e GRECA, I.M. Pesquisa em ensino de Ciências no Brasil e suas metodologias, Ijuí: Editora Unijuí, 2006.

CLARK, A. Magic words: how language augments human computation. In: in P. Carruthers and J. Boucher (Eds) Language and Thought: Interdisciplinary Themes (Cambridge University Press: Cambridge, 1998) P.162- 183.

CEDRO, W. L. O motivo e a atividade de aprendizagem do professor de Matemática: uma perspectiva histórico-cultural, tese de doutorado. São Paulo: FEUSP, 2008

CERATI, T. M. \& LAZARINI, R. A. M. A pesquisa-ação em educação ambiental: uma experiência no entorno de uma unidade de conservação urbana. In. Ciência \& Educação, v. 15, n. 2, p. 383-392, 2009.

COLE, M. Cultural psychologya: A once and future discipline. Cambridge, MA, Haward University, Press, 1996. 
Colaço, V. F. R.; Pereira, E.; Neto, F. E. P. ; CHAVES, H. V.; SÁ, T. S. Estratégias de mediação em situação de interação entre crianças em sala de aula. In: Estudos de Psicologia, 2007, 12(1), 47-56.

COSTA, M. V. Um olhar sobre a problemática do trabalho docente. In: Trabalho docente e profissionalismo. Porto Alegre: Ed. Sulina, 1996 (p. 83-123).

CRUZ, M. N. Imaginação, conhecimento e linguagem: uma análise de suas relações numa perspectiva histórico-cultural do desenvolvimento humano. Tese de doutorado. Campinas SP: Faculdade de Educação da Unicamp, 2002.

CUNHA, M. I. Profissionalização docente: contradições e perspectivas. In: VEIGA, I. P. A. \& CUNHA, M. I. (orgs). Desmitificação da profissionalização do magistério. Campinas: Papirus, 1999.

DANIELS, Harry (org. ). Vygotsky em foco: pressupostos e desdobramentos. Campinas, SP: Papirus, 6 a edição, 2003.

DELIZOICOV, D.; ANGOTTI, J. P. Metodologia do ensino de ciências. São Paulo: Cortez, 1990.

DIAS, Marisa da Silva \& MANZONI, Rosa Maria. Pensamento empírico e teórico no ensino da matemática e da língua materna. In: V Encontro Brasileiro de Educação e Marxismo, Educação e Emancipação Humana 11, 12, 13 E 14 de abril de 2011 - UFSC - Florianópolis $\mathrm{SC}$ - Brasil

DIONNE, L. Apprendre à lire, à ecrire et à parler de sciences: un modele pour guider la croissance dúne communauté d'apprenditissage didactique In: Éducation francophone en milieu minoritaaíre, Vol. 2, numero 1, 2007, Ottawa - Canadá.

DUARTE, M. da C. Analogias na educação em ciências contributos e desafios. In: Investigações em Ensino de Ciências - V10(1), pp. 7-29, 2005

DUARTE, N. O debate contemporâneo das teorias pedagógicas. In: MARTINS, L. M. \& DUARTE, N. (orgs). Formação de professores: Limites contemporâneos e alternativas necessárias. São Paulo: Cultura Acadêmica, 2010.

Formação do Individuo, consciência e alienação: o ser humano na psicologia de A.

N. Leontiev. In: Cad. Cedes, Campinas, vol 24, n. 62, p. 44-63, abril 2004.

A anatomia do homem é a chave da anatomia do macaco: A dialética em Vigotski e em Marx e a questão do saber objetivo na educação escolar. In: Educação e Sociedade, ano XXI, no 71, julho, 2000.

EDWARDS, D. \& MERCER, N. El conociomiento compartido: el desarrollo da compreensión en aula. Barcelona: Ediciones Paidós, 1988.

ENGESTRÖM, Yrjö. Activity theory and individual and social transformation. In: ENGESTRÖM, Yrjö et al. Perspectives on activity theory. 3.ed. New York: Cambridge University Press, 1999. p. 19-38.

ENGUITA, M. F. Trabalho, escola e ideologia. São Paulo: Artmed, 1993 
FIGUERÊDO, K. L. \& JUSTI, R. S. Formação continuada de professores de Ciências: uma perspectiva de desenvolvimento dos conhecimentos docentes a partir de pesquisa-ação colaborativa. In: Anais do VI ENPEC, Florianópolis, 2006.

FIGUERÊDO, K. L. Formação continuada de professores de química buscando inovação, autonomia e colaboração: Análise do desenvolvimento de seus conhecimentos sobre modelagem a partir do envolvimento em pesquisa-ação em um grupo colaborativo. Dissertação de mestrado. Belo Horizonte: UFMG, 2008

FRACALANZA, H. O ensino de ciências no primeiro grau. São Paulo: Atual Editora, 1987.

FRANCHI, E. P. A insatisfação dos professores: consequências para a profissionalização. In: FRANCHI, E. P. (org.) A causa dos professores. Campinas: Papirus, 1995, pp. 17-90 (Coleção Magistério Formação e Trabalho Pedagógico).

FRANCO, M. A. S. Pesquisa-ação e prática docente: articulações possíveis. In: PIMENTA, S. G \& FANCO, M. A. S. Pesquisa em educação: possibilidades investigativas/formativas da pesquisa-ação. São Paulo: Loyola, 2008.

FREIRE, P. Pedagogia da autonomia: saberes necessários à pratica educativa. Rio de Janeiro: Paz e Terra, 2001.

FREITAS, M. T. A. Vygotsky e Bakhtin Psicologia e Educação: um intertexto. Juiz de ForaMG: Editora ática, 2003.

A abordagem sócio-histórica como orientadora da pesquisa qualitativa. In: Cadernos de Pesquisa, n. 116, p. 21-39, julho/2002.

FRIEDRICK, Janette. Lev Vigotski: mediação, aprendizagem e desenvolvimento, uma leitura filosófica e epistemologia. Campinas, SP: Mercado de Letra, 2012.

GARCEZ, A.; DUARTE, R. \& EISENBERG, Z. Produção e análise de videogravações em pesquisas qualitativas. In: Educação e Pesquisa, São Paulo, v. 37, n.2, p. 249-262, mai/ago. 2011.

GERALDO, A. C. H. Didática de Ciências Naturais na perspectiva histórico-crítica. Campinas, SP: Autores Associados, 2009.

GHEDIN, E. Da alienação da técnica à autonomia da critica. In: PIMENTA, S. G. e GHEDIN, E. (orgs.) Professor Reflexivo no Brasil gênese e crítica de um conceito. São Paulo: Cortez, 2002.

GHEDIN, E.; ALMEIDA, M. I.; LEITE, Y. U. F. Formação de Professores: Caminhos e Descaminhos da Prática. Brasília: Liber Livros, Editora, 2008.

GIOVANNI, L. M.; GUARNIERI, M. R.; MARIN, A. J. Diretrizes gerais e seus desdobramentos para o ensino na perspectiva de professoras primárias. In: MARIN, A. J.; GIOVANNI, L. M.; GUARNIERI, M. R. (orgs.). Pesquisa com Professores no Início da Escolarização. Araraquara, SP: Junqueira \& Marin, São Paulo, SP: FAPESP, 2009.

GIORDAN, M. Computadores e linguagens nas aulas de ciências. Ijuí: Ed. Unijuí, 2008. 
GÓES, J. Produção e sustentação de um coletivo docente: uma experiência de formação de professores dentro do universo profissional. Dissertação de Mestrado. Campinas, SP: Faculdade de Educação Unicamp, 2010.

GÓES, M. C. R. A abordagem microgenética na matriz histórico-cultural: uma perspectiva para o estudo da constituição da subjetividade. In: Caderno Cedes, ano XXI, nº 50, $\mathrm{abril} / 2000$.

GOMES, M. O. Grupos de pesquisa/formação: potencializando o desenvolvimento profissional de educadores de crianças pequenas. In: PIMENTA, S. G., GHEDIN, E. \& FRANCO, M. A. S. (orgs.). Pesquisa em Educação: alternativas investigativas com objetos complexo. São Paulo: Loyola, 2006.

GONZÁLEZ REY, F. L. Pesquisa qualitativa em psicologia: caminhos e desafios. São Paulo: Pioneira Thomson Learning, 2002.

JAN, M.; CHEE, Y. S.; TAN, M. E. Changing Science Classroom Discourse toward Doing Science: The Design of a Game-based Learning Curriculum. In: S. L. Wong et al. (Eds.) (2010). Proceedings of the 18th International Conference on Computers in Education. Putrajaya, Malaysia: Asia-Pacific Society for Computers in Education. In: http://yamsanchee.home.nie.edu.sg/Publications/2010/JanCheeTan_ICCE2010.pdf

JORDÃO, R. S. Tutoria e Pesquisa-ação no estágio supervisionado: contribuições para a formação de professores de Biologia. Tese de Doutorado, São Paulo: FEUSP, 2006.

KELLY, G. J. Discourse in Science Classrooms. In: Handbook of Research on Science, Mahwah, New Jersey London: LEA (Lawrence Erlbaum Associates, Publishers, 2007.

KEMMIS, S \& WILKINSON, M. A pesquisa-ação participativa e o estudo da prática, In: PEREIRA, J. E. D. ; ZEICHNER, K. M. A pesquisa na formação e no trabalho docente. Belo Horizonte: Autêntica, 2002.

LEMKE, Jay L. Aprender a hablar ciência: lenguaje, aprendizaje y valores. Barcelona: Paidós, 1997.

Investigar para el futuro de la educación científica: nuevas formas de aprender, nuevas formas de vivir. In: Enseñanza de las ciencias, 2006, 24(1), 5-12.

Teaching all the languages of science: words, symbols, images and actions. In: CONFERENCE ON SCIENCE EDUCATION, 1998. Barcelona. Disponível em: <http:/ /academic.brooklyn.cuny.edu/education/jlemke/sci-ed.htm>.

LEMOS, D. Trabalho docente nas universidades federais: tensões e contradições. In: Caderno CRH, Salvador, v. 24, n. spe 01, p. 105- 120, 2011.

LEONTIEV, Alexis N. Uma contribuição à teoria do desenvolvimento da psique infantil. In: VYGOTSKY, Lev Semenovich. Linguagem, desenvolvimento e aprendizagem. São Paulo: Edusp/Icone, 1991.

O desenvolvimento do psiquismo. Lisboa: Livros Horizonte LDA, 1978.

Actividade, consciência e personalidad. Havana: Edições Pueblo Y Educación, 1983. 
Linguagem e razão humana.Lisboa: Editorial Presença (S/D).

LIMA, V. M. M. Formação do professor polivalente e saberes docentes: um estudo a partir de escolas públicas. Tese de Doutorado. São Paulo: FEUSP, 2009.

LIMA, M. E. C. C.; MAUÉS, E. Uma releitura do papel da professora das séries iniciais no desenvolvimento e aprendizagem de ciências das crianças. In: Revista ENSAIO, vol.8, $\mathrm{n}^{\mathrm{o}} 02$, $\operatorname{dez} / 2006$.

LÓPEZ RODRÍGUEZ, R. y JIMÉNEZ ALEIXANDRE, M. P. ¿Podemos cazar ranas? Calidad de los argumentos de alumnado de primaria y desempeño cognitivo en el estudio de una charca. In: ENSEÑANZA DE LAS CIENCIAS, 2007, 25(3), 309-324.

LÜDKE, M e ANDRÉ, M.E.D.A. Pesquisa em Educação: Abordagens qualitativas. São Paulo: EPU, 1986.

LURIA, A. R. Pensamento e Linguagem: as últimas conferências de Luria. Porto Alegre: Artes Medicas, 2001.

MANZANO, C. S. Deslocamentos discursivos sobre a diversidade: análise de uma experiência de pesquisa-ação formativa com professores. Dissertação (Mestrado) - Faculdade de Educação, Universidade de São Paulo, São Paulo, 2009.

MARCELO, Carlos (2009). Desenvolvimento Profissional Docente: passado e futuro. Sísifo. Revista de Ciências da Educação, 08, pp. 7-22. Consultado em julho/2011 em http://sisifo.fpce.ul.pt

MÁRQUEZ, C.; IZQUIERDO, M. Y ESPINET, M. Comunicación multimodal en la clase de ciencias: el ciclo del agua. In: ENSEÑANZA DE LAS CIENCIAS, 2003, 21 (3), 371-386.

MARTINS, I. Dados como diálogo: construindo dados a partir de registros de interações discursivas em salas de aula de Ciências. In: Santos, F. M. T \& Greca, I. M (orgs.) A Pesquisa em Ensino de Ciências no Brasil e sua Metodologia. Ijuí: Editora Unijuí, 2006.

MARTINS, L. F.; MARTINS, I. Introduzindo a linguagem científica nas séries iniciais do ensino fundamental: o potencial das narrativas. In: Anais do VI ENPEC, Florianópolis, 2007.

MARTINS, L. M. A natureza histórico-social da personalidade. In.: Caderno CEDES. Abr. 2004, v.24, no.62, p. 82-99. Disponível em http://www.cedes.unicamp.br

MARTINS, L. M. A formação social da personalidade do professor: um enfoque vigotskiano. Campinas-SP: Autores associados, 2007.

MARX, K. O Capital, Volume I. São Paulo: Nova Cultural, 1985.

Manuscritos Econômicos-filosóficos de 1844. São Paulo: Boitempo, 2010.

Capítulo VI Inédito de O Capital, resultados do processo de produção imediata. São

Paulo: Centauro, 2004.

MARX, K. \& ENGELS, F. A ideologia alemã. São Paulo: Boitempo, 2007. 
MÁRQUEZ, C.; IZQUIERDO, M. Y ESPINET, M. Comunicación multimodal en la clase de ciencias: el ciclo del agua. In: ENSEÑANZA DE LAS CIENCIAS, 2003, 21 (3), 371-386.

MAZZITELLI, C. A. MATURANO, C. I. y MACÍAS, A. Estrategias de monitoreo de la comprensión en la lectura de textos de ciencias con dificultades. In: ENSEÑANZA DE LAS CIENCIAS, 2007, 25(2), 217-228.

MEHAN, Hugh. Learning lessons: social organization in the classroom. Cambridge, USA: Harward Press, 1979.

MEIRA, L. Análise microgenética e videografia: ferramentas de pesquisa em psicologia cognitiva. In: Temas em Psicologia, n ${ }^{\circ}$ 3, 1994.

MENDONÇA, D. H; AGUIAR, O.; SILVA, N. S. Participação dos estudantes no discurso de uma sala de aula de ciências: tensão entre discurso dialógico e de autoridade. In: XI EPEF, Curitiba, 2008.

MERCER, Neil - La construcción guiada del conocimiento - el habla de profesores y alumnos, Buenos Aires: Paidós, 1997.

200.

Palabras y mentes: cómo usamos el lenguaje para pensar juntos. Barcelona: Paidós,

MESNIER, Pierre-Marie \& MISSOTE Philippe (orgs). La recherche-action: Une autre manière de chercher, se former, transformer. Coleção Recherche-action en pratiques socialles. Paris: Éditions L'Harmattan, 2003.

MONCEAU, G. Como as instituições permeiam as práticas profissionais: Socioclinica institucional e formação de professores. In: PIMENTA, S. G. FRANCO, M. A. S. Pesquisa em educação: possibilidades investigativas da pesquisa-ação. São Paulo, Loyola, 2008.

MONTECINOS, C; GALLARDO, J. Concepções de pesquisa-ação entre professores chilenos do ensino fundamental: colocando o "nós" no centro. In: PEREIRA, J. E. D. ; ZEICHNER, K. M. A pesquisa na formação e no trabalho docente. Belo Horizonte: Autêntica, 2002.

MONTEIRO, S. B. Pesquisa-ação e produção de conhecimento na formação docente. In: PIMENTA, S. G \& FANCO, M. A. S. Pesquisa em educação: possibilidades investigativas/formativas da pesquisa-ação. São Paulo: Loyola, 2008.

MONTEIRO, M. A. A. SANTOS, D. A. TEIXEIRA, O. P. B. Caracterizando a autoria no discurso em sala de aula In: Investigações em Ensino de Ciências - V12(2), pp.205-225, 2007.

MONTEIRO, M. A. A. \& TEIXEIRA, O. P. B. Uma análise das interações dialógicas em aulas de ciências nas séries iniciais do ensino fundamental. In: Investigações em Ensino de Ciências, V9(3), pp. 243-263, 2004. Disponível em <http:/www.if.ufrg.br/public/ensino/revista.htm>

MORTIMER, E. F. Sobre chamas e cristais: a linguagem científica, a linguagem cotidiana e o ensino de ciências. In: CHASSOT, A. E.; OLIVEIRA, J. R. (orgs.) Ciência, Ética e Cultura na educação. São Leopoldo: Unisinos, p. 99-118, 1998. 
MORTIMER, E. F.; SCOTT, P. H. Atividade discursiva nas salas de aula de ciências: uma ferramenta sociocultural para analisar e planejar o ensino. In: Investigações em Ensino de Ciências, 7(2), 2002. Disponível emm <http:/www.if.ufrg.br/public/ensino/revsita.htm>

MOURA, M. O.; ARAÚJO, E. S; RIBEIRO, F. D.; PANOSSIAN, M. L. \& MORETTI, V. D. In: MOURA, M. O. (org.). A atividade pedagógica na teoria histórico cultural. Brasília: Liber livro, 2010.

. E Educador matemático na coletividade de formação: uma experiência com a escola pública. Tese de Livre Docente. São Paulo: FEUSP, 2000.

A Atividade de Ensino como Unidade Formadora. In: Bolema. Ano II. Número12. Rio Claro: UNESP, 1996, pp.29-43.

NASCIMENTO, T. G.; MARTINS, I. O texto de genética no livro didático de ciências: uma análise retórica crítica. In: Investigações em Ensino de Ciências, V10(2), pp. 255-278, 2005.

NÓVOA, A. Para o estudo sócio-histórico da gênese e desenvolvimento da profissão docente. In: Teoria e Educação, n. 4, 1991.

Os Professores na Virada do Milênio: do excesso dos discursos à pobreza das práticas. In: Educação e Pesquisa, São Paulo, v. 25, n. 1, p. 11-20, jan/jun. 1999.

NUNES-MACEDO, M. S. A; MORTIMER, E. F.; GREEN, J. A constituição das interações em sala de aula e o uso do livro didático: análise de uma prática de letramento no primeiro ciclo. In: Revista Brasileira da Educação, nº 25, 2004.

OLIVEIRA, M. K. Vygotsky: aprendizado e desenvolvimento: um processo sócio-histórico. São Paulo, Scipione, 2008.

OLIVEIRA, C. M. A. Do discurso oral ao texto escrito nas aulas de ciências. Tese de doutorado, São Paulo: FEUSP, 2009.

OLIVEIRA, R. M. M. A. \& PASSOS, C. L. B. Promovendo o desenvolvimento profissional na formação de professores: a produção de histórias infantis com conteúdo matemático. In: Ciência \& Educação, v. 14, n.2, p. 315-330, 2008.

PAIXÃO, M..F. y CACHAPUZ, A. La enseñanza de las ciencias y la formación de profesores de enseñanza primária para la reforma curricular: de la teoria a la práctica. In: Enseñanza de las Ciências, 17(1), 69-77, 1999.

PEDRANCINI, V. D.; CORAZZA-NUNES, M. J.; GALUCH, M. T. B. Mediação pedagógica e a formação de conceitos científicos sobre hereditariedade. In: Revista Electrónica de Enseñanza de la Ciências, Vol 10, nº 1, 109-132 (2011).

PENAGOS, R. A. La producción de conocimiento en la investigación acción pedagógica (IAPE): balance de una experimentación. In: Revista Educação e Pesquisa, Vol. 31, n. 03, set./dez. 2005, p. 503-519.

PENTEADO, H. D. A relação docência ciência sob a perspectiva da pesquisa-ação. In: PENTEADO, H. D. \& GARRIDO, E. (orgs). Pesquisa-ensino: a comunicação escolar na formação do professor. São Paulo: Paulinas, 2010. 
PEREIRA, J. E. D. A pesquisa dos educadores como estratégia para construção de modelos críticos de formação docente. In: . In: PEREIRA, J. E. D. ; ZEICHNER, K. M. A pesquisa na formação e no trabalho docente. Belo Horizonte: Autêntica, 2002.

PIMENTA, S. G. Pesquisa-ação critico-colaborativa: construindo seu significado a partir de experiências com a formação docente. In: Revista Educação e Pesquisa, Vol. 31, n. 03, set./dez. 2005, p. $521-539$.

PIMENTA, S. G. Pesquisa-ação critico-colaborativa: construindo seu significado a partir de experiências na formação e na atuação docente. In:PIMENTA, S. G., GHEDIN, E. \& FRANCO, M. A. S. (orgs.). Pesquisa em Educação: alternativas investigativas com objetos complexos. São Paulo: Loyola, 2006.

PIMENTA, S. G. e GHEDIN, E. (orgs.) Professor Reflexivo no Brasil gênese e crítica de um conceito. São Paulo: Cortez, 2002.

RIBEIRO, A. C. CORAZZA-NUNES, M. J. Análises de interações discursivas em sala de aula na perspective da teoria histórico-cultural. In: Anais do VI ENCONTRO NACIONAL DE PESQUISA EM EDUCAÇÃO EM CIÊNCIAS, Florianópolis, 2007.

RIGON, A. J; ASBAHR, F. S. F. \& MORETTI, V. D. Sobre o processo de humanização. In: MOURA. M. O. (Org.). A atividade pedagógica na teoria histórico-cultural. Brasília: Liber livros, 2010.

RIVARD, L. P; STRAW, S. B. The effect of talk and writing on learning science. Anexploratory study. Science Education, v. 84, n. 5, p. 566-593, 2000.

ROSA, M. I. F. P. S. \& SCHNETZLER, R. P. A investigação-ação na formação continuada de professores de ciências. In: Ciência e Educação, v. 9, n. 1, p. 27-39, 2003.

ROTH, W. M.; LAWLESS, D. Science, culture and the emergence of language. Science Education, Pennsylvania, USA, v. 86, n. 3, p. 368-85, 2002.

RUBTSOV, V. A atividade de aprendizado e os problemas referentes a formação do pensamento teórico dos escolares. In: GARNIER, C.; BEDNARZ, N.; ULANOVSKAYA, I. (Orgs.). Após Vygotsky e Piaget: perspectivas social e construtivista russa e ocidental. Porto Alegre: Artes Médicas, 1996.

SÁNCHEZ VÁZQUEZ, A. Filosofia da práxis. São Paulo, Expressão Popular, 2007.

SANTOS, W. L. P.; MORTIMER, E. F. Abordagem de aspectos sociocientíficos em aulas de ciências: possibilidades e limitações. In: Investigações em Ensino de Ciências- V14 (2), PP.191-218, 2009.

SASSERON, L. H. Alfabetização Científica no Ensino Fundamental: Estrutura e Indicadores deste processo em sala de aula. Tese de doutorado, FEUSP, São Paulo, 2008.

SASSERON, L. H. \& CARVALHO. A. M. P. Almejando a alfabetização científica no ensino fundamental: a proposição e a procura de indicadores do processo. In: Investigações em Ensino de Ciências — V13(3), pp.333-352, 2008 
SAVIANI, Demerval. Educação: do senso comum à consciência filosófica. $13^{\circ}$ edição, Campinas: Autores Associados, 1996. Disponível em:

http://www.visionvox.com.br/biblioteca/d/demerval-saviani-do-senso-comum-conscienciafilosofica.pdf

Pedagogia histórico-crítica: primeiras aproximações. 10a edição, Campinas-SP:

Autores Associados, 2008.

Trabalho e educação. In: Revista Brasileira de Educação. V. 12, n. 34, jan/abril/2007.

Escola e democracia. Campinas, SP: Autores Associados, 2009.

SANTOS, S. C. S.; TERÁN, A. F.; Maria Clara SILVA-FORSBERG, M. C. Analogias em livros didáticos de biologia no ensino de Zoologia. In: Investigações em Ensino de Ciências - V15(3), pp. 591-603, 2011

SCARINCI, A. L.; PACCA, J. L A. O professor de física em sala de aula: um instrumento para caracterizar sua atenção. In: Investigações em ensino de Ciências - V14(3), PP. 457-477, 2009.

SCHROEDER, E.; FERRARI, N.; MAESTRELLI, S. R. P.; A construção dos conceitos científicos em aulas de ciências: a teoria histórico-cultural do desenvolvimento como referencial par análise de um processo de ensino sobre sexualidade humana. In: ALEXANDRIA Revista de Educação em Ciências e Tecnologia , v. 3, n. 1. P.21-49, maio 2010.

SERRÃO, M. I. B. Superando a racionalidade técnica na formação: sonho de uma noite de verão. In: PIMENTA, S. G. e GHEDIN, E. (orgs.) Professor Reflexivo no Brasil gênese e crítica de um conceito. São Paulo: Cortez, 2002.

SELLES, S. E. Formação continuada e desenvolvimento profissional de professores de ciências: anotações de um projeto. In: Ensaio - Pesquisa em Educação em Ciências, v. 02, n. 2 - Dez. 2002.

SIGNORINI, N. T. P. A pesquisa na formação de professores: a perspectiva do professor pesquisador. Tese de Doutorado, Campinas, SP: Faculdade de Educação da Unicamp, 2006.

SILVA, L. H. A. \& SCHNETZLER, R. P. O discurso pedagógico de um professor e a elaboração de conhecimentos científicos. In: Revista ENSAIO - vol 11, no 1 - junho de 2009 págs. $55-70$.

SILVA, A. C. T. e MORTIMER, E. F. Caracterizando estratégias enunciativas em uma sala de aula de química: aspectos teóricos e metodológicos em direção à configuração de um gênero do discurso In: Investigações em Ensino de Ciências - V15(1), pp. 121-153, 2010.

SMOLKA, A. L. B. A atividade criadora do homem: a trama e o drama (apresentação). IN: Vigotski, L. S. Imaginação e criação na infância. São Paulo: Ática, 2009.

Sobre significação e sentido: uma contribuição à proposta de rede de significações. In: ROSSETI-FERREIRA, M. C., AMORIM, A. P. S., SILVA, A.P. S, \& CARVALHO, A. 
M, A. (orgs). Rede de significações e o estudo do desenvolvimento humano (Vol. I, pp. 35-49) Porto Alegre: Artes Médicas, 2004.

O (im) próprio e o (im) pertinente na apropriação das praticas sociais. In: Caderno Cedes, ano XX, no 50, abril/2000.

; NOGUEIRA, A. L. H. (orgs). Questões de desenvolvimento humano: práticas e sentidos. Campinas - SP: Mercado das Letras, 2010.

SOUZA V. F. M. A importância da pergunta na promoção da alfabetização científica em aulas investigativas de Física. Dissertação de mestrado. São Paulo: USP (Faculdade de Educação, Instituto de Física, Instituto de Química e Instituto de Biociências), 2012.

SOUZA, S. C. \& ALMEIDA, M. J. P. M. A escrita no ensino de ciências: autores do ensino fundamental. In: Ciência \& Educação, v. 11, n. 3, p. 367-382, 2005.

TALIZINA, Nina. La teoría da la actividad aplicada a la enseñanza. México: Benemérita Universidade Autonoma de Puebla, 2009.

TARDIF, M.; LESSARD, C. O trabalho docente: Elementos para uma teoria. Petrópolis: Vozes, 2005.

TEIXEIRA, E. Vigotski e o materialismo dialético: uma introdução aos fundamentos filosóficos da Psicologia Histórico-Cultural. Pato Branco: FADEP, 2005

VAN ACKER, M. T. V. A reflexão e a prática docente: considerações a partir de uma pesquisa-ação. Tese de Doutorado, São Paulo, FEUSP, 2008.

VICENTINI, A. A. F. O trabalho coletivo docente: contribuições para o desenvolvimento profissional dos professores. Dissertação de Mestrado, Campinas, SP: Faculdade de Educação da Unicamp, 2006.

VIEIRA, R. D. \& NASCIMENTO, S. S. Uma visão integrada dos procedimentos discursivos didáticos de um formador em situações argumentativas de sala de aula. In: Ciência \& Educação, v. 15, n. 3, p. 443-457, 2009.

VYGOTSKY, L. S. The colected Works of L. S. Vygotsky, Vol I, Problems of General Psycology incluindo o volume Thinking and Speech, R. W. Rieber e A. S. Carton (orgs.), N. Minick (trad.), NY Plenun Press, 1987.

Linguagem, desenvolvimento e aprendizagem. São Paulo: Edusp/Icone, 1991.

VIGOTSKI, L. S. A construção do pensamento e da linguagem. São Paulo, Martins Fontes, 2009 b.

A imaginação e criação na infância. São Paulo, Ática, 2009a.

Teoria e método em psicologia. São Paulo: Martins Fontes, 2004.

Obras Escogidas, Tomo III. Madri: Aprendizaje Visor, 2000 
A formação social da mente: o desenvolvimento dos processos psicológicos superiores. São Paulo: Martins Fontes, 2010.

WEIGERT, C.; VILLANI, A.; FREITAS, D. A interdisciplinaridade e o trabalho coletivo: Análise de um planejamento interdisciplinar. In: Ciência \& Educação, v. 11. n. 1. P. 145-164, 2005.

WERTSCH, James V. \& SMOLKA, Ana Luzia B. Continuando o diálogo Vygotsky, Bakhtin e Lotman. In: Vygotsky em foco: pressupostos e desdobramentos. Campinas, SP: Papirus, 6a edição, 2003.

WERTSCH, J. V. La mente en acción. Argentina: Aique, 1999. Press, 1985

Vygotsky and the social formation of mind. Cambridge, Mass.: Harvad University

Voices of the mind. A sociocultural appproach to mediater action. Cambridge, Mass., Harvard University Press, 1991. 
APÊNDICES 


\section{Apêndice I - Apresentação geral dos dados coletados}

\section{Quadro: Coleta de dados 2008/2009/2010}

\begin{tabular}{|c|c|c|c|}
\hline Data & Temática/conceituação & Conteúdo da aula & Suporte de arquivo \\
\hline & Professora Mara & & \\
\hline $29 / 05 / 2008$ & $\begin{array}{c}\text { Emersão e submersão do } \\
\text { submarino; ambiente } \\
\text { marinho }\end{array}$ & $\begin{array}{r}\text { Finalização da } \\
\text { sequência com escrita } \\
\text { coletiva }\end{array}$ & Disco DVD (removível) \\
\hline $30 / 05 / 2008$ & $\begin{array}{r}\text { Flutuabilidade das } \\
\text { embarcações }\end{array}$ & $\begin{array}{r}\text { Desafio matemático: } \\
\text { Travessia do rio }\end{array}$ & Disco DVD \\
\hline $06 / 06 / 2008$ & $\begin{array}{c}\text { Flutuabilidade do } \\
\text { barquinho de alumínio }\end{array}$ & $\begin{array}{r}\text { Texto "o barquinho } \\
\text { equilibrista" }\end{array}$ & Disco DVD \\
\hline $13 / 06 / 2009$ & Embarcações & $\begin{array}{r}\text { Tipos de navios e } \\
\text { cruzadinha }\end{array}$ & Disco DVD \\
\hline $19 / 06 / 2008$ & Embarcações & $\begin{array}{r}\text { Finalizando a } \\
\text { cruzadinha }\end{array}$ & Disco DVD \\
\hline 06/08/2008 & $\begin{array}{l}\text { Flutuabilidade das } \\
\text { embarcações }\end{array}$ & Água de lastro & Disco DVD \\
\hline $21 / 08 / 2008$ & Cadeia alimentar & $\begin{array}{l}\text { Jogo presa e } \\
\text { predador }\end{array}$ & Disco DVD \\
\hline $09 / 2008$ & Cadeia alimentar & $\begin{array}{l}\text { Tabela jogo presa e } \\
\text { predador }\end{array}$ & Disco DVD \\
\hline & Professora Andreza & & \\
\hline $05 / 06 / 2008$ & $\begin{array}{l}\text { Flutuabilidade do } \\
\text { barquinho de alumínio }\end{array}$ & $\begin{array}{l}\text { Experimentação, } \\
\text { relatório e escrita } \\
\text { coletiva }\end{array}$ & Disco DVD \\
\hline $13 / 06 / 2008$ & $\begin{array}{l}\text { Flutuabilidade do } \\
\text { barquinho de alumínio }\end{array}$ & $\begin{array}{l}\text { Texto: o barquinho } \\
\text { equilibrista }\end{array}$ & Disco DVD \\
\hline & Professora Verônica & & \\
\hline $26 / 03 / 2008$ & $\begin{array}{l}\text { Emersão e Submersão do } \\
\text { submarino }\end{array}$ & $\begin{array}{l}\text { Experimentação e } \\
\text { roda de conversa }\end{array}$ & Disco DVD \\
\hline $08 / 04 / 2008$ & $\begin{array}{l}\text { Emersão e submersão do } \\
\text { Submarino }\end{array}$ & Texto científico & Disco DVD \\
\hline $16 / 04 / 2008$ & Submarino & $\begin{array}{l}\text { História do } \\
\text { submarino }\end{array}$ & Disco DVD \\
\hline $28 / 05 / 2008$ & $\begin{array}{l}\text { Flutuabilidade das } \\
\text { embarcações }\end{array}$ & $\begin{array}{l}\text { Desafio matemático: } \\
\text { Travessia do rio }\end{array}$ & Disco DVD \\
\hline
\end{tabular}




\begin{tabular}{|c|c|c|c|}
\hline $04 / 06 / 2008$ & $\begin{array}{l}\text { Flutuabilidade do } \\
\text { barquinho de alumínio }\end{array}$ & $\begin{array}{l}\text { Experimentação e } \\
\text { roda de conversa }\end{array}$ & Disco DVD \\
\hline $06 / 06 / 2008$ & $\begin{array}{l}\text { Flutuabilidade do } \\
\text { barquinho de alumínio }\end{array}$ & $\begin{array}{l}\text { Texto: barquinho } \\
\text { equilibrista }\end{array}$ & Disco DVD \\
\hline $09 / 06 / 2008$ & Tipos de navios & Leitura de texto & Disco DVD \\
\hline $13 / 06 / 2009$ & Tipos de navios & Cruzadinha & Disco DVD \\
\hline $18 / 06 / 2009$ & $\begin{array}{l}\text { Flutuabilidade das } \\
\text { embarcações }\end{array}$ & Água de lastro & Disco DVD (02) \\
\hline $06 / 08 / 2008$ & Cadeia alimentar & $\begin{array}{l}\text { Instruções do jogo } \\
\text { presa e predador }\end{array}$ & Disco DVD \\
\hline $19 / 08 / 2008$ & Cadeia alimentar & $\begin{array}{l}\text { O jogo Presa e o } \\
\text { predador }\end{array}$ & Disco DVD \\
\hline \multirow[t]{2}{*}{$19 / 08 / 2008$} & Jogo Presa e predador & $\begin{array}{l}\text { Análise das tabelas } \\
\text { sobre as rodadas do } \\
\text { jogo }\end{array}$ & Disco DVD \\
\hline & Professora Olga & & \\
\hline $27 / 05 / 2008$ & $\begin{array}{l}\text { Flutuabilidade das } \\
\text { embarcações }\end{array}$ & $\begin{array}{l}\text { Desafio matemático: } \\
\text { travessia do rio }\end{array}$ & Disco DVD (02) \\
\hline $03 / 06 / 2008$ & $\begin{array}{l}\text { Flutuabilidade do } \\
\text { barquinho de alumínio }\end{array}$ & $\begin{array}{l}\text { Experimentação e } \\
\text { roda de conversa }\end{array}$ & Disco DVD \\
\hline $05 / 06 / 2008$ & $\begin{array}{l}\text { Flutuabilidade do } \\
\text { barquinho de alumínio }\end{array}$ & $\begin{array}{l}\text { Texto: barquinho } \\
\text { equilibrista }\end{array}$ & Disco DVD \\
\hline $09 / 06 / 2008$ & Tipos de navios & Leitura de texto & Disco DVD \\
\hline $17 / 06 / 2008$ & Tipos de navios & Cruzadinha & Disco DVD (02) \\
\hline $12 / 08 / 2008$ & $\begin{array}{l}\text { Flutuabilidade das } \\
\text { embarcações }\end{array}$ & Água de lastro & Disco DVD \\
\hline \multirow[t]{2}{*}{$15 / 08 / 2008$} & Cadeia alimentar & $\begin{array}{l}\text { Jogo Presa e } \\
\text { predador }\end{array}$ & Disco DVD \\
\hline & $\begin{array}{l}\text { REUNIÕES NA } \\
\text { ESCOLA E NA } \\
\text { FEUSP }\end{array}$ & & \\
\hline $11 / 03 / 2008$ & ESCOLA - "fórum I" & $\begin{array}{l}\text { Emersão e } \\
\text { submersão do } \\
\text { submarino }\end{array}$ & Disco DVD \\
\hline $07 / 04 / 2008$ & FEUSP - "fórum II" & $\begin{array}{l}\text { Alfabetização } \\
\text { científica }\end{array}$ & Disco DVD (03) \\
\hline $13 / 05 / 2008$ & ESCOLA - "fórum I" & Flutuabilidade & Disco DVD (02) \\
\hline $27 / 05 / 2008$ & ESCOLA - "fórum I" & $\begin{array}{l}\text { Cadeia alimentar- } \\
\text { jogo Presa e } \\
\text { predador }\end{array}$ & Disco DVD \\
\hline
\end{tabular}




\begin{tabular}{|c|c|c|c|}
\hline $11 / 06 / 2008$ & FEUSP - "fórum II" & Cartografia & Disco DVD (03) \\
\hline $27 / 08 / 2008$ & FEUSP - "fórum II" & $\begin{array}{l}\text { Metodologia de } \\
\text { pesquisa }\end{array}$ & Disco DVD \\
\hline \multirow[t]{3}{*}{$18 / 09 / 2008$} & ESCOLA - "fórum I" & $\begin{array}{l}\text { Narrativa Semana de } \\
\text { Educação }\end{array}$ & Disco DVD \\
\hline & FEUSP - "fórum II" & $\begin{array}{l}\text { Alfabetização e } \\
\text { letramento }\end{array}$ & Disco DVD \\
\hline & $\begin{array}{l}\text { REUNIÕES FEUSP } \\
\text { E EMEF } 2009\end{array}$ & & \\
\hline $11 / 03 / 2009$ & Escola & $\begin{array}{l}\text { Transformações de } \\
\text { energia }\end{array}$ & Disco DVD \\
\hline $15 / 04 / 2009$ & Escola & Reflexão da luz & Disco DVD \\
\hline $27 / 04 / 2009$ & FEUSP & Cultura escolar & Disco DVD \\
\hline $20 / 05 / 2009$ & Escola & Reações químicas & Disco DVD \\
\hline \multirow[t]{2}{*}{$02 / 12 / 2009$} & FEUSP & História local & Disco DVD \\
\hline & Profa. Áurea & & \\
\hline 03/03/2009 & $\begin{array}{l}\text { Distribuição de água: da } \\
\text { Caixa d'água às torneiras }\end{array}$ & $\begin{array}{l}\text { Interpretação de } \\
\text { plantas de casas }\end{array}$ & Disco DVD \\
\hline $14 / 03 / 2009$ & Pressão da água & $\begin{array}{l}\text { Experimentação e } \\
\text { roda de conversa }\end{array}$ & Disco DVD \\
\hline $24 / 03 / 2009$ & Pressão da água & $\begin{array}{l}\text { Leitura de texto } \\
\text { científico }\end{array}$ & Disco DVD \\
\hline \multirow[t]{2}{*}{$28 / 04 / 2009$} & $\begin{array}{l}\text { Proporções de água no } \\
\text { planeta Terra }\end{array}$ & Textos e mapas & Disco DVD \\
\hline & Profas. Sofia e Mara & & \\
\hline $19 / 03 / 2009$ & $\begin{array}{l}\text { Transformações de energia } \\
\text { em uma rampa }\end{array}$ & $\begin{array}{l}\text { Experimentação e } \\
\text { roda de conversa }\end{array}$ & Disco DVD \\
\hline $02 / 04 / 2009$ & $\begin{array}{l}\text { Transformações de energia } \\
\text { em uma rampa }\end{array}$ & Texto científico & Disco DVD \\
\hline $30 / 04 / 2009$ & $\begin{array}{l}\text { Transformações de energia } \\
\text { em um circuito elétrico }\end{array}$ & $\begin{array}{l}\text { Experimentação e } \\
\text { roda de conversa }\end{array}$ & Disco DVD \\
\hline $05 / 06 / 2009$ & $\begin{array}{l}\text { Transformações de energia } \\
\text { em reações químicas }\end{array}$ & Texto científico & Disco DVD \\
\hline $\begin{array}{l}\text { 24/06/2009 } \\
\text { Mara }\end{array}$ & $\begin{array}{l}\text { Transformações de energia } \\
\text { na combustão do papel }\end{array}$ & $\begin{array}{l}\text { Experimentação e } \\
\text { roda de conversa }\end{array}$ & Disco DVD \\
\hline $25 / 06 / 2009$ & $\begin{array}{l}\text { Transformações de energia } \\
\text { na combustão do papel }\end{array}$ & $\begin{array}{l}\text { Experimentação e } \\
\text { roda de conversa }\end{array}$ & Disco DVD \\
\hline
\end{tabular}




\begin{tabular}{|l|l|l|l|}
\hline Sofia & & & \\
\hline $\begin{array}{l}\text { Coleta de dados } \\
\mathbf{2 0 1 0 / 2 0 1 1}\end{array}$ & $\begin{array}{l}\text { Dinossauros e pré-história } \\
\text { humana }\end{array}$ & Roda de conversa & $\begin{array}{l}\text { Disco DVD e arquivo } \\
\text { digital }\end{array}$ \\
\hline 2010 & Entrevista I & $\begin{array}{l}\text { Trajetória } \\
\text { profissional }\end{array}$ & Arquivo digital \\
\hline $10 / 11 / 2011$ & Entrevista II & $\begin{array}{l}\text { Complemento da } \\
\text { trajetória } \\
\text { profissional. }\end{array}$ & Arquivo digital \\
\hline
\end{tabular}




\section{Apêndice II - Atividade investigativa de Ensino: Dinossauros e a pré-} história humana

\section{Problema de Ensino:}

Como organizar os conhecimentos das crianças sobre os dinossauros e levá-las a aprender mais a respeito? Como levá-las a desenvolver noções gerais sobre a pré-história humana?

Ações do grupo de professoras: estruturação da atividade investigativa de aprendizagem questão inicial para introduzir; delimitação dos problemas de aprendizagem e das ações gerais; seleção e produção de textos para os alunos; seleção e organização das atividades experimentais - (fazendo fósseis em argila; fazendo fósseis em esmalte incolor; construção de um sítio arqueológico); seleção dos vídeos a serem projetados; delimitação dos objetivos.

Objetivos docentes: organizar e ampliar os conhecimentos das crianças a respeito dos dinossauros; leva-las ao desenvolvimento de noções gerais sobre o homem da caverna, suas características, modos de sobrevivência e modos de comunicação; levá-las à apropriação dos conceitos de fósseis e sítio arqueológico;

\section{Atividade de Aprendizagem - Dinossauros e a pré-história humana}

Esta atividade foi planejada para crianças na faixa etária de 7 a 8 anos, cursando o $2^{\circ}$ ano/série. Entretanto, pode ser desenvolvida para os demais anos do Ciclo I, desde que haja o aprofundamento conceitual adequado a cada ano.

\section{Ações:}

1. Introdução do tema:

Painel geral sobre os conhecimentos dos alunos sobre os dinossauros

- O que sabemos sobre os dinossauros?

- Quais animais se parecem com os dinossauros?

2. Para pesquisar junto aos familiares:

- Existia ser humano na época dos dinossauros? 
- O que aconteceu no planeta Terra que fez os dinossauros entrarem em extinção?

- Recorte figuras de dinossauros para montagem de um painel na classe.

3. Roda de conversa na classe:

- Apresentação dos resultados da pesquisa realizada com os familiares.

Visão cientifica e visão religiosa sobre a vida dos dinossauros no planeta Terra - leitura de partes do livro religioso trazido pelo aluno Artur, cujo conteúdo afirma ter existido dinossauros na arca de Noé; explicitação das hipóteses científicas pela professora.

Lista de animais que vivem atualmente e que se parecem com dinossauros. Causas das semelhanças; quais dos animais apresentados participam da Classe, da qual o dinossauro faz parte.

Roda de conversa na classe:

4. Questão norteadora da conversa: os dinossauros foram extintos há milhões de anos. Na sua opinião, como é possível sabermos tantas coisas sobre eles, nos dias de hoje?

Leitura de um fragmento de texto: "Paleontólogo" (Fonte: site IBGE teen).

5. Projeção do Vídeo: "Era do Gelo"

6. Conversa sobre o conteúdo do filme projetado

7. Atividade em grupo: Confecção de cartazes sobre os dinossauros

8. Leitura de fragmento de texto: a teoria da extinção dos dinossauros (produzido pelas professoras).

9. Produção escrita sobre "o que aprendemos sobre os dinossauros?"

10. Montagem de fósseis em argila no laboratório de ciências

11. Produção escrita de um relatório sobre a montagem dos fósseis.

12. Levantamento geral dos conhecimentos sobre a pré-história humana - como eram e como viviam os homens da caverna?

13. Para pensar e responder: Será que os homens escreviam? Como será que eles se comunicavam?

14. Leitura do texto: "Alguém passou por aqui antes" (extraído do livro didático Minha Vida Na Escola, Ciências, Livro 3, de autoria de Wanderley Carvalho e Carmen Carvalho, Pueri Domus, Escolas Associadas. 
15. Roda de conversa no laboratório de ciências sobre o que se aprendeu com os estudos sobre os dinossauros e o homem da caverna

16. Montagem do vale dos dinossauros e do sítio arqueológico no laboratório de ciências.

17. Exposição na Feira Cultural da escola - vale dos dinossauros, sítio arqueológico, textos explicativos produzidos pelas professoras e alunos. 
ANEXOS 
ANEXO I: Carta do Movimento de Educação do bairro de Perus ao Secretário Municipal de Educação

\section{PERUS - ANHANGÜERA EM BUSCA DA QUALIDADE DA EDUCAÇÃO}

Tendo em vista o I Seminário de Educação Perus - Anhangüera, realizado no último dia 23 de agosto de 2008, no Centro Pastoral Santa Fé, decidiu-se:

$1^{\circ}$ - apoiar políticas públicas que visem a melhoria da qualidade de ensino das escolas públicas, tais como: construção de escolas, manutenção dos equipamentos, diminuição do número de alunos por sala de aula, horário pedagógico, valorização da carreira do profissional de educação, etc...;

$2^{\circ}$ - apoiar práticas pedagógicas dos estabelecimentos de ensino voltadas para a construção do conhecimento e vinculadas à realidade dos alunos;

$3^{\circ}$ - apoiar parcerias que tenham como objetivo a melhoria dos espaços públicos, tanto no aspecto material quanto no humano;

$4^{\circ}$ - repudiar qualquer mudança que venha prejudicar a organização e funcionamento do projeto pedagógico das unidades de ensino;

$5^{\circ}$ - repudiar qualquer projeto de reforma sem prévio planejamento e sem diálogo com a comunidade escolar;

$6^{\circ}$ - repudiar qualquer desmonte dos espaços pedagógicos das escolas como, por exemplo, o Laboratório de Ciências da EMEF "Cândido Portinari", localizada em Perus, o qual desenvolve o projeto "Mão na Massa", promovido pela SME/SP, em perfeita sintonia com o programa "Ler e Escrever", somado aos projetos desenvolvidos com o Laboratório de Ensino de Física - FE/USP, e agora na expectativa de projeto com o CNPq. Sabemos que a articulação de todos esses projetos incide sobre a formação continuada dos professores e conseqüente melhoria da aprendizagem dos alunos. Não podemos aceitar a destruição de uma conquista da comunidade, cuja história está registrada não só nos arquivos acadêmicos, mas também nos corações de todos os envolvidos nessa luta e cujo trabalho é destaque na rede municipal de ensino de São Paulo.

Por fim, o movimento de educação afirma seu interesse em debater e interferir nas políticas públicas da região e coloca-se pronto para, junto com os governos municipal e estadual, defender uma escola pública gratuita e de qualidade para todos.

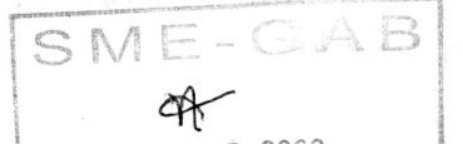




\section{Anexo II - Extratos das entrevistas cedidas pela Professora Verônica}

\section{ENTREVISTA I - professora, entrevistadora I (EI) e entrevistadora II (EII)}

\begin{tabular}{|c|c|}
\hline E1 & $\begin{array}{l}\text { (...) eu estou trabalhando com a ideia de competência docente, estou usando } \\
\text { o referencial de competências e aí, analisar tanto a sala de aula, como esta } \\
\text { questão da escola também, do que acontece aqui na escola pra se tornar essa } \\
\text { escola diferenciada, que tem essa participação dos professores que tem esse } \\
\text { grupo de trabalho e também a questão da parceria de trazer novas } \\
\text { sequências, de trazer coisas novas pra escola, assim: nesse sentido, é... e aí, } \\
\text { pra saber um pouco o que você acha de todo esse processo, desse grupo } \\
\text { também que se reúne, que não eram apenas reuniões feitas com a } \\
\text { universidade mas também entre vocês, estas reuniões que vocês tem aqui na } \\
\text { escola, a questão mesmo das reuniões que foram feitas com a universidade, } \\
\text { a inserção deste projeto aqui na escola: quando você entrou aqui na escola, } \\
\text { desculpa? }\end{array}$ \\
\hline Profa & Faz quatro anos... \\
\hline E1 & Quando você começou já existia o laboratório de Ciências, né? \\
\hline EII & O projeto começou há 3 anos. \\
\hline E1 & $\begin{array}{l}\text { Há } 3 \text { anos, mas quando você começou já tinha a Coord aqui que desenvolvia } \\
\text { um ensino diferenciado, que já tinham criado um laboratório de ciências... } \\
\text { aí, queria que você pensasse um pouco na sua experiência... há quantos anos } \\
\text { que você dá aulas? É uma coisa que eles pediram pra eu colocar... }\end{array}$ \\
\hline Profa & Há 20 anos... \\
\hline E1 & Há 20 anos... \\
\hline E2 & $\begin{array}{l}\text { Ó, posso dar uma sugestão, aí ela vai emendando? Também a minha } \\
\text { pergunta, o que interessa você responder, que eu também vou trabalhar um } \\
\text { pouquinho com você, seria assim: o que te tornou, durante toda a sua vida a } \\
\text { professora que você é hoje? Entendeu? Queria que você contasse um pouco } \\
\text { dessa sua história... }\end{array}$ \\
\hline Profa & Da minha trajetória? \\
\hline E2 & $\begin{array}{l}\text { É, da sua trajetória, dessa tua história de formação profissional, da área da } \\
\text { docência, aí você emenda com essas perguntas que ela fez, que é: até que } \\
\text { ponto o projeto da USP.. }\end{array}$ \\
\hline E1 & $\widehat{E}$, eu trouxe mais ou menos umas coisas pra perguntar... \\
\hline E2 & $\begin{array}{l}\text { Te... ajudou nesse processo de formação pra que você, se tornasse a } \\
\text { professora que você é hoje, né? }\end{array}$ \\
\hline Profa & Posso falar? \\
\hline E1 & Pode.. \\
\hline Profa & $\begin{array}{l}\text { Bom, assim... acho que o que me ajudou muito, foi quando eu comecei, que } \\
\text { eu fiz o magistério no interior e no interior eu aprendi assim: que eu tinha } \\
\text { que chegar na sala de aula, abrir a cartilha e dar aula. Tinha até musiquinha } \\
\text { pra cada letra, da cartilha, foi assim: foi bem massante meu magistério, mas } \\
\text { foi bom. }\end{array}$ \\
\hline E2 & Foi há quanto tempo atrás, isso? \\
\hline Profa & $\begin{array}{l}\text { Eu me formei em } 89 \text { no magistério, fiz } 4 \text { anos. Não queria fazer magistério, } \\
\text { sempre quis ser tradutora interprete ou aeromoça (risos), nada a ver, né? } \\
\text { Mas tudo bem... Aí, quando eu me formei no magistério, eu tive a chance de } \\
\text { vir morar em São Paulo, em Francisco Morato, porque no interior não tinha } \\
\text { aula... essas coisas. Então, na realidade eu comecei a dar aulas mais pela }\end{array}$ \\
\hline
\end{tabular}




\begin{tabular}{|c|c|}
\hline & $\begin{array}{l}\text { vontade assim ‘eu vou sair de Novo Horizonte', eu vou sair do interior, que } \\
\text { eu não gostava, queria viver outras coisas, enfim... E aí, quando eu cheguei } \\
\text { em Francisco Morato, eu peguei uma turma que estava começando a ter } \\
\text { contato com os estudos da Emília Ferrero. E era um grupo de estudo muito } \\
\text { forte na D.E. de Caieiras, só que eu só ouvia, eu ia em reunião, ficava } \\
\text { ouvindo, mas eu não sabia direito nada... aí assim, sendo bem sincera: o que } \\
\text { me tocou, é que eu ouvia falar assim: tem uma nova forma de alfabetizar, } \\
\text { tem uma nova forma de aprender, tem uma nova forma de ensinar, mas eu } \\
\text { tava com as coisas que eu tinha trazido do magistério e tava tudo certo... aí } \\
\text { numa aula, eu dava aula de alfabetização de adultos, lá em Morato. }\end{array}$ \\
\hline & $\begin{array}{l}\text { Aí, numa aula, eu nunca esqueço, numa aula, teve um aluno meu, eu tinha } \\
\text { dado a lição do periquito. E eu queria que eles escrevessem palavras com } \\
\text { 'que', 'qui'. Ai... eu to contando essa história só pra assim: o que eu fez eu } \\
\text { mudar, tá? O que fez eu pensar em outras coisas. Que tudo o que eu tava } \\
\text { ouvindo de novo, não tava muito claro pra mim, eu tava ouvindo mas não } \\
\text { tava botando em prática e eu tinha, não tinha nenhum ano de magistério, né? } \\
\text { Me formei em } 89,90 \text { foi isso! Quer dizer, eu tinha começado mesmo a dar } \\
\text { aulas: tinha } 19 \text { anos, enfim... eu tinha dado a lição do periquito e esse meu } \\
\text { aluno, falou assim, eu mandei fazer uma lição de palavras com 'que' e com } \\
\text { 'qui', aí, eu lembro que eu cheguei nele e ele punha o 'k' e o 'i' no “qui’. E } \\
\text { aí eu: 'olha eu já te falei o que é o 'q' o 'u' e o 'i'. Ai, tadinho... Aí, ele } \\
\text { virou pra mim e falou assim: Ah, professora, é que eu achei que pudesse ser } \\
\text { o 'ki' do chokito! Aí ele me respondeu isso! E eu falei: Mas o que é que tem } \\
\text { a ver o 'ki' do chokito? Aí ele falou: é... o 'ki'... e ficou assim, sem me } \\
\text { responder. Mas aí deu uma sensação tão estranha, aí, tudo aquilo que eu tava } \\
\text { ouvindo nas reuniões que eu tava indo, sabe? }\end{array}$ \\
\hline E2 & Quais reuniões? \\
\hline Profa & Oi? \\
\hline E2 & Quais reuniões que você tava indo? \\
\hline Profa & $\begin{array}{l}\text { Então, ia na DE de Caieiras que o pessoal tava estudando a psicogênese da } \\
\text { língua escrita, e tinha aquelas leituras, que os alunos vão pra escola, que não } \\
\text { são uma tabula rasa, eles já tem um conhecimento. Sabe tudo aquilo? Eu } \\
\text { ouvi aquilo mas eu ... eu não entendia o que aquilo queria dizer... }\end{array}$ \\
\hline E2 & Não fazia relação. \\
\hline Profa & $\begin{array}{l}\text { Não, eu não estabelecia relações daquilo com a minha prática e eu ia nas } \\
\text { reuniões porque eu tinha que ir... porque a gente era convocado pelo estado, } \\
\text { tudo... aí, me deu um estalo, aí eu falei: nossa, tem alguma coisa diferente! E } \\
\text { aí eu lembro que eu cheguei e comentei com a minha irmã e minha irmã já } \\
\text { tava fazendo o curso porque ela dava aula há mais tempo ela falou pra eu } \\
\text { procurar uma pessoa lá na rede de caieiras, que na época que era a Lúcia, } \\
\text { que quando eu cheguei pra ela e contei essa história ela se apaixonou. Falou: } \\
\text { Nossa! Você tem que aprender! Você tem que.. Nossa, você lida com } \\
\text { adultos, menina? Nossa, eles têm uma vivência. Aí que eu fui entender... aí } \\
\text { que eu cheguei na sala e fui perguntar, o que eu não sabia, porque eu } \\
\text { chegava e dava a cartilha, entendeu? Aí que eu cheguei e perguntei: olha... } \\
\text { você tem que saber primeiro o que eles trabalham, aí que eu fui saber que } \\
\text { esse meu aluno era repositor de supermercado. }\end{array}$ \\
\hline E2 & Eram adultos? \\
\hline Profa & $\begin{array}{l}\text { Eram adultos! Eram adultos, eram adultos! Analfabetos e eu dando a } \\
\text { cartilha, coitados... BA-be-bi-bo-bu, da-de-di-do-du... e eu achando que eles }\end{array}$ \\
\hline
\end{tabular}




\begin{tabular}{|c|c|}
\hline & $\begin{array}{l}\text { tinham que engolir aquilo, coitados, e eles tinham toda uma vivência, só que } \\
\text { eu não sabia o que fazer com a vivência deles na sala de aula. Aí, o que é } \\
\text { que aconteceu, aí parece que me deu um... sabe? Aí que eu fui entender isso, } \\
\text { de aproveitar o que o aluno já sabe na sala de aula. Aí eu comecei a fazer } \\
\text { curso de alfabetização. Aí... no primeiro ano. Aí no segundo ano, que eu falo } \\
\text { que foi uma sorte que eu dei, muito grande, a FB começou a dar um curso } \\
\text { que agora eu não vou lembrar o nome... mas era assim, eles davam curso pra } \\
\text { professores e os professores voltavam pras diretorias de ensino e aplicavam } \\
\text { aquele curso pra outros professores, era pro professor formador, uma coisa } \\
\text { assim, eu não lembro o nome. E aí uma... e aí eu já tava gostando de ler } \\
\text { aquelas coisas, de aprender... aí uma amiga minha me ligou um dia e falou: } \\
\text { "ó, precisam de alguém pra fazer um curso na FD na área de educação de } \\
\text { adultos, e ninguém quer... aí, como você dá aula em alfabeti... aí eu quis, eu } \\
\text { dava aula pra crianças, e isso aí já era o meu segundo ano de magistério, } 92 . \\
\text { Aí como eu já tava gostando das coisas novas, aí eu fui pra FDE, e aí, } \\
\text { imagina.. eu comecei a ser professora capacitadora. }\end{array}$ \\
\hline E2 & Nossa, que pulo, hein? \\
\hline Profa & $\begin{array}{l}\text { Que pulo! Só que daí o que é que acontecia? É que nem eu falava: a gente } \\
\text { bebia água na fonte, né? Aí eu tive palestra com a Thelma Vaz, com a } \\
\text { Emília Ferrero, com Mario Sérgio Portella, com Demerval Saviani, com o } \\
\text { João Vanderlei Geraldi, que aí eu me tornei fã dele. }\end{array}$ \\
\hline E2 & Mas aí você já tinha feito o curso de letras? \\
\hline Profa & Não, eu só tinha o Magistério. \\
\hline E2 & Ah, você só tinha o magistério! \\
\hline Profa & $\begin{array}{l}\text { Eu comecei ao contrário das outras pessoas, eu falo. Eu primeiro fui ter uma } \\
\text { vivência pra depois fazer o curso superior, o que eu acho que me ajudou. } \\
\text { Então aí eu comecei a ter envolvimento com esse pessoal, que foi um } \\
\text { investimento muito sério da FDE, muito sério mesmo, eu fiquei acho que } \\
\text { quatro anos fazendo curso, então eu aprendi muito! E o legal que era assim: } \\
\text { tudo o que a gente aprendia, na teoria, a gente tinha que aplicar na prática, } \\
\text { voltar pra FDE, expor sua prática, e ver mesmo... e aí, eu acostumei muito } \\
\text { com isso de rever a própria prática. E aí, lá na DE de Caieiras, eu fazia o } \\
\text { curso com a Lúcia, com a Ida, com o pessoal, e então era bem assim, a gente } \\
\text { lia psicogênese da língua escrita e transformava aquilo em prática de sala de } \\
\text { aula, com a orientação delas. }\end{array}$ \\
\hline E2 & E tinha que mostrar resultado. \\
\hline Profa & $\begin{array}{l}\text { E aí tinha que mostrar resultados, então aplicava tudo em sala de aula de } \\
\text { criança, de adulto e voltava pra elas. E aí o que tava bom elas falavam que } \\
\text { tava bom e o que não tava bom também não tava... a gente... então aí, foi aí } \\
\text { que eu acho que eu comecei, porque pra mim hoje, rever a própria prática é } \\
\text { algo natural, eu tenho que fazer isso toda aula, praticamente.. e aí depois eu } \\
\text { fui fazer curso de matemática.... aí eu vim fazendo e acho que o que me } \\
\text { ajudou, acho, não... eu tenho certeza, né? Foi assim, foi bem assim: o meu } \\
\text { começo de vida profissional, foi bem assim logo no primeiro ano. }\end{array}$ \\
\hline E2 & E como foi que você fez letras, depois? \\
\hline Profa & $\begin{array}{l}\text { Aí eu fiz letras... nossa, me formei em } 2001 \text { em letras! Entrei no curso de } \\
\text { letras acho que } 98,98 \text { ! É... quatro anos, } 98 \text { ! }\end{array}$ \\
\hline E2 & Mas você já trabalhou no ensino fundamental ou só de primeira a quarta? \\
\hline Profa & Ensino fundamental de quinta? \\
\hline E2 & Ensino fundamental dois... \\
\hline
\end{tabular}




\begin{tabular}{|c|c|}
\hline Profa & $\begin{array}{l}\text { Já.. eu dei aula de quinta ao ensino médio, eu comecei com a alfabetização } \\
\text { de adultos e de } 1^{\text {a }} \text { a } 4^{\mathrm{a}} \text {. }\end{array}$ \\
\hline E2 & De português... você deu aula de português? \\
\hline Profa & Não... era alfabetização mesmo! \\
\hline E2 & Não, quinta a oitava! \\
\hline Profa & quinta a oitava... \\
\hline E2 & Português? \\
\hline Profa & Português... mas aí já foi depois de 2001 isso. \\
\hline E2 & $\begin{array}{l}\text { E quando você trabalho de primeira a quarta assim, antes de todo esse } \\
\text { processo que a gente viveu aqui na escola, como que era seu contato com o } \\
\text { ensino de ciências? }\end{array}$ \\
\hline Profa & $\begin{array}{l}\text { Então, aí nessa minha trajetória de } 90 \text { até eu vim aqui, eu tive muito na área } \\
\text { de história, geografia, português e matemática. Ciências a gente sempre } \\
\text { falava que ciências era uma disciplina deixada de lado, nesses cursos que eu } \\
\text { fazia, e eu também quando eu ia fazer curso, porque eu me acostumei a fazer } \\
\text { curso. Mesmo quando a FDE me não dava eu ia fazer curso em outros } \\
\text { lugares. E eu sempre queria fazer na área de português, é claro, porque eu já } \\
\text { queria fazer faculdade de letras. Que eu comecei a fazer tradutora e } \\
\text { intérprete da Ibero e desisti, depois que eu fui fazer letras, então a minha } \\
\text { área sempre foi português. Então, o.. aqui no Cândido que eu fui ter contato } \\
\text { com ciências... com essa visão diferente. Eu tinha alguma coisa com a } \\
\text { professora chamada Regina também, lá em Morato, nessa época, porque aí, } \\
\text { tudo quanto é curso que aparecia eu fazia, e essa Regina eu conheci na FDE, } \\
\text { eu fiz algumas cosias com ela em Ciências, mas muito pouco. }\end{array}$ \\
\hline E1 & Mas você trabalhava de $1^{\mathrm{a}}$ a $4^{\mathrm{a}}$ então, antes de entrar aqui. \\
\hline Profa & $\begin{array}{l}\text { Trabalhava. Até } 98 \text { eu só trabalhei de } 1^{\mathrm{a}} \text { a } 4^{\mathrm{a}} \text { e alfabetização de adultos. } \\
\text { Alfabetização de adultos, acho que eu trabalhei, acho que } 6 \text { anos. Mas } \\
\text { alfabetização mesmo. Primeira série, adultos que não liam, não escreviam, e } \\
\text { de primeira a quarta. Eu geralmente pegava primeira, segunda série. }\end{array}$ \\
\hline E1 & Alfabetização Também. \\
\hline Profa & $\begin{array}{l}\text { Alfabetização. Aí com Ciências mesmo acho que foi aqui no Candido, que } \\
\text { teve laboratório, que teve tudo. }\end{array}$ \\
\hline E2 & $\begin{array}{l}\text { Mas é engraçado, né? Que nem você não tendo esse contato todo com ... } \\
\text { você chegou e abraçou os projetos da escola, né? Desde o primeiro ano que } \\
\text { você entrou, né? }\end{array}$ \\
\hline Profa & Porque eu já tinha isso. \\
\hline E2 & $\begin{array}{l}\text { Tem essa pré-disposição, né? Eu fico até surpresa com o que você diz, } \\
\text { porque ela chega, ela já entra num momento... }\end{array}$ \\
\hline Profa & Pra falar a verdade, eu sempre senti falta de... \\
\hline E2 & No primeiro ano aqui você deu aula do que mesmo? \\
\hline Profa & Quarta série... \\
\hline E2 & Quarta série, né? Que a gente trabalhou juntas desde o primeiro ano. \\
\hline Profa & $\begin{array}{l}\text { E quando eu vim pra prefeitura, eu senti muita falta disso, que eu vinha de } \\
\text { uma escola do estado, que eu nunca tinha dado aula na prefeitura, eu era } \\
\text { estado e particular, que eu fiquei } 8 \text { anos numa escola particular também. E o } \\
\text { estado, ele sempre deu muito curso, muito. No estado, não sei.. no tempo } \\
\text { que eu fiquei, só não fazia curso quem não queria. Eu não sei se eu que ia } \\
\text { muito atrás ou se tinha mesmo, entendeu? Então... se você pegar meus, } \\
\text { meus... certificados de quando eu entrei no estado, eu nunca fiquei sem }\end{array}$ \\
\hline
\end{tabular}




\begin{tabular}{|c|c|}
\hline & curso, nenhum ano, eu sempre fiz cursos. \\
\hline E1 & Eram cursos longos, assim? \\
\hline Profa & $\begin{array}{l}\text { Não, não.. .alguns eram... os maiores foram na área de alfabetização que } \\
\text { eram dois, três anos, era quase uma especialização, né? }\end{array}$ \\
\hline E1 & Ah, tá... \\
\hline E2 & $\begin{array}{l}\text { Então dá pra gente entender assim tranquilamente, essa sua predisposição } \\
\text { mesmo em abraçar os projetos, em participar de interagir nos grupos e tal, } \\
\text { mas com relação aos conteúdos de ciências de ciências mesmo? Porque a } \\
\text { sua formação é português, letras... }\end{array}$ \\
\hline Profa & Profa: é, letras... \\
\hline E2 & $\begin{array}{l}\text { Como é que você se vira, se virou com isso? Bem, né? Aparentemente bem, } \\
\text { né? }\end{array}$ \\
\hline Profa & $\begin{array}{l}\text { Então, aí... que vem a questão de ler, de pesquisar, que tinha aula que tinha } \\
\text { coisa que eu não sabia e eu pesquisava... e aí é lógico, aí entrou você... aí } \\
\text { entrou a parceria nesse momento. Porque eu não sabia nada e era nas } \\
\text { reuniões ou com a coordenadora ou na USP, que a gente tirava dúvida } \\
\text { mesmo... a parte que eu falava que eu gostava, que eu gosto, né? Da } \\
\text { sequência que eu trabalho, por exemplo, a parte de texto pra mim era } \\
\text { tranquilo, de ler, de criar aulas interessantes pra... aquilo pra mim era } \\
\text { tranquilo, mas o que entrava, o que era mesmo de ciências, aí que eu ficava } \\
\text { te perguntando, tirando dúvida... (risos)...e aprendendo com as crianças } \\
\text { também, né? Porque tinha coisa que a gente fazia, lembra né, que a gente } \\
\text { fazia? Que nem o barquinho, que a gente fez primeiro aqui no grupo de nós } \\
\text { professores, mas eu sempre ficava naquele: e eles? Eu quero ver eles... sabe, } \\
\text { ficava naquele ver para crer? E com eles as vezes me surpreendia mais, né? } \\
\text { Porque eles eram mais rápidos que a gente. }\end{array}$ \\
\hline E1 & $\begin{array}{l}\text { E o que te chamou atenção, assim, que você lembra, você falou por } \\
\text { exemplo, daquele seu aluno que teve aquele episódio, do choquito... }\end{array}$ \\
\hline Profa & É, isso é o mais marcante... \\
\hline E1 & $\begin{array}{l}\text { Mas aqui na escola, o que é que te chamou atenção para o ensino de } \\
\text { Ciências, foi alguma aula que você viu? Ou foi a... como se diz... a interação } \\
\text { no grupo? }\end{array}$ \\
\hline Profa & O meu, o que eu mais... com aluno, você está falando? \\
\hline E1 & Não, o que deu esse... esse desejo... \\
\hline E2 & O que mais te atraiu pra Ciências... \\
\hline E1 & é, o que te atraiu... pra participar do projeto. \\
\hline Profa & $\begin{array}{l}\text { Pra ciências? Acho que a vontade de aprender mesmo.... sinceramente, que } \\
\text { eu gosto, e eu acho... eu acho, não... sinceramente, a gente que é professor } \\
\text { de primeira a quarta, tem que saber de todas as áreas, né? }\end{array}$ \\
\hline E1 & $\begin{array}{l}\text { E quando você chega aqui na Cândido e encontra um laboratório de } \\
\text { Ciências, coisa que não tem em nenhuma outras escolas, como que foi isso } \\
\text { pra você? É que antes você não tinha muito contato com o ensino de } \\
\text { Ciências... isso te ... te... }\end{array}$ \\
\hline Profa & $\begin{array}{l}\text { Eu lembrei da escola particular, porque na escola particular tinha, só que eu } \\
\text { não ... mexia... porque era professor de ciências, era separado, né? Mas... aí } \\
\text { eu gostei, eu achei superinteressante, porque eu falei: eu não sei, em escola } \\
\text { pública eu nunca tinha visto, mesmo...e aí eu fiquei que nem os alunos, né? } \\
\text { Louca pra... você lembra o ano passado, que eu peguei o primeiro ano, eu } \\
\text { morria de vontade, né, E2? Eu falava assim... eu quero aplicar a sequência } \\
\text { no primeiro ano. }\end{array}$ \\
\hline
\end{tabular}




\begin{tabular}{|c|c|}
\hline E1 & $\begin{array}{l}\text { E na sala de aula, o que você acha que mudou a sua postura como } \\
\text { professora, você falou que já fez bastante curso, que já tinha essa questão do } \\
\text { questionamento, de ver o que o aluno sabia, mas com a sua chegada aqui no } \\
\text { Cândido, com todo esse contexto, você acha que mudou um pouco a sua } \\
\text { forma de... }\end{array}$ \\
\hline Profa & $\begin{array}{l}\text { O que mudou assim, eu vou falar na área de Ciências, mudou! Por que } \\
\text { assim, essa questão de trabalhar com o que a criança já sabe, de partir da } \\
\text { realidade deles, de fazer o levantamento de conhecimentos prévios, isso eu } \\
\text { já fazia... muito bem em português, em matemática, história, eu tinha essa } \\
\text { mania. Ciências pra mim parece que era assim: eu tinha que seguir o livro, } \\
\text { porque eu não dominava muito aquela área, né? Agora eu estou mais } \\
\text { metidinha, vamos dizer assim... }\end{array}$ \\
\hline E1 & Mais tranquila \\
\hline Profa & $\begin{array}{l}\text { Agora eu já consigo pegar mais um livro de ciências, né? Por exemplo: eu } \\
\text { vou começar com o corpo humano, então não vou começar do jeito que tá } \\
\text { aqui no livro... aí, eu acho que foi desse estudo, começar sempre com um } \\
\text { questionamento. Que aí eu falo, que eu sempre ligava pra Coord, ou } \\
\text { mandava e-mail... eu pensei, tal, em começar o conteúdo com essa } \\
\text { pergunta... que que você acha? Então isso agora eu faço mais na aula de } \\
\text { Ciências... de partir de um desafio, de uma pergunta, pra depois ir pro } \\
\text { conteúdo. }\end{array}$ \\
\hline E2 & E a experimentação? Você se sente desafiada a fazer experimentação? \\
\hline Profa & Eu me sinto... só precisava aprender mais experimentação... \\
\hline E1 & $\begin{array}{l}\text { E os alunos? Em relação ao seu papel como professora você passou a } \\
\text { perguntar mais, mas só no começo ou no meio, você acha, também? Por que } \\
\text { a gente olhando as suas aulas a gente percebe que você está sempre } \\
\text { levantando, pedindo, questionando, incentivando eles a falarem, olha, o que } \\
\text { é isso, o que é aquilo... }\end{array}$ \\
\hline Profa & $\begin{array}{l}\text { É, então... isso, essa prática, é como eu já falei... eu já tenha de outras áreas } \\
\text { a prática de sempre perguntar mais do que responder... mesmo porque } \\
\text { quando você vai vivendo em sala de aula, você vai aprendendo que as vezes } \\
\text { você faz uma pergunta, pensando que vão te dar uma resposta. Você já tem } \\
\text { isso, você prepara a aula você já tem isso mais ou menos... eu vou perguntar } \\
\text { isso, eles vão falar isso, eu vou partir pra aquilo e de repente vem uma } \\
\text { resposta do aluno que você não esperava e que até enriquece mais ainda a } \\
\text { sua aula. E aí, com esse grupinho que eu tava a gente sempre ficava } \\
\text { surpresa, né? Fazia uma pergunta e vinha umas respostas que você falava: } \\
\text { "meu Deus, da onde ele sabe isso?" Então é... isso de questionar, isso eu } \\
\text { sempre tive, e agora em ciências mais ainda, né? Na área de ciências... ainda } \\
\text { mais ciências que tem tanta coisa que eles se interessam... né? }\end{array}$ \\
\hline E2 & E que nunca mais ninguém apareça com a arca de Noé, \\
\hline Profa & A arca de Noé... (risos) \\
\hline E1 & Por que, vocês dizem....? \\
\hline Profa & $\begin{array}{l}\text { Porque a gente aprende, né? Porque no meio do questionamento... aí eu } \\
\text { comecei com um questionamento, e aí eu elaborei umas perguntas, né, } \\
\text { Coord.? O que eles sabiam de dinossauros, aí, que pergunta que eu tinha } \\
\text { feito? Ah! Saiu um questionamento se ... aí saiu do aluno a pergunta, se } \\
\text { existia homem junto com dinossauro. E aí, eu pedi pra eles pesquisarem isso } \\
\text { em casa mas não respondi na hora... Eu falei: então nós vamos pesquisar, } \\
\text { será que existia? Eu finjo que to na dúvida, né? Finjo que to na dúvida pra }\end{array}$ \\
\hline
\end{tabular}




\begin{tabular}{|c|c|}
\hline & $\begin{array}{l}\text { eles... será que existia ser humano junto com os dinossauros? Aí eu deixo } \\
\text { eles darem as respostas deles, né? Tinha aluno que achava que sim, que o } \\
\text { ser humano caçava os dinossauros, e o outro: não, o dinossauro era muito } \\
\text { grande, ia esmagar o ser humano. Ó, então faz assim, vocês vão pesquisar, } \\
\text { vão perguntar em casa, e amanhã a gente volta nesse assunto! E aí pra minha } \\
\text { surpresa, quem manda perguntar, né ... (risos)... um aluno veio com um livro } \\
\text { da religião dele, da religião, que a mulher provava, a autora provava que } \\
\text { eles entraram até na arca de Noé... Mas foi legal... }\end{array}$ \\
\hline E2 & E aí ela ligou pra mim à noite: Coord. o que que eu faço? \\
\hline Profa & Eu ria, né Coord. eu ria... \\
\hline E2 & Falei: deixa pra lá, Ana.. mais uma linguagem na sala de aula... \\
\hline Profa & $\begin{array}{l}\text { Aí eu brincava: não vou perguntar mais nada pra eles... ó, a gente fica } \\
\text { perguntando... mas foi legal, né? Tiramos de letra também, né, Coord.? Por } \\
\text { que o que eu mostrei pra eles que tudo... muitas coisas que a gente vai } \\
\text { estudar em ciências tem a visão religiosa, que é verdade... Pra tudo o que a } \\
\text { gente for estudar, criação do homem, vários assuntos, vai ter a visão } \\
\text { religiosa... só que religião, cada um defende a sua. Então eu vou ler o livro } \\
\text { que o fulano trouxe, o aluno, né? Muito interessante, levei o livro pra casa, } \\
\text { li... selecionei alguns trechos pra ler pra eles, porque tinha que ler! Porque } \\
\text { ele me cobrava, você vai ler meu livro? Li... separei as partes, li pra eles e } \\
\text { deixei bem claro que era a visão religiosa... e que na escola nós não íamos } \\
\text { discutir a visão religiosa, nós íamos discutir a visão científica! E ele aceitou } \\
\text { na boa, os alunos também, não tocaram mais no ... }\end{array}$ \\
\hline E2 & $\begin{array}{l}\text { Tanto que lá na, na... ele é o que mais defende que não tinha dinossauro na } \\
\text { Terra. }\end{array}$ \\
\hline Profa & Ele é o que mais defende, que não tinha... é engraçado... \\
\hline E1 & Vocês filmaram essas aulas também, não? \\
\hline Profa & Não... você filmou só a roda de conversa, né? \\
\hline E2 & Só a roda de Conversa... \\
\hline Profa & $\begin{array}{l}\text { Que foi surpreendente também, né? Que a gente fez... uma avaliação oral.. } \\
\text { eles aprenderam bem... achamos! }\end{array}$ \\
\hline E2 & $\begin{array}{l}\text { A gente sempre faz a roda de conversa no final ... durante o processo a } \\
\text { experimentação, tal... mas no final da sequência, pra variar a sequência, a } \\
\text { gente faz uma roda de conversa, o que a gente aprendeu com tudo isso, né? } \\
\text { E eles vão falando...e a gente aprendeu isso com a sequência, com as rodas } \\
\text { de conversa depois da experimentação... }\end{array}$ \\
\hline Profa & $\begin{array}{l}\text { É, isso eu não tinha, essa prática de roda de conversa, antes da sequência, eu } \\
\text { não tinha... eu tinha muito assim, de questionar, de conversar muito, eu falo } \\
\text { muito com os meus alunos... quando eu dei aula no ensino médio, eles } \\
\text { falavam pra mim: Ai, professora, a gente conversa tan... a aula que a gente } \\
\text { mais conversa é na sua... (risos) ... mas assim, que eu discutia, tudo o que eu } \\
\text { levava eu discutia... }\end{array}$ \\
\hline E1 & $\begin{array}{l}\text { Isso é uma forma de avaliar também, né? E tiveram outras coisas que } \\
\text { influenciaram a sua forma de avaliar em ciências, que influenciou um } \\
\text { pouco, de leituras, ou mesmo de vivência, das sequências... }\end{array}$ \\
\hline Profa & $\begin{array}{l}\text { Na forma de avaliar? Pra mim o que foi mais novo mesmo foi a roda de } \\
\text { conversa, porque o relatório eu já tinha prática }\end{array}$ \\
\hline E2 & Já fazia... \\
\hline Profa & Eu já fazia... \\
\hline E1 & Mas aqui na escola, também, antes? \\
\hline
\end{tabular}




\begin{tabular}{|c|c|}
\hline Profa & Aqui antes também \\
\hline E2 & Antes da Escola? Antes da Cândido? \\
\hline Profa & $\begin{array}{l}\text { Antes da escola.. .antes da escola já... a gente tinha... eu fazia, eu trabalhava } \\
\text { muito com texto coletivo antes de vir pra cá, isso eu aprendi em curso de } \\
\text { alfabetização... }\end{array}$ \\
\hline E2 & Em ciências... não? \\
\hline Profa & $\begin{array}{l}\text { Não, mas aí eu fazia em várias áreas... aí eu fazia, quando a gente aprendia... } \\
\text { mesmo que eu não trabalhasse ciências, dessa maneira nova que eu aprendi, } \\
\text { mas essa questão do relatório individual e da coisa do coletivo eu já tinha, só } \\
\text { que a gente chamava na época de texto coletivo... era diferente... }\end{array}$ \\
\hline E1 & Chama ainda, né? Não chama mais de texto coletivo? \\
\hline E2 & $\begin{array}{l}\text { Não, ainda faz texto coletivo mas agora o texto coletivo... aqui, aqui na } \\
\text { escola também, a gente faz o relatório e o texto coletivo, a grande novidade } \\
\text { realmente é você fazer a sala em círculo pra conversar, é você sentar pra } \\
\text { conversar com o aluno... }\end{array}$ \\
\hline Profa & Avaliar oralmente, né? \\
\hline E2 & $\begin{array}{l}\text { Ou seja, isso muda substancialmente, temporalmente a aula, porque é um } \\
\text { tempo que você dedica pra isso, né? Então... }\end{array}$ \\
\hline Profa & $\begin{array}{l}\text { É que na realidade quando a gente fala texto coletivo, ou quando você fala } \\
\text { relatório, você define o gênero... }\end{array}$ \\
\hline E2 & É, o relatório é uma escrita individual... \\
\hline Profa & $\begin{array}{l}\text { Por exemplo, nas outras aulas eu fazia um texto coletivo, a reescrita de um } \\
\text { conto, ou... o que aprendemos na aula de história sobre tal assunto? As vezes } \\
\text { não definia o gênero, a diferença é que isso daqui é relatório, é o gênero que } \\
\text { você define, o gênero textual. }\end{array}$ \\
\hline E1 & $\begin{array}{l}\text { Vou perguntar uma coisa mais... é... você acha que as leituras que você fazia } \\
\text { aqui mesmo, os textos, todo esse conhecimento teórico que vocês tinham ... } \\
\text { que você falou, por exemplo, na área de linguagem que te ajudou muito... } \\
\text { você acha que isso na área de ciências também ... porque vocês liam textos } \\
\text { aqui, chegavam lá vocês tinham teoria... e você acha que isso influenciou } \\
\text { bastante também na sua maneira de trabalhar, ou de pensar no ensino, por } \\
\text { exemplo... }\end{array}$ \\
\hline E2 & De que textos você está falando? \\
\hline E1 & De textos de ciências, de ensino aprendizagem, de alfabetização científica.. \\
\hline E2 & Textos pedagógicos... \\
\hline E1 & É, psicopedagógicos... \\
\hline Profa & Não os da sequência...os que a gente lia fora... \\
\hline E1 & Sim, da teoria de Ensino de Ciências, por exemplo... \\
\hline E2 & O texto da Sasseron sobre Alfabetização Científica, por exemplo... \\
\hline Profa & $\begin{array}{l}\text { Claro que ajudou bastante... o que foi o que eu falei... eu já tinha lido textos } \\
\text { teóricos em outras áreas, em ciências não... }\end{array}$ \\
\hline E1 & Sobre ensino de Ciências \\
\hline Profa & $\begin{array}{l}\text { É, sobre ensino de Ciências, foi muito legal, aquele que você me deu pra eu } \\
\text { ler, que era o que eu falava que eu queria, né? O que eles escrevem nas aulas } \\
\text { de Ciências }\end{array}$ \\
\hline E2 & Da Carla Oliveira... \\
\hline Profa & Da Carla, eu gostei bastante daquele texto... \\
\hline E2 & A gente leu o livro da Anna quase inteiro.. \\
\hline E1 & Conhecimento físico... \\
\hline
\end{tabular}




\section{Entrevista II - Professora e Entrevistadora}

E - Vamos continuar aquela conversa: Eu preciso tirar algumas dúvidas com você ainda sobre sua formação e história de vida. Tem algum professor do qual você se lembra que serviu de referência pra você na sua vida?

$\mathrm{P}$ - O que eu acho que eu pareço muito, mas não sei se o método, mas acho que o método também um pouco, o jeito dela, foi a minha professora do $3^{\circ}$ e $4^{\circ}$ ano primário, ele me deu aula dois anos seguidos. Eu acho que ela era diferente. Eu estudei na época do militarismo, no interior uma cidade pequena, e eu me lembro que ela fazia umas atividades muito diferentes com a gene. Começa assim, sentava menino e menina, que ela falava que homem tinha respeitar mulher e vice versa. (...)

$\mathrm{P}$ - E assim ela dava uns jogos, e eu não entendia quando eu era criança, mas hoje eu penso que aquela mulher deveria ser o máximo, né? É que eu não tinha maturidade.

$\mathrm{E}$ - mas tinha alguma coisa muito afetiva que lhe ligava a ela.

P. Isso. Ela era brava!. (...) Mas ao mesmo tempo que ela era brava, ela se impunha muito brava, mas ao mesmo tempo ela dava liberdade. Era um paradoxo, ao mesmo tempo em que ela era muito brava ela dava umas liberdades em sala de aula. Eu acho assim que ela ia pra dar aula mesmo pra gente. Nada de abracinhos e beijinhos. A gente tinha muita regra. (...) Ela dava muito jogo, pesquisa para casa, e eu me lembro que ela falava assim "se o Sr. Joao chegar na porta, todo mundo vai guardar essa folha e nós vamos pegar o livro tal. Olhe que interessante. E a gente pegava aquele livro. Era o diretor. E de vez em quando ele aparecia mesmo, tinha uma janelinha na porta da sala.

E - Quer dizer, ela dava a aula dela, do jeito dela

$\mathrm{P}$ - Escondido. Hoje eu imagino isso. E era tudo assim. Eu me lembro que ela dava pesquisas sobre o município. Eu descobrir o marco zero da cidade que eu morava ...(...)

E - Assistindo suas aulas o que que a gente percebe? Primeiro que você e consegue manter disciplina na classe

$\mathrm{P}$ - Eu acho que isso eu tenho de Dona Arlete.

E - Ela é a Dona Arlete. Isso é impressionante, você assiste a aula inteira, e as crianças, primeiro elas acompanham tudo que você faz, os seus gestos, elas seguem. Eu fíco olhando essa classe que está no $3^{\circ}$ ano hoje, essa classe foi sua no $2^{\circ}$ ano. Aquela roda de conversa que eu filmei, um dia que você tiver você deveria a assistir, pra você se ver mesmo, porque o que que eu estou pesquisando na roda de conversa? A mediação discursiva docente. O que que é isso? 'e tudo que você fala e faz ao mesmo tempo. O modo como você vai mediar a relação com as crianças, vai mediar a comunicação na sala. Então, eu percebo que as crianças não saem do ritmo. São 15 minutos de conversa, em 197 falas. Agora tem uma coisa, você pergunta muito. Por que você faz tantas perguntas? Não estou dizendo que é certo ou errado, é um modo de mediação, é um modo como você consegue controlar a disciplina, controlar o pensamento deles, controlar o que eles vão falar, né?

P- Eu não sei se eu vou saber responder explicar. Eu acho assim que quando eu pergunto é uma maneira de eu estar meio que avaliando o meu aluno pra ver o que ele sabe, quando é pra isso, o meu objetivo é um, quando eu quero levantar os conhecimento prévios deles, vamos supor, Eu faço um monte de perguntas com um objetivo, agora quando é uma roda de conversa pra encerrar o que eu trabalhei , aí eu quero saber se ele aprendeu mesmo 
aquilo. Então eu não gosto de eu dar a resposta, então eu fico me policiando muito, então eu não quero dar a resposta. Eu só dou a resposta em ultimo caso mesmo, quando eu vejo que ninguém deu.

E - Por exemplo, eu montei um padrão temático. Um padrão tem[ático daquela aula, daquela aula não, de três episódios. Eu não peguei a aula inteira, porque 197 falas é muita coisa. Eu peguei uns pedaços e aí eu montei um padrão temático. O padrão temático que se produz na aula. E tem um episódio que esse texto é produzido só com respostas das crianças. Você vai mediando com perguntas e confirmando as respostas delas, né, e vai montando o texto. Isso é muito interessante.

$\mathrm{P}$ - Esta semana eu trabalhei "A casa" do Vinicius de Moraes. Eles têm só 6 anos, mas eu queria que eles entendessem o poema, e no fim não tem casa. É uma atividade, em que a gente está trabalhado com livros e eles têm que fazer uma ilustração. Aí eu pensei, como é que eu vou fazer essas crianças entenderem que não tem casa? Eu não queria que na ilustração saísse uma casa, porque no poema não tem. Mas assim, é muito subjetivo para um aluno de 6 anos, enfim. Aí eu fiz tantas perguntas pra eles, até que eles chegaram a conclusão. Falei: "então, e se a gente tivesse que desenhar esse poema, fazer um desenho pra ilustrar?" E eles, "Nossa prô, já sei a gente não pode fazer casa nesse poema. "Nossa, na hora que eles falaram isso, eu achei a gloria. Aí eu pensei, eu atingi o meu objetivo. Assim, parece que é bobo, mas era uma interpretação difícil, subjetiva pra criança. Eu trabalho com eles falando que as vezes o poeta brinca com a gente, com os sentimentos, enfim,. Aí eles falaram, "ah professora, então eu já entendi, esse poeta está brincando com a gente. Apesar do poema chamar casa, não existe casa". Nossa, eu achei .... Mas porque eu vou, por que você acha isso, por que...

E - É, realmente, a pergunta é o seu principal modo de mediação.

$\mathrm{P}$ - eu acho que quando eu pergunto eu ajudo eles. Não sei se é certo, ou errado... Pela experiência, eu acho que eles chegam porque eu acho que eu vou instigando e a resposta de um ajuda o outro a pensar, não sei.

E - Já que você está falando disso aí, então complementa. Em que você acha que você contribui como professora para a educação das crianças?

$\mathrm{P}$ - Eu gosto de fazer eles estabelecerem relações, acho que é muito importante isso pra vida deles. Entender como que isso afeta isso, e isso. Por que eu acho que na vida as coisas não são compartimentadas, né? E na sala de aula também não. Então, por exemplo, se eu trabalhei esse poema, parece uma coisa boa e tal, eu não vou só pedir pra que eles desenhem e acabou. Acho que quando eu faço esse trabalho mais de instigar, de fazer eles irem a fundo e entender realmente. Eu acho que ajudo eles a ficarem pensando sobre as coisas. Por que isso é assim e não é assado? Por que não pode ser de outro jeito? Tornar o aluno uma pessoa questionadora, que tenha opinião. 


\section{Anexo III - Extratos dos encontros formativos citados na análise}

\section{Fórum I - 13 de maio de 2008}

\begin{tabular}{|c|c|c|}
\hline Turno & Sujeito & Falas transcritas \\
\hline 01 & Form. I & $\begin{array}{l}\text { Só pra gente ir esquentando como a gente fez as coisas, depois a gente } \\
\text { vai fazer a experiência do barquinho, que é a experiência chave desta... } \\
\text { Essa sequência tem duas experiências chaves: uma de física, que é a do } \\
\text { barquinho e a outra de biologia, que é da presa e do predador. Então, } \\
\text { nós vamos... biologia, ou ambiente, biologia tá muito próxima de } \\
\text { ambiente. Então nós vamos fazer hoje a de física, e dia } 27,27, \text { né? A } \\
\text { presa e o predador. Então nós vamos passar a palavra pra vocês, pra } \\
\text { ver como é que foi a sequência do submarino. }\end{array}$ \\
\hline 02 & Form. I & $\begin{array}{l}\text { Nem precisa, nem precisa, Coord. ... Nem precisa distribuir. É, } \\
\text { guarda... por que vamos fazer como aluno, aluno não vai receber isso... } \\
\text { Se não tem a resposta aí e tira toda graça, você entende? Como é que } \\
\text { foi a sequência do submarino, você ia começar a falar... }\end{array}$ \\
\hline 03 & Lia & $\begin{array}{l}\text { Então eu acho que eu posso falar um pouquinho da questão da quinta } \\
\text { série, né? Eu trabalho com o Cícero, né? Então, como a quinta é um } \\
\text { pouco mais dividida assim, né, em componentes, o Cícero trabalhou } \\
\text { assim uma parte assim mais geral do material. }\end{array}$ \\
\hline 04 & Form. I & O Cícero é de Ciências? \\
\hline 05 & & O Cícero é o professor de Ciências \\
\hline 06 & Form. I & E você de geografia? \\
\hline 07 & Lia & $\begin{array}{l}\text { E aí nós fomos entrando na parte de mapas, tivemos algumas } \\
\text { dificuldades na medida em que a escola tem alguns atlas só, né? Pra } \\
\text { trabalhar nas próprias carteiras, né? Tá meio assim defasado, mas já tá } \\
\text { comprando, atualizando o material. Então eles trabalharam assim a } \\
\text { primeira parte com o professor de Ciências, todo aquele } \\
\text { encaminhamento do material, e em geografia nós trabalhamos a } \\
\text { localização... e então, e assim, pra não bater, as pessoas trabalhando } \\
\text { exatamente os mesmos tópicos, os mesmos itens, o professor de } \\
\text { ciências veio trabalhando essa parte assim mais geral, e a gente foi } \\
\text { entrando nos mapas depois, né? Pra não estarmos todos falando no } \\
\text { mesmo assunto ao mesmo tempo, né? Então mais a parte de mapas, } \\
\text { depois a parte de geografia. }\end{array}$ \\
\hline 08 & Coord. & Você acha que a sequência ajudou? \\
\hline 09 & Lia & $\begin{array}{l}\text { Eu acho, melhor pra gente, né? Que aqui cada um na verdade deveria } \\
\text { estar trabalhando mais... e aí a gente tem que pensar em um material } \\
\text { mais adequado, de mapas que facilitassem... }\end{array}$ \\
\hline 10 & Coord. & Acessórios... \\
\hline 11 & & Isso, acessórios, pra gente ir trabalhando, né? \\
\hline 12 & Olga & Eu posso falar? \\
\hline 13 & Form. I & Pode...Você é quem? \\
\hline 14 & Olga & $\begin{array}{l}\text { Olga...E a minha é uma quarta. No começo eu senti muita dificuldade, } \\
\text { porque a minha sala é uma sala um pouquinho difícil. Porque é assim: } \\
\text { eles produzem, mas eles falam demais! }\end{array}$ \\
\hline 15 & Form. I & Gostoso \\
\hline 16 & Olga & É, mas as vezes atrapalha, dispersam muito, então tem que estar indo e \\
\hline
\end{tabular}




\begin{tabular}{|c|c|c|}
\hline & & $\begin{array}{l}\text { voltando, indo e voltando... mas, eles amaram fazer os mapinhas. Nós } \\
\text { fomos localizar os mapas e aí quando veio os mapas eles foram... eles } \\
\text { foram se adaptando. Muitos não conseguiam fazer, fazer o planisfério, } \\
\text { o continente, mar, tinha uns que pintavam tudo de azul, sabe? Mas eles } \\
\text { foram se adequando, se organizando e foi muito bom o trabalho com os } \\
\text { mares. }\end{array}$ \\
\hline 17 & Form. I & Mas isso não tá na sequência que a gente ... \\
\hline 18 & Várias & Tá... \\
\hline 19 & Olga & Tá... pra eles localizarem os mares... \\
\hline 20 & Form. I & Tá. Agora eu estou me lembrando. \\
\hline 21 & Olga & $\begin{array}{l}\text { Mas eu gostei muito deles terem trabalhado com os mapas, onde } \\
\text { estava, o oceano Atlântico, o oceano Pacífico. Isso pra eles, entre mar e } \\
\text { oceanos, era uma confusão só, então eu achei que isso deu pra eles, } \\
\text { sabe? Clarear as ideias, sabe? Entender o que é que é uma coisa... }\end{array}$ \\
\hline 22 & Form. I & Clarear os conceitos... \\
\hline 23 & Olga & $\begin{array}{l}\text { Isso, clarear os conceitos, isso mesmo! Porque eles tem uma coisa de } \\
\text { se localizarem, uma dificuldade muito grande de se localizarem, de } \\
\text { saber, ó, o Brasil tá aqui, tá na América. Nós fomos, nós partimos do } \\
\text { mapa mundi, depois partimos pras Américas, encontramos o Brasil... e } \\
\text { depois os oceanos, onde ficavam os oceanos e localizamos mares aqui, } \\
\text { e então, isso ajudou muito também. E a sequência também foi muito } \\
\text { boa! } \\
\text { E outra coisa que meus alunos fizeram também, foi muito proveitoso, } \\
\text { foi a pesquisa sobre os peixes e nós fizemos essas ... as fichas a pedido. } \\
\text { E foi muito.. também achei muito proveitoso também, porque eles } \\
\text { foram lá e pesquisaram, quais eram os peixes que viviam nas águas } \\
\text { mais profundas. Eu falei: eu não quero família de não sei o que, não } \\
\text { quero isso. Porque é quarta série, então eu não quero isso aí, eu quero } \\
\text { uma linguagem bem sucinta... Em que oceano a gente encontra? Qual o } \\
\text { habitat dele? O que é que ele come, qual a sua habitação, então eles } \\
\text { gostaram também de fazer as fichas. }\end{array}$ \\
\hline 24 & Coord. & Quer dizer a sequência inteira foi... \\
\hline 25 & Lia & $\begin{array}{l}\text { Foi boa, foi boa, teve bons resultados. E agora com o feedback da } \\
\text { avaliação que a gente fez, me surpreendeu! }\end{array}$ \\
\hline 26 & Coord. & Avaliação? \\
\hline 27 & Olga & $\begin{array}{l}\text { Nós fizemos, né? Ela fez... quartas-séries. Até nós montamos uma } \\
\text { juntos, né? E eles colocaram. Lá tá bem claro! }\end{array}$ \\
\hline 28 & Form. I & E dá pra tirar um Xerox dessa avaliação pra gente ter? \\
\hline 29 & Coord. & $\begin{array}{l}\text { Eu vou fazer o seguinte: eu vou dar um caderno pra cada criança, e nós } \\
\text { vamos montar uma espécie de um dossiezinho... um caderno pra cada } \\
\text { uma... com as impressões dele... }\end{array}$ \\
\hline 30 & Olga & $\begin{array}{l}\text { Nossa, e comenta muito, que pra ele subir ele tem que estar leve, pra } \\
\text { ele descer ele tem que estar pesado... }\end{array}$ \\
\hline 31 & Form. I & $\begin{array}{l}\text { Eu gostaria muito, porque nós nunca fizemos uma avaliação assim, nós } \\
\text { nunca trabalhamos em uma escola, entende? A gente ia pra testar, pra } \\
\text { fazer as coisas , mas nunca numa escola, que testava, que tinha que } \\
\text { fazer avaliação, que tinha que dar nota... Então é muito interessante. }\end{array}$ \\
\hline 32 & Olga & $\begin{array}{l}\text { Eu pensei: ai, meu Deus... a gente trabalhou tanto! Mas foi assim, } \\
\text { surpreendente! É claro que não é assim um } 100 \text { por cento. Não é isso. } \\
\text { (risos) }\end{array}$ \\
\hline
\end{tabular}




\begin{tabular}{|c|c|c|}
\hline 33 & Form. I & É claro! \\
\hline 34 & Olga & $\begin{array}{l}\text { Não é? Não é isso... mas a maioria eu fiquei contente! Todo aquele } \\
\text { trabalho valeu a pena, graças a Deus! }\end{array}$ \\
\hline 35 & Form. I & E vocês, fizeram também? Que fez? \\
\hline 36 & Coord. & Todas... \\
\hline 37 & Sofia & Eu fiz outra atividade... eu fiz o da água. \\
\hline 38 & Form. I & Mas quem mais deu o submarino? \\
\hline 39 & Mara & $\begin{array}{l}\text { Eu estou dando... Mas não tenha pressa, eu não terminei ainda... Ontem } \\
\text { eu falei pra ela assim: olha, a gente não tá falando da diferença de } \\
\text { mares e oceanos, a profundidade, tudo... e aí eles já querem saber do } \\
\text { peixe que não tem olho, que vive lá no fundo... }\end{array}$ \\
\hline 40 & Form. I & Ah, eu também... \\
\hline 41 & $\begin{array}{l}\text { Professor } \\
\text { as }\end{array}$ & Risos \\
\hline 42 & Mara & $\begin{array}{l}\text { E aí você tem que parar tudo o que você está falando, e aí eles querem } \\
\text { saber, mas como que faz isso, mas como que faz aquilo, como que faz } \\
\text { aquilo... E aí você traz no laboratório de informática, mostra, pesquisa, } \\
\text { e aí, dos mares, eles queriam saber porque que era mar negro... } \\
\text { Trouxemos na sala de informática, foram pesquisar, fizeram um painel } \\
\text { na sala, tá lá pendurado, quer dizer... a menina falou que o mar } \\
\text { vermelho era por causa da bíblia, "e não, porque é assim, assim, assim, } \\
\text { recebe esse nome" (representando um estudante falando)... então eles } \\
\text { tem muita curiosidade! Então a gente fica atrasado nas coisas, então eu } \\
\text { não terminei ainda, estou terminando... }\end{array}$ \\
\hline 43 & Form. I & Não, não tem data, não tem nada... \\
\hline 44 & Mara & Ah, tá... \\
\hline 45 & Form. I & $\begin{array}{l}\text { Ah, é por isso que a gente gostaria, gostaria muito de filmar a classe, } \\
\text { pra ver o que desperta nos alunos, a finalidade disso é despertar } \\
\text { mesmo... chama enculturação! Introduzir os alunos, o livro inteiro vai } \\
\text { ter o nome de introduzir os alunos no Universo das Ciências, a } \\
\text { coleção... então.. esse é uma atividade e uma posição muito importante } \\
\text { pra gente, porque ele desperta, porque sempre o que os livros textos } \\
\text { fazem é chato, não desperta nada daquilo... Então se desperta, pra } \\
\text { gente é muito importante! É isso que a gente quer, por isso que a gente } \\
\text { tá testando todas as atividades antes de por na praça. }\end{array}$ \\
\hline 46 & Mara & $\begin{array}{l}\text { É, porque tem criança que fala assim: nossa, agora é aula de... Mas } \\
\text { agora não... você faz isso, faz aquilo e aí quando bate o sinal pra ir } \\
\text { embora, eles falam: ah, mas já acabou? Já acabou! Porque quando vc } \\
\text { faz uma atividade que eles gostam... né? rápido! }\end{array}$ \\
\hline 47 & Verônica & $\begin{array}{l}\text { A minha sala, eu achei que eles ficaram muito presos na atividade de... } \\
\text { né? Que a gente estava falando, né? Da curiosidade dos mares, né? } \\
\text { Então... eu achei que eles ficaram muito presos ao submarino mesmo, } \\
\text { né? Então... essa aula que a Coord. gravou, tem muita dificuldade, } \\
\text { porque eu não sabia responder, só que eu também mostrei pra eles que } \\
\text { eu também to aprendendo! Anotei na lousa todas as dúvidas, falei: } \\
\text { então nós vamos procurar outro texto e aí eu até pensei: Coord., eu vou } \\
\text { ter que pesquisar, né? Mas aí eu li a história do submarino, então eu } \\
\text { pulei a sequência... }\end{array}$ \\
\hline 48 & Coord. & $\begin{array}{l}\text { Ela deu o texto inicial e como eles fizeram muitas questões ela pulou } \\
\text { pro último texto... }\end{array}$ \\
\hline
\end{tabular}




\begin{tabular}{|c|c|c|}
\hline 49 & Form. I & Pro último texto, é... \\
\hline 50 & Verônica & Porque eu falei: não vai dar pra esperar, né? Então eu trouxe... \\
\hline 51 & Form. I & Não, não... tem que ver na hora que eles querem! \\
\hline 52 & Verônica & $\begin{array}{l}\text { E acho que foi o dia que eu gravei, se não me engano... e aí eu tava na } \\
\text { história do submarino, eu aprendi um monte de coisas com ele e a } \\
\text { maioria das respostas, a gente falou que ia deixar aí... assim, o que o } \\
\text { texto não respondeu, a gente deixou pra perguntar e ver... "Não } \\
\text { professora, eles tem GPS hoje"... }\end{array}$ \\
\hline 53 & Form. I & $\begin{array}{l}\text { Risos... Por mais que a gente queira ser bacana, a gente sempre tá } \\
\text { atrasado! }\end{array}$ \\
\hline 54 & Mara & É, ficou famoso esse negócio do GPS... \\
\hline 55 & Verônica & $\begin{array}{l}\text { E aí eu trouxe um submarino pra eles, que eu vi que eles ficaram } \\
\text { vidrados no submarino. Aí eles adoraram e eu trouxe a história daquele } \\
\text { submarino que eu tinha trazido, nada pra aprofundar... pra eles } \\
\text { saberem, né? O que era um submarino de guerra, que era o que tinha } \\
\text { sido falado, Aí eles colocaram algumas coisas que eram interessantes } \\
\text { que eles colocaram também: que o submarino é interessante pra } \\
\text { pesquisar o fundo do mar. }\end{array}$ \\
\hline 56 & Olga & Eles falaram também! \\
\hline 57 & Verônica & $\begin{array}{l}\text { E aí eles também estão nessa de quererem saber sobre os peixes, aí eles } \\
\text { também tão pesquisando, essa parte de fazer a pesquisa sobre os } \\
\text { peixes, nós também estamos pesquisando, nós estamos fazendo na } \\
\text { internet! Tão descobrindo também que nem tudo o que eles veem na } \\
\text { internet traz resposta, né? As vezes tem que procurar em outro lugar... } \\
\text { né? Então também tá... E outra coisa que eu quero fazer agora com } \\
\text { eles, mas aí também é mais minha área, de língua portuguesa, é um } \\
\text { mapa pessoal que a gente fez... }\end{array}$ \\
\hline 58 & Form. I & O que é isso? Mapa pessoal? \\
\hline 59 & Verônica & Eu chamo de mapa, mas acho que nem tem muito assim... \\
\hline 60 & Coord. & É mapa conceitual, coisas, frases que as crianças se lembram... \\
\hline 61 & Verônica & $\begin{array}{l}\text { Eu coloquei assim: zonas oceânicas, zona fótica, zona afótica. Aí eu } \\
\text { percebi que pra eles, na elaboração, aí tem a questão de elaboração do } \\
\text { texto. Eles tem que saber explicar o que eles aprenderam melhor... Aí } \\
\text { vou fazer a correção com eles. E aí outra coisa que tem na sequência, } \\
\text { que é, que são as cruzadinhas, pra eles elaborarem as perguntas. Eu } \\
\text { achei que eles se saíram muito bem nessas duas atividades, então eu } \\
\text { tenho que retomar e ajudá-los porque tem outras aqui... mas no geral, o } \\
\text { que tá ligado ao fundo do mar, o oceano e o submarino eles tão assim... }\end{array}$ \\
\hline 62 & Form. I & Vocês vejam, a necessidade que eu tenho de gravar 3, 4 pessoas... \\
\hline 63 & Várias & Cada sala. \\
\hline 64 & Form. I & $\begin{array}{l}\text { Cada professora é uma professora, que cada sala? Cada professora é } \\
\text { uma professora... E o que a gente tá querendo, lógico, como eu falei, eu } \\
\text { quero ver se o texto tá bom, se a sequência tá bom... mas o que a gente } \\
\text { quer como subsídio e a gente pode sim, como é que ela fez pros alunos } \\
\text { adorarem e ver e como é que ela fez pros alunos mudarem a } \\
\text { linguagem, pra ver os mapas e aprender, né? Quer dizer: a gente pode... } \\
\text { com } 3 \text { quatros de dois, analisar o que cada um pode fazer pra ... o que } \\
\text { eu preciso é três, quatro pra ver se o texto funciona, pra centrar minha } \\
\text { visão nos alunos, não no professor, pra cada uma das atividades, apesar } \\
\text { de três, quatro, tipo de aulas diferentes, o que é ótimo, os alunos saem }\end{array}$ \\
\hline
\end{tabular}




\begin{tabular}{|c|c|c|}
\hline & & $\begin{array}{l}\text { bem, os alunos falam, os alunos discutem, eles se processam na } \\
\text { enculturação. }\end{array}$ \\
\hline 65 & Coord. & $\begin{array}{l}\text { E tem outra coisa, professora, que é importante pra filmagem, que a } \\
\text { gente vai aprendendo com isso, é que vocês também querem pesquisar, } \\
\text { não querem? Todos querem fazer mestrado! Todos querem fazer } \\
\text { mestrado. E a gente filmando a aula, fica como um banco de dados da } \\
\text { escola, porque todos querem pesquisar também. }\end{array}$ \\
\hline 66 & Form. I & $\begin{array}{l}\text { E eu to conversando com ela, to à disposição pra dar uma orientação } \\
\text { nas pesquisas. Certo? Eu gostaria muito de ver como é que faz aquilo } \\
\text { que vocês contaram lá, certo? }\end{array}$ \\
\hline 67 & Coord. & É, escrita coletiva... \\
\hline 68 & Form. I & $\begin{array}{l}\text { Escrita coletiva, que eu nunca vi na vida, certo? Desculpa, eu nunca dei } \\
\text { aula pra primeiro grau... }\end{array}$ \\
\hline 69 & Coord. & É tão normal... \\
\hline 70 & Form. I & $\begin{array}{l}\text { Não é normal, filha... não é assim, analisado, discutido, posto, provado, } \\
\text { que é uma coisa bacana, então todo mundo faz por fazer, mas o que a } \\
\text { gente quer mostrar é que algumas atividades ensinam. E como é que } \\
\text { ensinam? Então... a minha visão é nos alunos. }\end{array}$ \\
\hline 71 & Coord. & $\begin{array}{l}\text { É, contar pra criança com o texto científico, como é que ... isso todo } \\
\text { mundo pode fazer. }\end{array}$ \\
\hline 72 & Form. I & $\begin{array}{l}\text { Pode, e veja: o meu pesquisar, quando eu falo o meu pesquisar, parece } \\
\text { que é meu, mas não é! Graças a Deus to já aposentada, então não } \\
\text { preciso pesquisar mais nada, mas é trabalhar junto! Com outras } \\
\text { pessoas! }\end{array}$ \\
\hline 73 & Mara & $\begin{array}{l}\text { Eu acho que é interessante, sim, porque chama bastante a atenção } \\
\text { deles, né? Quando é uma coisa muito longa, é cansativo, né? Até a } \\
\text { Coord. chegou e me apressou um pouco: vamos encerrar essa semana, } \\
\text { porque a gente vai... porque quando a gente tinha bastante tempo, } \\
\text { comecei a mudar: Olha, amanhã todo mundo traz caderno do projeto, } \\
\text { então a gente vai trabalhar no projeto. Então tem que terminar essa } \\
\text { semana, então foi uma coisa assim meio corrida! Porque senão ele não } \\
\text { ia aprender nem submarino mais, né? Mas pelo contrário, eles traziam } \\
\text { e trabalhavam, período todo, né? Quero dizer, todo período até eu } \\
\text { conseguir terminar. E a pesquisa eles fizeram, a pesquisa, né, dos } \\
\text { peixinhos... e quanto a parte do painel, que tinha que no final fazer um } \\
\text { painel, eu vi que nas pesquisas quase nenhuma tinha profundidade. E aí } \\
\text { eu peguei assim que agora, vocês pegam todos os trabalhos que vocês } \\
\text { tem, que vocês pesquisaram, né? Agora vocês vão pés... é, entrar na } \\
\text { pesquisa, para saber qual o lugar que eles ficam, se ficam no mais raso, } \\
\text { mais fundo. E a gente já tinha passado, falando sobre profundidade, e } \\
\text { eles entraram no laboratório de informática e geralmente eles falam: } \\
\text { prô, posso jogar? Tal... mas dessa vez eles entraram e falaram: 'Prô, a } \\
\text { gente já pode fazer a pesquisa aqui?’. Porque muitos não tem, né? E aí } \\
\text { eles correram, foram pra sala, pegaram o caderno e voltaram e } \\
\text { pesquisaram cada um em um computador... }\end{array}$ \\
\hline 74 & Coord. & $\begin{array}{l}\text { É porque a gente precisa de um prazo, né? Se não também acaba tudo } \\
\text { se repetindo, porque tem o barquinho pela frente, que de uma maneira } \\
\text { ou de outra volta ao mesmo assunto de novo, né? }\end{array}$ \\
\hline 75 & Form. I & É, são sequências de sequências... \\
\hline 76 & & E eles nunca reclamaram... Nossa, de novo isso, não! Nunca, eles não \\
\hline
\end{tabular}




\begin{tabular}{|c|c|c|}
\hline & & falaram isso. Em momento nenhum, eu não ouvi ninguém reclamando. \\
\hline 77 & Coord. & Não, eles gostaram mesmo! \\
\hline 78 & Olga & $\begin{array}{l}\text { Porque é o mesmo assunto, mas a gente trata cada vez com um enfoque } \\
\text { diferente! Você tá dando uma sequência, então eles tão entendendo, } \\
\text { eles tão cada dia mais aprendendo conceitos diferentes sobre o mesmo } \\
\text { assunto. Não é? }\end{array}$ \\
\hline 79 & Mara & [faz sim com a cabeça] \\
\hline 80 & Form. I & Ele é o professor que deu na quinta série. \\
\hline 81 & Coord. & $\begin{array}{l}\text { É, o Cícero. E ele é de português, de Geografia, e de Ciências... e } \\
\text { você? }\end{array}$ \\
\hline 82 & & Eu sou de artes. \\
\hline 83 & Cícero & $\begin{array}{l}\text { Eu fiz com uma sala só, né? A gente trabalhou alguns pontos só, o que } \\
\text { dava pra trabalhar dentro do ... }\end{array}$ \\
\hline 84 & Form. I & Você só deu o do barquinho, só deu o do submarino? \\
\hline 85 & Cícero & O do submarino, com as tabelas, os conceitos... \\
\hline 86 & Lia & $\begin{array}{l}\text { É, e infelizmente a gente tem o tempo limitado. A gente tem aqueles } 45 \\
\text { minutos e só, acaba! }\end{array}$ \\
\hline 87 & Form. I & $\begin{array}{l}\text { É porque a sequência, a gente tá querendo ver agora aqui pra oitava, } \\
\text { mas a gente quer ver assim....Tem mais alguém que vai falar? Senão a } \\
\text { gente passa... [professoras murmuram] Tá! Então a gente vai passar pra } \\
\text { começar a... }\end{array}$ \\
\hline 88 & Coord. & Vou lá fora ver o que é esse barulho... \\
\hline 89 & Form. I & $\begin{array}{l}\text { Bom, depois ela volta... pior que os nossos... Bom: nós vamos começar } \\
\text { a sequência do barquinho. A sequência do barquinho tem o desafio } \\
\text { matemático antes. Pra quê? Justamente pra unir a matemática, com a } \\
\text { ciência, com o português, quer dizer: da primeira à quarta então é um } \\
\text { trabalho integral! Então eu queria, é um desafio bem simples, mas é } \\
\text { assim: } \\
\text { Três homens querem atravessar o rio e pesam } 60,65 \text { e } 80 \mathrm{~kg} \text {. Como } \\
\text { devem proceder para atravessar o rio, sem afundar o barco? O barco } \\
\text { possui no máximo 130kg. [escreve na lousa]. } \\
\text { Eu queria, a gente pede pra utilizar o caderno pra registrar a solução e } \\
\text { escreva e desenhe a solução. Isso é o padrão pra todas as atividades: } \\
\text { escreva e desenhe, quer dizer: eles tem uma outra linguagem da } \\
\text { ciência, então eles tem que aprender a trabalhar com ciências, então... } \\
\text { ele vai desenhar a Ciência, ele vai começar a desenhar o fenômeno e } \\
\text { escrever, escrever é essencial. Eu não vou dar todas as atividades pra } \\
\text { vocês, mas eu gostaria que vocês fizessem a atividade, em } 5,10 \\
\text { minutinhos pra resolver o problema. Aqui, } 2,4 \text {. Aqui, } 1,2,3,4 . . . \\
\text { [dividindo os grupos]. }\end{array}$ \\
\hline Pausa & Grupo & Professoras trabalham em grupo para resolver o problema. \\
\hline 90 & Form. I & $\begin{array}{l}\text { Olha, então todos já fizeram! Essa atividade tem esse objetivo: é dar } \\
\text { risada, é ver, é saber que consegue fazer, certo? É entender as diversas } \\
\text { possibilidades. Vocês fizeram várias hipóteses, certo? A Hipótese dela } \\
\text { é: não dá, não dá, } 80 \text { não pode ir sozinho... } 80 \text { não pode ir com } \\
\text { nenhum. Quando ela diz: } 80 \text { não dá com nenhum, tá na cara, então } \\
\text { quer dizer: estão, pensando, que } 80 \text { tem que ficar sozinho sempre! } \\
\text { Então, essa frase dela: } 80 \text { não dá, } 80 \text { com } 60 \text { dá mais de } 130 \ldots 140,80 \\
\text { com } 60 \text { dá } 140,80 \text { com } 65 \text { dá mais de } 130 \text {. Então, as hipóteses que são } \\
\text { hipóteses que são tiradas fora, certo? Então tirar fora uma hipótese é a }\end{array}$ \\
\hline
\end{tabular}




\begin{tabular}{|c|c|c|}
\hline & & $\begin{array}{l}\text { coisa mais importante da ciência, então essa... essa brincadeira, vamos } \\
\text { dizer, essa brincadeira, isso tá na internet de todos os jeitos possíveis, } \\
\text { isso é importantíssimo pra todos os raciocínio dos alunos! Mas esse é } \\
\text { só pra brincar, pra ver, pra dar risada, pra... tá... Mas a aula também é } \\
\text { feita pra dar risada, né? Isso também é importante! Agora nós vamos } \\
\text { fazer ... }\end{array}$ \\
\hline 91 & Coord. & $\begin{array}{l}\text { Mas tem alguma coisa também por trás... o raciocínio matemático que } \\
\text { está incluso aí... }\end{array}$ \\
\hline 92 & Form. I & É... \\
\hline 93 & Sofia & É, acho que pra gente.... eles tem umas sacadas que a gente não tem! \\
\hline 94 & Form. I & $\begin{array}{l}\text { Filha, aluno não tem medo de errar... então é o grande desafio, eles não } \\
\text { tem medo de errar, então não tem ... a gente se auto policia muito! Se } \\
\text { auto policia perante a todos, não quer ferir a imagem, a auto imagem } \\
\text { da gente, então é muito mais difícil... }\end{array}$ \\
\hline 95 & Sofia & Pra adulto! \\
\hline 96 & Form. I & $\begin{array}{l}\text { É muito mais difícil trabalhar com professor do que trabalhar com o } \\
\text { aluno, certo? Mas se vocês conseguiram em } 10 \text { minutos, vocês não } \\
\text { levaram nem 10, levaram menos... Os alunos vão levar muito menos, } \\
\text { mas eles vão escrever, isso leva... Por que? Porque eles vão desenhar, } \\
\text { então eles vão desenhar os barquinhos, vão desenhar as pessoas, a } \\
\text { gorda, a magra... ou seja, eles vão começar a observar a natureza e vão } \\
\text { por no papel, certo? E vão por no papel, e isso é essencial pra Ciência. } \\
\text { Quando eles forem trabalhar com a Biologia, a biologia toda vai ter } \\
\text { desenho. A Física vai ter desenho mais especializados, mas eles vão } \\
\text { começar a pegar, e vão escrever, que é essencial, pra expor, pra relatar } \\
\text { as escritas. Trabalhar com escrita também é uma delícia, quem quiser } \\
\text { trabalhar com escritas das crianças, eu tenho toda uma... eu... uma } \\
\text { orientanda tem toda a bagagem teórica, que pra: entre, a narração, a } \\
\text { exposição, se os alunos conseguem chegar ao porquê... lógico que ele } \\
\text { chega ao porquê, ele chega ao porquê porque quando eles fazem o } \\
\text { porquê dá certo, é lógico: } 80 \text { com } 60 \text { dá } 140 \text {. Mas será que eles põe } \\
\text { isso no papel? }\end{array}$ \\
\hline 97 & Coord. & $\begin{array}{l}\text { Uma coisa que eu percebo de fazer com elas, no grupo é que antes elas } \\
\text { tem uma dificuldade de argumentar... Por que? Aí elas repetem muitas } \\
\text { vezes o como fez, mas não argumentar.... que acho que o papel da } \\
\text { gente... }\end{array}$ \\
\hline 98 & Form. I & $\begin{array}{l}\text { Mas isso é só no fim da aula, não queira... porque esse é o trabalho que } \\
\text { a gente tá fazendo, que é o trabalho da Lúcia, que é o que a gente tá } \\
\text { vendo... que pra chegar a argumentar, ele tem que passar muito bem } \\
\text { pelo como. Porque quando você faz uma pergunta do porquê e ele } \\
\text { responde o como, é porque ele ainda tá na fase do como. Tem que } \\
\text { deixar mais tempo como, quer dizer tem que deixar mais tempo a } \\
\text { descrição, a tomada de consciência, pra depois ele conseguir, porque o } \\
\text { porquê é a relação entre as variáveis, certo? E se ele ainda não tá } \\
\text { consciente das variáveis, ele não chegam... mas o que nós estamos } \\
\text { falando, viu, Coord., é que muitos alunos chegam ao porque, falam o } \\
\text { porquê, argumentam, mas na hora de escrever não põe no papel, aí é } \\
\text { outra coisa difícil, outra luta, outra coisa difícil, que a gente tem que } \\
\text { estudar muito pra saber como começar... Agora a gente tem que... }\end{array}$ \\
\hline 99 & Ides & Professora: eu posso falar uma coisinha? \\
\hline
\end{tabular}




\begin{tabular}{|c|c|c|}
\hline 100 & Form. I & Lógico \\
\hline 101 & Ides & $\begin{array}{l}\text { Eu sou professora de Língua Portuguesa, a partir da } 5^{a} \text { série. É isso } \\
\text { mesmo a questão da argumentação pra eles, isso que acontece na } \\
\text { questão da argumentação em todas as séries, porque você só argumenta } \\
\text { quando você conhece aquilo. Desde pequeno você fala: Mãe, eu quero } \\
\text { isso... mas porque é que você quer isso? Então ele justifica porque ele } \\
\text { quer aquilo. Ele vai justificar bem, se ele sabe o que ele quer muito } \\
\text { aquilo, então ele vai encontrar n argumentos pra convencer a mãe } \\
\text { daquilo... É igual a questão da argumentação mesmo... ele só vai } \\
\text { argumentar se ele conhece bem aquilo que ele tá fazendo. Aí ele vai } \\
\text { poder explicar porque ele chegou a este fato. }\end{array}$ \\
\hline 102 & Form. I & $\begin{array}{l}\text { Pois é, por isso mesmo a criança escreve... a gente vê isso muito bem, } \\
\text { escreve muito melhor na aula de ciências, quando ele passa pela } \\
\text { atividade de conhecimento físico, do que nas outras aulas. Nós já } \\
\text { fizemos essa experiência em termos de comparar com a mesma } \\
\text { professora, a aula que tinha toda uma sequência de atividades, com a } \\
\text { aula de português, que ele tinha que escrever e tem... a gente nem } \\
\text { conseguiu por no papel, porque não tinha escrita na aula de português. } \\
\text { Certo? Como a professora dava tudo prontinho, eles não tinham } \\
\text { argumentação: não era deles o conteúdo! Pra eles escreverem, tem que } \\
\text { ser deles o conteúdo. Eles tem que saber, escrever... }\end{array}$ \\
\hline 103 & Ides & Dominar. \\
\hline 104 & Form. I & $\begin{array}{l}\text { Dominar... Pra escrever. Mesmo assim, que a gente tá com } \\
\text { interrogação, mesmo assim, porque que a gente pesquisando... porque } \\
\text { mesmo assim, ele, que fala, que escreve que argumenta, não escreve } \\
\text { até a argumentação? É um desafio pra escola, mas a gente só tem o } \\
\text { desafio, a hora que a gente tem todas as variáveis mais estudadas, é um } \\
\text { desafio... a gente tem que estudar como professora de português, mas a } \\
\text { gente não é professora de português, não sou nem de primeiro grau. } \\
\text { Então, a outra atividade, depois que os alunos escreveram, viram tudo, } \\
\text { tem outra a atividade, que é a atividade do barquinho que é essa que } \\
\text { nós vamos fazer... Então, vocês vão distribuir pra cada grupo... ah, } \\
\text { espera um pouquinho! Limpa a mesa, senão vai cair tudo água aí... } \\
\text { Então olha! Nós vamos distribuir pra cada grupo uma ... três quatro, } \\
\text { cinco papéis .. pêra, deixa fazer o papel, pra depois o problema... Tá... }\end{array}$ \\
\hline 105 & & Professoras se movimentam pela sala, organizando os grupos... \\
\hline 106 & Sandra & Mas isso aqui não vai afundar, professora? \\
\hline 107 & Form. I & $\begin{array}{l}\text { Calma... senta, não são só seus alunos não sentam... Então! Cada grupo } \\
\text { vai receber uma bacia com água, papel alumínio e várias, várias } \\
\text { arruelas. Eu vou dar mais arruelas até! O problema é: vocês vão ter que } \\
\text { construir um barquinho que leve o máximo de arruelas possível! Você } \\
\text { vai ter ... eu vou dar muitas arruelas. Você vai ter que levar o máximo } \\
\text { de arruelas possíveis. Cada um tem, mas se vocês quiserem e precisar } \\
\text { mais papel, vai falando aí... }\end{array}$ \\
\hline 108 & Lia & Cada uma vai fazer um barco, não? \\
\hline 109 & Form. I & $\begin{array}{l}\text { Não... cada uma pode fazer um barco, vocês são livres, querida... cada } \\
\text { uma fazer um barco ou um barco pro grupo. }\end{array}$ \\
\hline $\begin{array}{l}\text { Todo } \\
\mathrm{S}\end{array}$ & & $\begin{array}{l}\text { Todos os professores trabalham na construção do barquinho, não é } \\
\text { possível ouvir a discussão em um grupo apenas. }\end{array}$ \\
\hline 110 & Form. I & Agora, eu gostaria que vocês contassem, como que vocês conseguiram \\
\hline
\end{tabular}




\begin{tabular}{|c|c|c|}
\hline & & resolver o problema. \\
\hline 111 & Sandra & $\begin{array}{l}\text { Ah, aqui no nosso grupo nós discutimos, eu achava que nós fossemos } \\
\text { usar todos os papéis poderia ficar um barco pesado por causa da } \\
\text { profundidade da água, aí tentamos... ela tentou de um jeito, eu tentei de } \\
\text { outro, a Helena de outro, e aí, no fim, acabou-se vendo que um barco } \\
\text { maior que poderia usar todos os papéis, caberia mais peso possível, o } \\
\text { maior número de arruelas. }\end{array}$ \\
\hline 112 & Form. I & E vocês, como é que fizeram? \\
\hline 113 & Mara & O nosso da maneira tradicional. \\
\hline 114 & Sofia & Primeiro que nós fizemos afundou... \\
\hline 115 & Mara & $\begin{array}{l}\text { Afundou... aí a gente colocou mais peso... E aí, o grupo, né? O homem } \\
\text { lá... não.. a mulher já tinha falado: ó, tem que ser aquele que carrega } \\
\text { barco, que carrega carro, um monte de carro... e aí, como já olhamos } \\
\text { pros outros grupos e fizemos o barco... }\end{array}$ \\
\hline 116 & Form. I & Vocês usaram mais de uma folha? \\
\hline 117 & Inês & Não usamos, usamos uma folha. \\
\hline 118 & Form. I & E aí? [alguém mais comenta sobre ter o olhado o grupo do lado] \\
\hline 119 & Form. I & $\begin{array}{l}\text { Não, não é feio... O colar na escola é feio porque você vai ver... na } \\
\text { Ciência, ver o que os outros fazem, não é feio! Qualquer mestrado, } \\
\text { qualquer curso, qualquer trabalho científico, você começa o trabalho, } \\
\text { mostrando o que todo mundo fez. Então: ver o raciocínio do outro e } \\
\text { entender o raciocínio do outro, e quando você olha e você entende, e } \\
\text { vai ver e vai fazer, então... isso é uma coisa possível, possível e muito } \\
\text { desejável. Pra que a gente vai ver? O colar é quando você copia e não } \\
\text { sabe o que está fazendo. Você sabia, quando olhou pra ela, entendeu o } \\
\text { que estava fazendo? }\end{array}$ \\
\hline 120 & Coord. & $\begin{array}{l}\text { Eu entendi. Na verdade eu tentei fazer igual com aquele outro, mas } \\
\text { ficou muito feio e muito pequeno. Assim, eu fiz uma coisa realmente ... } \\
\text { A minha intenção era essa: fazer o que eles tinham feito, né? }\end{array}$ \\
\hline 121 & Form. I & $\begin{array}{l}\text { E vocês? Como é que fizeram? Ah, tava ali, mas explica você! Explica } \\
\text { com as suas palavras... }\end{array}$ \\
\hline 122 & Lia & $\begin{array}{l}\text { Eu fiquei esperando elas fazerem, né? Pra ver o que ia dar... eu ia fazer } \\
\text { outro, elas falaram: não se não vai acabar o papel, então eu fiquei } \\
\text { olhando. E aí eu fiquei só raciocinando ali e vi que o da Nil ia dar } \\
\text { melhor mesmo, aí eu falei: tem que ser um grandão mesmo, senão não } \\
\text { vai dar. }\end{array}$ \\
\hline 123 & Attie & $\begin{array}{l}\text { Eu também, tava observando, porque o pequenininho virou, né? O da } \\
\text { Nil foi o que se aproximou mais, quando eu ia falar: vai ter que usar } \\
\text { mais folhas pra fazer um maior, foi quando nós olhamos o da vizinha e } \\
\text { era exatamente isso. }\end{array}$ \\
\hline 124 & Form. I & $\begin{array}{l}\text { E vocês? Como é que vocês fizeram? O que que vocês pensaram? } \\
\text { Como é que vocês fizeram? }\end{array}$ \\
\hline 125 & Olga & $\begin{array}{l}\text { As meninas que falaram.... Eu... pensei no barquinho, mas eu não sabia } \\
\text { fazer barquinho e aí as meninas falaram: vamos equilibrar, vamos } \\
\text { tentar fazer com uma folha. Então nós tentamos de folha em folha, pra } \\
\text { colocar as arruelas, né? Pra ver se afundava ou não... aí ela falou assim: } \\
\text { e se a gente dobrar a borda? }\end{array}$ \\
\hline 126 & Verônica & Porque eu via que reto não dava certo... \\
\hline 127 & Olga & $\begin{array}{l}\text { É, porque cada vez que a gente ia colocar, uma hora afundava de um } \\
\text { lado... Aí a Celinha falou assim: vamos colocar todas as arruelas fora e }\end{array}$ \\
\hline
\end{tabular}




\begin{tabular}{|c|c|c|}
\hline & & vamos dobrar as bordas, foi aí que nós colocamos e aí ficou. \\
\hline 128 & Lia & $\begin{array}{l}\text { Nós equilibramos fora primeiro, que na medida em que vai se } \\
\text { colocando uma arruela, pesa mais de um lado do que de outro... Então } \\
\text { elas bem distribuídas fora, e foi colocada a forminha, de um bolo } \\
\text { assim... }\end{array}$ \\
\hline 129 & Verônica & $\begin{array}{l}\text { Sabe o que eu acho, eu estava comentando com elas e acho que o meu } \\
\text { raciocínio não tá tão fora... o que pode acontecer com os alunos é eles } \\
\text { se prenderem à palavra barco e quererem construir um barco. Né? } \\
\text { Então talvez... }\end{array}$ \\
\hline 130 & Form. I & Mas é bom que aconteça... todo mundo, o normal \\
\hline 131 & Verônica & Pensar no barco... \\
\hline 132 & Form. I & $\begin{array}{l}\text { É pensar no barco... mas porque é importante falar barco e não falar } \\
\text { balsa? Porque o erro é muito importante! O erro de fazer o barco e o } \\
\text { barco virar, isso dá, dá margem a um raciocínio diferente. Se vocês } \\
\text { fizerem balsa e eles já fizerem balsa, eles nunca vão pensar que só tem } \\
\text { um tipo de barco... então, a necessidade de fazer o barco, eles fazem } \\
\text { barco, cai o barco e aí depois a gente pode passar o vídeo, você trouxe } \\
\text { o vídeo, né? }\end{array}$ \\
\hline 133 & Coord. & Já, tá prontinho... \\
\hline 134 & Form. I & $\begin{array}{l}\text { E o barco, pra ver que as crianças fazem o barco, eles tem a } \\
\text { dificuldade, eles... não dá... por que? Pra depois responder o porquê. } \\
\text { Por que deu certo? [professora começa a falar] Pera um pouquinho... }\end{array}$ \\
\hline 135 & Verônica & $\begin{array}{l}\text { Porque daí, acho que porque nós acertamos rápido, é porque nenhuma } \\
\text { de nós sabe fazer barco (risos). Era uma habilidade, né? [muitos risos] } \\
\text { Dá um medo. E aí depois vem mais algumas... [risos]... Mas depois } \\
\text { acabou ajudando. }\end{array}$ \\
\hline 136 & Ides & $\begin{array}{l}\text { Provavelmente eles vão fazer a pergunta: "professora, qualquer tipo de } \\
\text { barco?" Que nós não fizemos esse tipo de pergunta, né? O aluno pode } \\
\text { perguntar! }\end{array}$ \\
\hline 137 & Form. I & Nós fizemos sim... \\
\hline 138 & Ides & $\begin{array}{l}\text { Porque nós não pensamos, quando falou assim: a voz de comando, o } \\
\text { aluno se prende muito a o que o professor fala ao pé da letra, né? } \\
\text { Nossa equipe pensou neste tipo de barco, ninguém pensou noutro tipo } \\
\text { de barco, né? }\end{array}$ \\
\hline
\end{tabular}


Fórum I - 27/05/08

\begin{tabular}{|c|c|}
\hline TURNO & FALAS \\
\hline 1 & $\begin{array}{l}\text { Form. II - Do barquinho nós filmamos tudo num único momento, o experimento } \\
\text { do barquinho, como e o porquê e a escrita e então demora mais mesmo foi cerca } \\
\text { de } 1 \text { hora e meia }\end{array}$ \\
\hline 2 & $\begin{array}{l}\text { Coord. - depois tem o estudo coletivo que a gente quer realmente fazer um } \\
\text { trabalho com a professora Anna com a escrita coletiva }\end{array}$ \\
\hline 3 & $\begin{array}{l}\text { Mara - A escrita Coletiva é demorada, até você levantar tudo, organizar tudo isso } \\
\text { o texto vai tempo. }\end{array}$ \\
\hline 4 & $\begin{array}{l}\text { Form. II - Agora eu não sei como vocês estão pensando em dividir essas duas } \\
\text { aulas. Porque uma dica que eu dou e o que eu peço para vocês fazerem, é que na } \\
\text { primeira aula, se for dividir em duas, na primeira aula ser a experimentação e a } \\
\text { discussão do como e o porquê. Porque se jogar a discussão do como e do porque } \\
\text { para o outro dia }\end{array}$ \\
\hline 5 & $\begin{array}{l}\text { Coord. - Não a gente nunca faz o relatório no outro dia, o relatório é no mesmo } \\
\text { dia, a gente acha que tem que ser tudo no mesmo dia. }\end{array}$ \\
\hline 6 & $\begin{array}{l}\text { Form. II - E joga para o outro dia só a escrita coletiva, é isso que eu estou entendo } \\
\text { desse esquema? }\end{array}$ \\
\hline 7 & $\begin{array}{l}\text { Coord. Ou no mesmo dia, vai depender do tempo das crianças, a gente já resolve } \\
\text { tudo }\end{array}$ \\
\hline 8 & $\begin{array}{l}\text { Mara- A escrita coletiva eu costumo fazer no final do trabalho.Porque no caso da } \\
\text { experimentação ele já vai fazer o relatório e vai colocar o porque e o como, } \\
\text { naquele relatório individual. Eu faço assim não sei como as meninas fazem. A } \\
\text { proposta do texto coletivo e o fechamento do final do ciclo, terminou aquilo, faz } \\
\text { o fechamento e descobre que elenca tudo que viram, que descobriram e então a } \\
\text { gente fecha. }\end{array}$ \\
\hline 9 & Coord.- Eu acho que a conclusão do submarino, logo após o submarino, você fez \\
\hline 10 & Mara - Não, mas nós fizemos a conclusão só para fixação do emergir e submergir \\
\hline 11 & Coord. - Isso, no caso do barquinho também, se for fazer, mas vocês quem sabem \\
\hline 12 & $\begin{array}{l}\text { Form. II - Eu não estou entendendo, essa conclusão já é o texto escrito ou foi à } \\
\text { discussão }\end{array}$ \\
\hline 13 & $\begin{array}{l}\text { Mara - não, nós fizemos a atividade aqui, eles fizeram o relatório e surgiu à } \\
\text { dúvida do emergir e do submergir, quando era um e quando era outro, então na } \\
\text { sala tiramos as dúvidas, as crianças colocaram o que eles achavam e fizemos um } \\
\text { textinho. Mas uma coisa básica, acho que de } 5 \text { linhas, nem isso }\end{array}$ \\
\hline 14 & Sandra - e foi coletivo \\
\hline 15 & $\begin{array}{l}\text { Mara - e foi coletivo, tirou a dúvida daquilo que era submergir e emergir e } \\
\text { passamos para frente }\end{array}$ \\
\hline 16 & $\begin{array}{l}\text { Form. II - Porque na atividade do submarino tinha essa questão dos nomes que } \\
\text { poderiam complicar um pouco, agora o barquinho, eu acho que o ponto central } \\
\text { que certamente os alunos vão pegar é a questão do tamanho do barco, não lembro } \\
\text { quando vocês fizeram, eu não estava aqui quando vocês fizeram com a Anna, mas } \\
\text { barco influenciando na quantidade de peças que você pode carregar e, além disso, } \\
\text { a distribuição dessas peças, os alunos vão falar muito disso, de que é necessário } \\
\text { distribuir por toda área do barco feito, porque senão ele afunda também. Eles até } \\
\text { chegam a comentar que se colocarem tudo junto o meio, pode ser um barco muito } \\
\text { grande, o barco vai afundar. Então esses são os dois pontos principais que precisa } \\
\text { aparecer na discussão, os alunos certamente vão falar disso, mas se não falar, cês }\end{array}$ \\
\hline
\end{tabular}




\begin{tabular}{|c|c|}
\hline & deem um jeito de fazer perguntas que levem eles a colocar isso \\
\hline 17 & Mara - Em relação à distribuição e ao tamanho? \\
\hline 18 & Form. II - A distribuição e forma da massa e o tamanho do barco. \\
\hline 19 & Mara - Não complica, eu entendo, mas eles \\
\hline 20 & $\begin{array}{l}\text { Form. II - Eles não vão falar em distribuição e forma, mas vão dizer que } \\
\text { precisava distribuir direitinho, precisava equilibrar, eles vão falar em equilíbrio, } \\
\text { equilíbrio é uma palavra que vem a tona com essa atividade, porque eles } \\
\text { percebem que se coloca em uma ponta do barco uma pecinha é necessário colocar } \\
\text { na outra ponta a pecinha igual }\end{array}$ \\
\hline 21 & Coord. - É aquela... Volume e massa \\
\hline 22 & $\begin{array}{l}\text { Form. II - É, volume eles não vão falar, eles vão falar tamanho do barco e as } \\
\text { pecinhas que distribuíram e a necessidade de lidar com o equilíbrio para o } \\
\text { barquinho não afundar, é isso que vai aparecer. E pra gente é mais que suficiente, } \\
\text { que é essa relação que faz com que o barquinho se mantenha na água. }\end{array}$ \\
\hline 23 & Mara $-\ldots$ \\
\hline 24 & $\begin{array}{l}\text { Form. II - Sempre tem um. Porque é engraçado, eles começam a construir o barco } \\
\text { de dobradura, mas quando eles percebem que aquele cone no centro atrapalha a } \\
\text { distribuição das peças, eles começam a achatar o cone, só nisso de achatar o cone } \\
\text { já vem o formato de uma assadeira. }\end{array}$ \\
\hline 25 & Coord. - Sapateira, assadeira, eles falam no filme \\
\hline 26 & Form. II - Saboneteira, \\
\hline 27 & Coord. - Sapateira não, saboneteira \\
\hline 28 & $\begin{array}{l}\text { Form. II - Então vão vir coisas desse tipo, não se inquietem porque vai ter um que } \\
\text { vai começar a fazer o barco tipo balsa }\end{array}$ \\
\hline 29 & $\begin{array}{l}\text { Mara - Na hora de assistir o filme, nós estávamos com alguns professores do } \\
\text { nível 2, um de matemática e uma de história e no filme fica bem claro que a } \\
\text { professora comanda e some, ele não interfere em mais nada, tanto que eles } \\
\text { tentam, tentam, tentame não tem nenhuma interferência do professor. Naquele } \\
\text { momento é só comanda mesmo? }\end{array}$ \\
\hline 30 & $\begin{array}{l}\text { Form. II - O que a gente dá de conselhos para vocês fazerem, deixou o problema } \\
\text { claro para eles e nesse caso o problema é construir com a folha dada um } \\
\text { barquinho, que colocado na água consiga carregar o maior numero de pecinhas } \\
\text { sem afundar, esse é o problema. A professora que pode não aparecer no vídeo, eu } \\
\text { não me lembro agora, acredito que não apareça mesmo, ela anda pelos grupos } \\
\text { vendo se todos entenderam o problema, mas ela não dá dica de como deve ser } \\
\text { feito esse barco, então vai acontecer sim, da sala toda fazer o barquinho } \\
\text { dobradura primeiro. }\end{array}$ \\
\hline 31 & Rose - Esse é o primeiro momento? \\
\hline 32 & Form. II - Sim \\
\hline 33 & Ângela - nós percebemos que teve uma sala que demorou muito. \\
\hline 34 & $\begin{array}{l}\text { Form. II - Eu tenho experiência de uma aula dessas que fomos dar e eu tinha } \\
\text { recortado quatro rolos de papel alumínio e não deu, depois tivemos que cortar } \\
\text { mais e no próprio vídeo a professora ficou lá atrás recortando mais folhas, porque } \\
\text { demora mesmo até eles chegarem à coisa }\end{array}$ \\
\hline 35 & Rose - Não pode dar dica, então espera eles fazerem \\
\hline 36 & $\begin{array}{l}\text { Form. II - O que você pode fazer é: eles te chamam e falam: a professora eu fiz } \\
\text { este barquinho, mas carregou pouca peça. }\end{array}$ \\
\hline 37 & Rose- e aí? \\
\hline 38 & Form. II - Esse é o único tipo de barquinho? \\
\hline
\end{tabular}




\begin{tabular}{|c|c|}
\hline 39 & Coord. - Não pode inventar outro que carregue mais? \\
\hline 40 & $\begin{array}{l}\text { Mara - É porque no filme não fica claro. A professora da a comanda, não se } \\
\text { todos na hora que assistimos o filme entenderam assim. A professora da a } \\
\text { comanda e acabou, então, porque eu sou muito ansiosa e fico naquela expectativa } \\
\text { de "oh, meu filho vamos logo" }\end{array}$ \\
\hline 41 & Form. II- Não, a professora faz isso é que o filme é... \\
\hline 42 & Mara - Ah! Porque nós falamos assim: e agora, qual é a postura do professor? \\
\hline 43 & $\begin{array}{l}\text { Sandra - eu achei que tinha aqueles cortes, aquelas montagens, eu falei pra ela, } \\
\text { mas está muito assim ... }\end{array}$ \\
\hline 44 & $\begin{array}{l}\text { Form. II - O que a professora não faz e eu peço para vocês não fazerem é chegar e } \\
\text { dar uma dica do formato do barco. Você pode pedir para ele, será que não tem } \\
\text { outro jeito de barco? }\end{array}$ \\
\hline 45 & Rose - esse é o único tipo de barco? \\
\hline 46 & $\begin{array}{l}\text { Form. II - E depois quando eles já tiverem feito um barco maior e tiverem } \\
\text { dificuldade em distribuir as peças, fazer alguma pergunta que leve eles a perceber } \\
\text { que também é necessário equilibrar as peças na hora de colocar, não pode colocar } \\
\text { tudo no centro. }\end{array}$ \\
\hline 47 & $\begin{array}{l}\text { Verônica - Mas eu acho que aí e mais fácil, depois que eles acham o formato por } \\
\text { conta própria, eu acho que o equilíbrio é mais fácil deles perceberem }\end{array}$ \\
\hline 48 & $\begin{array}{l}\text { Mara - Porque quando eles estão fazendo aquele barquinho de dobradura, eles } \\
\text { também já começam a equilibrar }\end{array}$ \\
\hline 49 & $\begin{array}{l}\text { Coord. O desafio matemático já dá uma dica importante para eles, que é distribuir } \\
\text { as pessoas dentro do }\end{array}$ \\
\hline 50 & Mara - Mas eu acho que o desafio matemático vai levar certo tempo \\
\hline 51 & $\begin{array}{l}\text { Sandra - minha sala eu acho também, a da Mara é mais ágil, mais dinâmica, eu } \\
\text { penso que na minha sala vá demorar um pouco mais }\end{array}$ \\
\hline 52 & Coord. A gente tem que ter paciência \\
\hline 53 & Sandra - mas é por conta da ansiedade mesmo \\
\hline 54 & $\begin{array}{l}\text { Form. - Eles ficaram primeiro com, eles tinham um papel xerocado o titulo do } \\
\text { desafio e tudo bonitinho, alguns tentaram começar fazendo conta de dividir, algo } \\
\text { desse tipo... No final da terceira serie, mas eles começaram a resolver de fato } \\
\text { quando eles pegaram o estojo para fazer cada, para representar cada um dos } \\
\text { homens e aí então o negocio deixa de ser abstrato e passa a ser concreto, e í eles } \\
\text { viam como poderiam fazer outras formas. A professora foi no mesmo sentido, } \\
\text { passou pelos grupos, vendo se todos eles tinham entendido o problema. }\end{array}$ \\
\hline 55 & $\begin{array}{l}\text { Coord. Seria o caso de colocar um áudio no grupo para pegar algumas } \\
\text { discussões, porque a filmadora não pega todos os grupo, esse é um problema da } \\
\text { filmagem da aula, põe um mp3 nos grupos para pegar algumas discussões. }\end{array}$ \\
\hline 56 & Form.II - Pode ser também \\
\hline 57 & $\begin{array}{l}\text { Mara - É porque vai ter grupos que vai sair coisas interessantes, até eles } \\
\text { chegarem nem consenso }\end{array}$ \\
\hline 58 & $\begin{array}{l}\text { Coord. - Uma coisa também que pega é difícil você ter aquela mobilidade pra } \\
\text { você fazer o trabalho em grupo e depois a conversa com outra organização de } \\
\text { espaço e o submarino mesmo, o que a gente fez? Nós arrumamos o laboratório } \\
\text { assim, as cadeiras em circulo e as mesas soltas eles faziam as atividades em pé e } \\
\text { depois eles sentavam e isso deu certo, mas o barquinho não dá para fazer em pé, } \\
\text { então vamos ter que ter paciência para organizar e desorganizar e organizar de } \\
\text { novo }\end{array}$ \\
\hline 60 & Coord. - Mas aí a gente tira toda a água, tira tudo e faz um... \\
\hline
\end{tabular}




\begin{tabular}{|c|c|}
\hline 61 & $\begin{array}{l}\text { Form. II - Isso que a Coord. está dizendo é de extrema importância, porque, } \\
\text { temos percebido que quando não se desmonta o grupo, o pequeno grupo e não faz } \\
\text { uma roda geral a discussão não se torna muito efetiva, ela pode ser para um } \\
\text { aluno, de um grupo, porque ele acaba sendo a cabeça daquele grupo e ele vai falar } \\
\text { e o resto já se sente como se tivesse contribuído, porque no meu grupo já falaram, } \\
\text { agora quando está ali na roda todo mundo é dono de si, então se a professora } \\
\text { pediu para eu dar minha opinião, eu tenho que dar minha opinião, é uma nuance } \\
\text { diferente, então esse cuidado para organizar a sala primeiro, para eles fazerem as } \\
\text { atividades e depois disso organizados, desmembrar os grupos para cada um dar a } \\
\text { sua opinião é importante. }\end{array}$ \\
\hline 62 & $\begin{array}{l}\text { Coord. - Mas o desafio matemático, a gente acha que, estava conversando com } \\
\text { elas ontem, elas acham que pode deixar mesmo para elas fazerem em dupla }\end{array}$ \\
\hline 63 & Form. II - A gente fez até em grupo de 4 e 5 \\
\hline 64 & Coord. - Eu acho que quanto mais crianças mais fácil fica \\
\hline 65 & $\begin{array}{l}\text { Mara - Poderíamos montar então grupinhos, quartetos, porque o desafio é } \\
\text { complexo e depois que falei que ia ser dupla, eu achei que é meio complicado } \\
\text { porque se é um aluno que tem um pouco mais de dificuldade, não tem uma tirada } \\
\text { rápida, vai demorar muito }\end{array}$ \\
\hline 66 & Sandra - ele não vai contribuir com o colega, vai sobrecarregar realmente \\
\hline 67 & Mara - em quatro a possibilidade de ele solucionar é mais rápida \\
\hline 68 & Coord. - É a chance de ter maiores discussões \\
\hline 69 & $\begin{array}{l}\text { Form. II - no começo eles são meio tímidos, eles ficam cada um tentando } \\
\text { resolver sozinho, mas logo eles já estavam conversando entre si e quando o } \\
\text { primeiro grupo resolveu, todos os outros já estavam no mesmo caminho, porque } \\
\text { também percebem o vizinho está fazendo e já engata naquela ideia. }\end{array}$ \\
\hline 70 & Coord. - Você vai fazer a... Do submarino quando? \\
\hline 71 & Mara - essa semana \\
\hline 72 & Coord. - Essa semana quando? \\
\hline 73 & $\begin{array}{l}\text { Mara - agora complicou porque eu não sei se a reunião vai ser sexta-feira, } \\
\text { complica a vida da gente se for na sexta-feira }\end{array}$ \\
\hline 74 & Sandra - Alguém falou alguma coisa? \\
\hline 75 & $\begin{array}{l}\text { Coord. - mas sexta-feira pelo que eu entendi quando faz na sexta não é para todo } \\
\text { mundo, é só para os pais que tem filhos com dificuldade. }\end{array}$ \\
\hline 76 & $?-\ldots$ \\
\hline 77 & Coord. - Com a coordenadora \\
\hline 78 & Rose - ah! Com a coordenadora? \\
\hline 79 & Coord. Não é com vocês não \\
\hline 80 & Verônica - Mas a gente não está sabendo \\
\hline 81 & $\begin{array}{l}\text { Mara - Provavelmente quinta-feira, porque quarta eu termino tudo que tenho que } \\
\text { falar, }\end{array}$ \\
\hline 82 & Coord. Na quinta... \\
\hline 83 & Mara - então deixa para sexta, só que aí faz o desafio na segunda \\
\hline 84 & Coord.- Hoje a Verônica e a Ângela começam? \\
\hline 85 & Ângela - Não a minha é amanhã, porque hoje tem informática e educação física \\
\hline 86 & Coord. - Por isso que eu estranhei quando você falou que seria hoje \\
\hline 87 & Ângela - não, é amanhã. \\
\hline 102 & Mara - E no dia foi comentado se nós podíamos falar embarcação \\
\hline 103 & Verônica - quando você fala barco \\
\hline 104 & Mara - Ele vai sempre se reportar a um barquinho \\
\hline
\end{tabular}




\begin{tabular}{|c|c|}
\hline 105 & $\begin{array}{l}\text { Verônica - Aquele barquinho de dobradura, a embarcação ele já pode sacar que } \\
\text { pode ser uma balsa. }\end{array}$ \\
\hline 106 & Form. II - Pode ser, pode ser \\
\hline 107 & Verônica - Eu acho pelo menos \\
\hline 108 & $\begin{array}{l}\text { Mara - ficou uma dúvida e gostaríamos de saber se, no caso, na hora da comanda, } \\
\text { podemos falar uma embarcação }\end{array}$ \\
\hline 109 & $\begin{array}{l}\text { Form. II- Ou um tipo de barco, eu não sei se embarcação é uma palavra do } \\
\text { conhecimento deles }\end{array}$ \\
\hline 110 & Ângela - qual? \\
\hline 111 & Mara- Embarcação \\
\hline 112 & $\begin{array}{l}\text { Form. II - Quando for propor a atividade a atividade do barquinho, elas estão } \\
\text { dizendo para ao invés de pedir para eles construírem um barco, construir uma } \\
\text { embarcação }\end{array}$ \\
\hline 113 & Ângela - Ah! Sim \\
\hline 114 & $\begin{array}{l}\text { Mara - Porque quando você fala em barco, eles vão logo construindo um } \\
\text { barquinho de papel }\end{array}$ \\
\hline 115 & $\begin{array}{l}\text { Ângela - È eu falei isso no dia que eu observei, porque a palavra barco, eu acho, } \\
\text { que eles vão pensar no barco de dobradura }\end{array}$ \\
\hline 116 & $\begin{array}{l}\text { Coord. - Mas isso tudo bem, porque eles avançam no pensamento deles. Se eu } \\
\text { falasse um tipo de barco? }\end{array}$ \\
\hline 117 & $\begin{array}{l}\text { Ângela - Eu falei, eu pensei por experiência própria, porque o dia em que nós } \\
\text { fomos fazer o nosso grupo só tentou outra embarcação porque ninguém sabia } \\
\text { fazer o barquinho. E então falamos: já que ninguém sabe fazer o barquinho } \\
\text { vamos tentar outro? }\end{array}$ \\
\hline 118 & $\begin{array}{l}\text { Form. II - Essa atividade se torna interessante também, porque à medida que eles } \\
\text { vão fazendo outros tipos de barco, eles vão percebendo de maneira mais clara } \\
\text { essa relação de tamanho, quando eles começam fazendo o pequeno, eles } \\
\text { percebem que o pequeno não carrega muita peça, mesmo se eu distribuir muito } \\
\text { bem a peça }\end{array}$ \\
\hline 119 & $\begin{array}{l}\text { Coord. - E é importante para eles aquele erro deles fazerem o barquinho de } \\
\text { chapeuzinho, colocar a arruela e ele virar }\end{array}$ \\
\hline 120 & Rose - Ver ele cair, ele virar \\
\hline 121 & $\begin{array}{l}\text { Coord. -É importante para que eles percebam que aquela hipótese não foi legal e } \\
\text { que eles têm que inventar outra, eu acho que é um processo }\end{array}$ \\
\hline 122 & $\begin{array}{l}\text { Mara - Mas é isso que eu estou falando, nós somos muito ansiosas, nós queremos } \\
\text { até facilitar muito né, que é o nosso erro. }\end{array}$ \\
\hline 123 & $\begin{array}{l}\text { Ângela - Ontem a hora que eu vi o filme fiquei um pouco mais tranquiila, porque } \\
\text { eu percebi que teve uma sala que demorou muito }\end{array}$ \\
\hline 124 & Sandra - È verdade, eu pensei a minha vai se encaixar \\
\hline 125 & Form. II - Elas demoram mesmo \\
\hline 126 & Ângela - Eu fiquei mais tranquila \\
\hline 127 & $\begin{array}{l}\text { Form. II - É muito comum, ali naquele vídeo do barquinho, uma das professoras } \\
\text { que aplicou a Luciana, é uma colega nossa do laboratório. E ela disse que o } \\
\text { pessoal da filmagem estava aflito também, porque as crianças não chegavam e } \\
\text { eles queriam que chegassem logo. }\end{array}$ \\
\hline
\end{tabular}


Fórum II - 27/08/2008

\begin{tabular}{|c|c|}
\hline 1 & 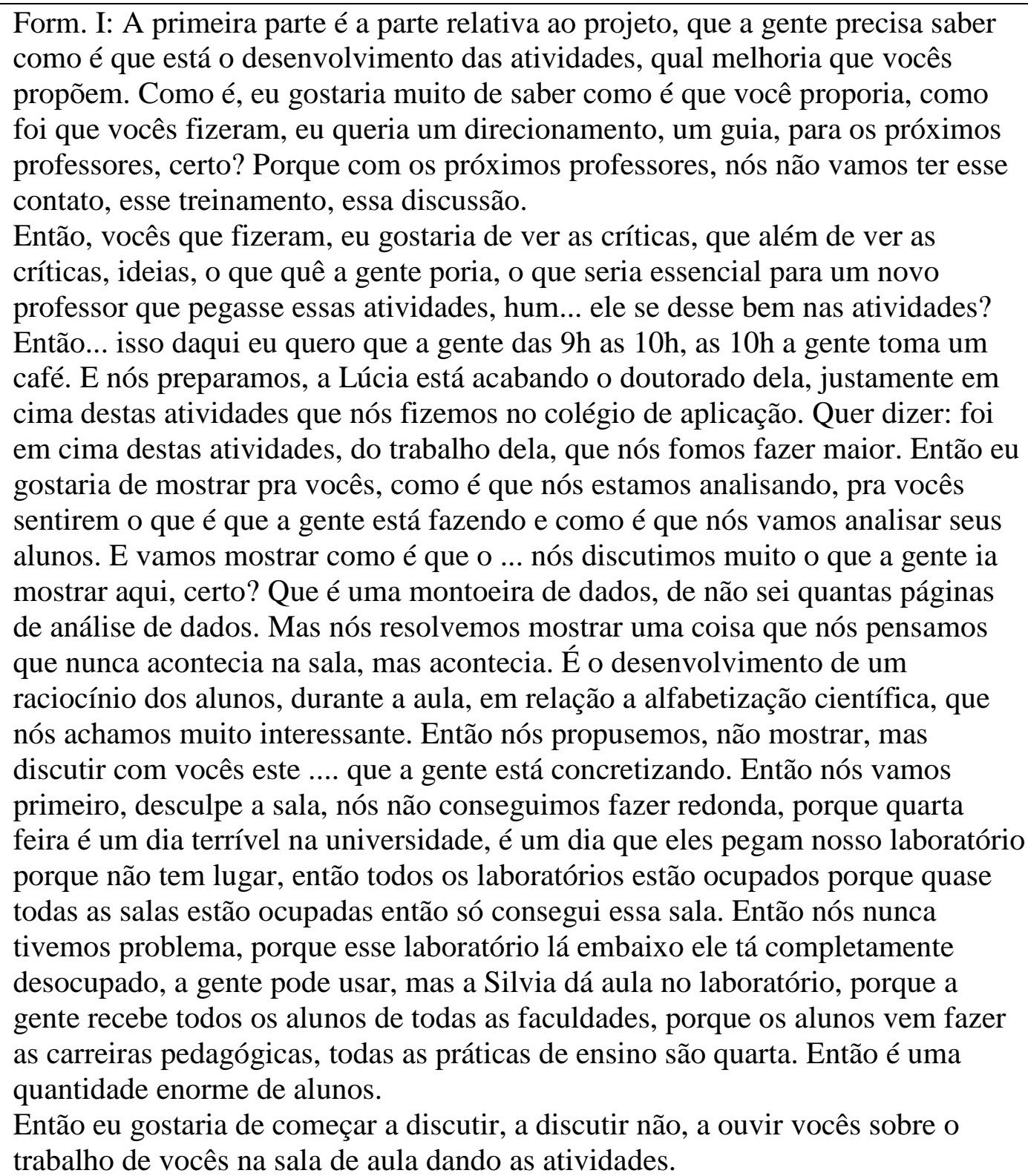 \\
\hline 2 & Silêncio... \\
\hline 3 & $\begin{array}{l}\text { Form. I: Vamos, vamos... Quem é? Verônica... que eu tenho ouvido muito falar, } \\
\text { não é por nada, não mas... é que ela tá gravando o seu, e ela fala da Verônica, que } \\
\text { é a gravação dela... }\end{array}$ \\
\hline 4 & $\begin{array}{l}\text { Verônica: Bom, eu tenho gostado bastante, e uma coisa que eu tenho percebido } \\
\text { nos alunos, que até então tinha uma dificuldade, a minha sala tinha muito, era de } \\
\text { saber estabelecer relação. Que até que eu trabalhava um conteúdo, tentava puxar } \\
\text { aquele conteúdo em outra disciplina e eles ficavam meio assim e eu tenho } \\
\text { percebido que na sequência, acho que a Fernanda também concorda porque ela tá } \\
\text { filmando, ela deve também estar percebendo. Eles falam assim: Ah, que nem } \\
\text { você falou na outra aula, que nem a gente viu em tal texto, eu tenho gostado } \\
\text { muito disso, eles têm buscado referência do que eles já viram, que na minha sala } \\
\text { não era comum. }\end{array}$ \\
\hline 5 & $\begin{array}{l}\text { Form. I: E Verônica, você acha que isso é por causa do conteúdo da atividade, da } \\
\text { relação entre conteúdo, nós procuramos sempre relacionar mesmo. Ou é pela } \\
\text { metodologia que eles falam mais e discutem mais na sala? }\end{array}$ \\
\hline
\end{tabular}




\begin{tabular}{|c|c|}
\hline 6 & $\begin{array}{l}\text { Verônica: Eu acho que são os dois, sinceramente, eu acho que são os dois. Que } \\
\text { eu tenho a prática de sempre tentar relacionar uma aula com a outra, já, eu já } \\
\text { vinha trabalhando isso, mas eu tinha uma dificuldade, que não faziam tanto, e } \\
\text { depois das sequências eles conseguem mais, porque também deu certo de outras } \\
\text { coisas que não estavam na sequência, nos trazermos outras atividades, que não } \\
\text { estavam na sequência, e eles conseguiram, eles tão conseguindo muito isso, né? } \\
\text { Ah, de tal coisa, de tal atividade, eles trazerem isso, e eu achei muito produtivo. }\end{array}$ \\
\hline 7 & Form. I: Ah, ela tá fazendo assim... mas, qual atividade que você deu extra? \\
\hline 8 & $\begin{array}{l}\text { Verônica: Uma que marcou muito foi a questão do meio ambiente, então nós } \\
\text { fomos trabalhar as regiões brasileiras, e lá fala os problemas sobre cada região, } \\
\text { tal. Então, eu levei um texto sobre a região norte, falando dos problemas da } \\
\text { Amazônia, tal, né? E aí, quando a gente foi pra questão do tapiti, que é a questão } \\
\text { do jogo, eles falaram muito isso. Tanto é que quando tem uma perguntinha lá no } \\
\text { texto, né? O que é que está causando o desaparecimento do tapiti? Nossa, eu fiz } \\
\text { uma lista na lousa, falando: são as queimadas, é a interferência humana que o } \\
\text { homem está causando na Amazônia, aí é que nós descobrimos que não, que era a } \\
\text { lebre europeia, aí um aluno foi e falou: "ah, mas foi o homem que trouxe a lebre } \\
\text { europeia", então é interferência humana, que é o que eles tinham falado isso. } \\
\text { Então eu achei isso muito interessante. }\end{array}$ \\
\hline 9 & Form. I: você que tá... eu não sei o seu nome. \\
\hline 10 & $\begin{array}{l}\text { Olga: É, como ela também a gente tenta estabelecer algumas relações e os meus } \\
\text { alunos eu já levei pra matemática. Então, na rodada, nós fizemos gráficos. Eu fiz } \\
\text { gráficos de cada rodada pra eles poderem estar entendendo melhor, os picos, } \\
\text { quando morre, porque que aquele morreu mais, teve mais... teve uma hora que } \\
\text { teve mais jaguatirica do que tapiti, depois teve mais plantas do que.. né? Então } \\
\text { nós fizemos através de gráficos. Então eles também acharam, né? Bem } \\
\text { interessante... }\end{array}$ \\
\hline 11 & Fernanda: É, está lá na atividade... \\
\hline 12 & $\begin{array}{l}\text { Olga: E eu tava fazendo e não tinha dado pra Fernanda gravar, aí ela saiu da sala } \\
\text { da Verônica e foi pra minha. E aí eu estava no meio desse trabalho e aí ela falou: } \\
\text { ah, então eu vou gravar. Não é? Porque era extra, não estava dentro da rotina. }\end{array}$ \\
\hline 13 & Fernanda: Porque a sua sala é mais agitada e eles gostam mais de fazer a coisa. \\
\hline 14 & Olga: É. \\
\hline 15 & Form. I: E eles fizeram os gráficos? \\
\hline 16 & Olga: Fizeram. Cada grupo fez uma rodada... e.... \\
\hline 17 & Form. I: E você tem os gráficos dos alunos? \\
\hline 18 & Olga: Tenho, estão na minha sala. Tá exposto. E aí ela filmou. \\
\hline 19 & Coord.: A gente pode fotografar o gráfico e mandar a foto, de cada gráfico, né? \\
\hline 20 & Form. I: É terceiro ou quarto? \\
\hline 21 & Olga: quarto. \\
\hline 22 & $\begin{array}{l}\text { Form. I: É, as vezes a gente subestima os alunos, né? A gente acha que ... é muito } \\
\text { mais... são capazes de muito mais do que a gente pode e que a gente pensa. São } \\
\text { duas, quem mais que tá? }\end{array}$ \\
\hline 23 & $\begin{array}{l}\text { Mara: Além deles fazerem estas relações com outras atividades, né? O que eu } \\
\text { acho interessante é que eles puxam pra o que eles conhecem no dia a dia deles. } \\
\text { Porque na minha sala o tapiti entrou em extinção na oitava rodada, entendeu? Aí } \\
\text { eles: “Ah, então é por isso que tal animal entra em extinção, que tal animal entrou } \\
\text { em extinção?”. } \\
\text { Eu acho que essa relação que eles fazem com o que eles vêem hoje, hoje na TV, } \\
\text { isso é muito interessante também ,não é? Aí eles percebem porque que aquilo de }\end{array}$ \\
\hline
\end{tabular}




\begin{tabular}{|c|c|}
\hline & $\begin{array}{l}\text { fato acontece. Porque quando ficou tudo planta e tudo jaguatirica e não tinha o } \\
\text { que comer, uma queria, uma jaguatirica queria comer a outra. Tudo bem, come... } \\
\text { e quando só sobrar uma? Vai morrer! } \\
\text { Então, essa relação que eles fazem com o que eles vivem hoje, isso eu achei } \\
\text { interessante. Reporta para o que está acontecendo mesmo, que é a ação do } \\
\text { homem na natureza. }\end{array}$ \\
\hline 24 & Form. I: Pode acontecer com os 3, né? \\
\hline 25 & $\begin{array}{l}\text { Coord.: Uma coisa, essas relações que eles estabelecem, eu acho que a sequência } \\
\text { ajuda, esse conceito que é um conceito geral, do equilíbrio... isso começa lá no } \\
\text { barquinho, como a gente consegue equilibrar as arruelas, até ir mais pra frente } \\
\text { com a .. pra discutir a questão do equilíbrio ambiental. Mas tem uma questão que } \\
\text { é ... na verdade das professoras, que é, toda aula começa rememorando a aula } \\
\text { anterior. } \\
\text { Dizer: "a gente trabalhou isso, trabalhou isso, agora vai trabalhar isso..." } \\
\text { Então, essa ação eu acho que é muito importante e entra como a proposta da } \\
\text { sequência que é, sempre estar fazendo relações, né? }\end{array}$ \\
\hline 26 & Form. I: É alguma coisa que deveria estar num guia para o professor. \\
\hline 27 & $\begin{array}{l}\text { Coord.: é, toda aula começa lembrando, fazendo um esforço pra lembrar do que } \\
\text { já foi estudado no início da aula.... (inaudível)... você percebe que há essa } \\
\text { vontade, que já é um hábito de sempre começar, da professora, de sempre } \\
\text { começar primeiro, né? Principalmente quando tem algum tempo que... uma } \\
\text { semana... eu acho isso interessante, achei interessante. }\end{array}$ \\
\hline 28 & Form. I: Tem mais duas que tão aqui, não tem? Que estão dando as atividades? \\
\hline 29 & Coord.: A Monica, a gente começou a filmar, mas não pegou tanto. \\
\hline 30 & Form. I: Não pegou tanto, mas você está dando? \\
\hline 31 & Coord. e Fernanda: Tá dando \\
\hline 32 & $\begin{array}{l}\text { Form. I: Filmando ou não filmando, o importante é dando... que a gente não tem } \\
\text { gente. }\end{array}$ \\
\hline 33 & Coord.: Tem a Andreza, tem a Iris... \\
\hline 34 & Form. I: Então, eu gostaria de estar vendo a... \\
\hline 35 & $\begin{array}{l}\text { Iris: Eu tenho dado ... é, a minha sala não fez, não conseguiu fazer ainda o jogo } \\
\text { da presa e do predador, então eu estou tomando ciência de algumas atitudes de } \\
\text { alguns resultados com eles aí, né? Que todas as vezes que nós tentamos fazer } \\
\text { juntas, que nós fazemos em duplas, em duas esta atividade, né? Porque eles } \\
\text { ficam, né? (faz gesto com os braços, dizendo que os alunos ficam agitados). } \\
\text { Porque eles estão, eles estão chateados que até agora eles não conseguiram fazer } \\
\text { o jogo, né? Porque eles já tão vendo, eles estão vendo resultados possíveis nas } \\
\text { outras turmas e a minha sala não conseguiu, eu não consegui fazer. Eu tava } \\
\text { comentando com a Mara aqui, que a Verônica deu uma abordagem que ela viu } \\
\text { que as crianças começaram a fazer relações, né? E a Olga em Matemática, então } \\
\text { eu estava comentando com eles, que nós iríamos fazer estes gráficos, e eles } \\
\text { estão... aguardando, então a minha turma ainda está aguardando e eles estão } \\
\text { ansiosos, inclusive, nós iríamos fazer ontem, né? Mas a quadra da nossa escola é } \\
\text { muito requisitada então não conseguimos fazer. É, o espaço tem que ser grandão, } \\
\text { então eu estou ainda nesta expectativa, né? }\end{array}$ \\
\hline 36 & $\begin{array}{l}\text { Form. I: Mas e as atividades antes do jogo? Porque o jogo é o ápice das } \\
\text { atividades, mas e as outras, o que é que você acharam? }\end{array}$ \\
\hline 37 & $\begin{array}{l}\text { Iris: Eu acho assim, como as meninas falaram: eles estabelecem realmente } \\
\text { ligações, eles relacionam, que nós comentamos, por exemplo, em português, }\end{array}$ \\
\hline
\end{tabular}




\begin{tabular}{|c|c|}
\hline & $\begin{array}{l}\text { quando nós entramos em geografia, que eles conseguem assim fazer uma relação. } \\
\text { Quando nós vãos falar sobre o mar, o oceano, né? Eles se lembram, né? “É, } \\
\text { professora, nós comentamos sobre isso.”. Eu acho interessante, que as vezes você } \\
\text { fala e eles não conseguem fazer um elo, uma ligação, relacionar os assuntos, né? } \\
\text { E eu percebo que na minha sala também está acontecendo isso, eles estabelecem } \\
\text { relações entre os assuntos. }\end{array}$ \\
\hline 38 & $\begin{array}{l}\text { Verônica: Eu achei muito interessante, no último texto do mexilhão dourado, que } \\
\text { tem um monte de informações importantes ali, né? E a Vera olhou minha aula } \\
\text { outro dia, né? E até a gente estava comentando ontem. Olha, o relatório rendeu } \\
\text { muito. }\end{array}$ \\
\hline 39 & Form. I: O que? \\
\hline \multirow[t]{2}{*}{40} & $\begin{array}{l}\text { Verônica: O relatório deles, depois do texto do mexilhão dourado, mas saiu } \\
\text { muito pouco do que eu esperava, que é de onde ele veio, o problema que ele está } \\
\text { causando, o que ficou muito claro no relatório, foi a questão do espermatozóide e } \\
\text { do óvulo que se encontram na água, gente... tanto é que eu retomei isso com eles } \\
\text { depois. É que é assim a gente tem o texto que eles... que ele veio na água de } \\
\text { lastro, que ele fica nas hidroelétricas, o problema ecológico que ele está causando } \\
\text { e tudo mais. } \\
\text { Então durante as discussões, eles discutiram muito, falaram, então bem no final, } \\
\text { né, Vera, saiu aquela coisa do espermatozoide. } \\
\text { Porque tem um quadrinho lá, que fala sobre o mexilhão,fala como ele se } \\
\text { reproduz, o tempo de vida dele e tudo mais. E lá explicou assim, que o macho } \\
\text { deixa o espermatozoide na água e a fêmea deixa o óvulo, né? Mas olha, foi o que } \\
\text { saiu no relatório, eles falaram muito pouco da... }\end{array}$ \\
\hline & Risos \\
\hline 41 & $\begin{array}{l}\text { Form. I: E o que você acha, Verônica, o que você acha: tiramos essa coisa do } \\
\text { quadrinho ou não? }\end{array}$ \\
\hline 42 & Verônica: Não.. eu achei interessante que \\
\hline 43 & $\begin{array}{l}\text { Form. I: É? Porque aquele quadrinho está lá só pra... não sei se precisa dar coisas } \\
\text { a mais.... }\end{array}$ \\
\hline 44 & $\begin{array}{l}\text { Verônica: Foi o que eu achei legal, ontem a gente tava estudando uma outra coisa } \\
\text { lá, de língua portuguesa, aí um aluno falou: "é igual aquele do mexilhão dourado, } \\
\text { né?". }\end{array}$ \\
\hline \multirow[t]{2}{*}{45} & $\begin{array}{l}\text { Vera: O que a Verônica tá colocando é interessante, que é próprio desse método } \\
\text { mesmo, né? Você tem que ter lido, o professor tem que ter estudado e visto quais } \\
\text { as possibilidades, porque aí do nada, o menino chega assim e diz: "e o } \\
\text { espermatozoide, o que é esse espermatozoide?". Do nada assim... isso eu acho } \\
\text { interessante.... }\end{array}$ \\
\hline & ACABOU O DVD \\
\hline 46 & $\begin{array}{l}\text { Form. I: Então, esse é um jogo muito tradicional é um jogo que faz até com os } \\
\text { alunos, tem gente que faz isso até no segundo grau, no grau médio, e a gente } \\
\text { queria saber se os alunos podiam fazer. E acho que pode, não pode? }\end{array}$ \\
\hline 47 & Professoras: pode. \\
\hline 48 & Form. I: Pode... e dá muito... \\
\hline 49 & Coord.: Muito legal. \\
\hline 50 & $\begin{array}{l}\text { Form. I: É, muito legal e não vai atrapalhar se quiser fazer depois, } 10 \text { anos depois } \\
\text { se quiser. Quem mais gostaria de ver? E tem gente fazendo a outra sequência. }\end{array}$ \\
\hline 51 & $\begin{array}{l}\text { Coord.: Nós estamos fazendo agora o submarino com os terceiros anos, como as } \\
\text { meninas falaram . E está indo muito bem, os terceiros anos... }\end{array}$ \\
\hline 52 & Form. I: eu gostaria de saber, nós estamos refazendo aqui na escola de aplicação, \\
\hline
\end{tabular}




\begin{tabular}{|c|c|}
\hline & $\begin{array}{l}\text { mas não é pra badalar, mas vocês são mais criativas. Porque lá é muito } \\
\text { padronizado, nada pode sair das coisas programadas e isso atrapalha. Atrapalha, } \\
\text { já tem duas professoras na sala, se entra na aula de geografia... }\end{array}$ \\
\hline 53 & Coord.: Alguém poderia falar, né? Tem que falar... \\
\hline 54 & Mara: Está tudo (fazendo sinal de círculo com a mão)... trabalhando junto. \\
\hline 55 & $\begin{array}{l}\text { Olga: Aí foi Geografia, História, e circula tudo, meio ambiente, mapa mundi, e aí } \\
\text { nós fomos pras olimpíadas e aí teve o mapa mundi lá que a gente tá criando e } \\
\text { estamos fazendo em uma parede, um mapa que coloca o mar, e aí ele está vendo } \\
\text { o oceano, a parte dos oceanos e aí já entra as olimpíadas e eles estão vendo onde } \\
\text { está Pequim, e tal... Trabalho de perto, né? Uma coisa só... uma coisa leva a } \\
\text { outra. }\end{array}$ \\
\hline 56 & $\begin{array}{l}\text { Sofia: E a possibilidade também que o laboratório de informática também } \\
\text { proporciona, as pesquisas na internet. Então tudo o que eu vou fazer, porque eu } \\
\text { fiz no terceiro, o submarino, que foi a primeira sala a fazer, né? } \\
\text { Então, eles tinham muitas pesquisas, depois que a gente fez a experiência a gente } \\
\text { foi pesquisar. Deixa eu falar minha experiência um pouquinho, que teve algo que } \\
\text { me surpreendeu. Eu acho que até subestimei um pouco os meus alunos, porque } \\
\text { eles pegam muito rápido. Muito rápido mesmo.. pelo o que a Coord. disse acho } \\
\text { que eles foram mais rápido até que o é que os outros... uma coisa que eu percebi } \\
\text { é que eles sabem o que eles fazem, como funciona, o que é que tem que fazer pro } \\
\text { submarino não afundar, subir, flutuar, então eles conseguem pegar o porque que } \\
\text { isso aconteceu, demora um pouco mais... inclusive o relatório, eu até vou refazer } \\
\text { o relatório com eles, porque foi meu primeiro relatório, ficou um pouco falho. } \\
\text { Eles falavam: "eu assoprei, eu suguei”, mas não ficou muito claro o porque que } \\
\text { isso acontecia, isso ficou claro, não é Coord.? Eles até disseram mas na hora de } \\
\text { por no papel ficou meio complicado. }\end{array}$ \\
\hline 57 & $\begin{array}{l}\text { Form. I: Filha, esse é um fenômeno que nós estamos estudando. Não são os seus } \\
\text { alunos, são todos.. }\end{array}$ \\
\hline 58 & SOFIA: É, eu sei que é geral... \\
\hline 59 & Form. I: a gente só descreve, mas na hora de por o porquê, a gente não coloca... \\
\hline 60 & SOFIA: É que tem um bloqueio... \\
\hline 61 & $\begin{array}{l}\text { Form. I: Eu acho que não é bloqueio, é uma coisa mais... eu não sou psicóloga, } \\
\text { não sou nada, mas nós estamos com uma pesquisa nesta direção, que eu também } \\
\text { gostaria de discutir com vocês, sobre a pesquisa, pois nós estamos também } \\
\text { pesquisando nesta direção, vendo que isso é um.... no trabalho, tem um artigo da } \\
\text { Carla, que ela escreveu do mestrado dela, e ela chegou na mesma coisa: dos } 30 \\
\text { relatórios que nós estudamos, nós estudamos } 10 \text { crianças em três atividades. } \\
\text { Então são 30. Dos } 30 \text { acho que não tem } 3 \text { que chega ao porquê. }\end{array}$ \\
\hline 62 & SOFIA: Engraçado é que eles sabem... eu sei que eles entenderam, \\
\hline 63 & Form. I: sabem, sabem.. \\
\hline 64 & $\begin{array}{l}\text { SOFIA: Eles falaram muito no laboratório, mas na hora de colocar no papel eu } \\
\text { percebi que não... }\end{array}$ \\
\hline 65 & Form. I: Não, não coloca. Não coloca quando é assim, espontâneo, né? \\
\hline 66 & SOFIA: Eles até fazem, eu não sei o que que... \\
\hline 67 & $\begin{array}{l}\text { Form. I: Agora, eu gostaria de ver se você depois de fazer espontâneo, depois de } \\
\text { perguntar o porque, se a professora está mandando se eles poriam o porquê. Quer } \\
\text { dizer: essa coisa é uma coisa importante, de fato é uma coisa importante pra } \\
\text { gente saber, pra gente discutir o papel do professor. }\end{array}$ \\
\hline 68 & $\begin{array}{l}\text { SOFIA: É, inclusive eu falei pra ela que eu vou fazer, que eu sei que eles sabem, } \\
\text { mas eu quero que eles escrevam, e da cabecinha deles. E não adianta fazer um }\end{array}$ \\
\hline
\end{tabular}




\begin{tabular}{|c|c|}
\hline & $\begin{array}{l}\text { texto coletivo, porque eu sei que um da sala vai fazer. Um da sala vai falar: } \\
\text { "porque, ai, professora, o ar, tal..." eu sei que ele vai falar. }\end{array}$ \\
\hline 69 & Form. I: E ele fala! Mas ele fala! Será que ele escreve? \\
\hline 70 & SOFIA: Talvez ele até escreva, mas eu quero que os outros cheguem... \\
\hline 71 & Form. I: Que os outros cheguem, é... \\
\hline 72 & $\begin{array}{l}\text { SOFIA: Um meu escreveu, que é o que até se destaca na hora da fala, mas ele vai } \\
\text { direcionar os outros, eu queria que os outros também escrevessem. Primeiro a } \\
\text { hipótese deles, o porque deles, cada um individualmente, pra depois fazer o texto } \\
\text { coletivo. }\end{array}$ \\
\hline 73 & $\begin{array}{l}\text { Coord.: Na sala da Laura, né, assim que ela terminou o relatório, ela me passou } \\
\text { todos, aí eu fui analisar, quantos Laura que tinha no total? } 38 ?\end{array}$ \\
\hline 74 & Laura: Não, faltaram aquele dia, tinham 28. \\
\hline 75 & Coord.: Então de 28, 3 falaram o porquê. \\
\hline 76 & Form. I: Pois é. É um $10 \%$. \\
\hline 77 & Coord.: Mas explicam direitinho. É. \\
\hline 78 & $\begin{array}{l}\text { Form. I: Mas nós não podemos dar, numa escola, quando a gente manda escrever, } \\
\text { tem... mas a gente tem que direcionar... algum direcionamento pra eles chegarem } \\
\text { no porquê. Porque é essa, a.... porque é } 10 \% \text { que escreve o porque, e não é } 10 \% \\
\text { que fala , é muito mais. A gente sabe que é muito mais na sala de aula. }\end{array}$ \\
\hline \multirow[t]{7}{*}{79} & $\begin{array}{l}\text { Coord.: E nós temos uma prática, que é assim: antes da escrita do relatório, a } \\
\text { professora pergunta: qual o problema que nós resolvemos? Como, por que? É } \\
\text { uma escrita espontânea mas é uma escrita discutida antes, né? }\end{array}$ \\
\hline & $\begin{array}{l}\text { SOFIA: Porque antes de subir para o laboratório, eu propus para os meus alunos: } \\
\text { a aula que eu dei lá, né? Eu falei: "olha, hoje nós vamos resolver um problema no } \\
\text { laboratório de ciências, nós vamos dar o material pra vocês", elenquei o material, } \\
\text { e "eu quero que vocês me ajudem a fazer o submarino subir e descer", nem usei } \\
\text { as palavras, usei subir e descer... Como é o submarino? Como é que funciona o } \\
\text { submarino? Aí eles fizeram num papel individualmente e eles já tinham um } \\
\text { problema pra resolver. Então eles sabiam o que tinham que fazer, então é muito } \\
\text { engraçado, porque o grupo de consegue é uma felicidade. E tem os que colam, } \\
\text { né? Os grupos que vão lá, como é que é que você fez? }\end{array}$ \\
\hline & $\begin{array}{l}\text { Form. I: Mas é importante, Se ele aprende com o professor, ele não aprende com } \\
\text { o aluno também? }\end{array}$ \\
\hline & SOFIA: Mas eu achei que demoraria mais tempo... \\
\hline & $\begin{array}{l}\text { Vera: Eu acho que é isso: quando você vai falar algo verbalmente que não tem } \\
\text { tanto compromisso, mesmo que você sabe que está sendo gravado, acho que não } \\
\text { temos um compromisso... Então você vai falando e a não ser que não tenha muita } \\
\text { lógica, aí você acaba falando assim: ah, porque sim ou porque não, você acaba } \\
\text { matando assim, porque sim ou porque não. Agora dá trabalho, você transpor essa } \\
\text { argumentação, verbalmente por escrito. É muito trabalhoso. }\end{array}$ \\
\hline & $\begin{array}{l}\text { Form. I: Mas é isso mesmo! A gente já tem isso escrito e coisa... a fala, é muito } \\
\text { mais aberta, muito mais espontânea, não tenta obrigação de lógica, tanto é que } \\
\text { quando a gente vai degravar, a gente mesmo vê: “meu Deus, eu falei isso? Eu não } \\
\text { completei a frase, eu completei depois", não é? Não sei se vocês já tiraram } \\
\text { coisa... quer dizer: a gente não tem uma obrigação com a lógica, a parte escrita é } \\
\text { muito mais estruturada... }\end{array}$ \\
\hline & $\begin{array}{l}\text { Vera: Talvez aí o trabalho com a língua, porque é depois quando você vai poder, } \\
\text { junto com a criança, estabelecer alguma estrutura pra que ele saiba como limpar } \\
\text { o texto. Como revisar o texto, mesmo que ele escreve particulado, na hora de } \\
\text { revisar, ele fala assim: "você pode revisar o meu trabalho?" e dá trabalho. }\end{array}$ \\
\hline
\end{tabular}




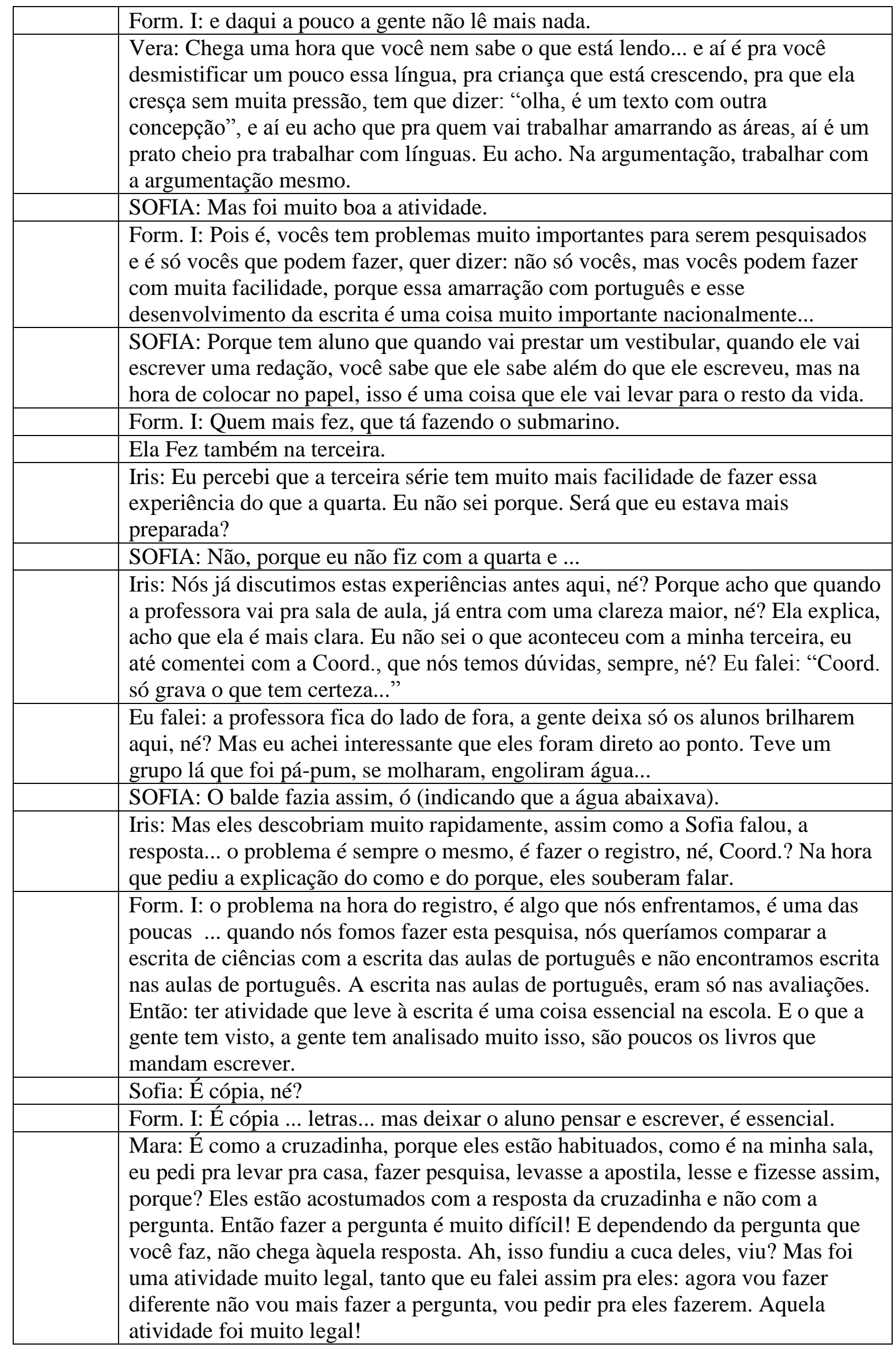




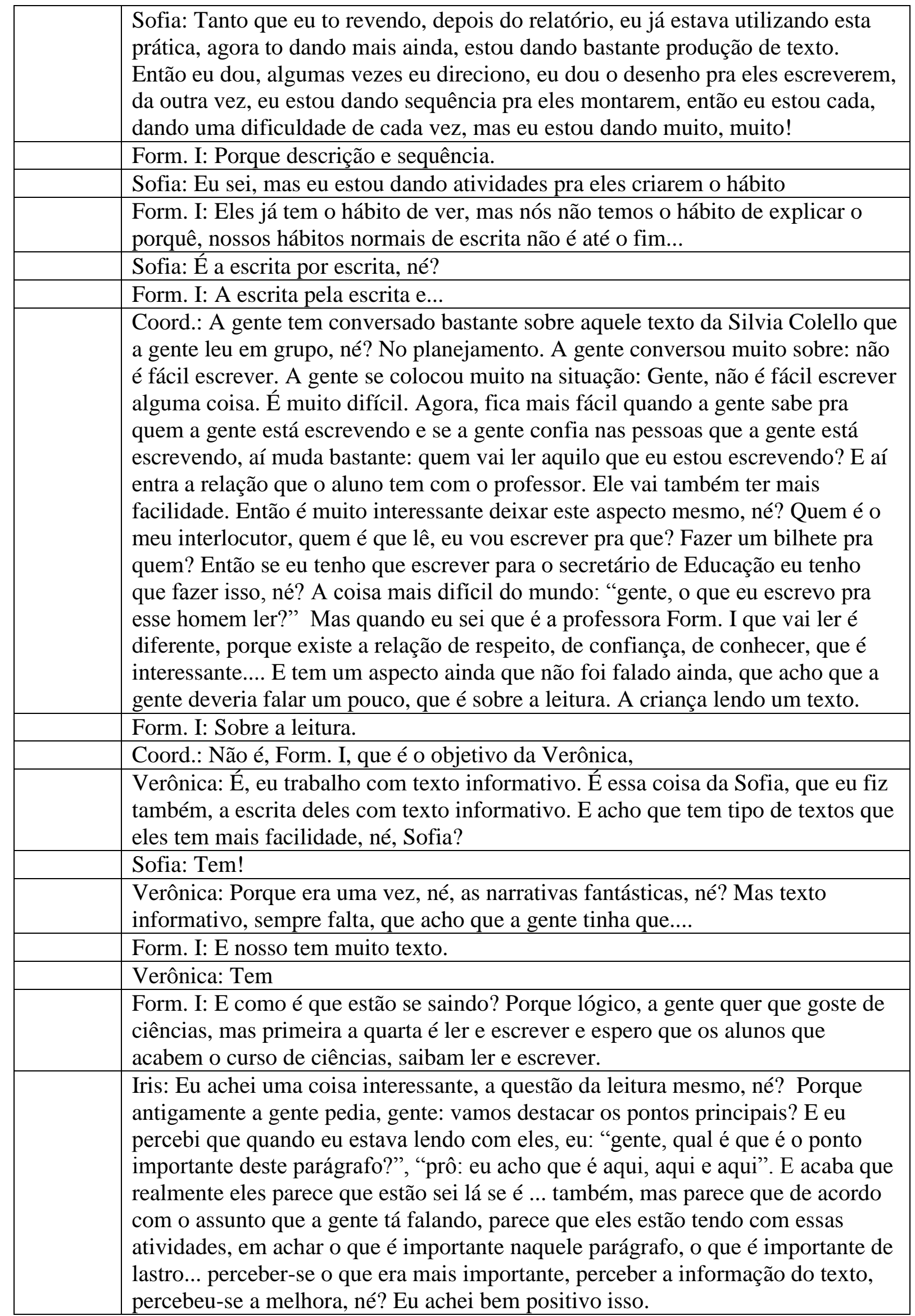

